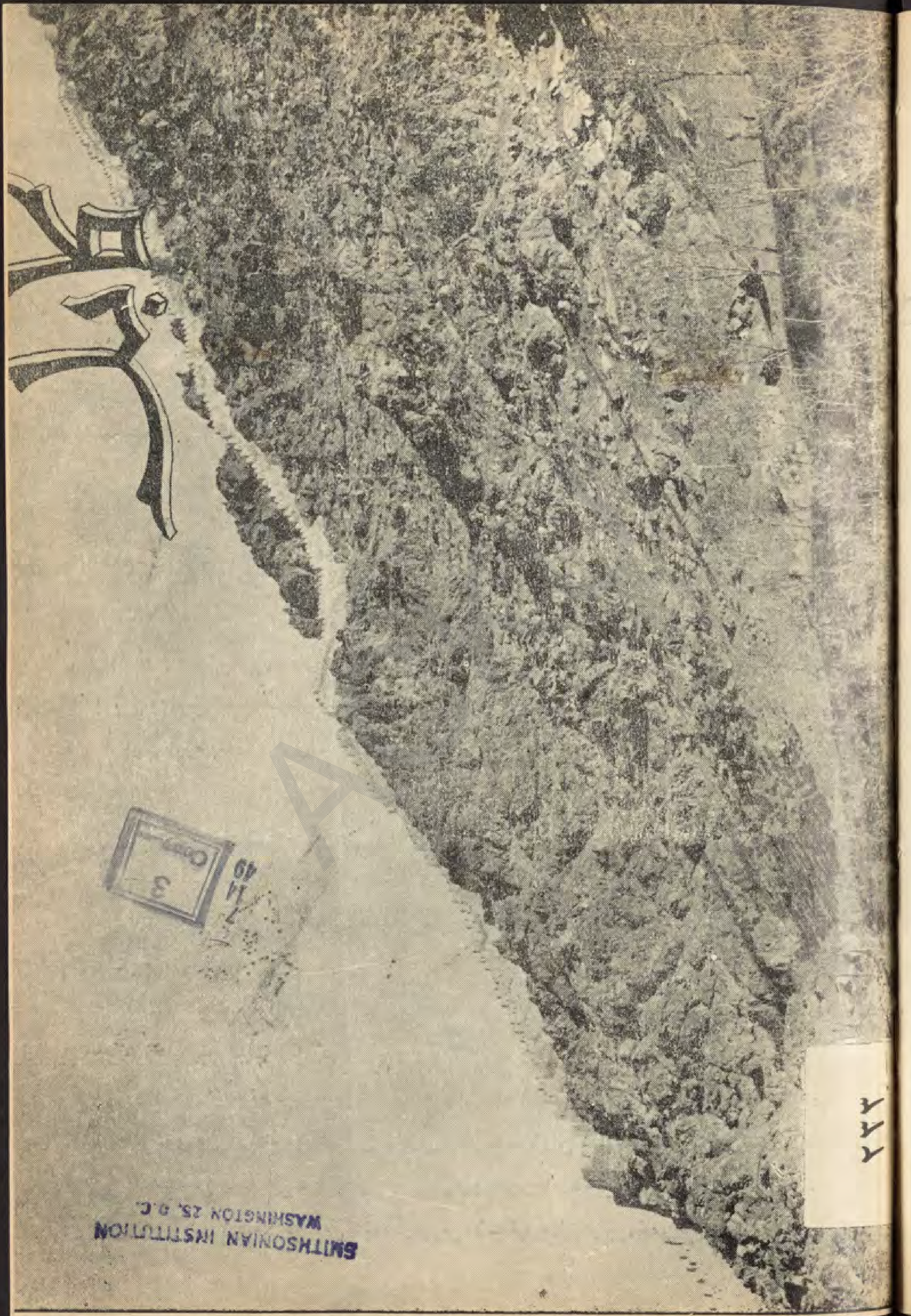




\section{$\cos _{0}, 4 \div 0$;}

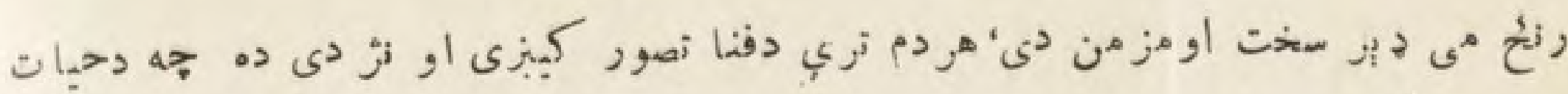
سر م وداع

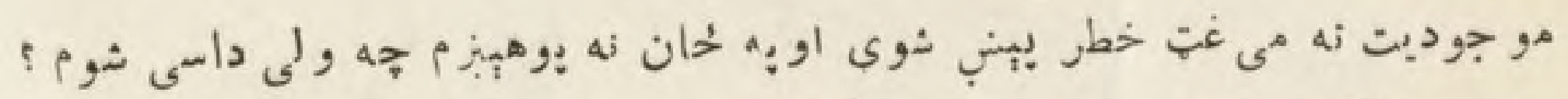

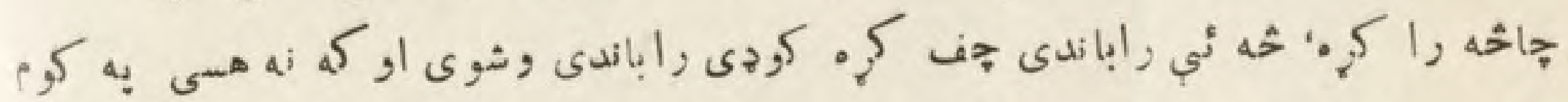
ج.... جسها نى مرض اخته شوم؟؟؟

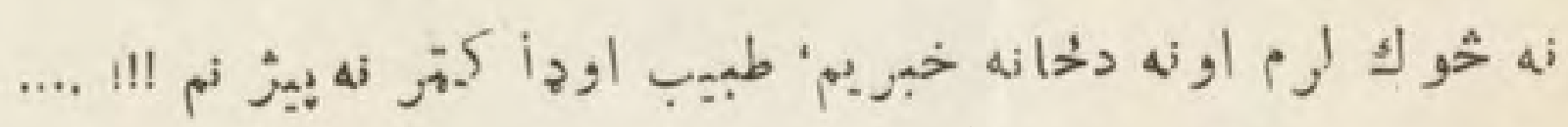
s ** * *

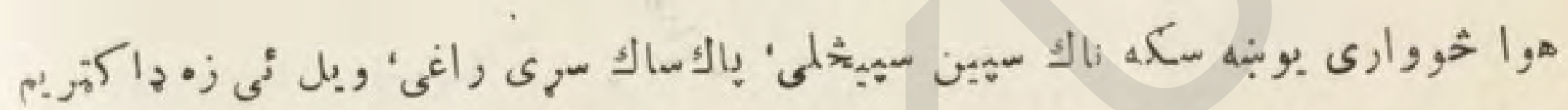

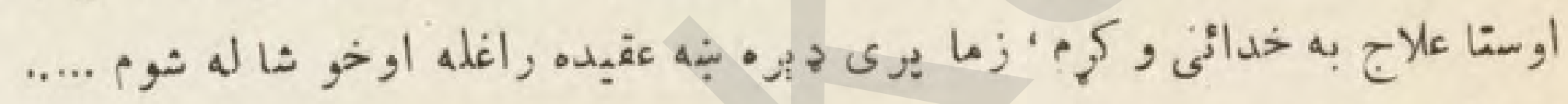

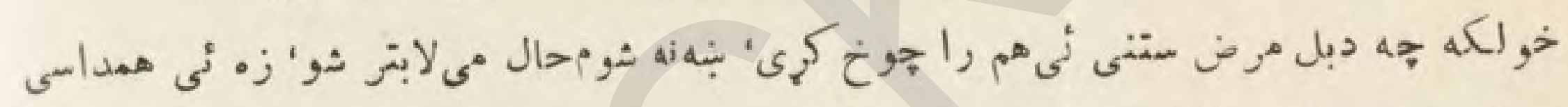

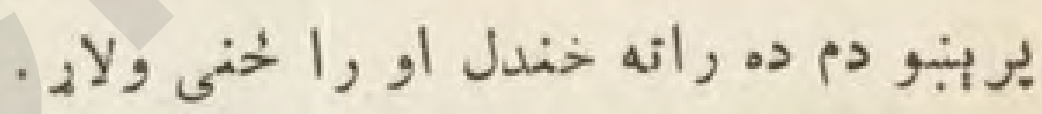

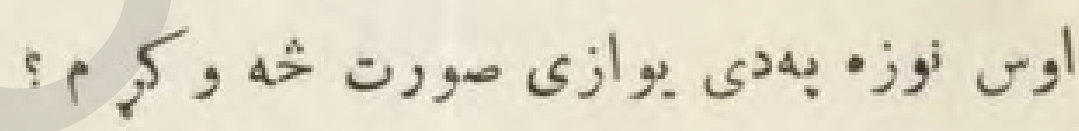
* * *

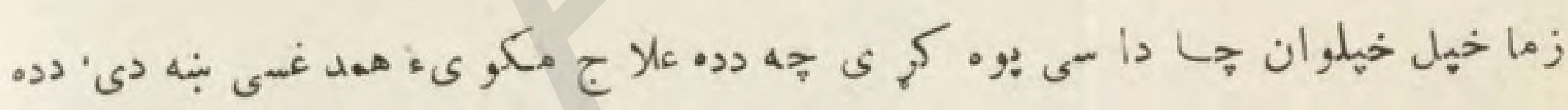

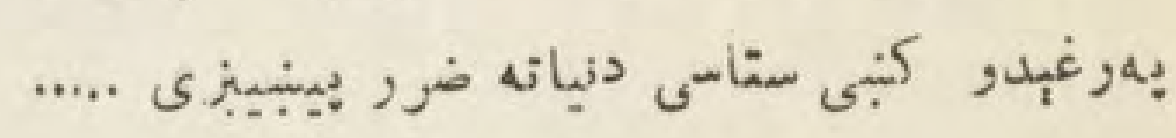

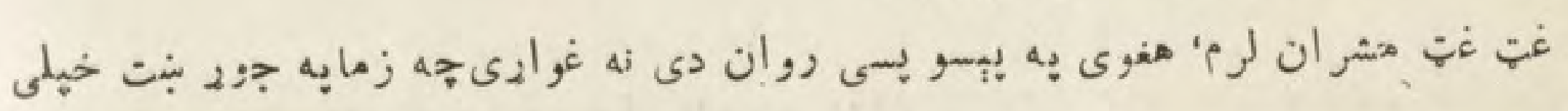

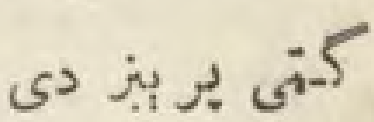

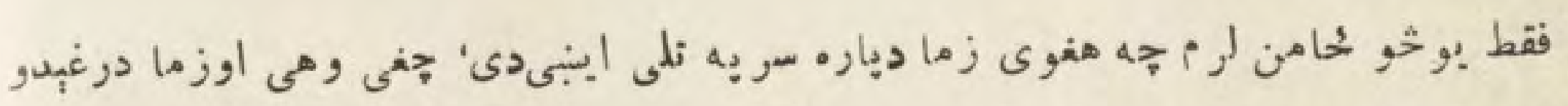

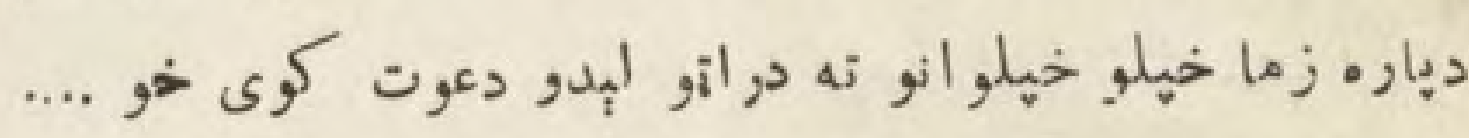

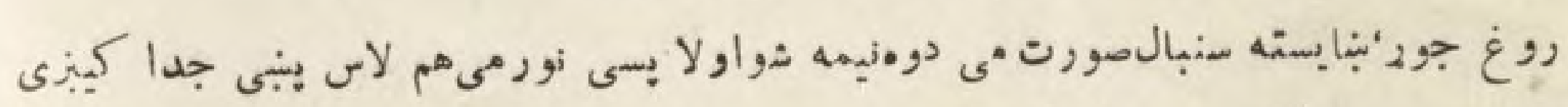

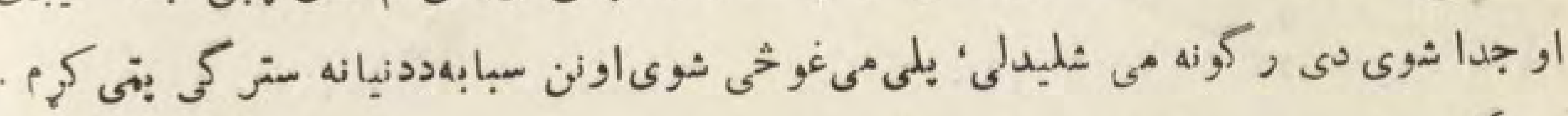

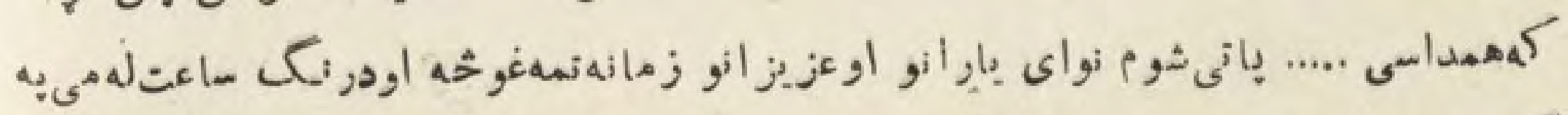

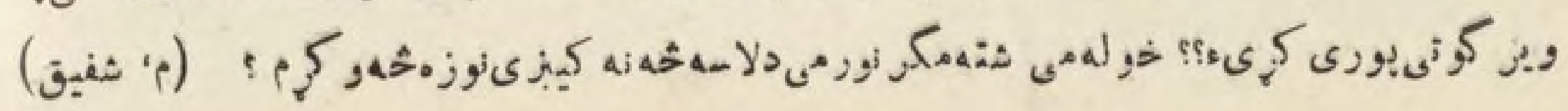




$$
\begin{aligned}
& (45+r) \quad \text { 19:9 }(r \cdot), g: 00
\end{aligned}
$$

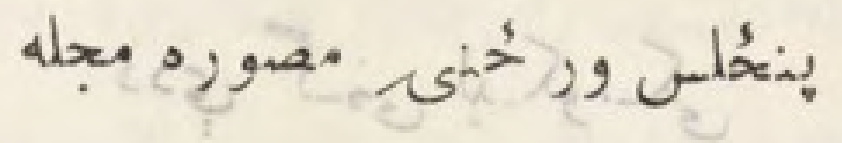

$$
\begin{aligned}
& \text { 药 }
\end{aligned}
$$

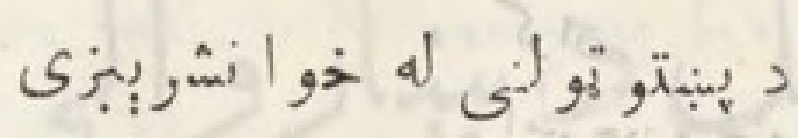

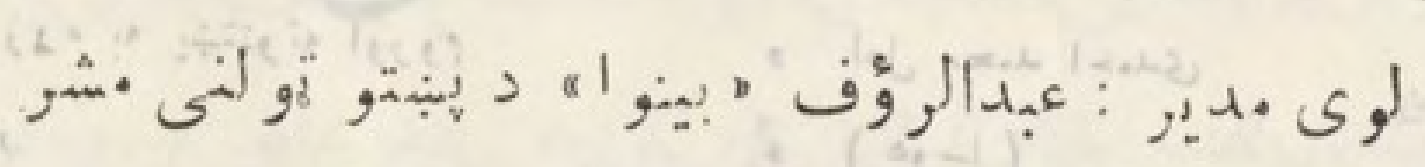

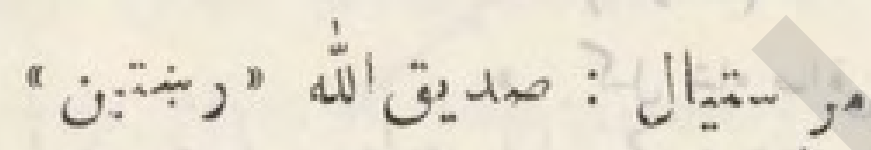

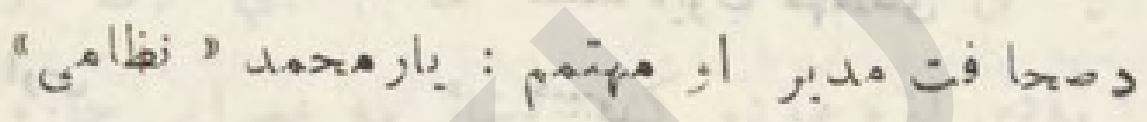

$$
\begin{aligned}
& \text { - } 1, \text {, } \\
& \text { 4) }
\end{aligned}
$$

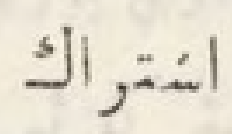

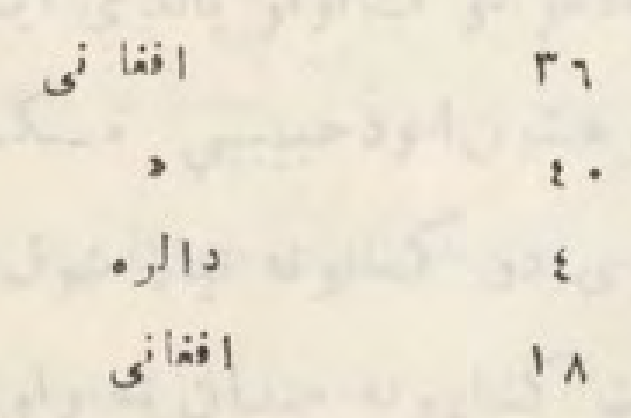

$$
\begin{aligned}
& 154 \\
& \text { i } 5 \text { गु } \\
& \text { ' }
\end{aligned}
$$

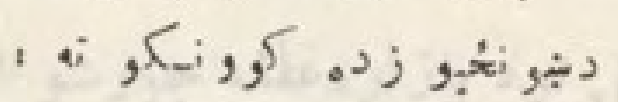




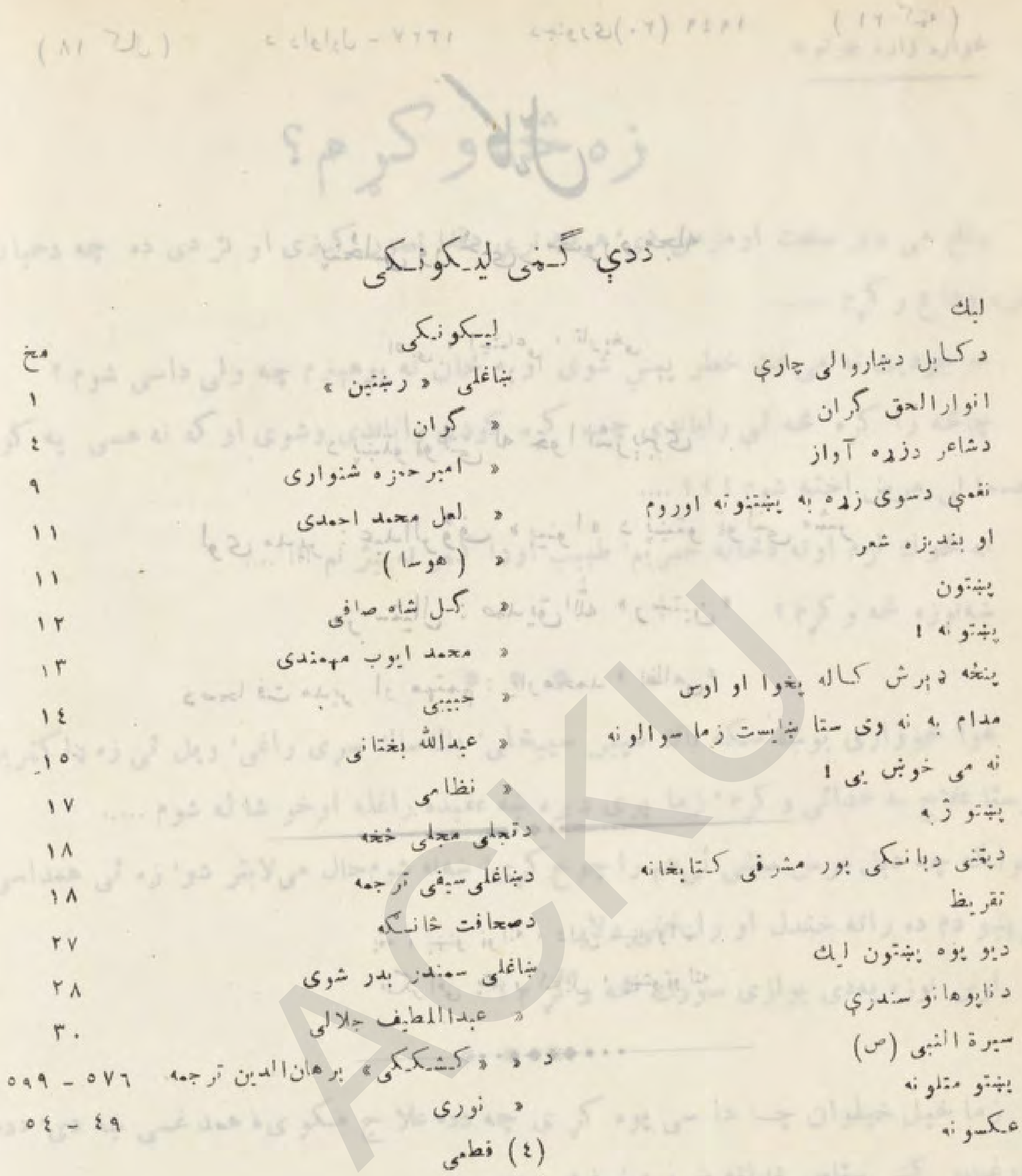




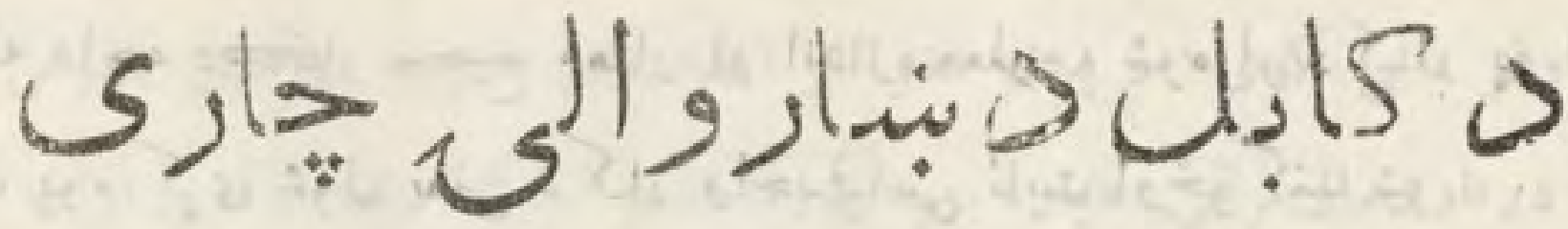

مبريق

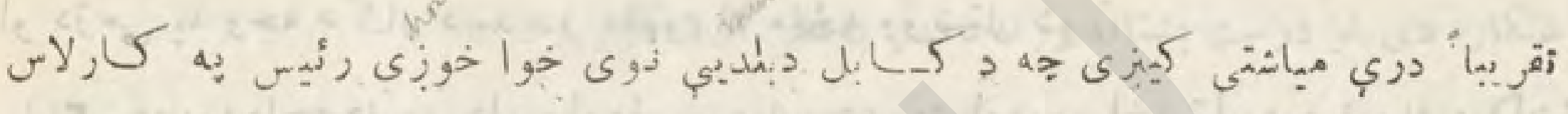

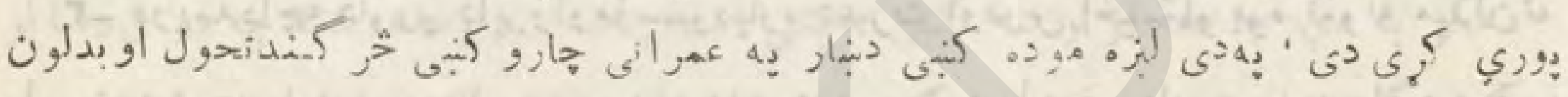

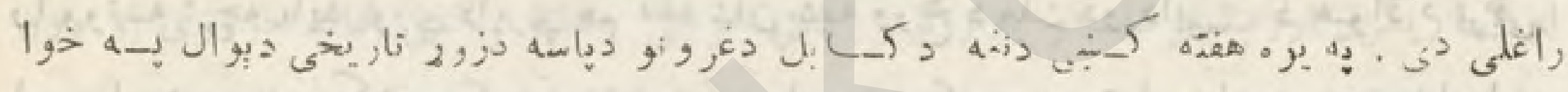

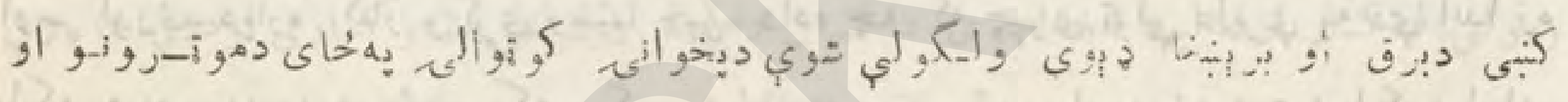

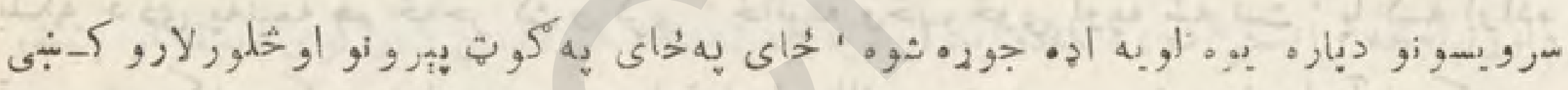

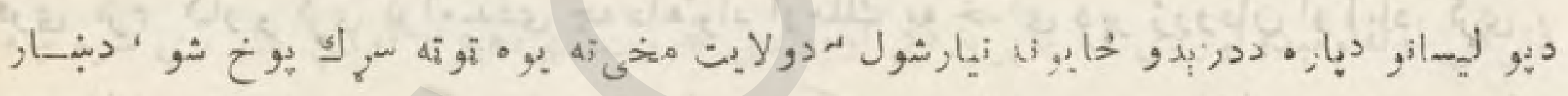

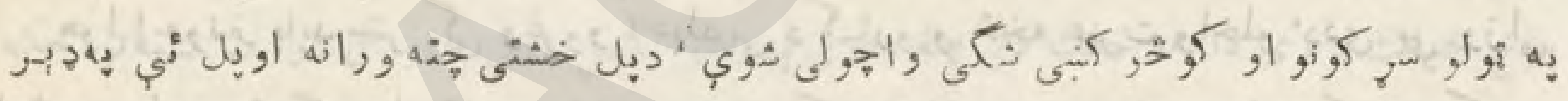

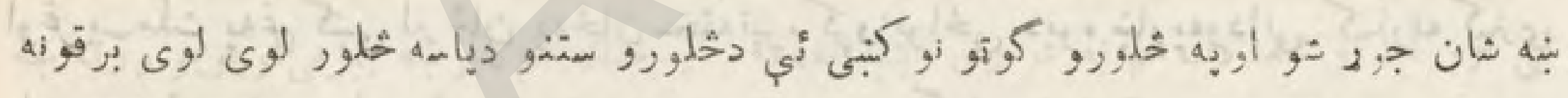

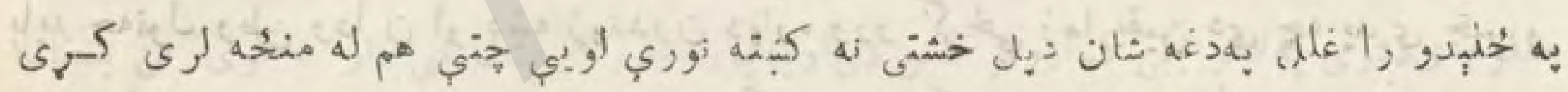

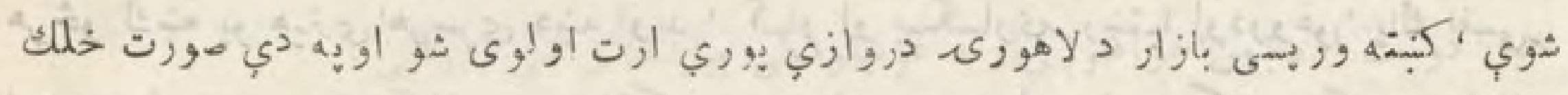

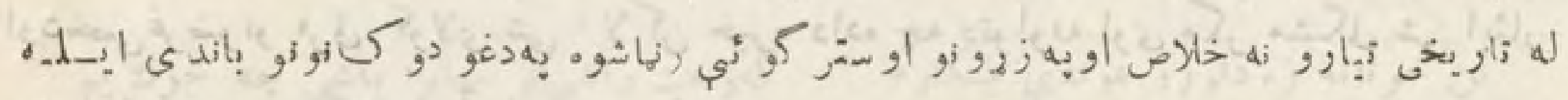

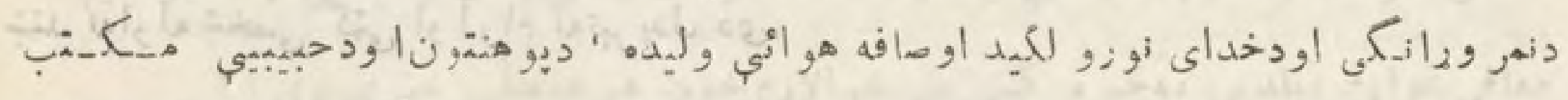

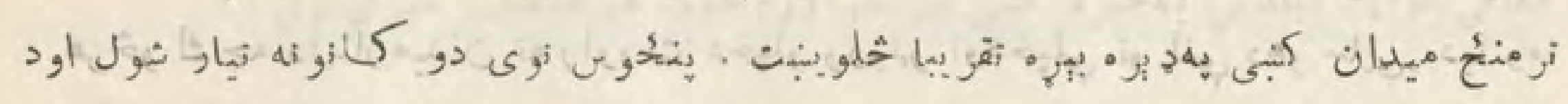

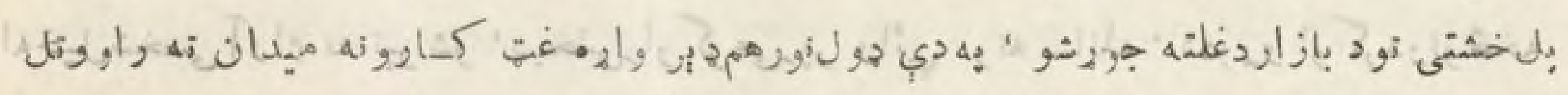

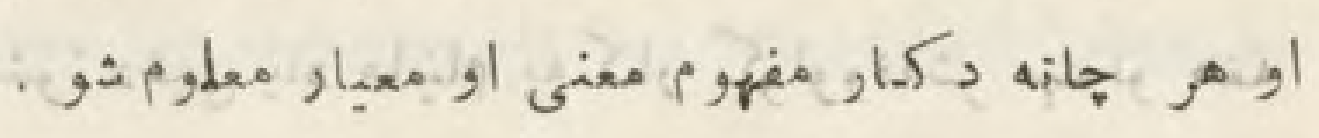

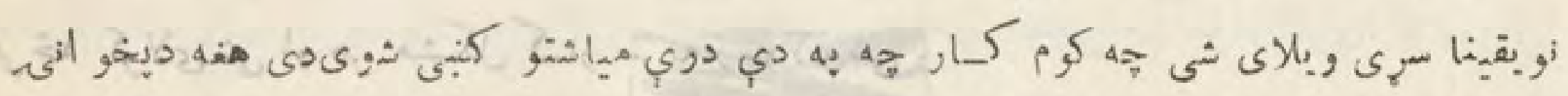

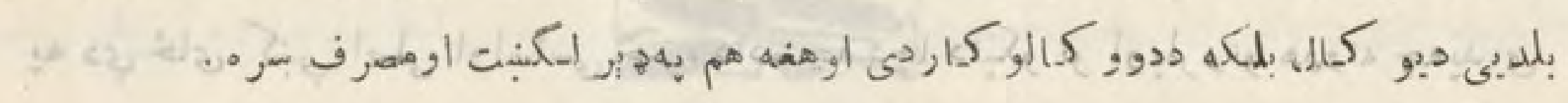




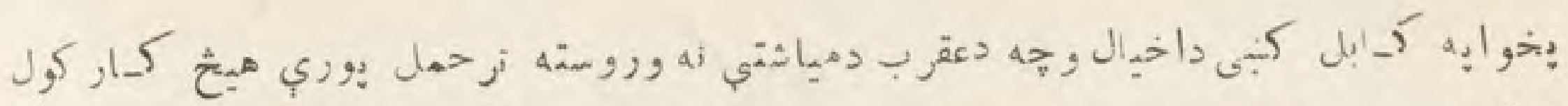

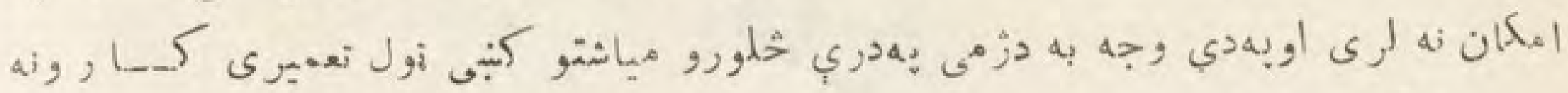

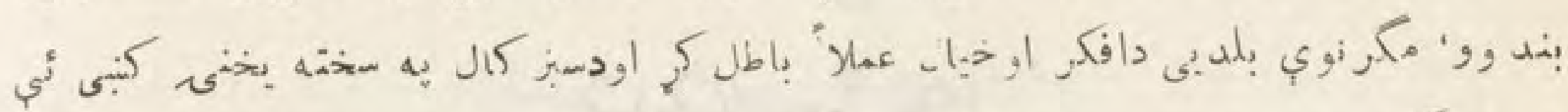

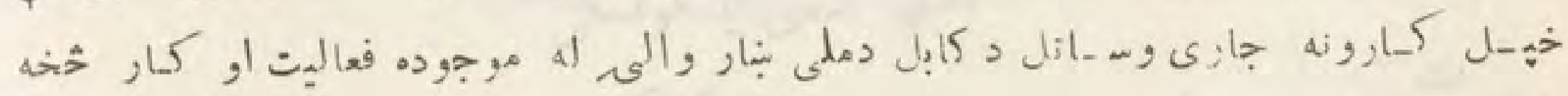

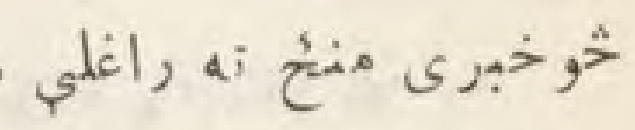

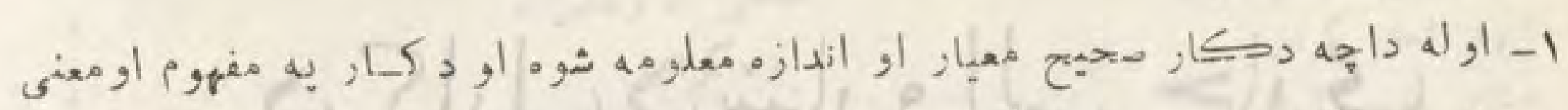

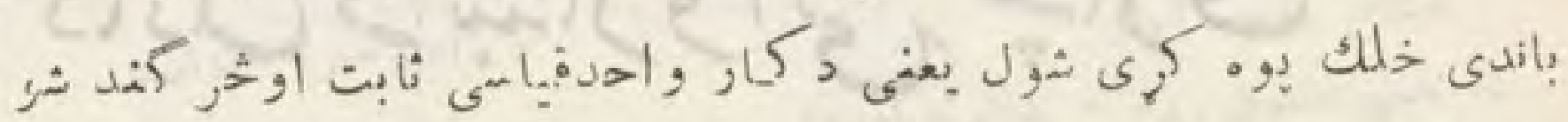

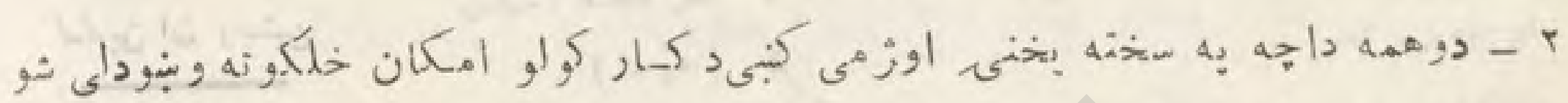

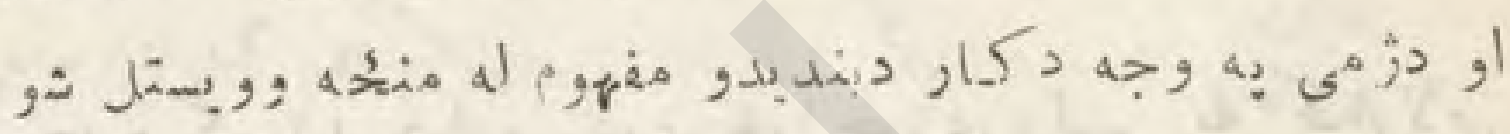

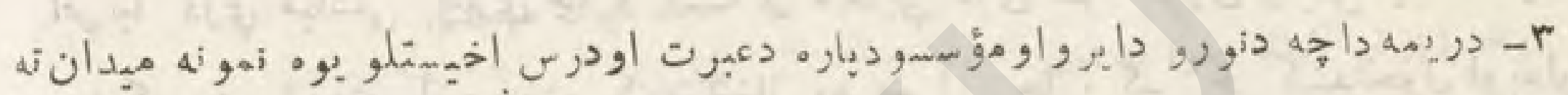

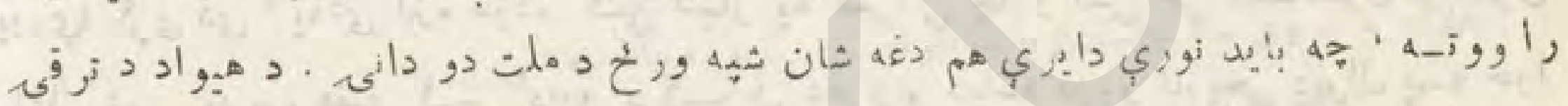

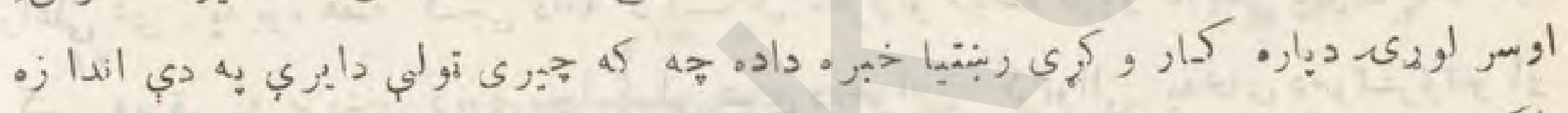

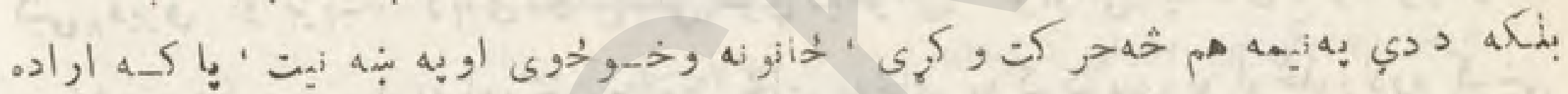

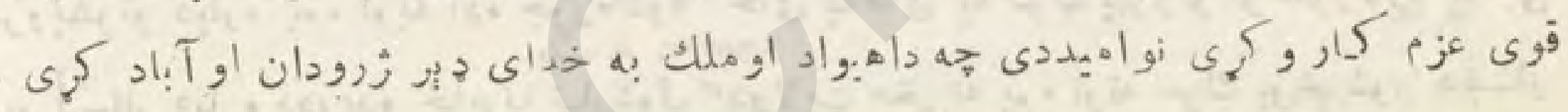

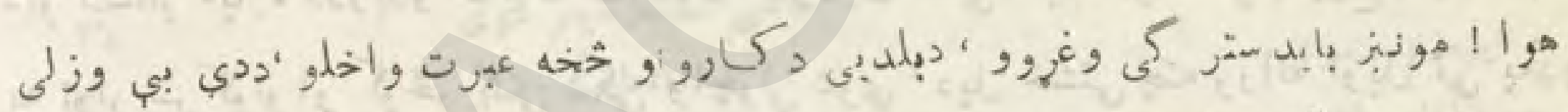

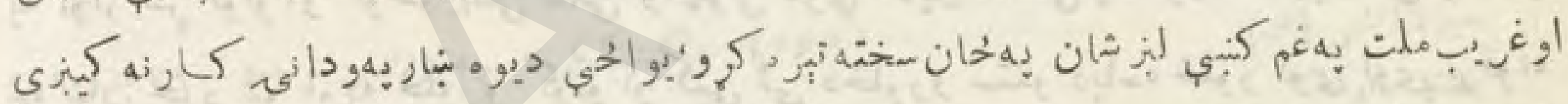

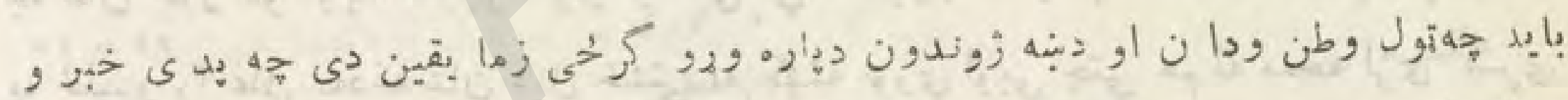

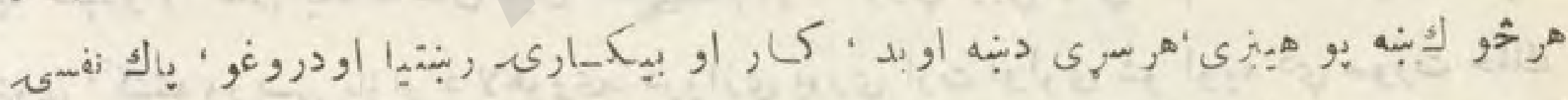

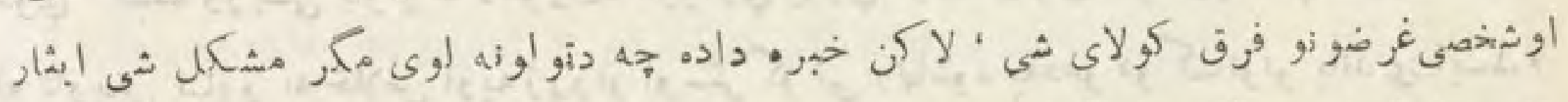

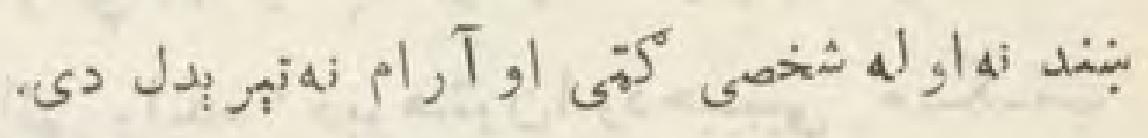

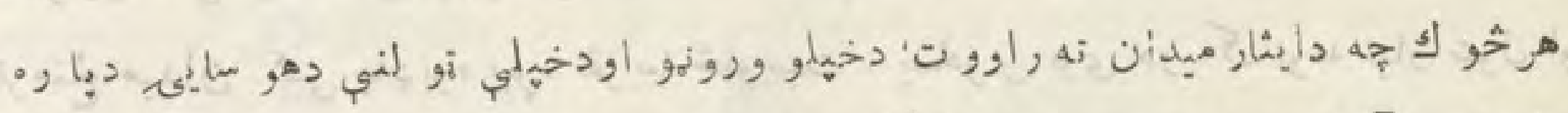

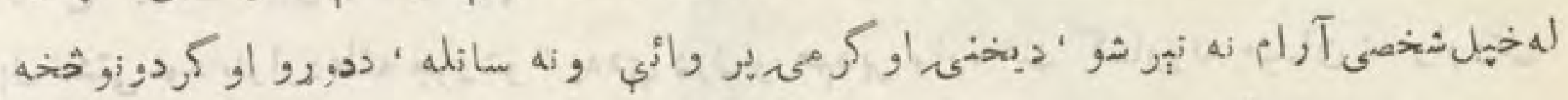

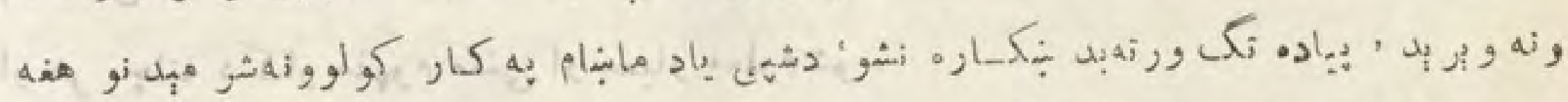

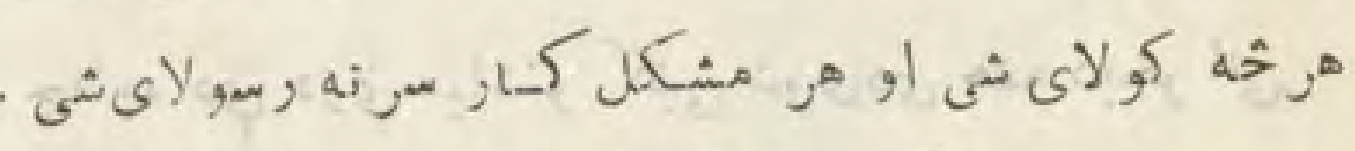

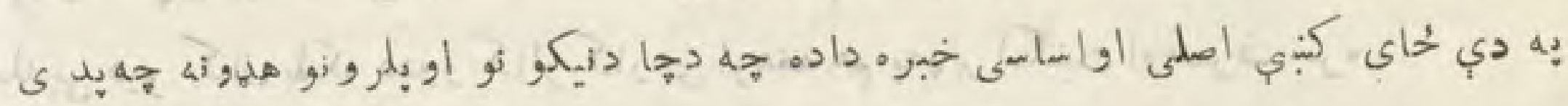




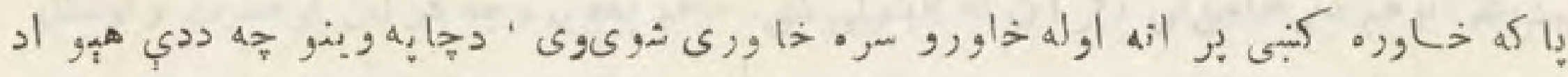

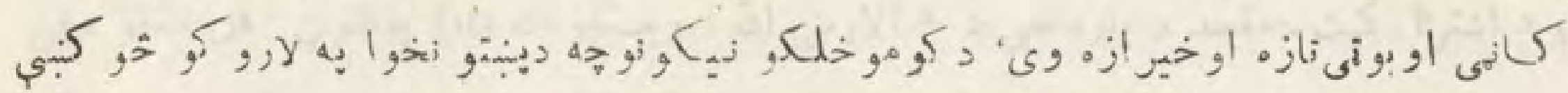

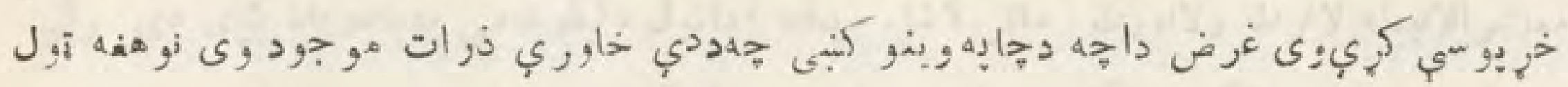

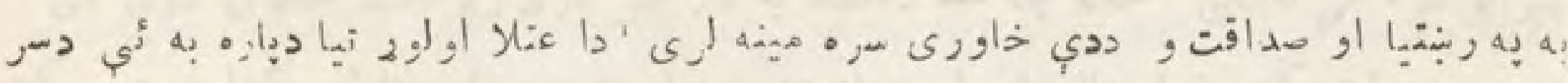

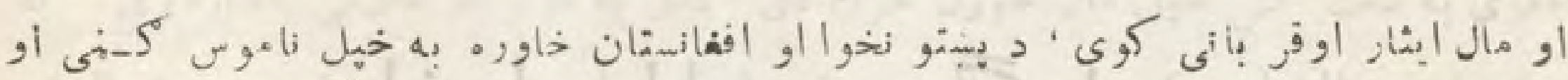

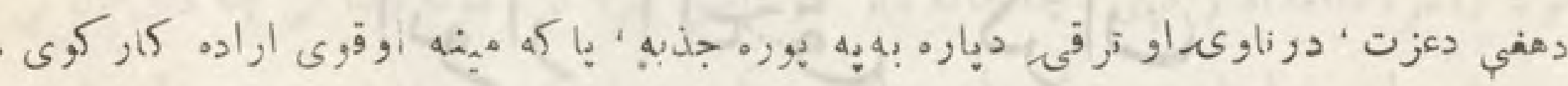

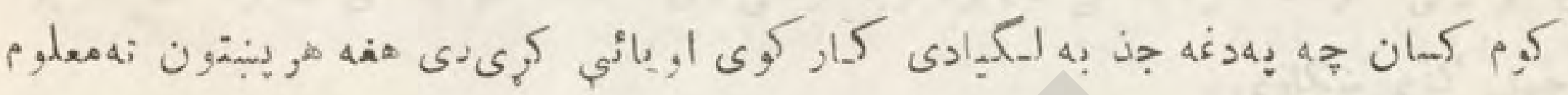

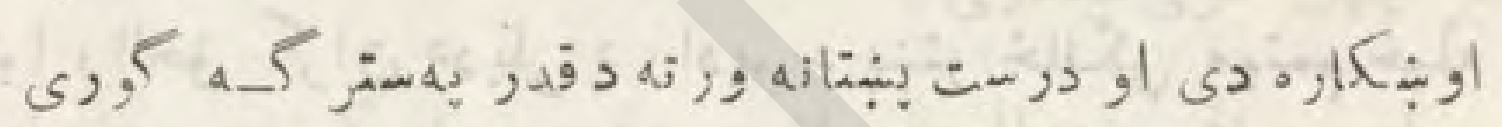

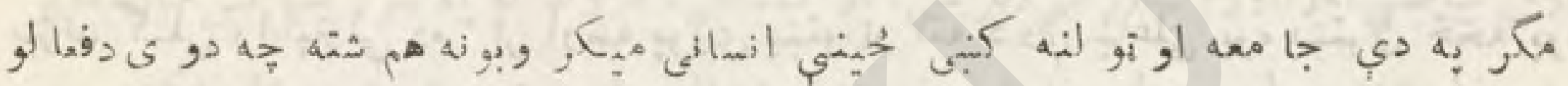

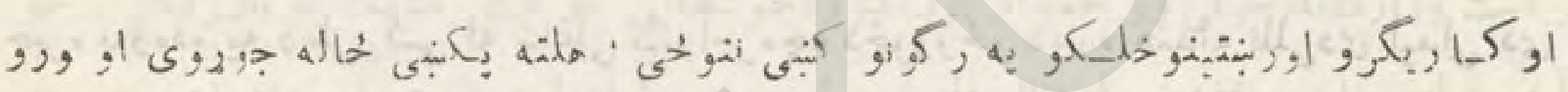

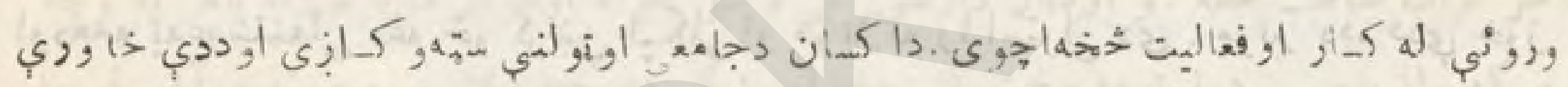
دوله

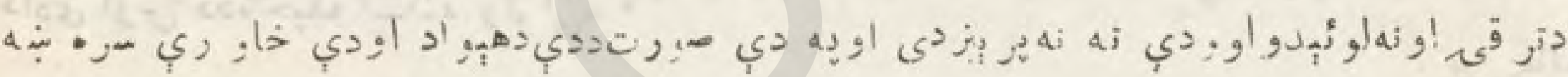

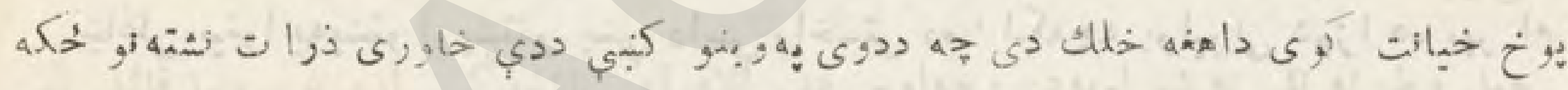

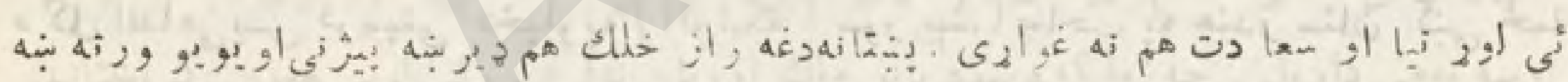

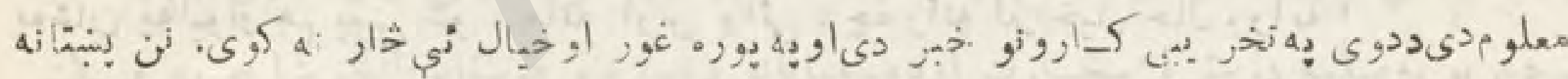

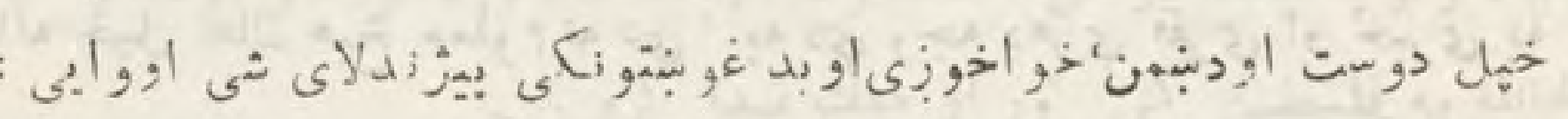

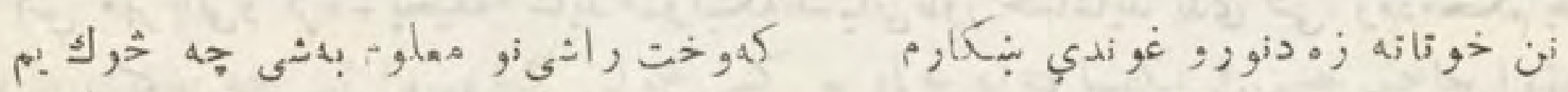

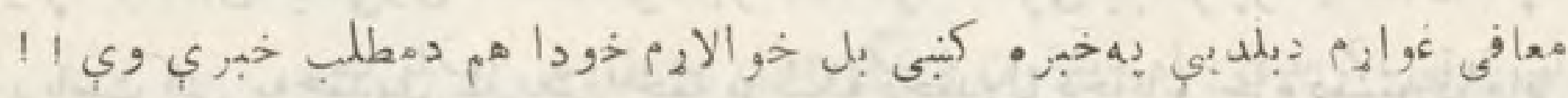

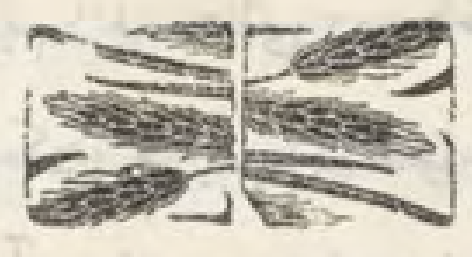




\section{انوار إن}

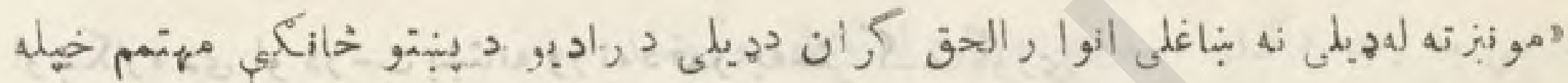

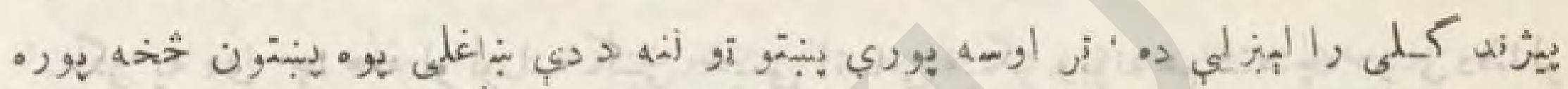

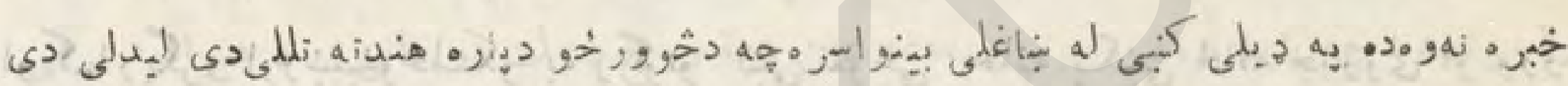

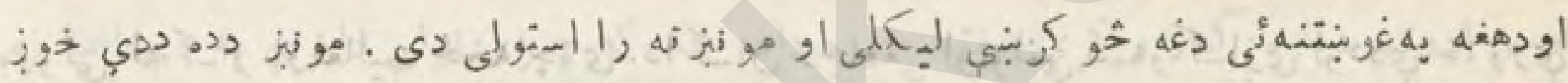

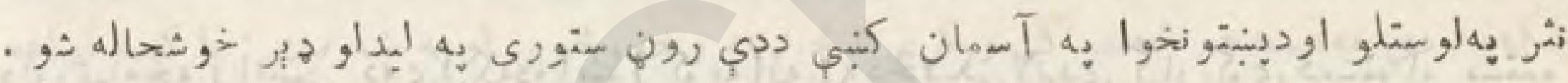
دادى اوس

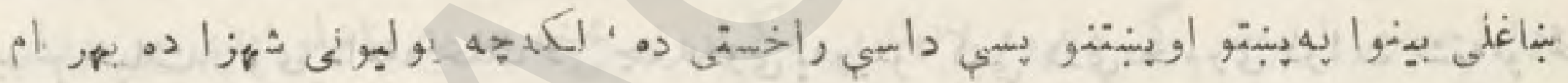

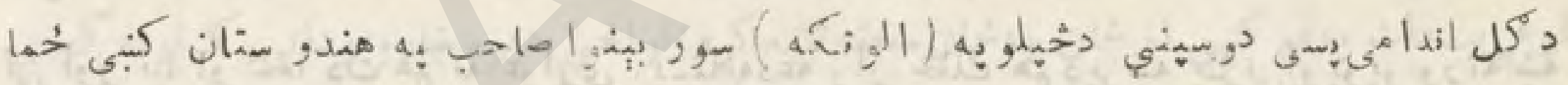

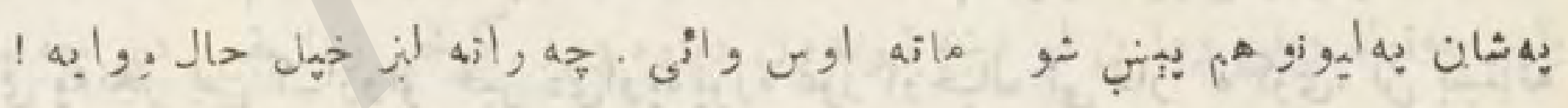

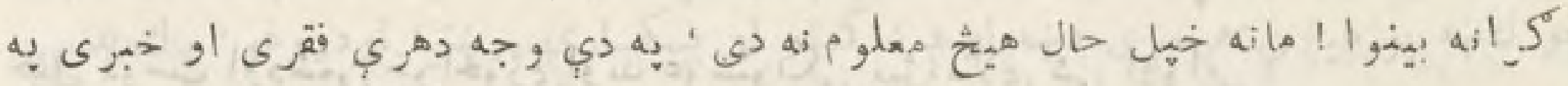

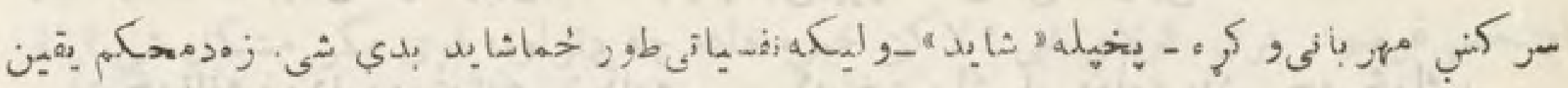

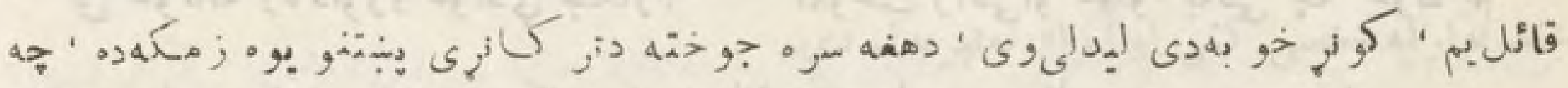

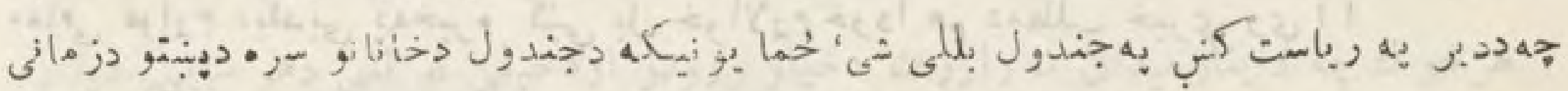

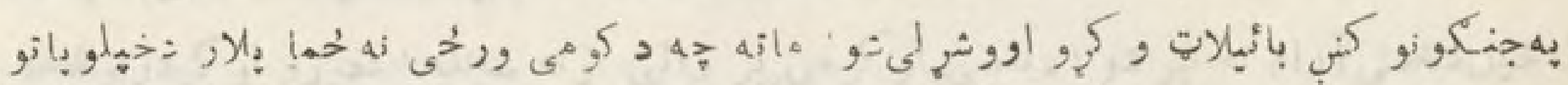

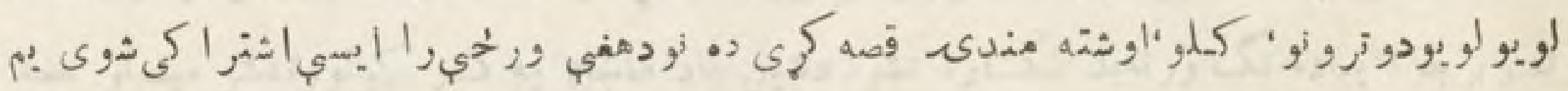

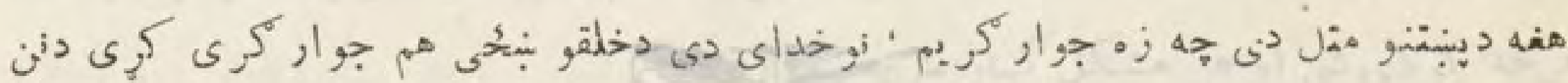

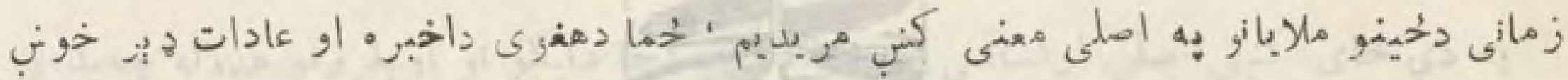

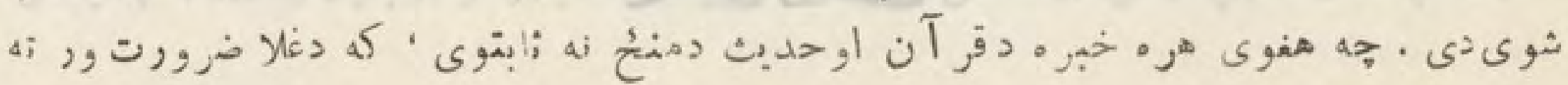




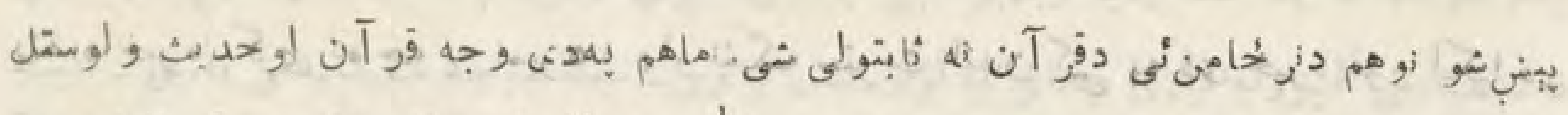

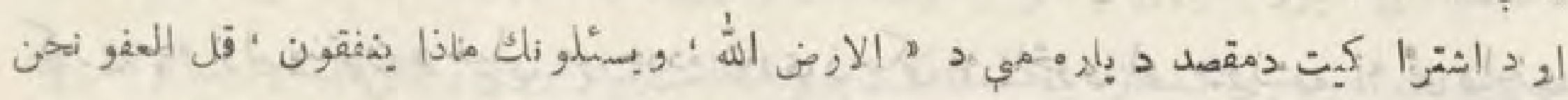

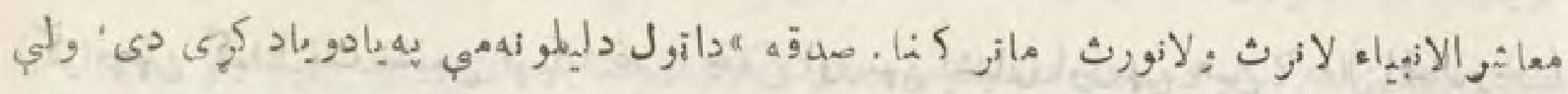

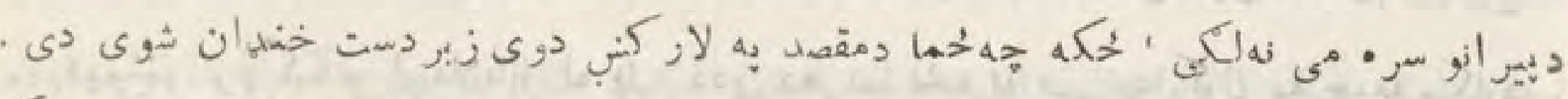

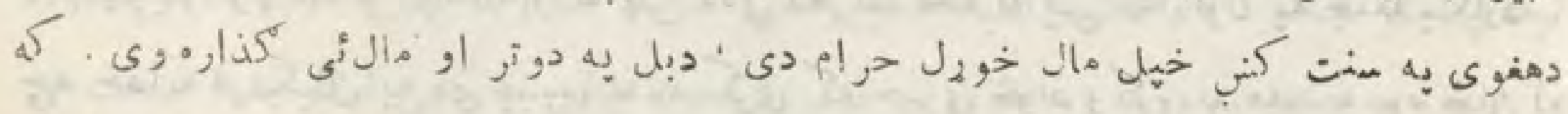

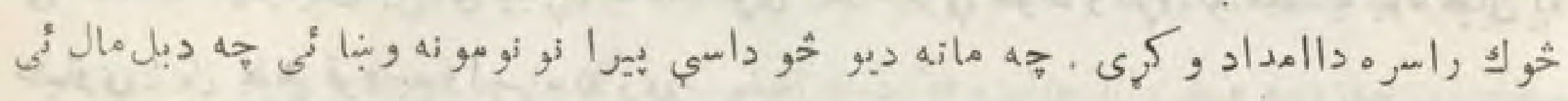

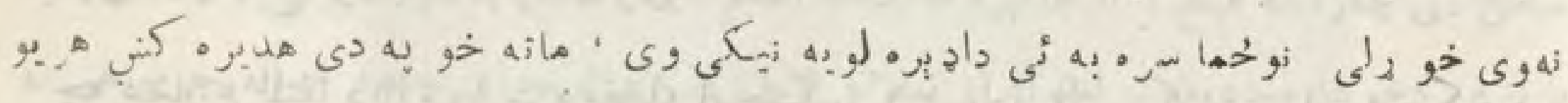
ق قبر

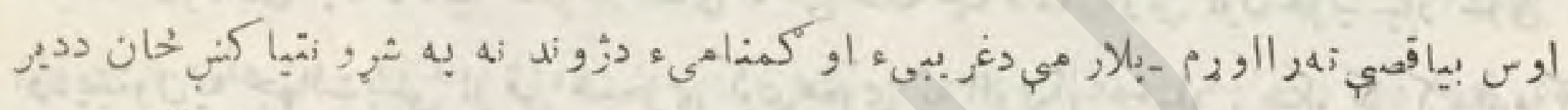

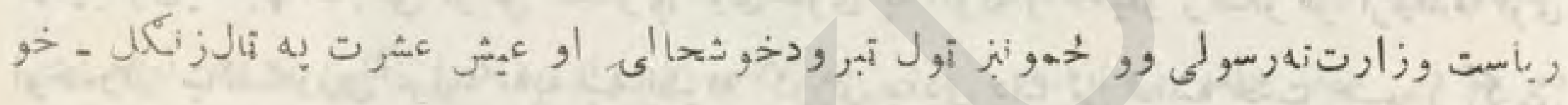

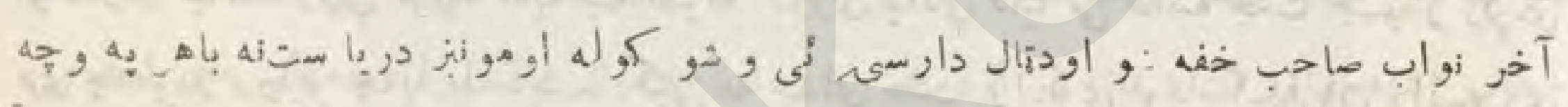

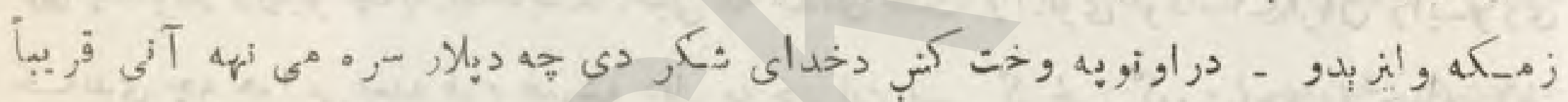

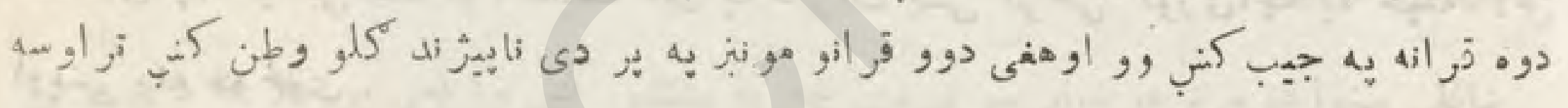
مانلى . موة

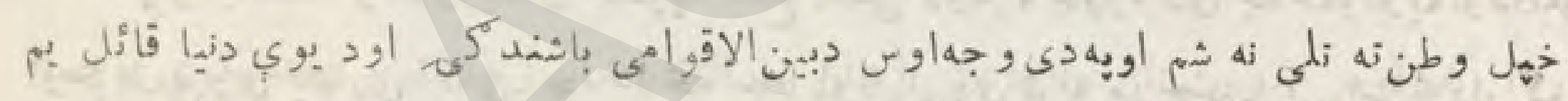

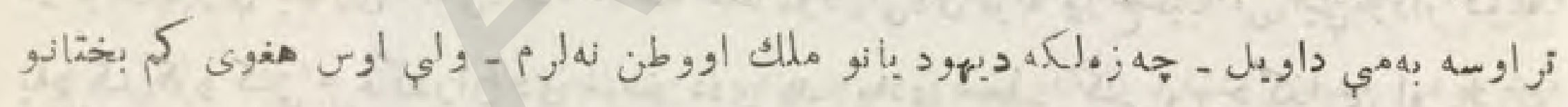

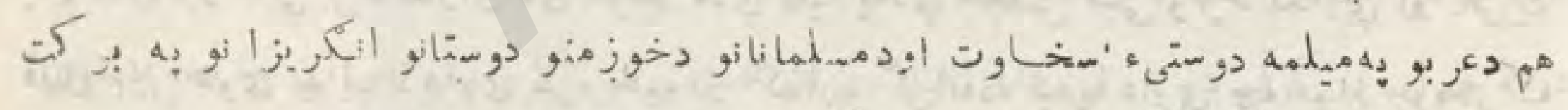

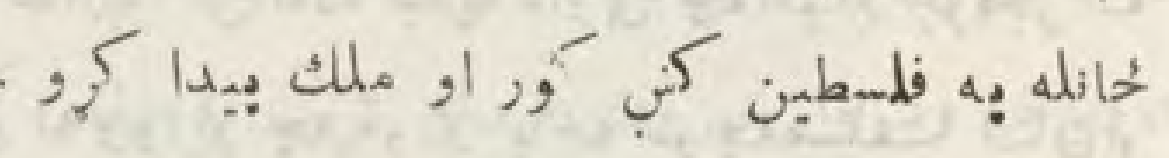

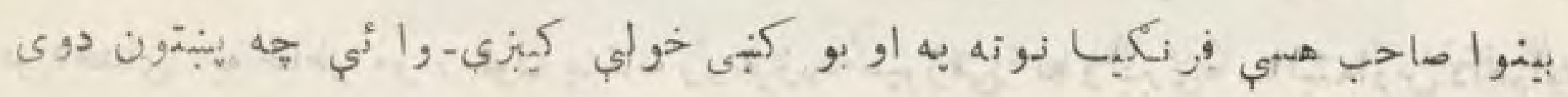

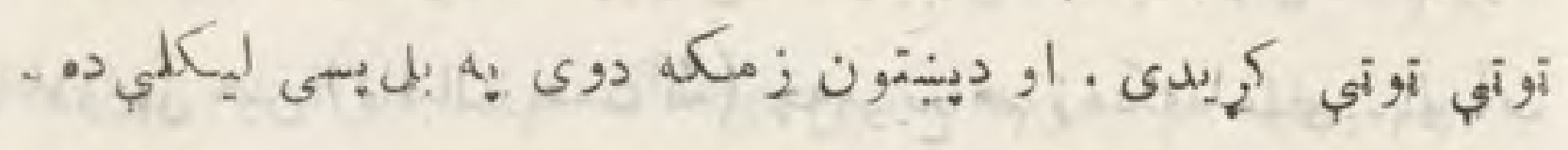

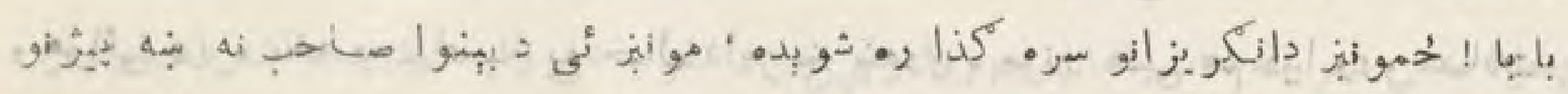

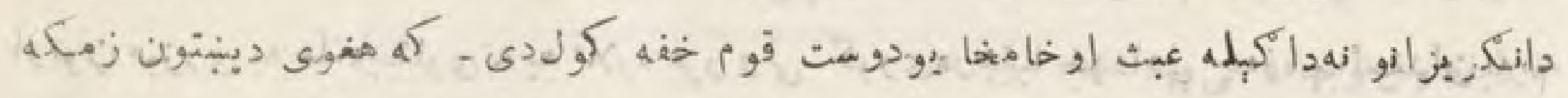

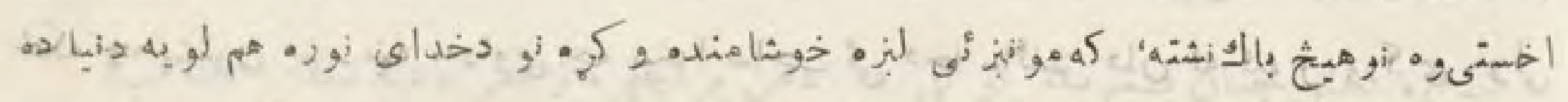

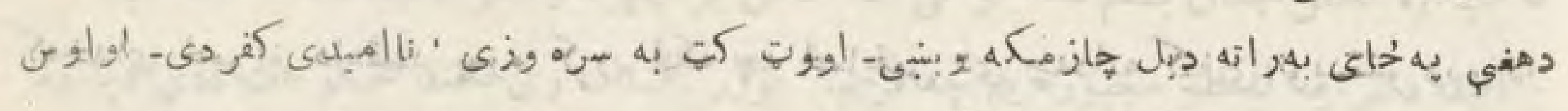

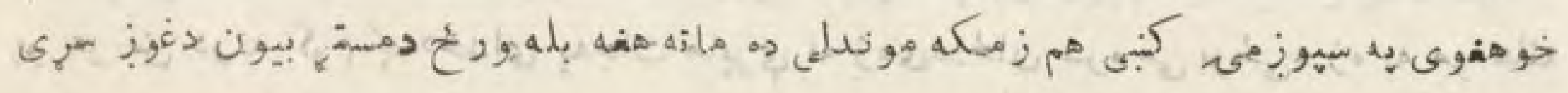


بزّه

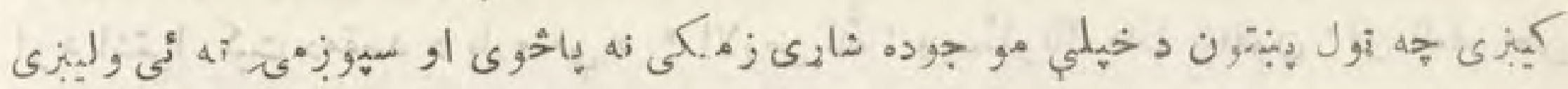

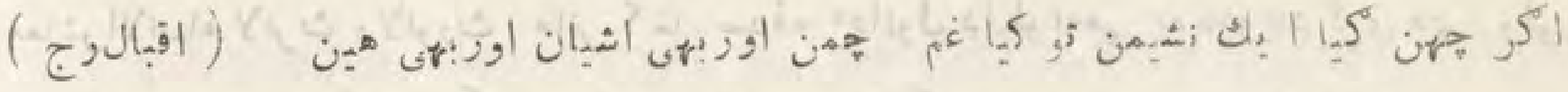

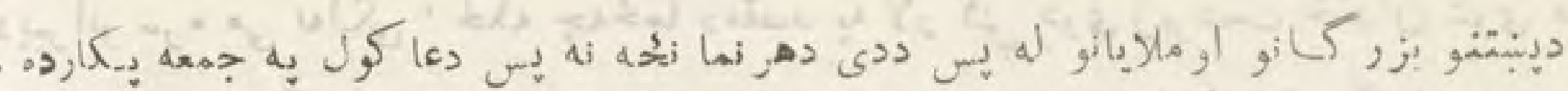

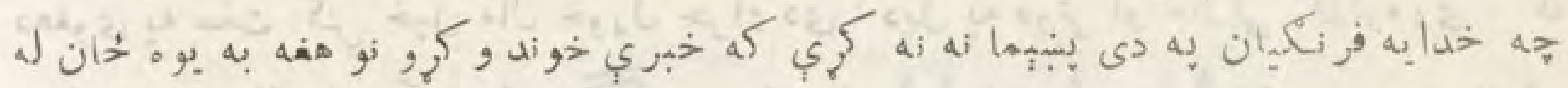

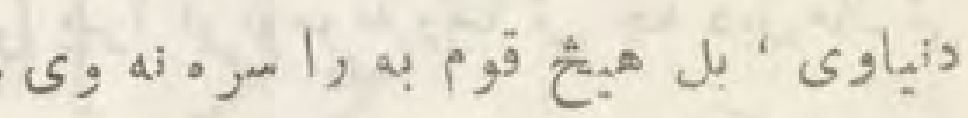

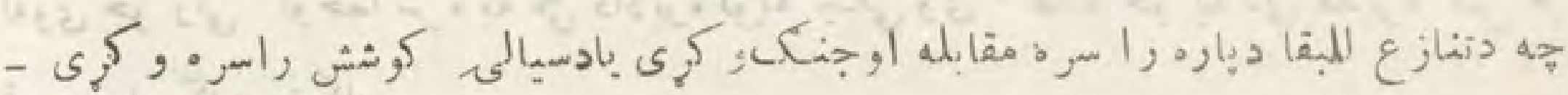

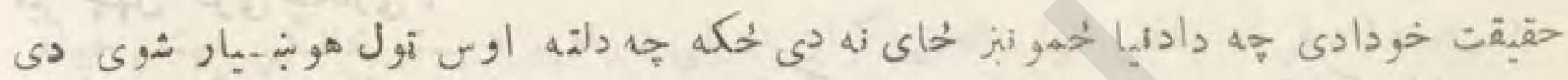

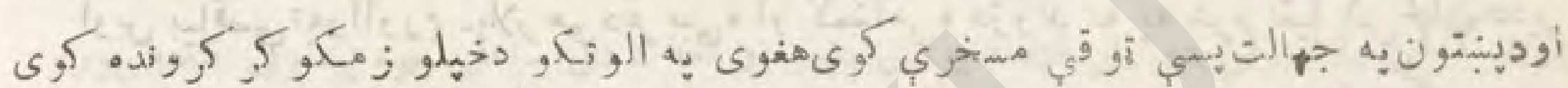

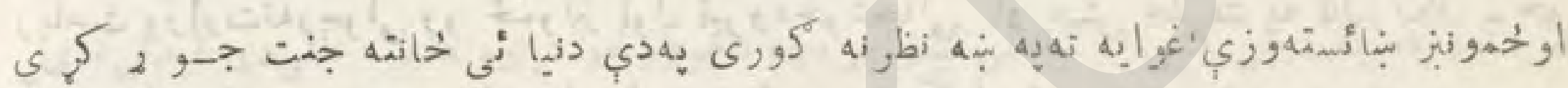

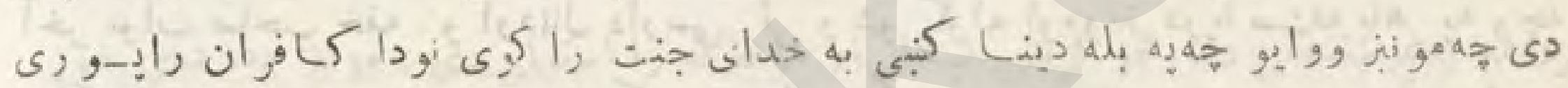
ل لإله اوبن

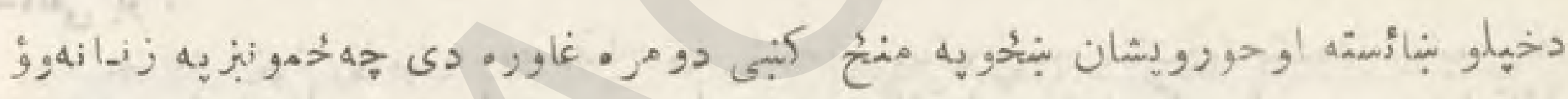

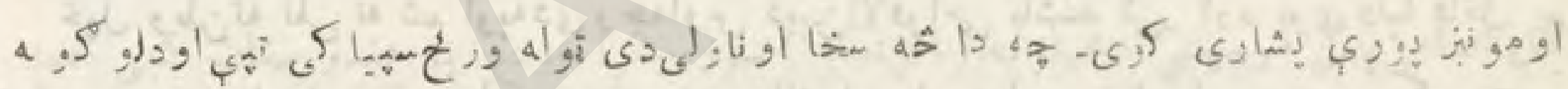

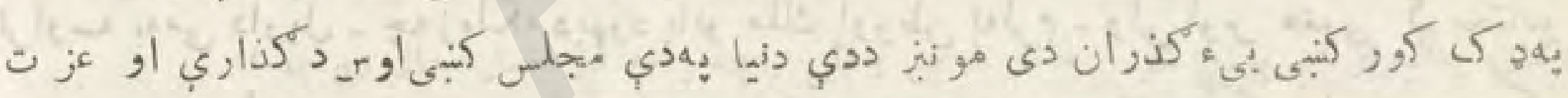

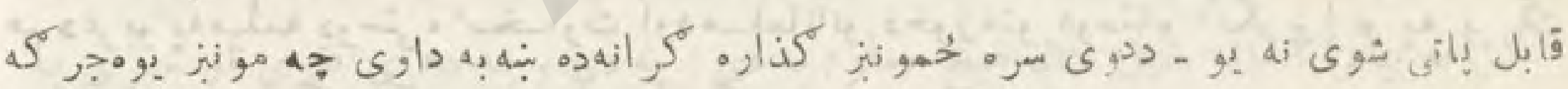

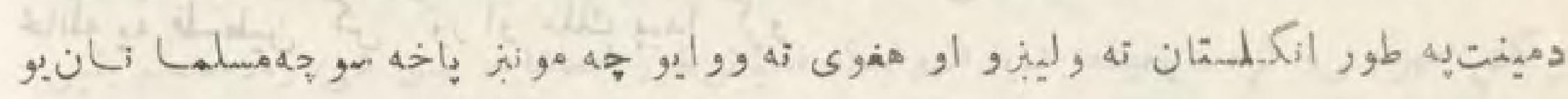

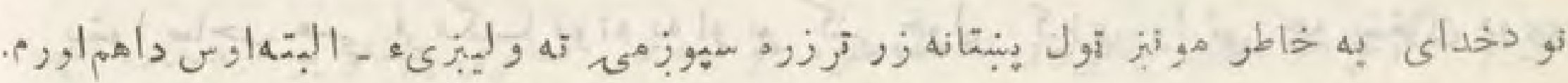

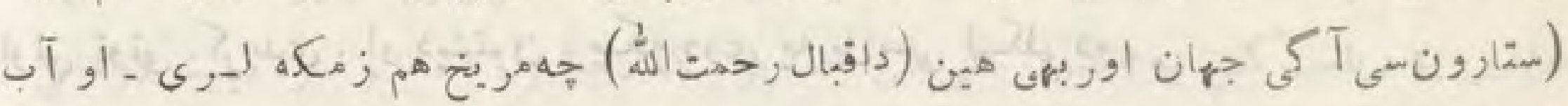

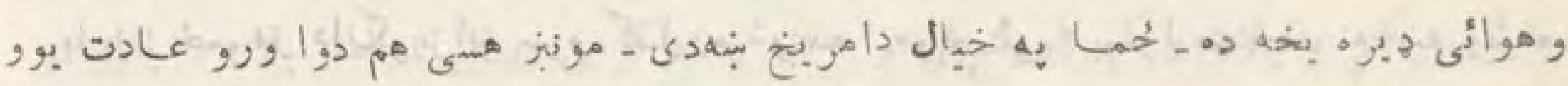

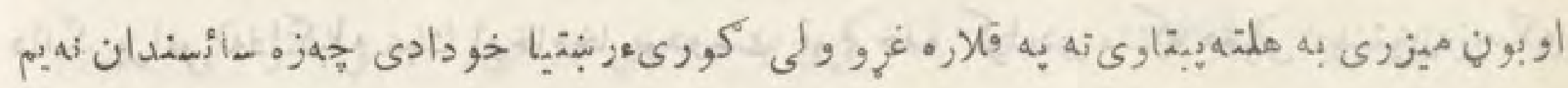

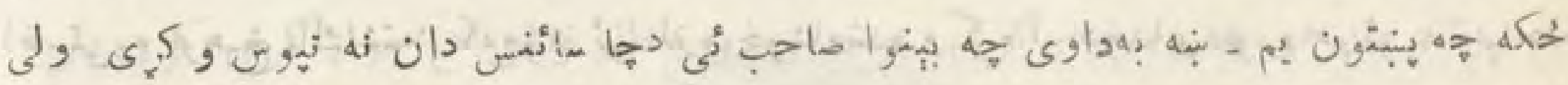
و.

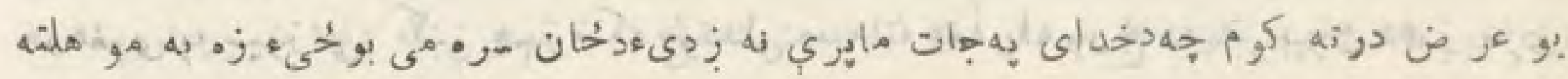




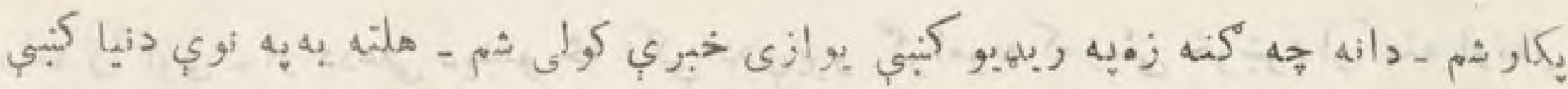

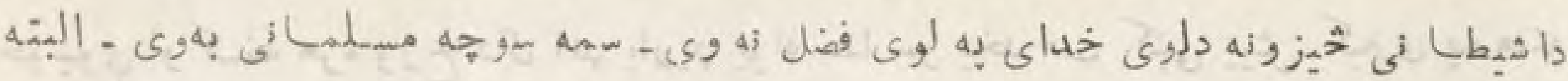

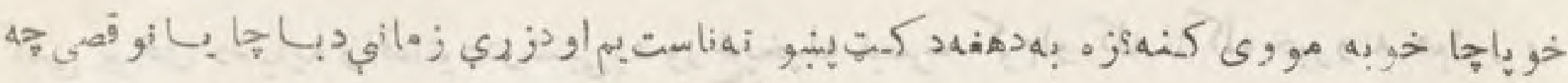

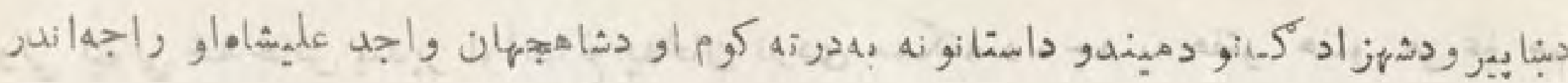

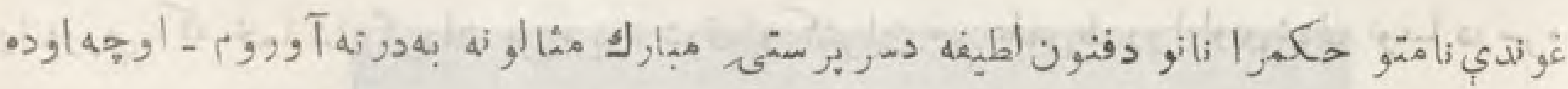

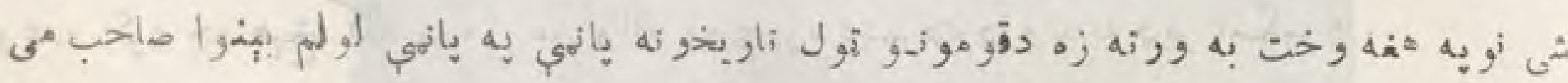

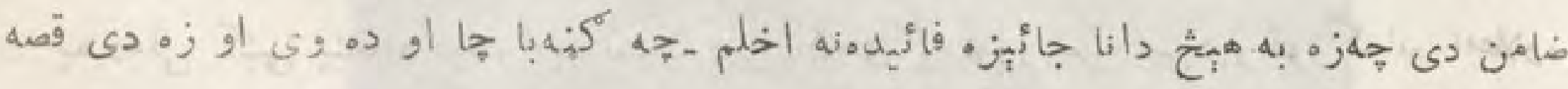

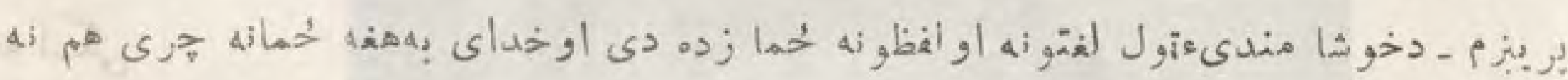

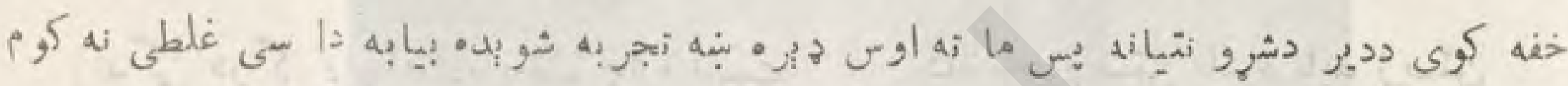

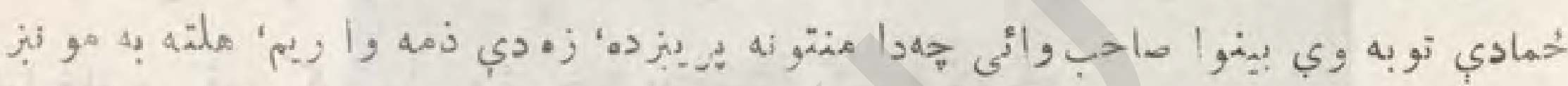

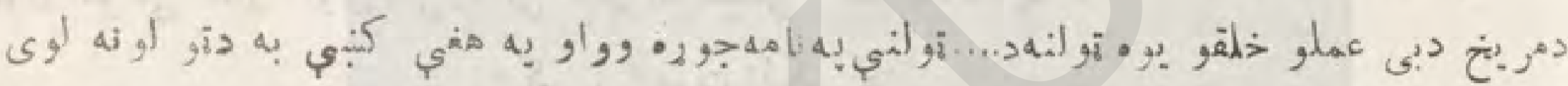

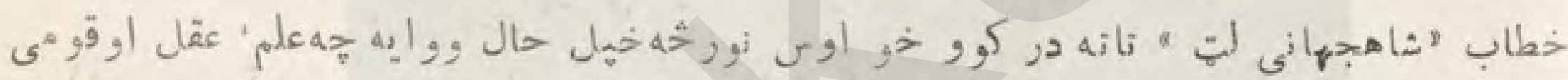

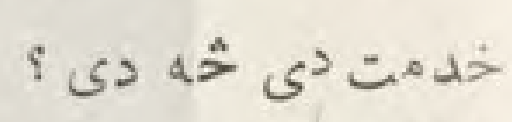

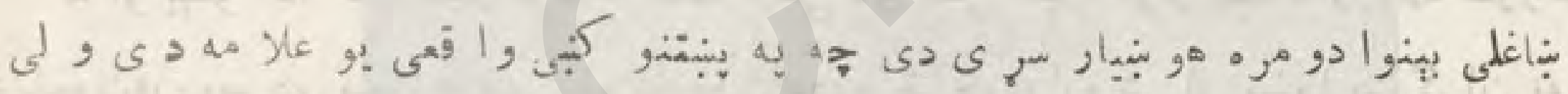

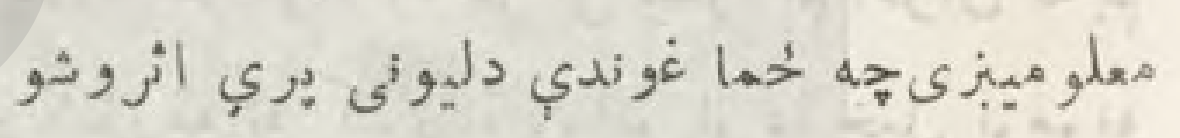

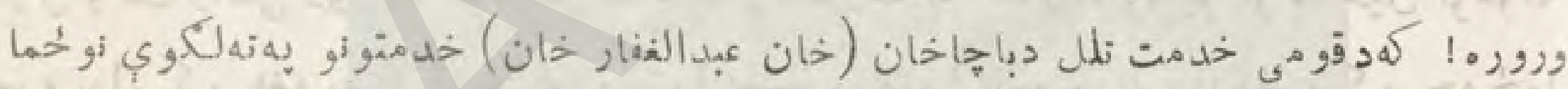

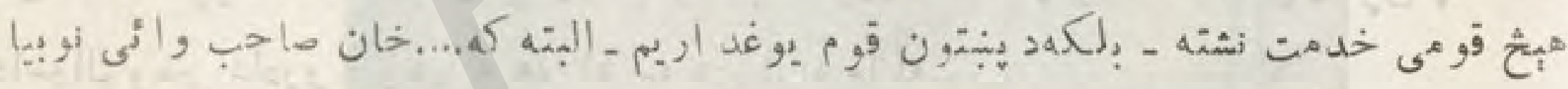

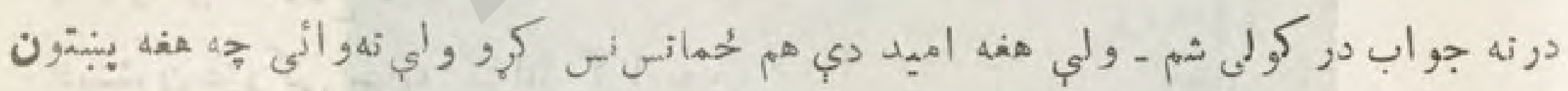

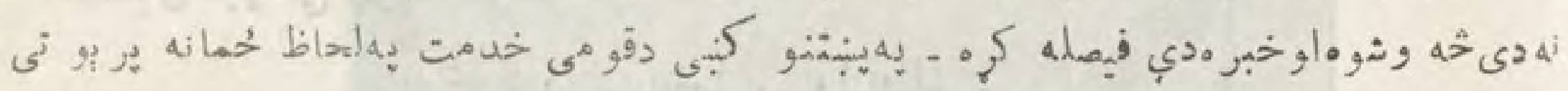

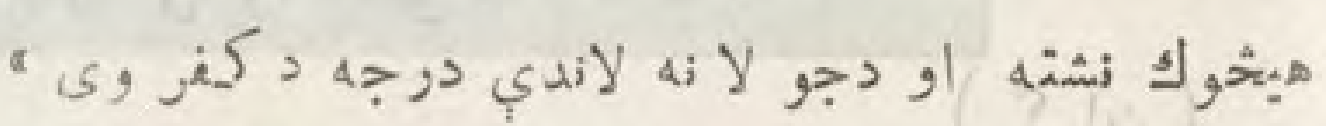

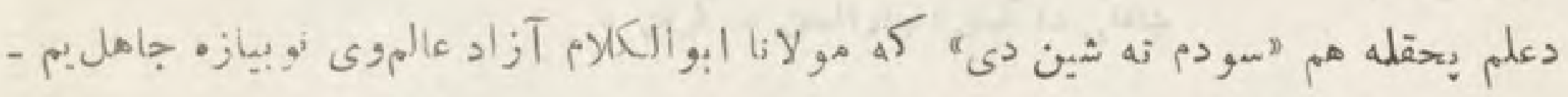

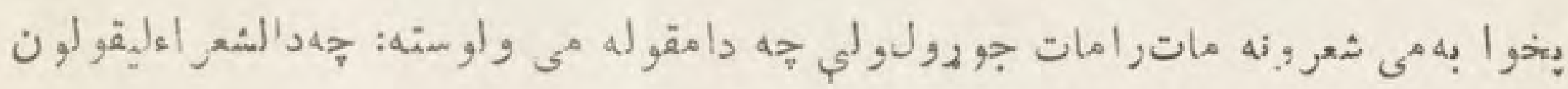

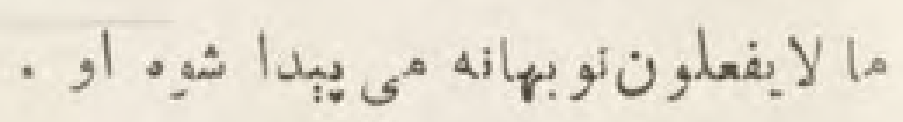

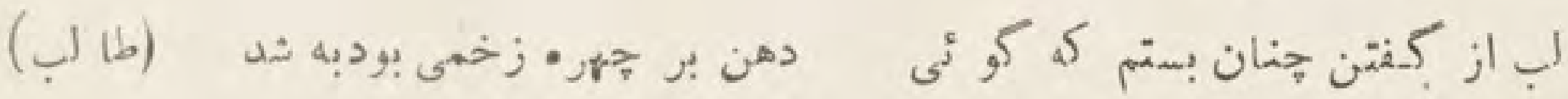

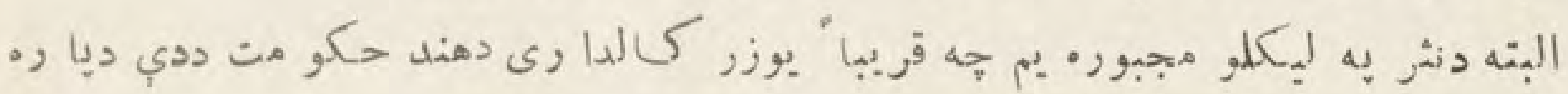




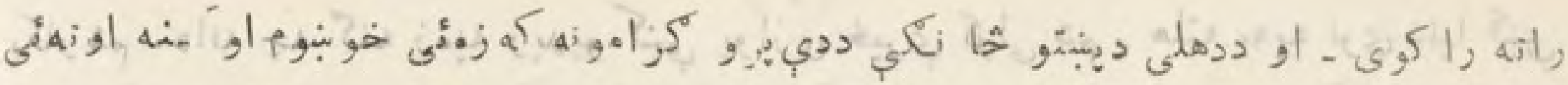

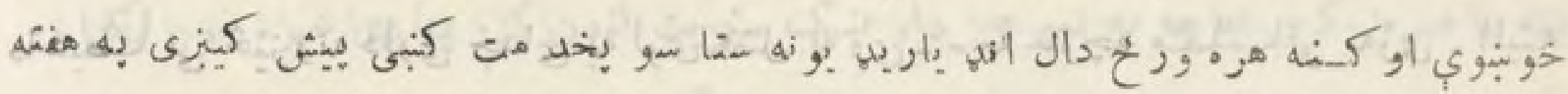

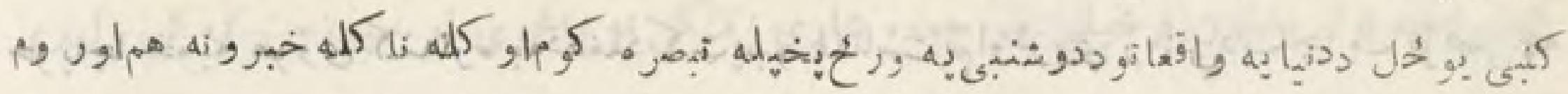

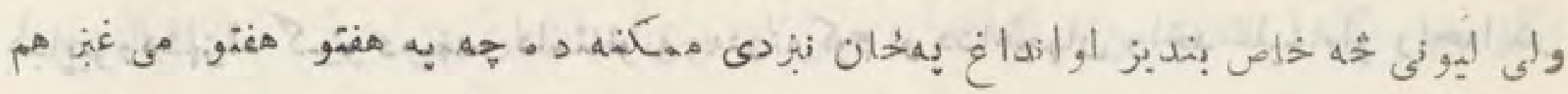

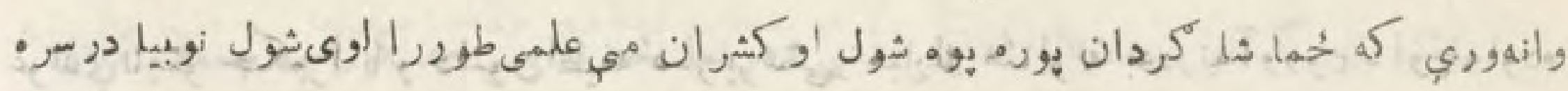

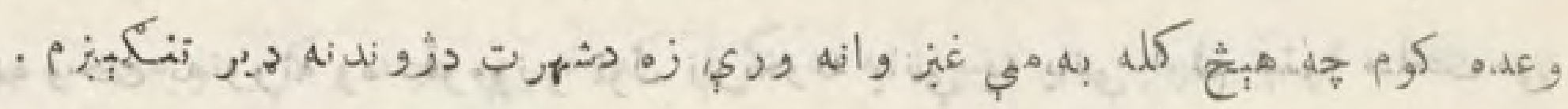

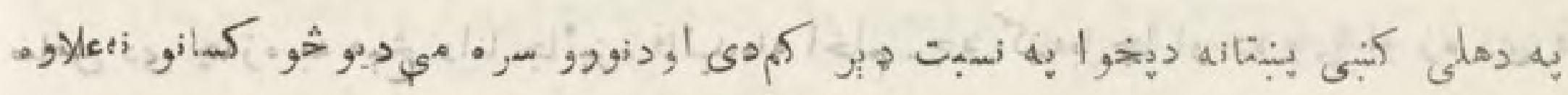
'Sil dis

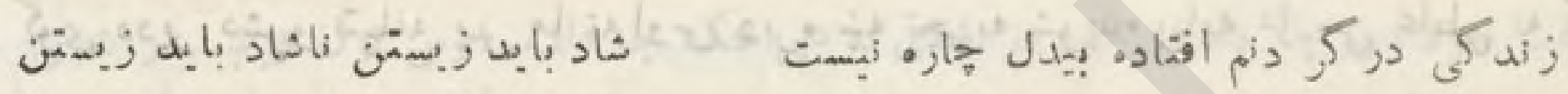

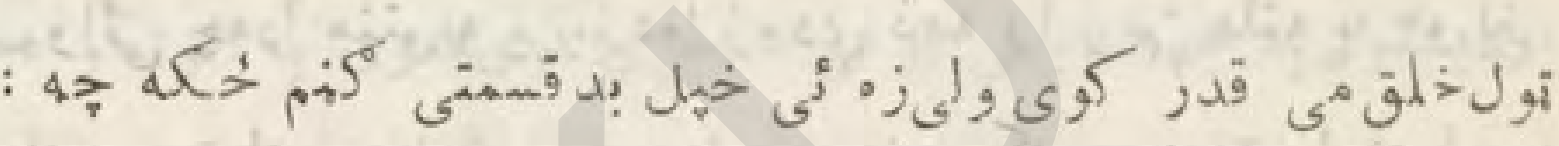

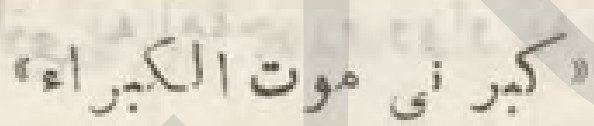

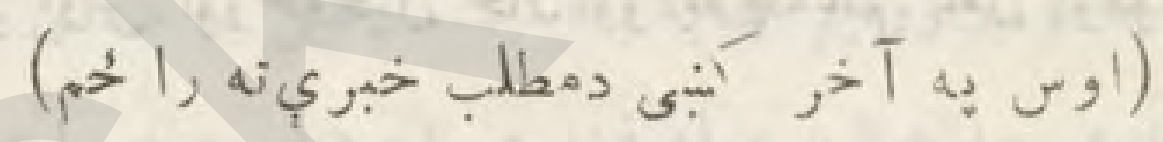

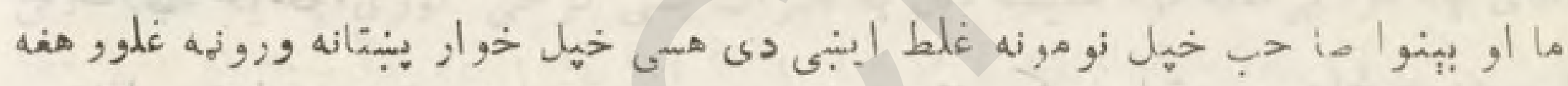

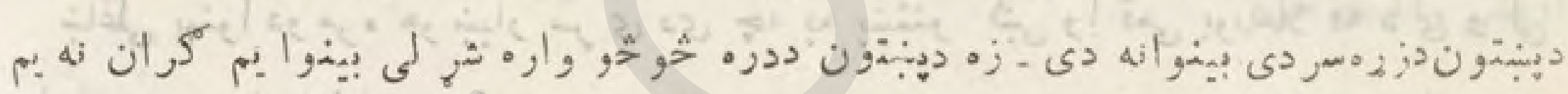

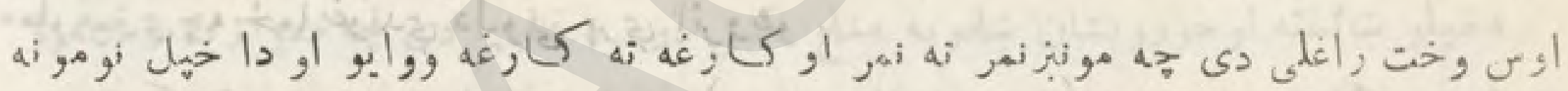

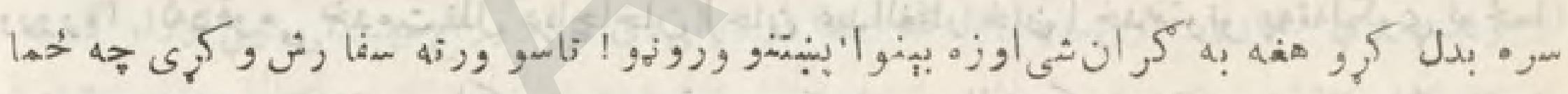

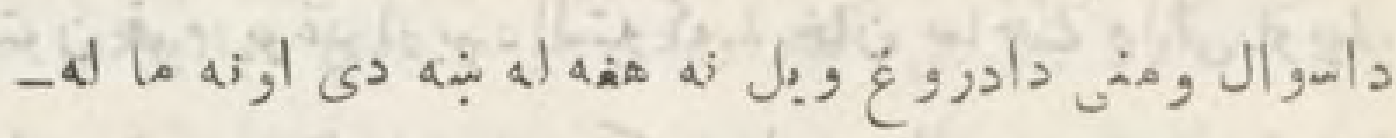

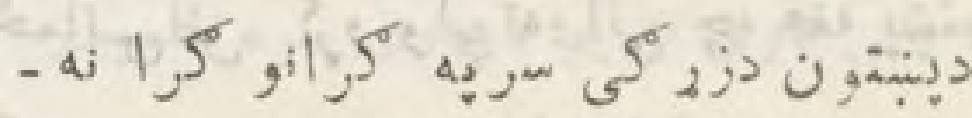

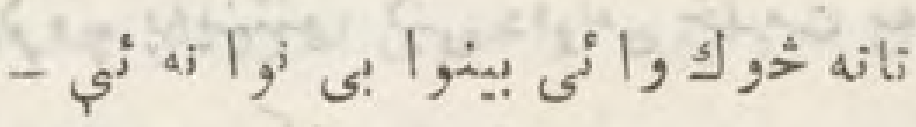

$(0,5)$ 


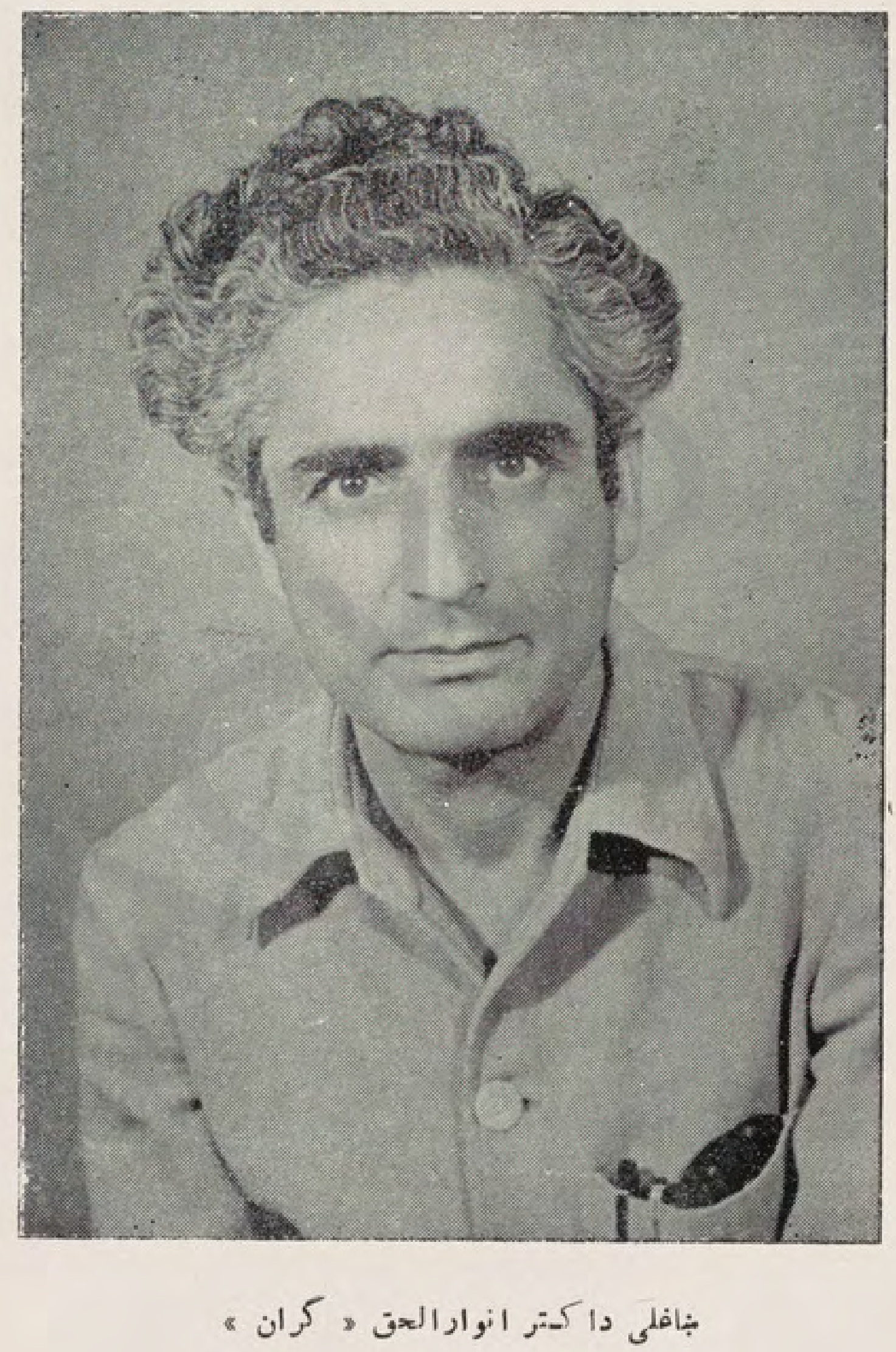



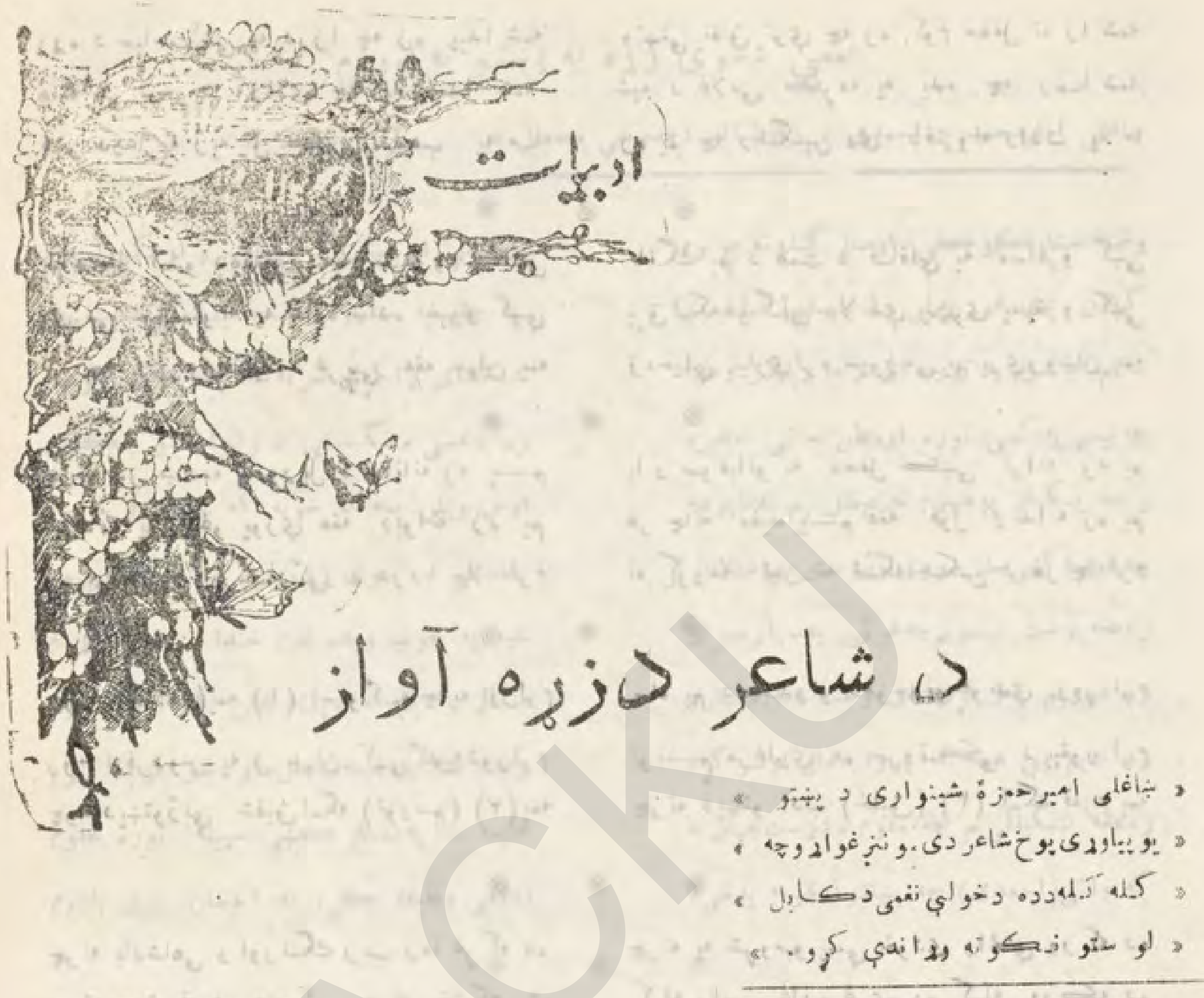

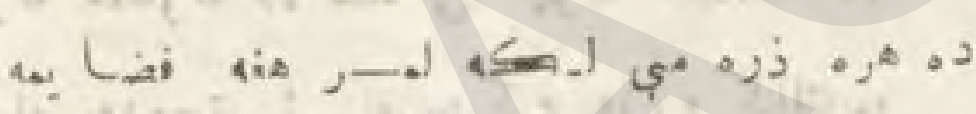

4إla

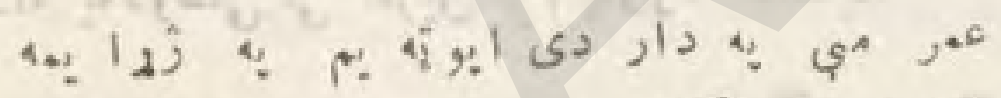

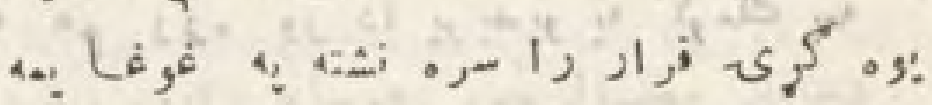

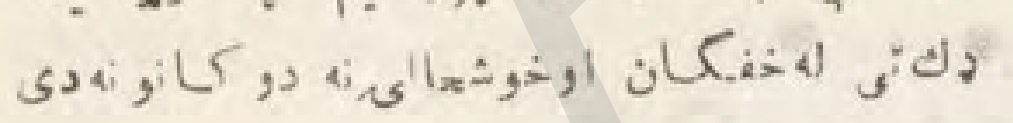

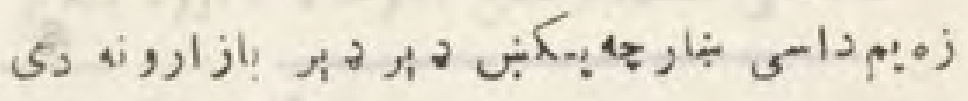

$$
\text { (4) (2) }
$$

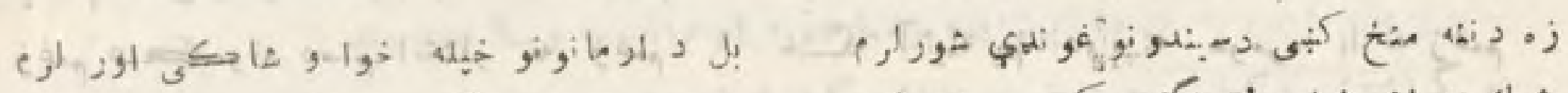

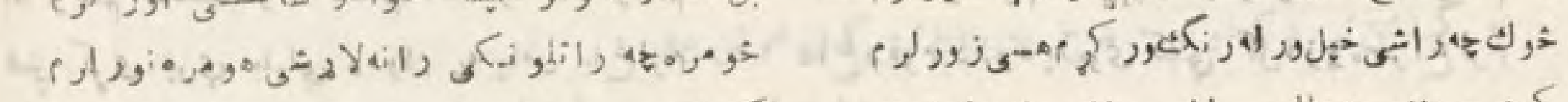

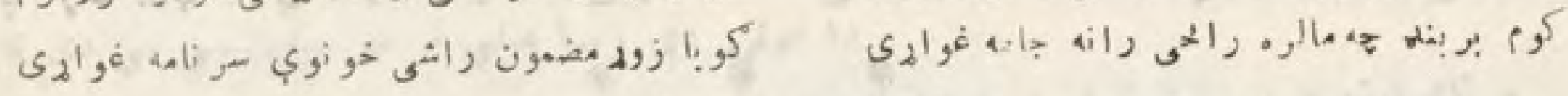

(9) 9

لى "0

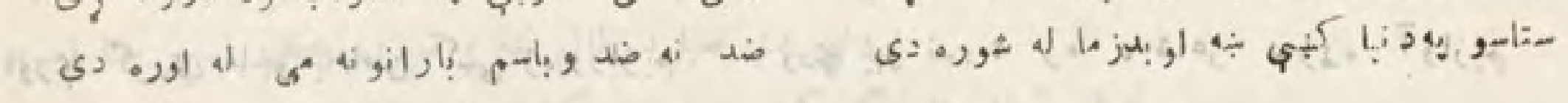

$$
\text { (2) } 8
$$

4.

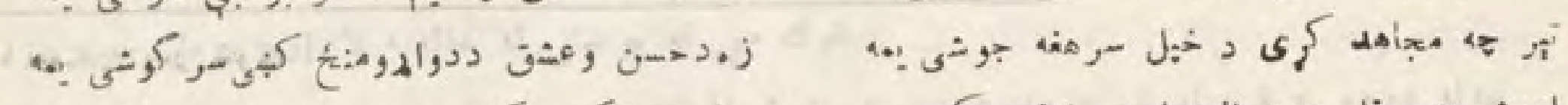

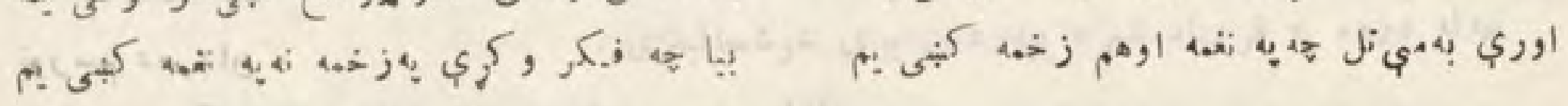




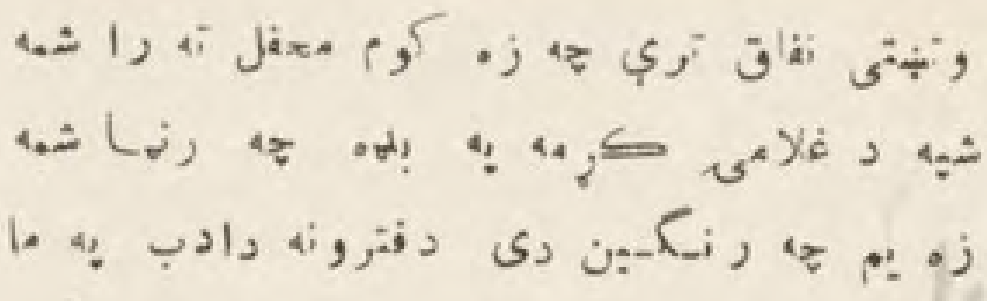

8

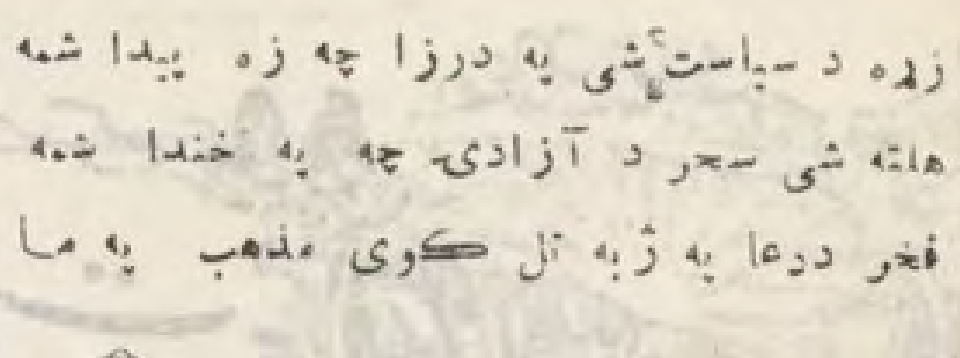

(9)

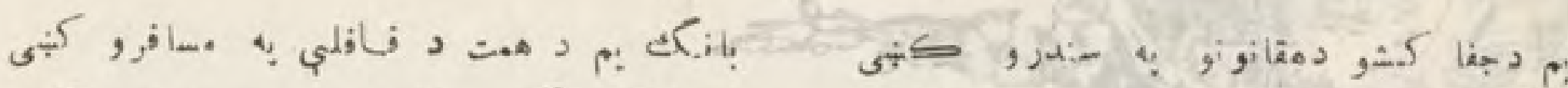

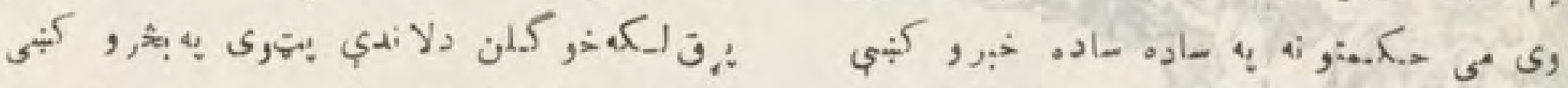

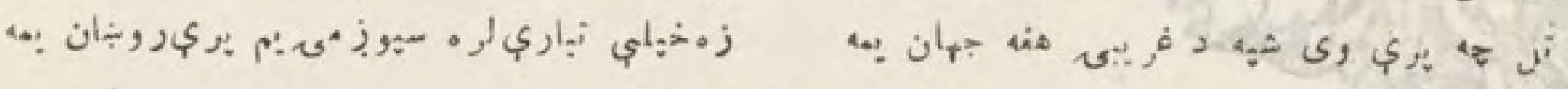
(2) (6)

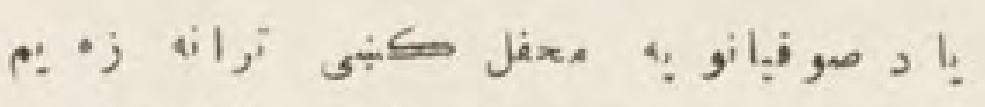

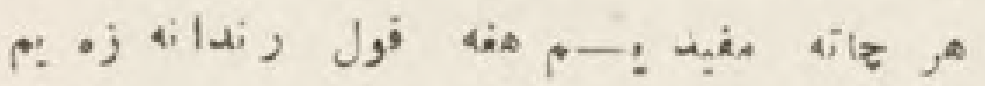

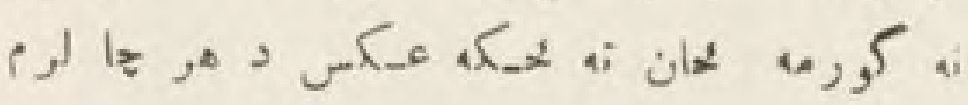

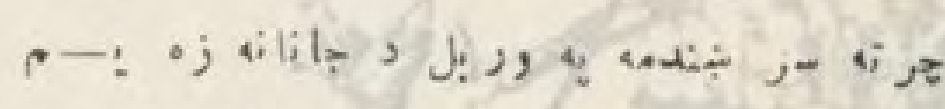

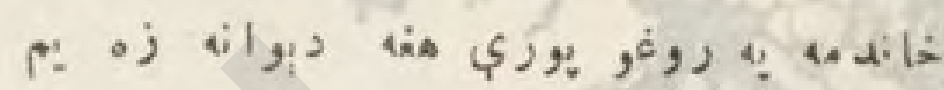

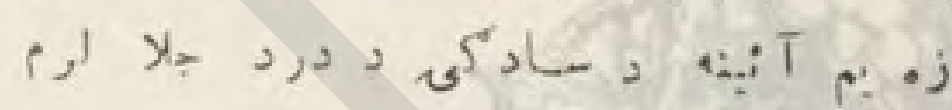
(2) 9

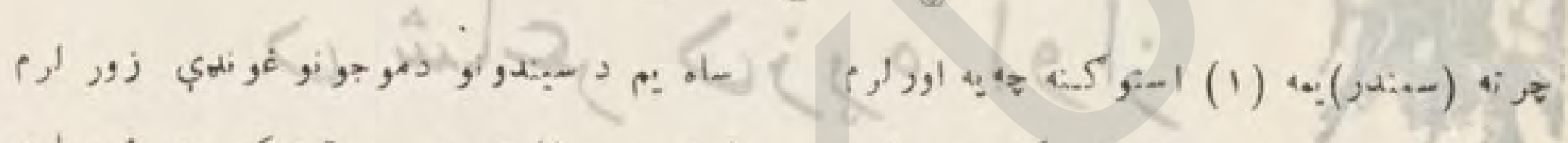

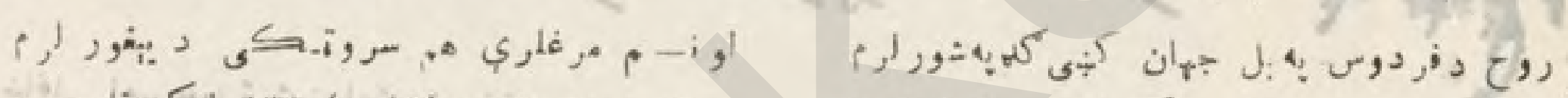

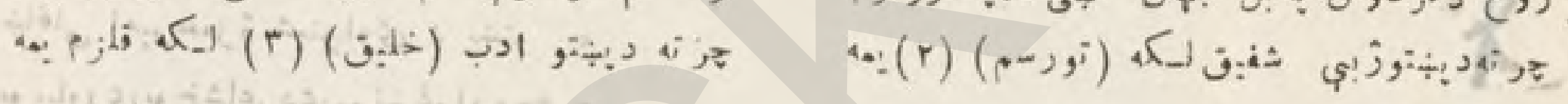
(2) (2)

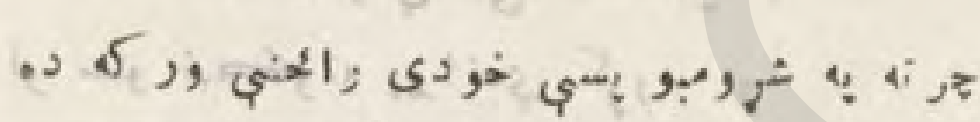
0 د ك

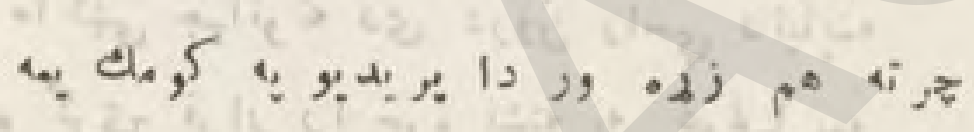

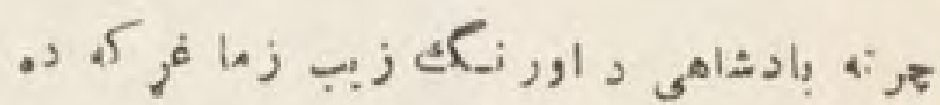

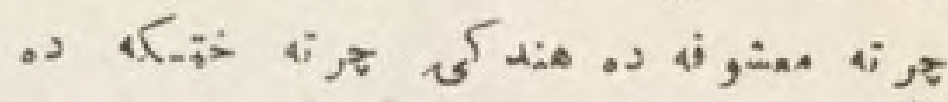

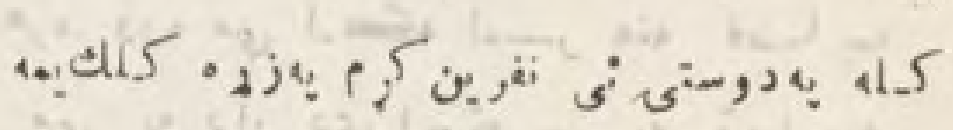

\section{(9)}

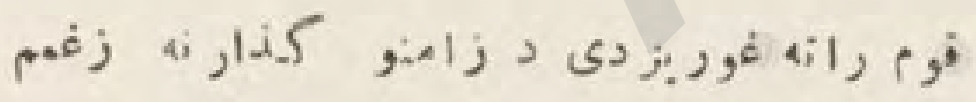
(9)

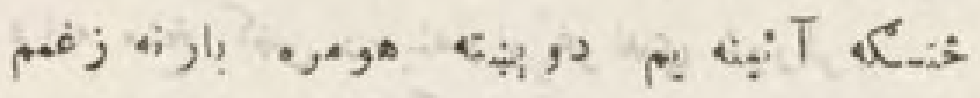

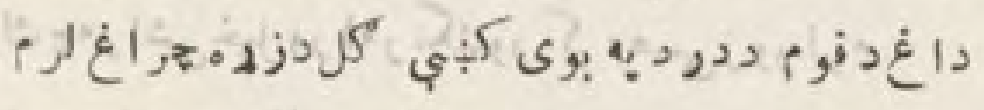

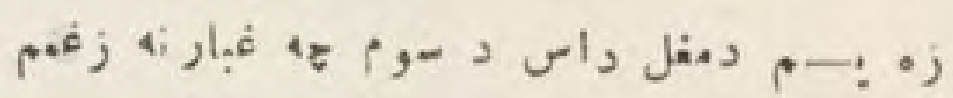

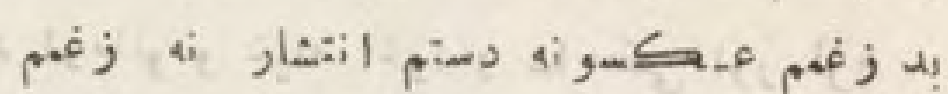

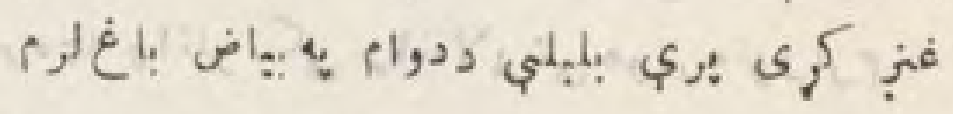

(2) 6)

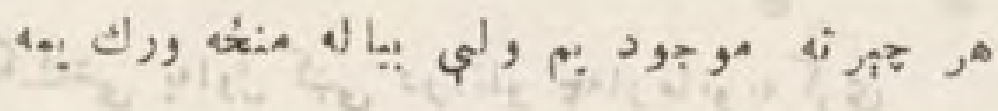

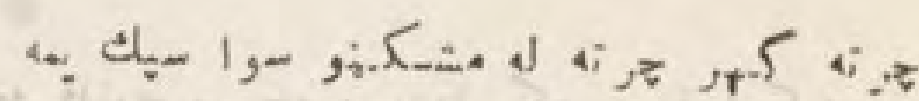

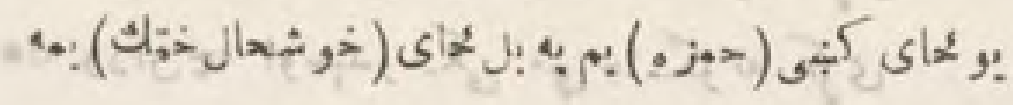

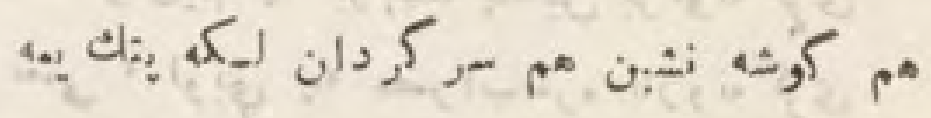

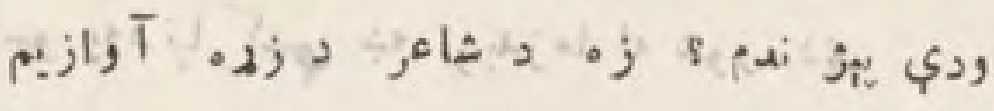 اوري كوري هاخو بهباطن كينى زبه:وراز.بم 


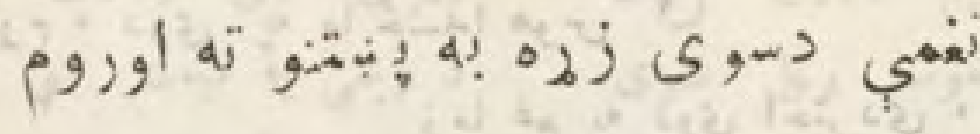

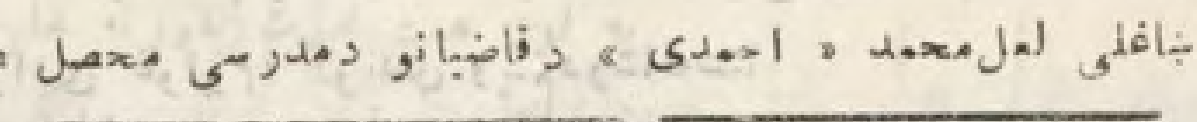

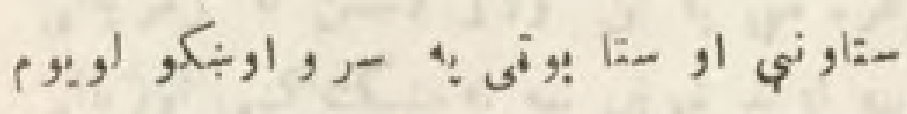

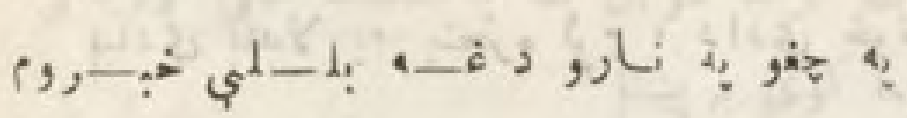

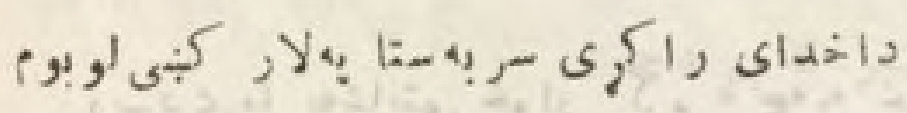

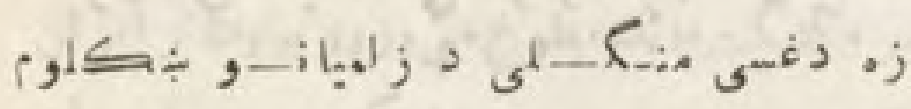

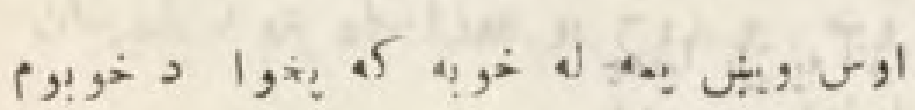

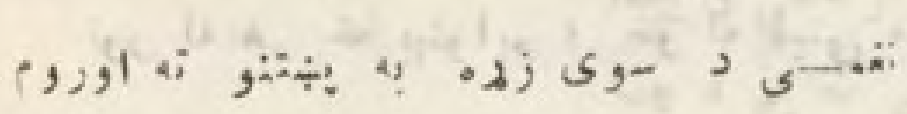

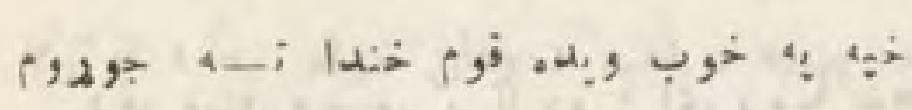

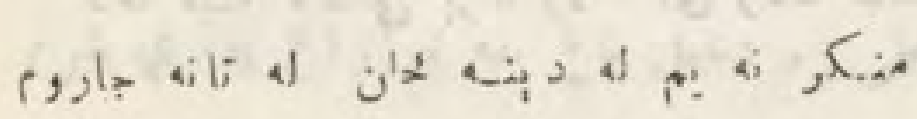

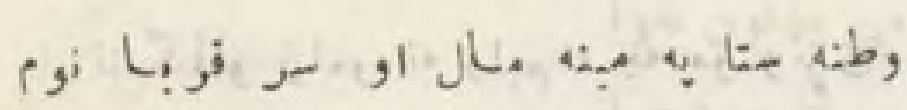

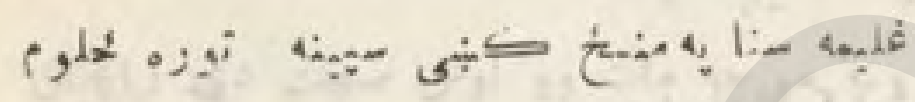

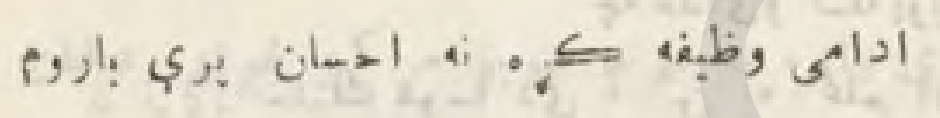

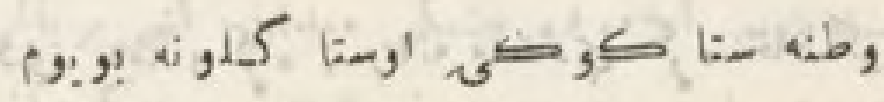

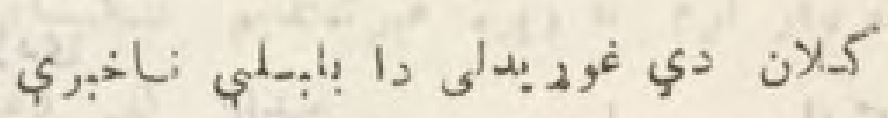

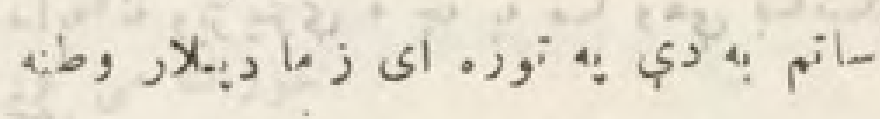

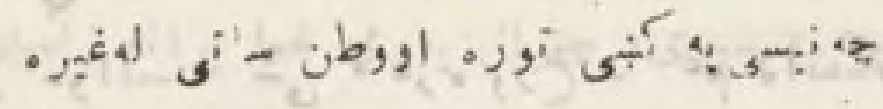

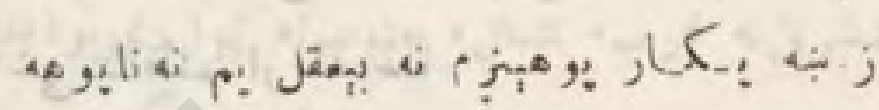

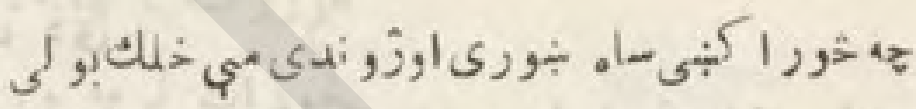
管

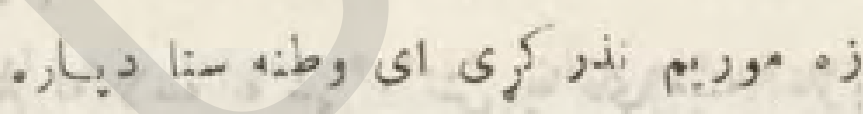

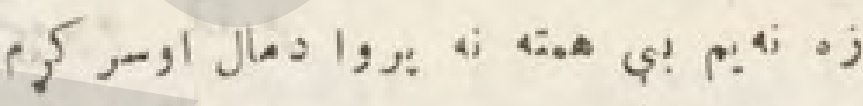

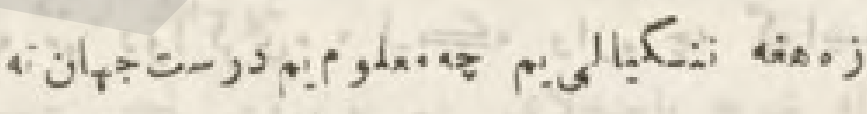
ك

(2)

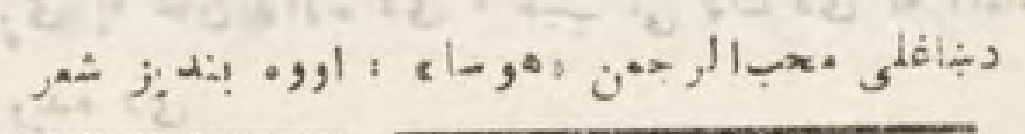

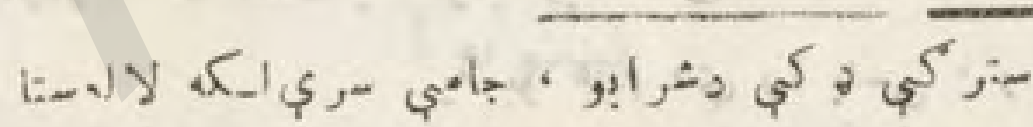

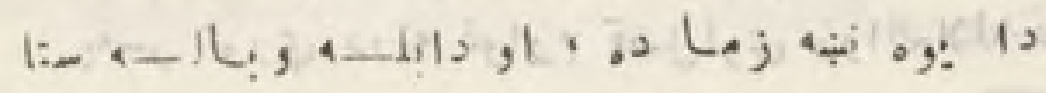

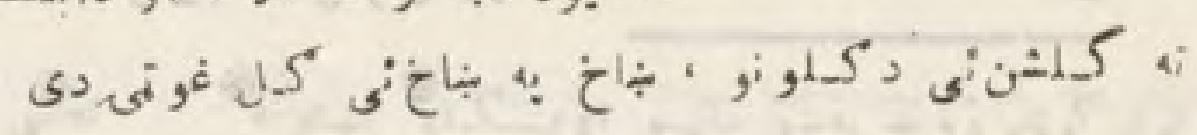

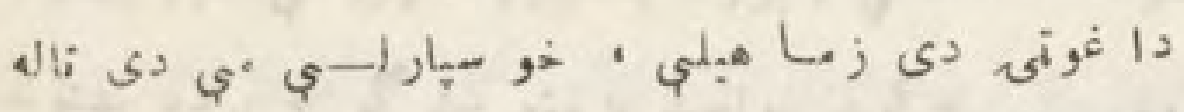

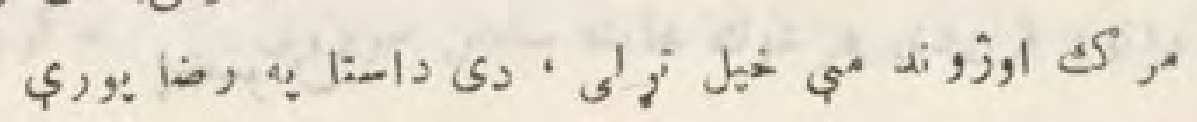

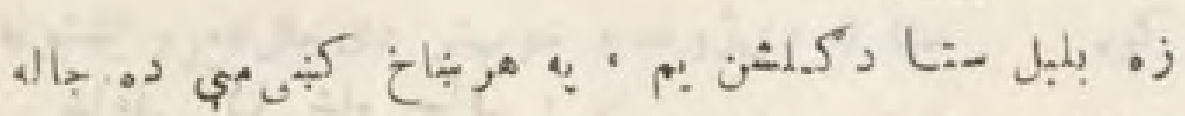

$$
\text { - }
$$

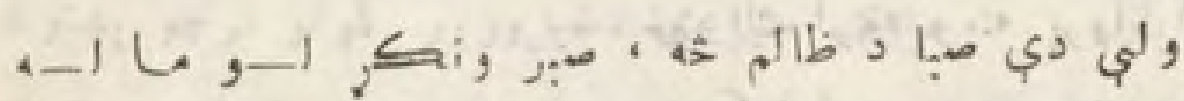

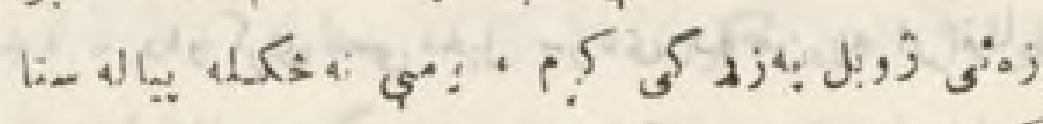

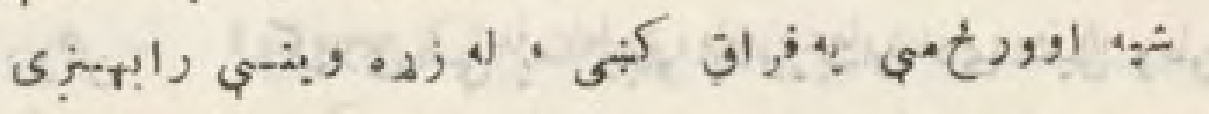

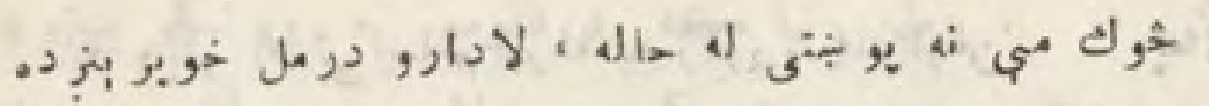

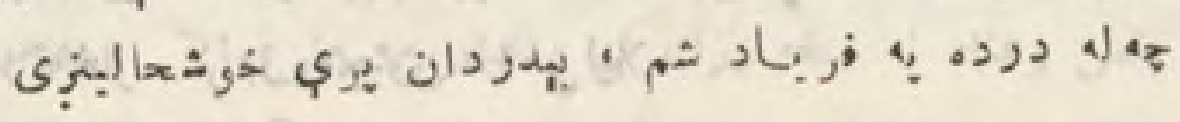

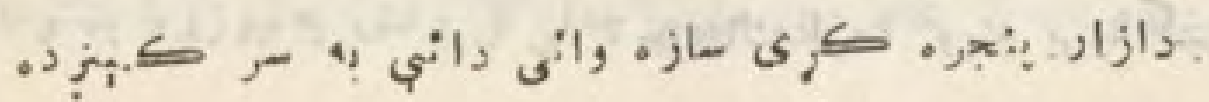




\section{(ir)}

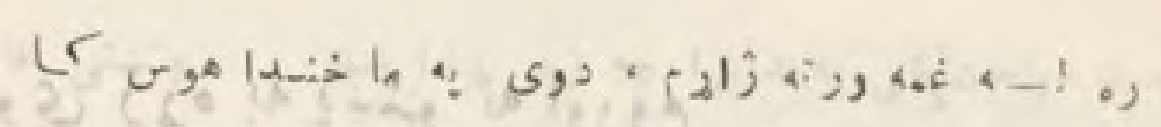

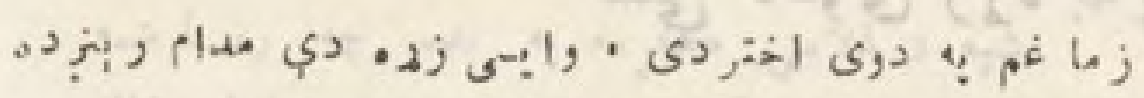

Mal, Latroty

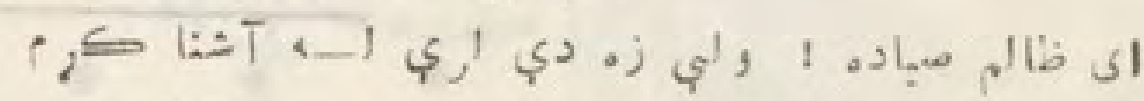

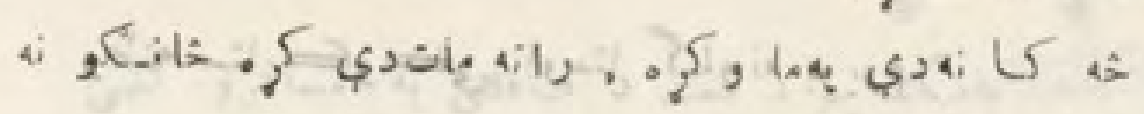

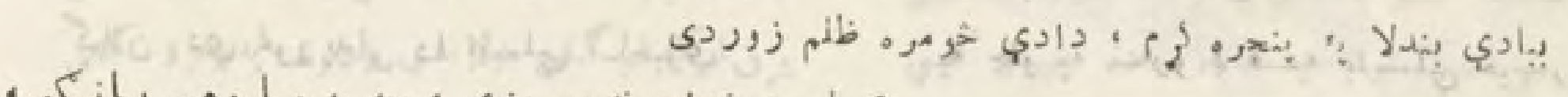

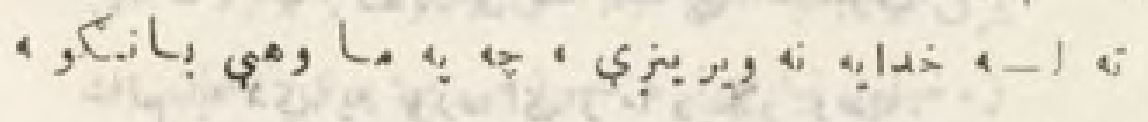

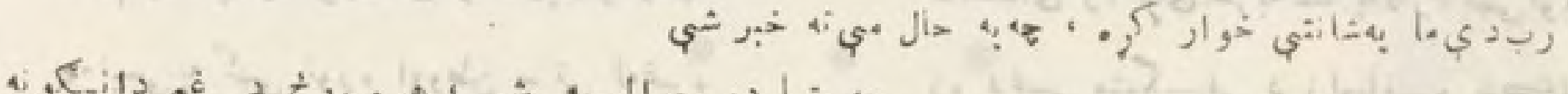

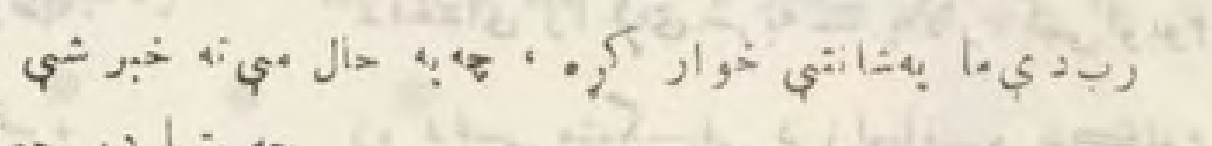

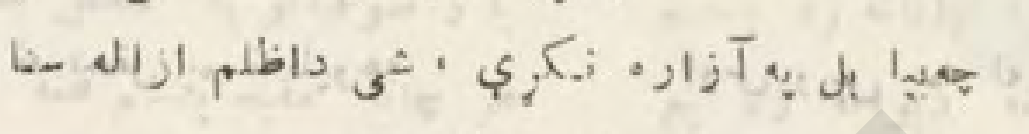

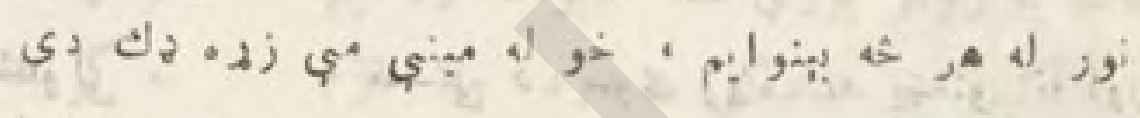

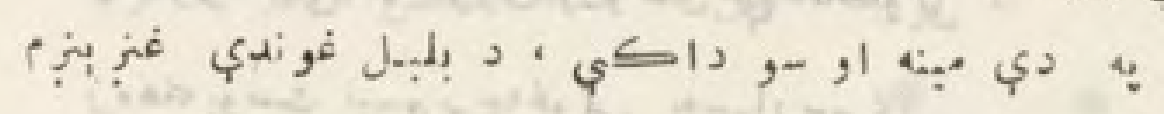

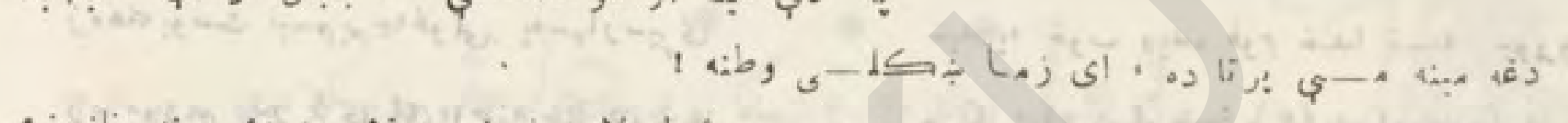

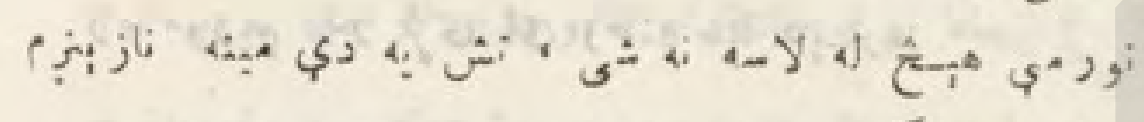

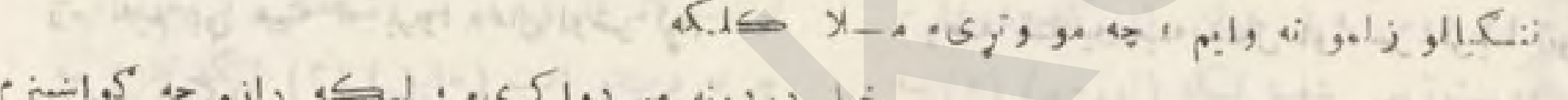

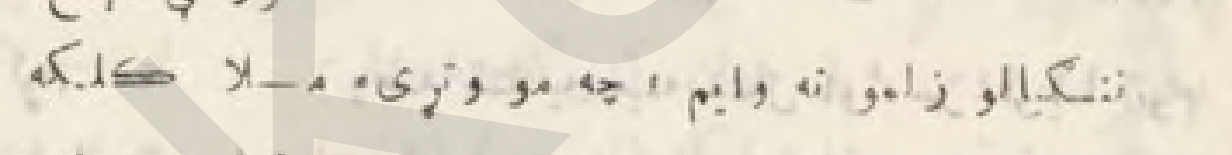

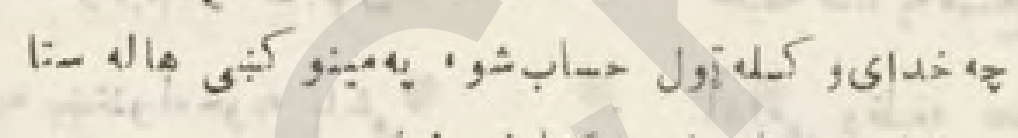

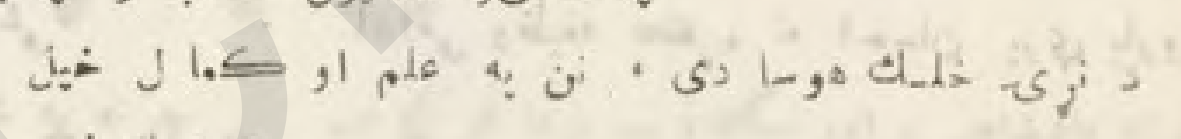

4.

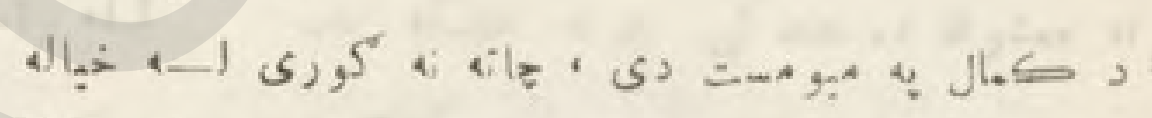

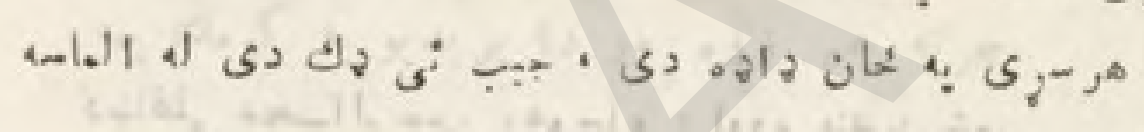

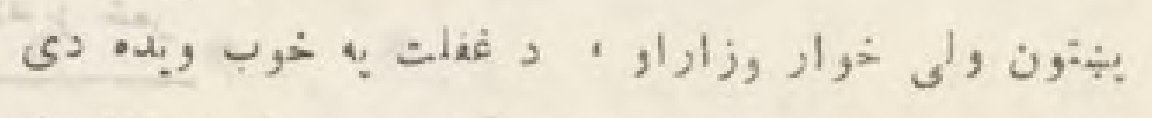

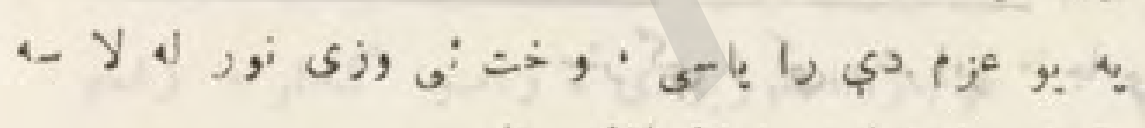

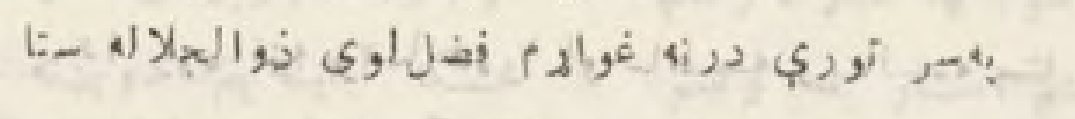$$
\text { g) } 2 \text { की } 2010
$$

$$
\begin{aligned}
& \text { i) grime }
\end{aligned}
$$

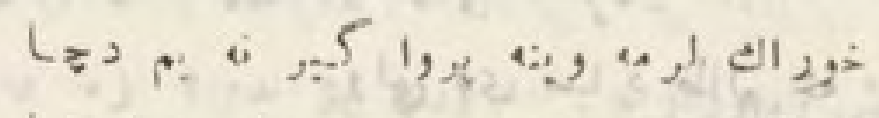

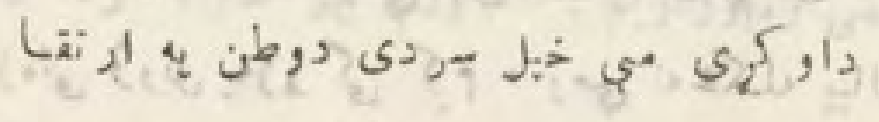

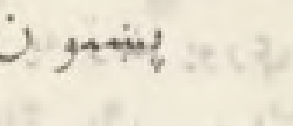

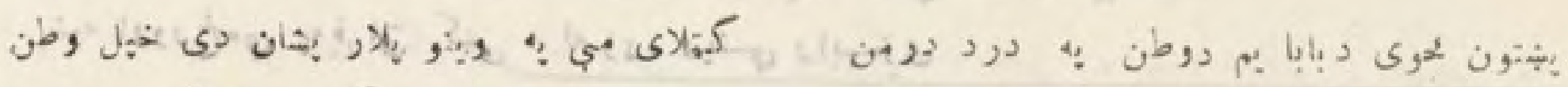

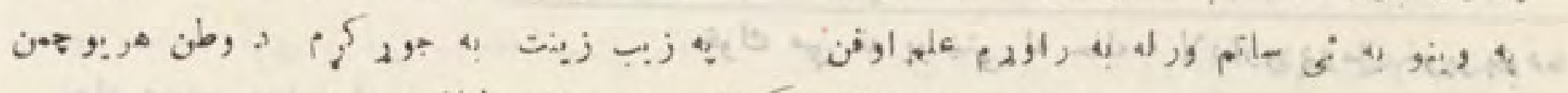

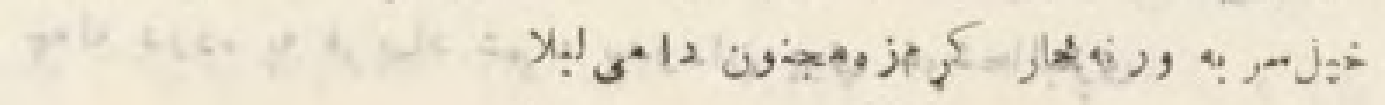

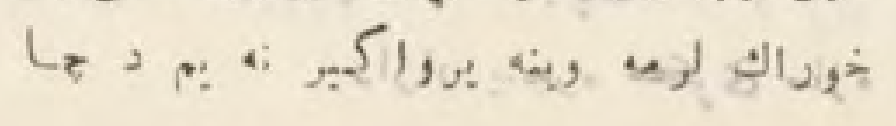




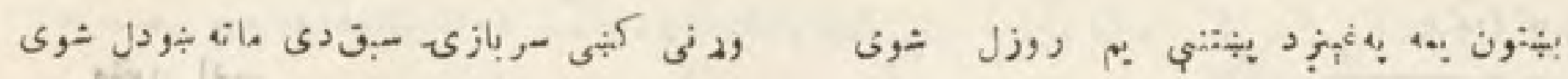

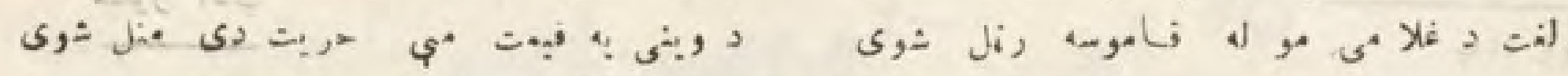

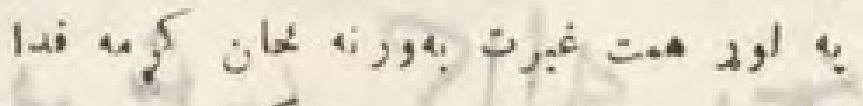

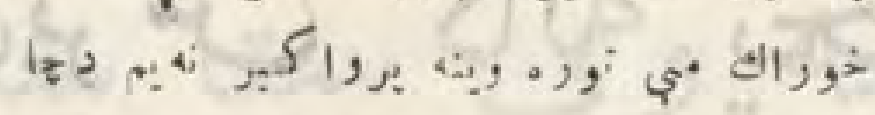

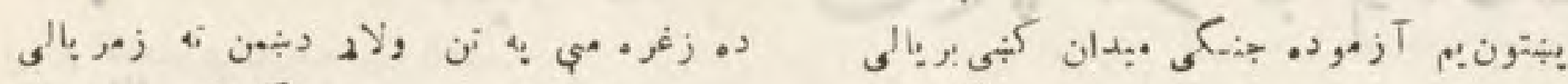

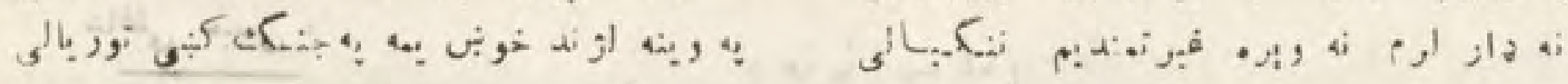

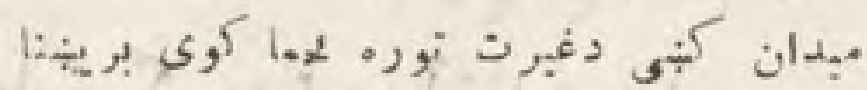

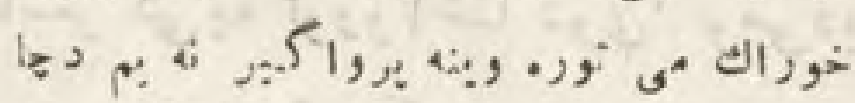

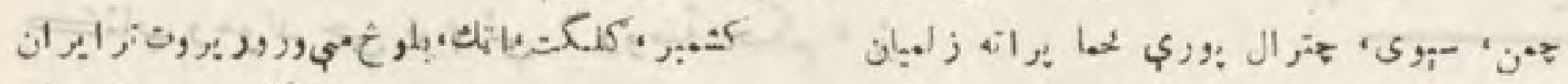

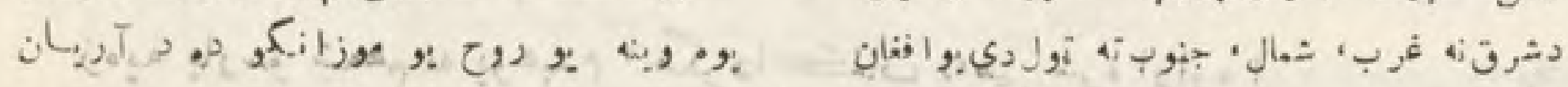

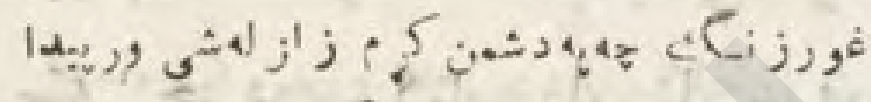

$$
\begin{aligned}
& \text { Lج د : }
\end{aligned}
$$

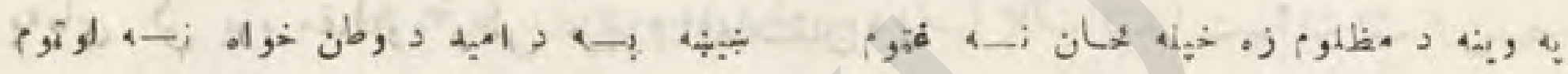

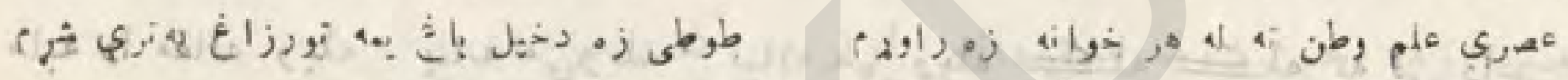

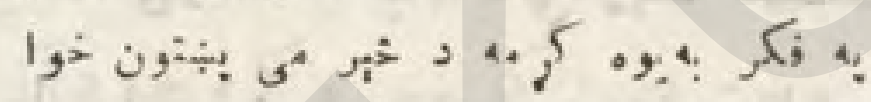

$$
\begin{aligned}
& \text { Le }
\end{aligned}
$$

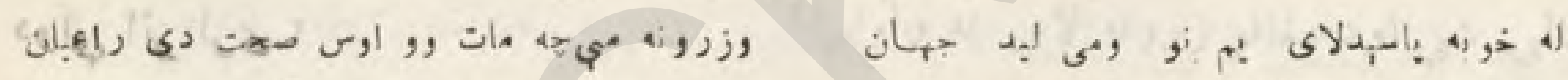

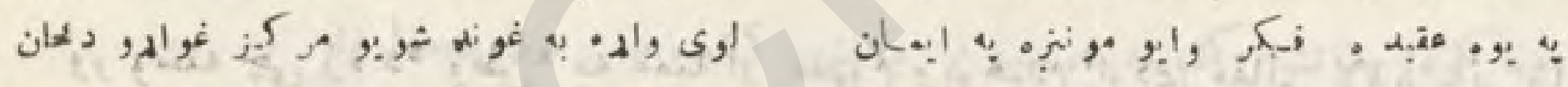

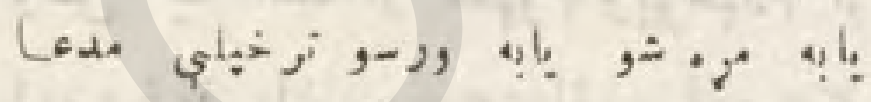

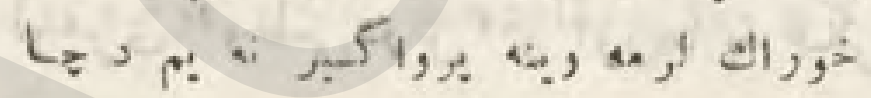

(9) क

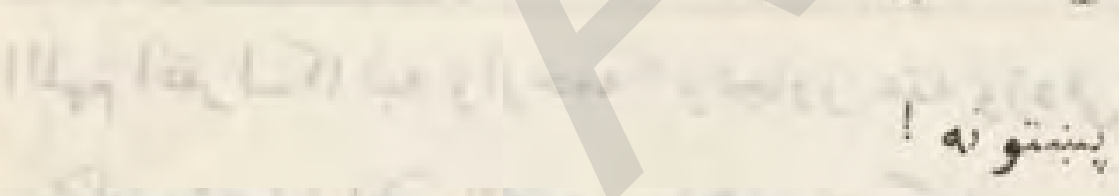

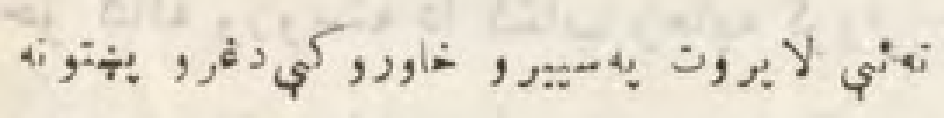

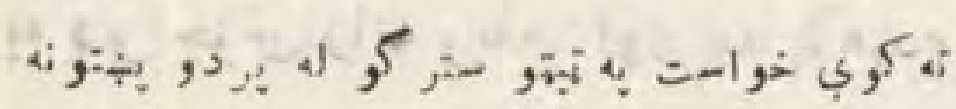

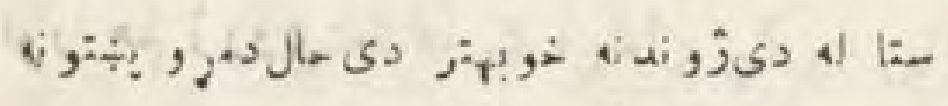

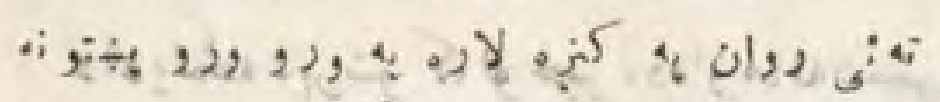

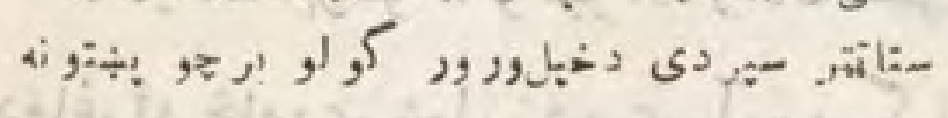

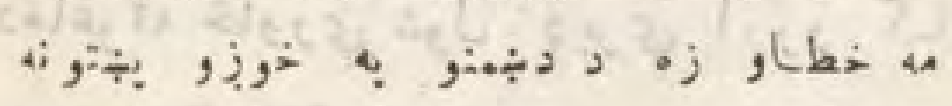

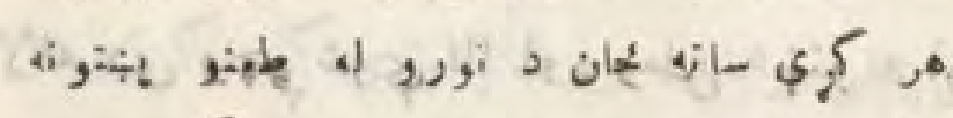

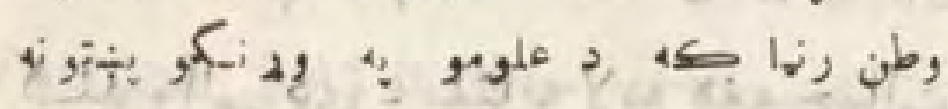

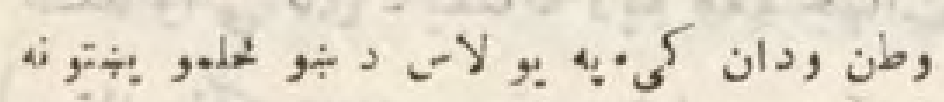

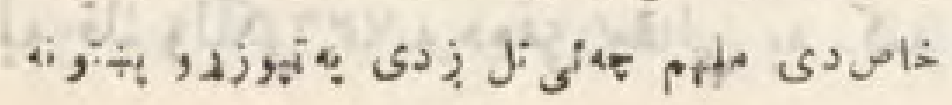

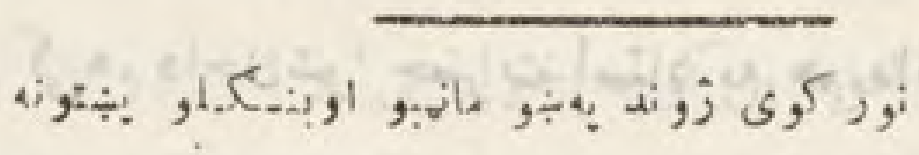

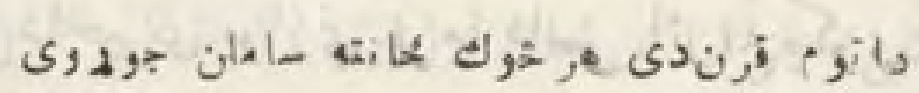

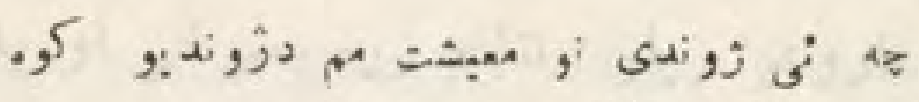
:

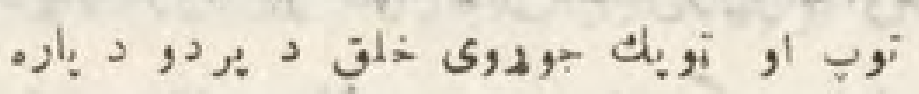

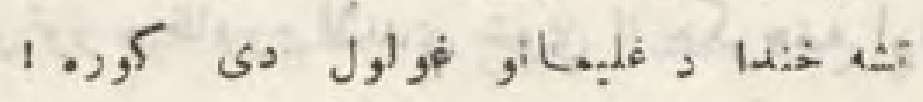

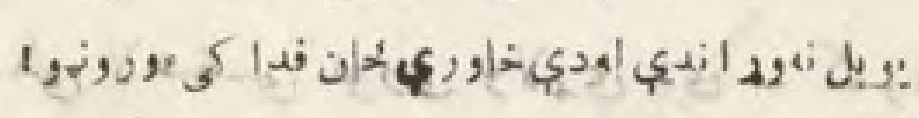

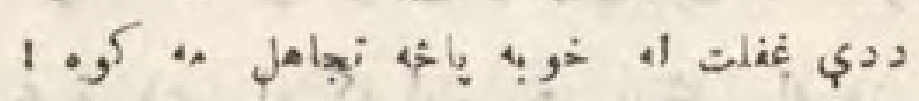

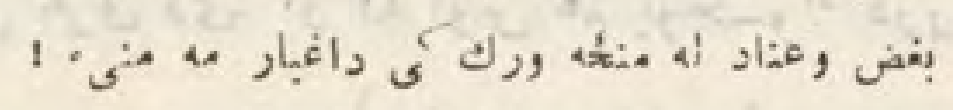

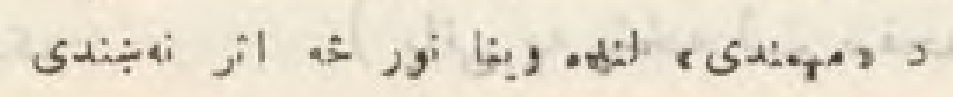




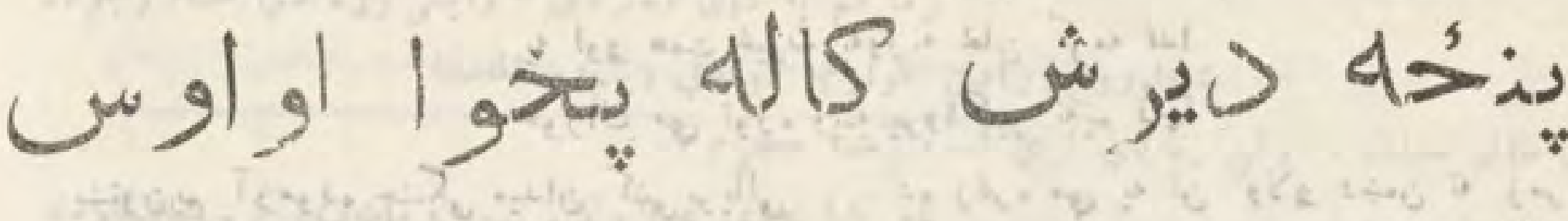

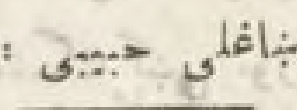

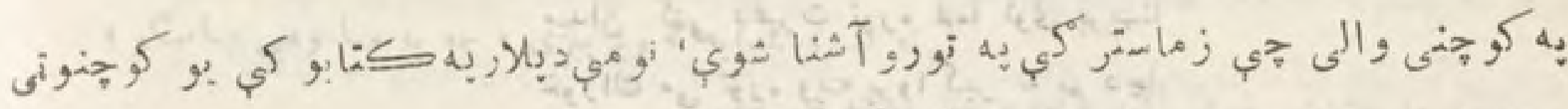

2.

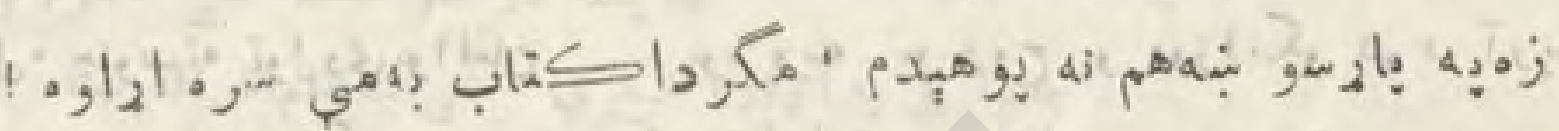

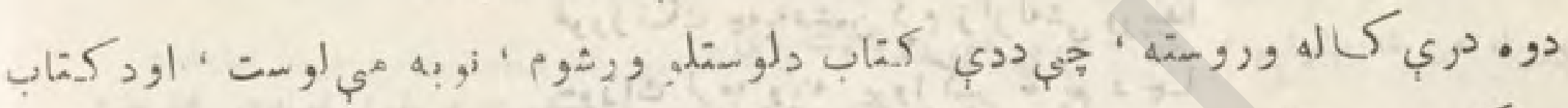

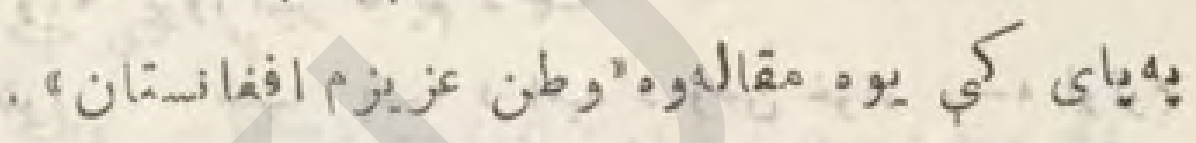

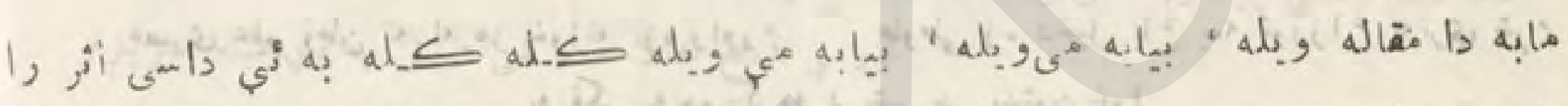

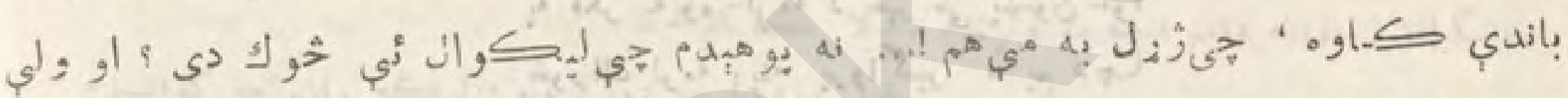

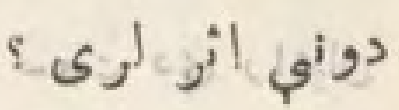

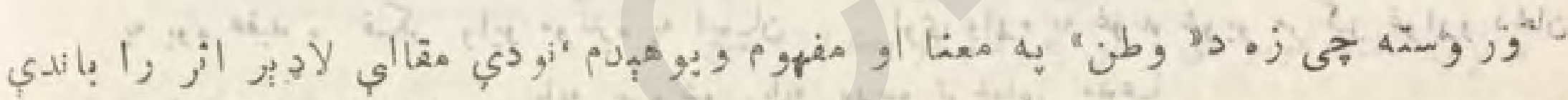

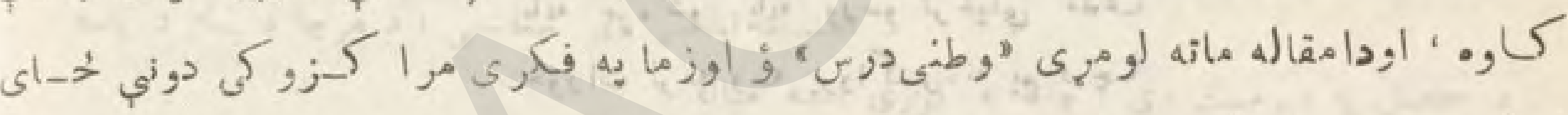

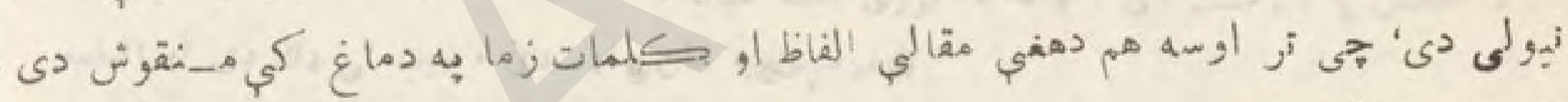

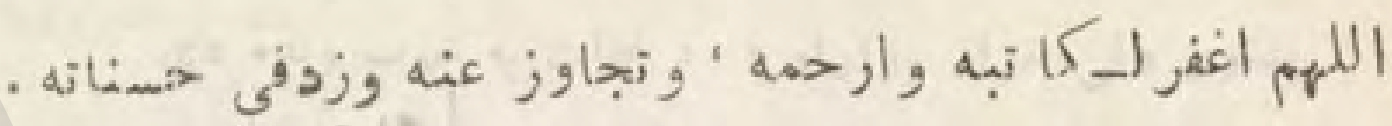

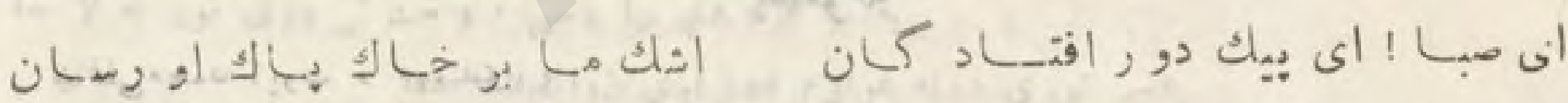

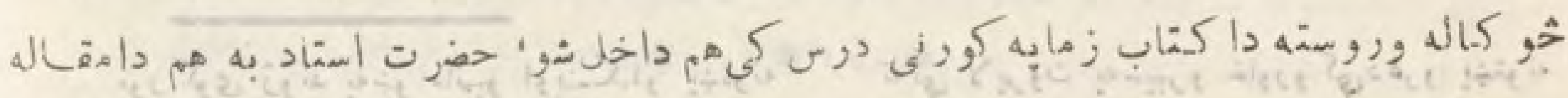

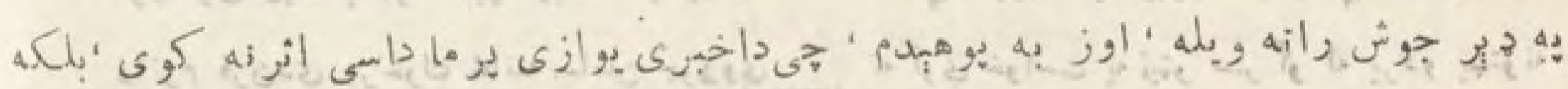
نو

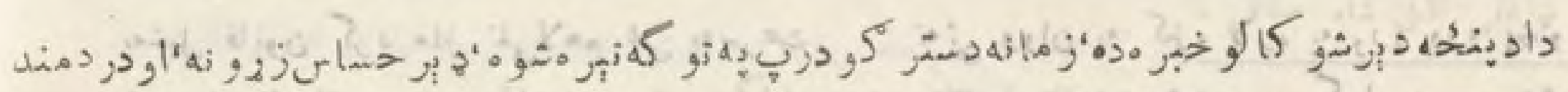

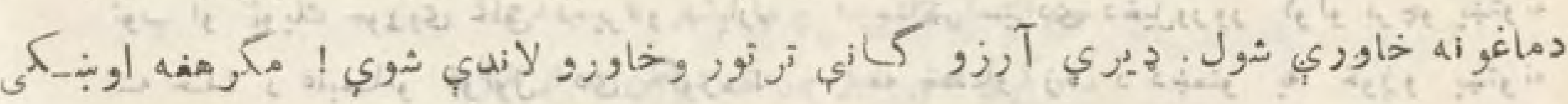

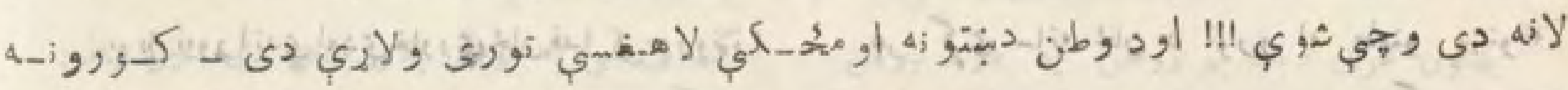

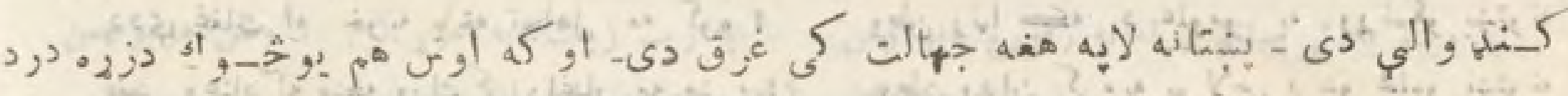

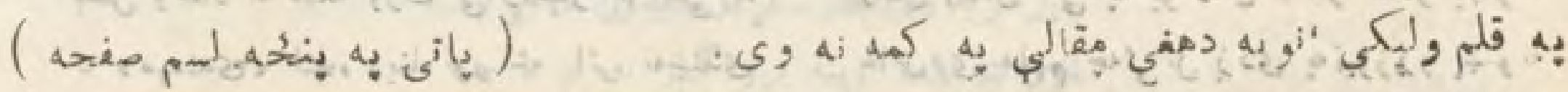




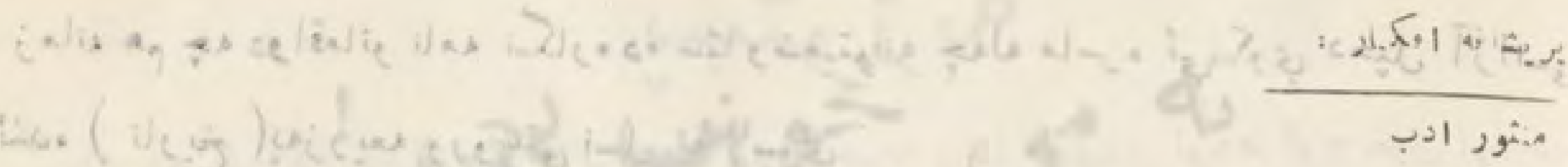

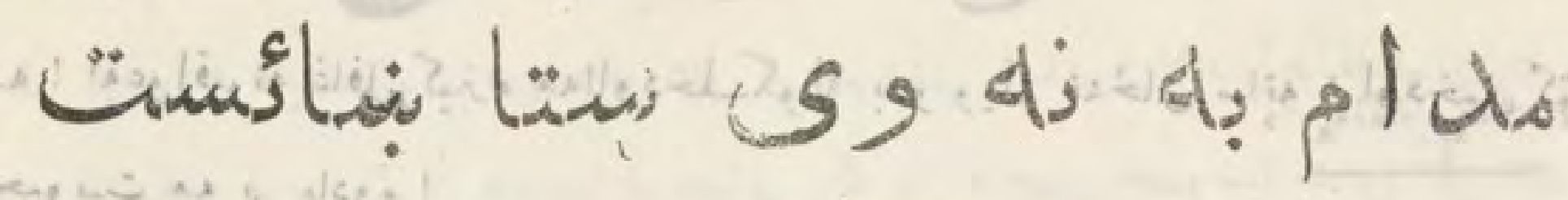

$$
\text { I a g g loj }
$$

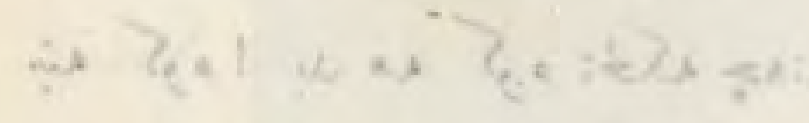

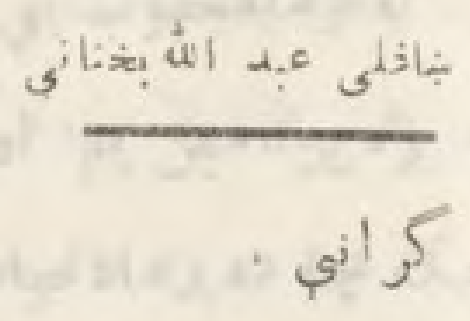

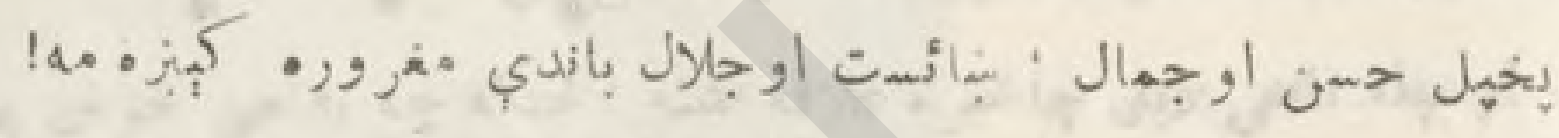

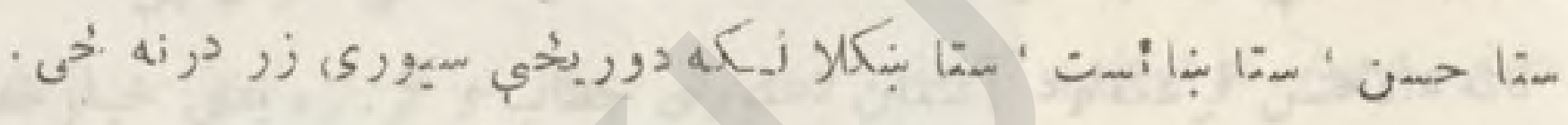

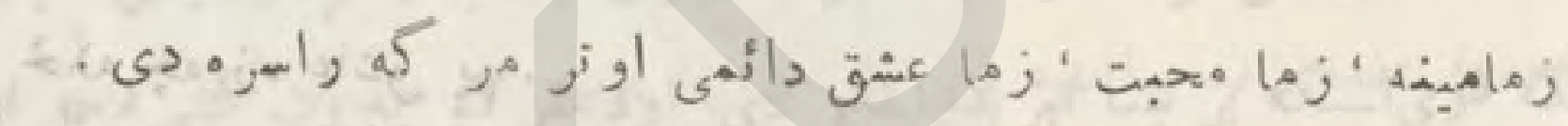

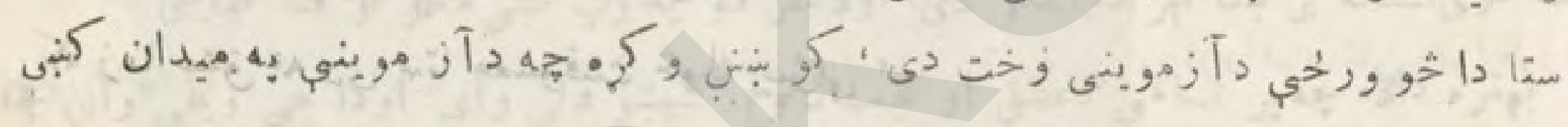

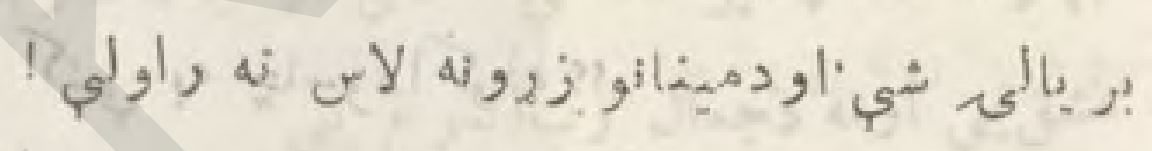

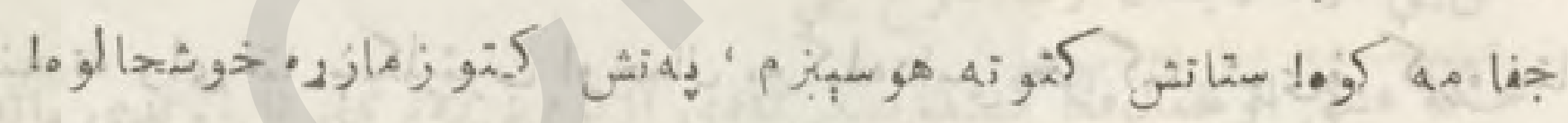

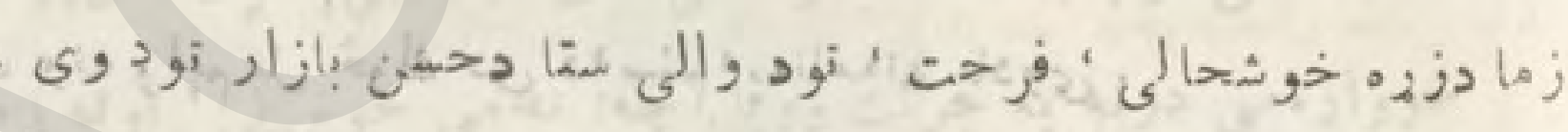

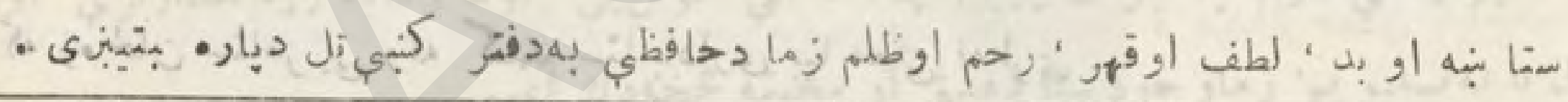

$$
(\text { ilis }
$$

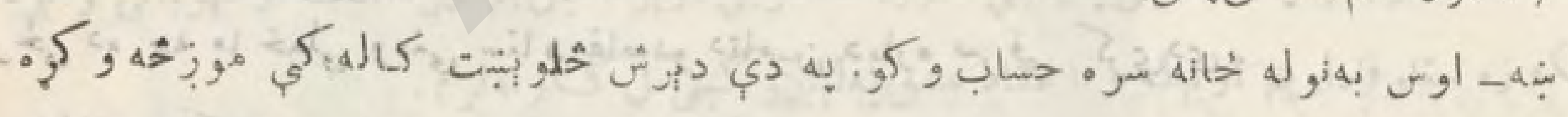

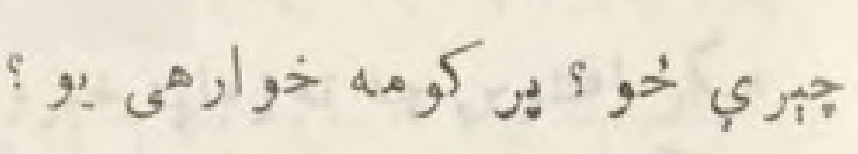

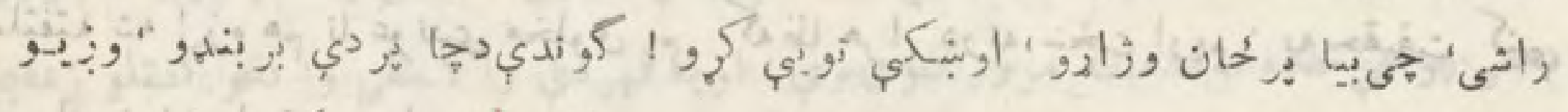

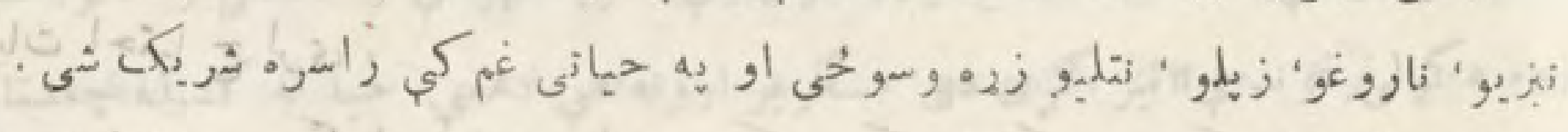

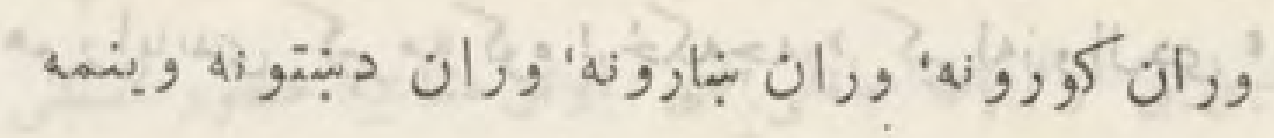

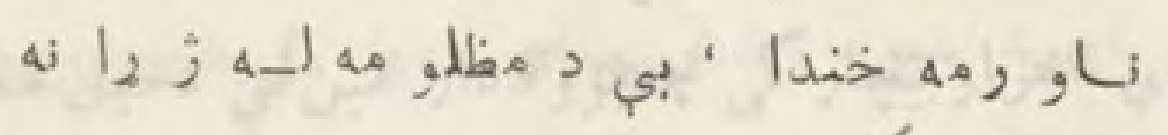

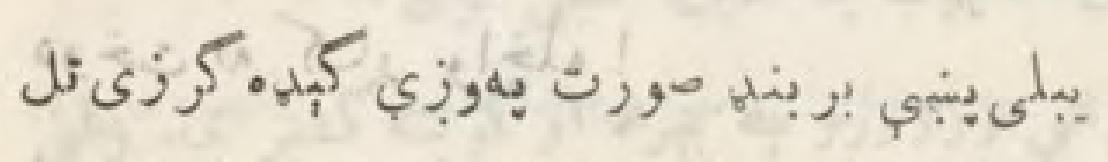

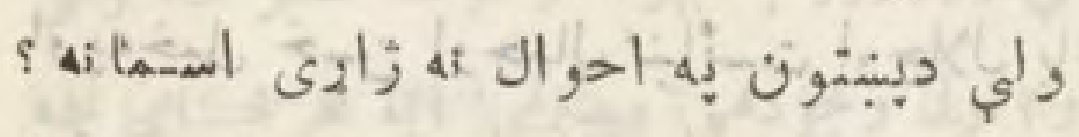

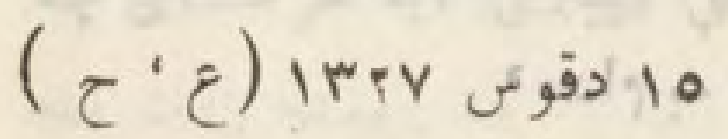




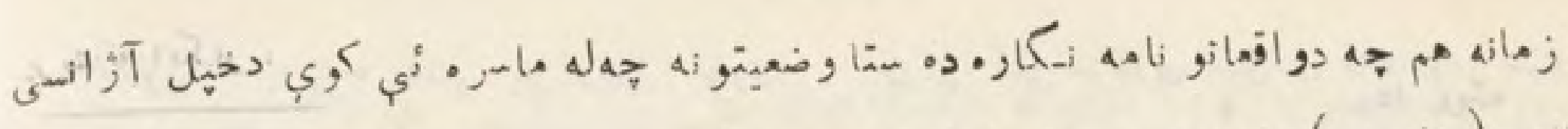

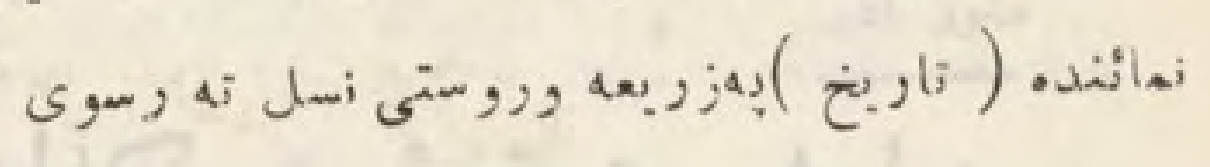

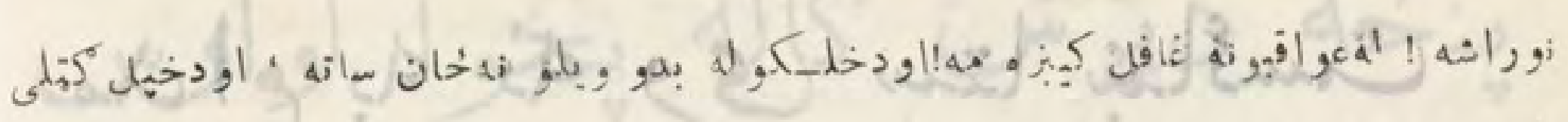

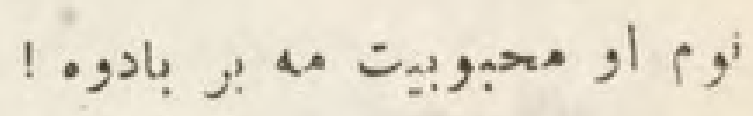

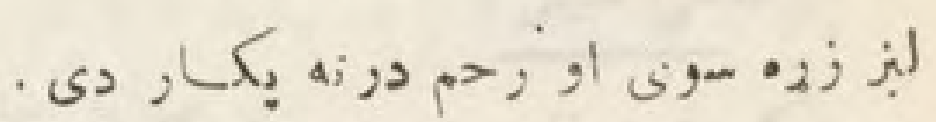

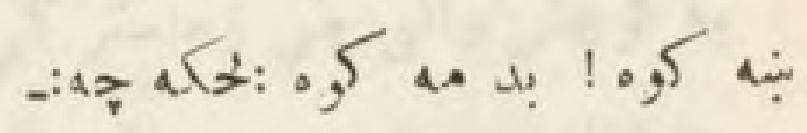

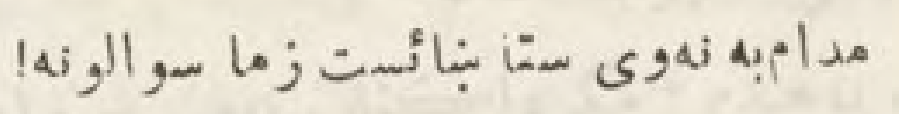

(2) 8

\begin{abstract}
जis

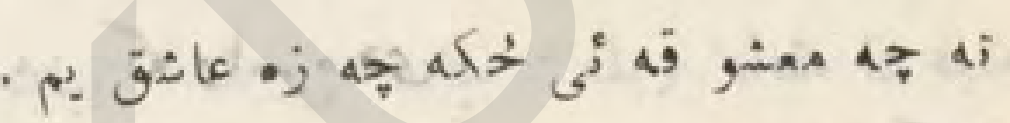

?
\end{abstract}

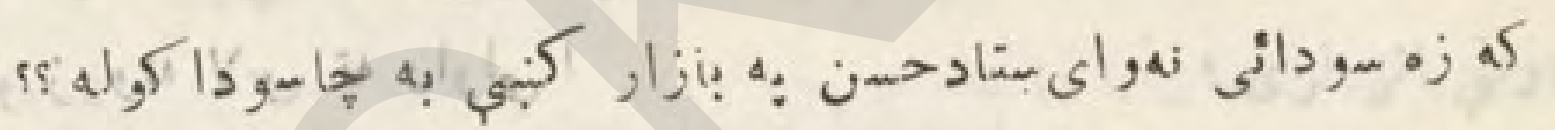

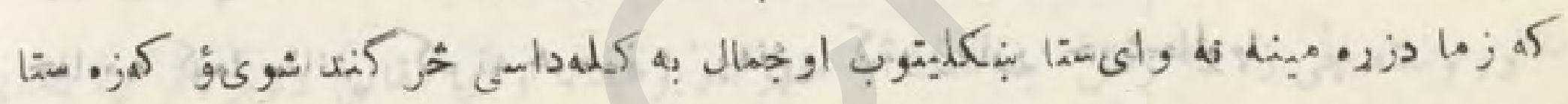

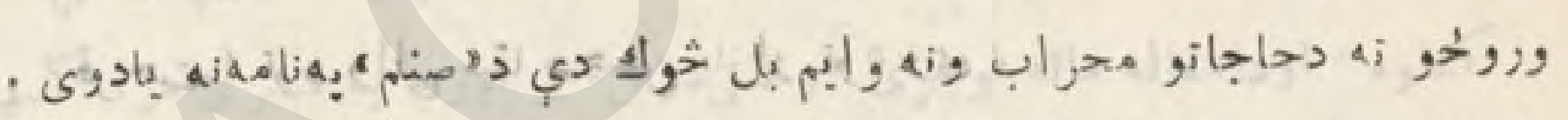

- Ja ja

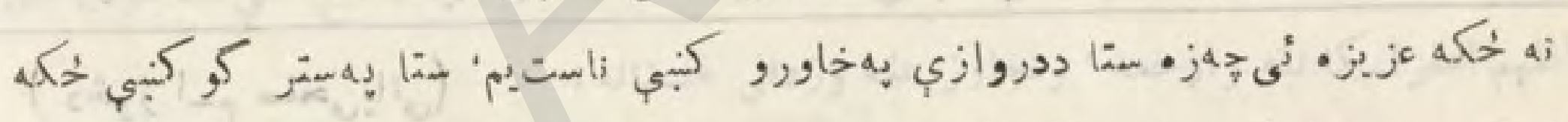

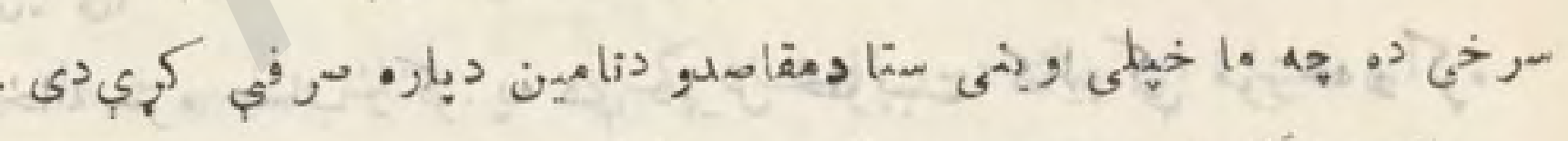

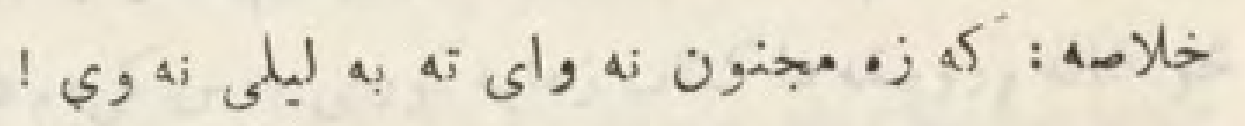

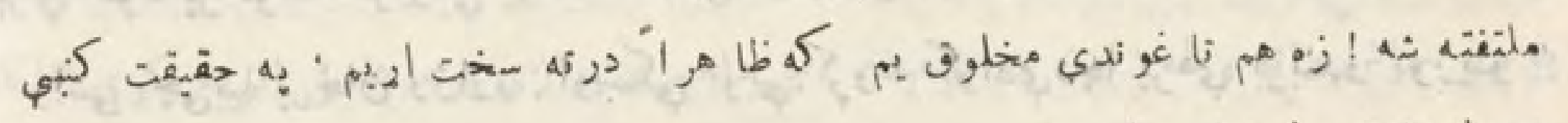

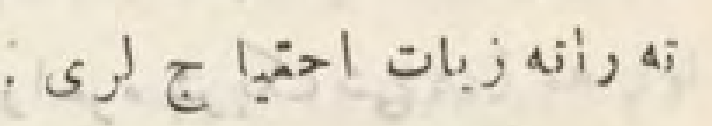

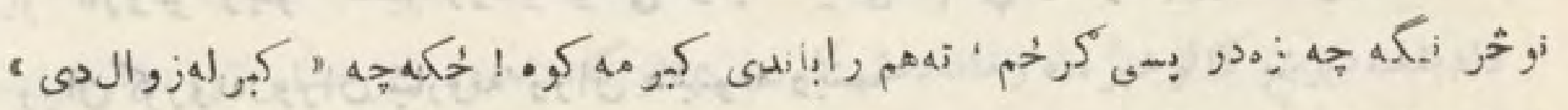

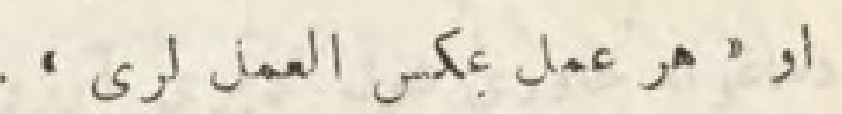

$$
\begin{aligned}
& \text { ! ا }
\end{aligned}
$$

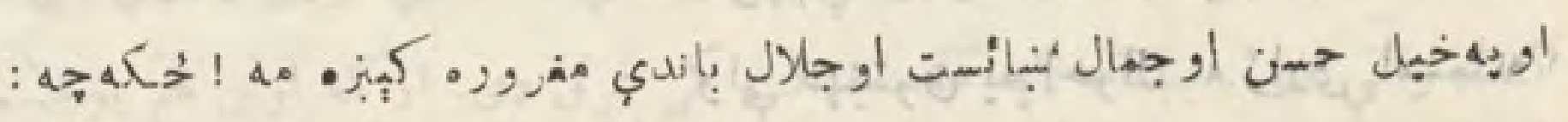

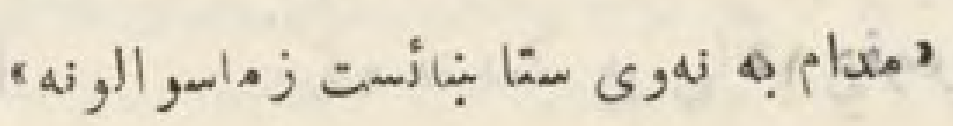


( IV)

\section{!}

$$
\begin{aligned}
& \text { - }
\end{aligned}
$$

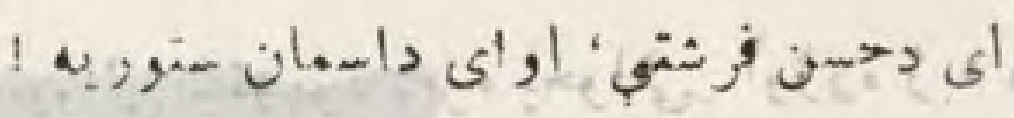

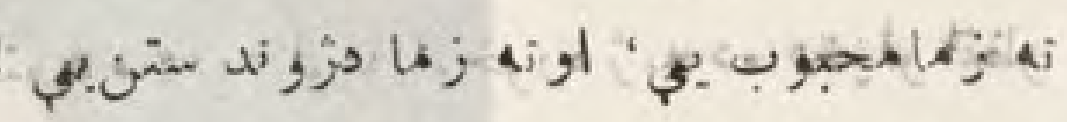

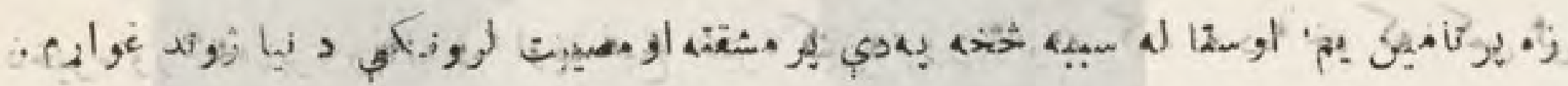

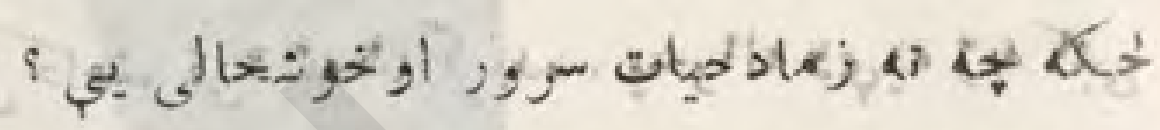

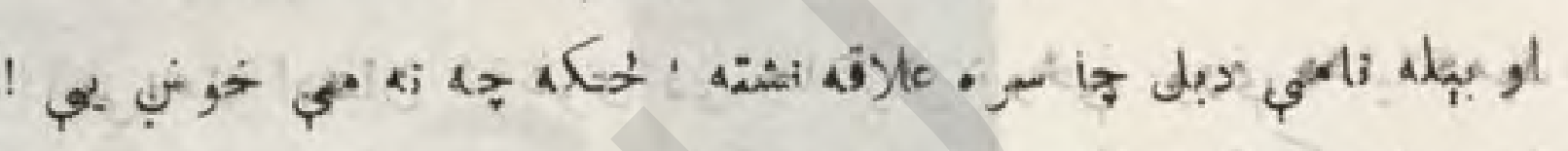

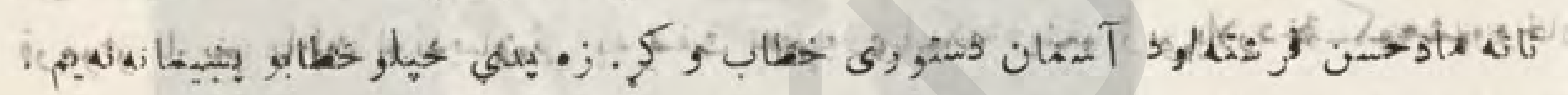

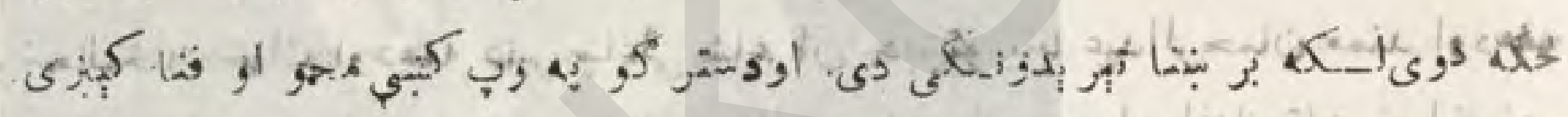

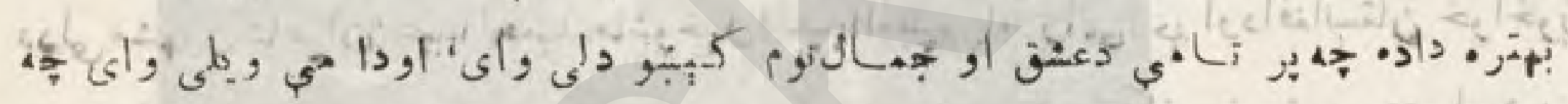

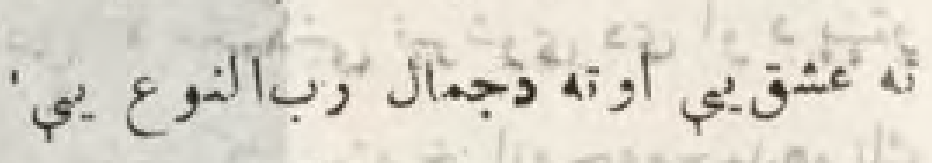

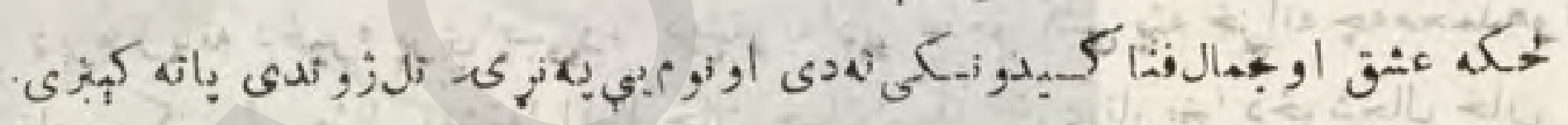

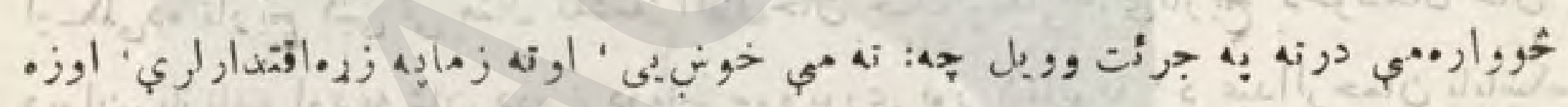

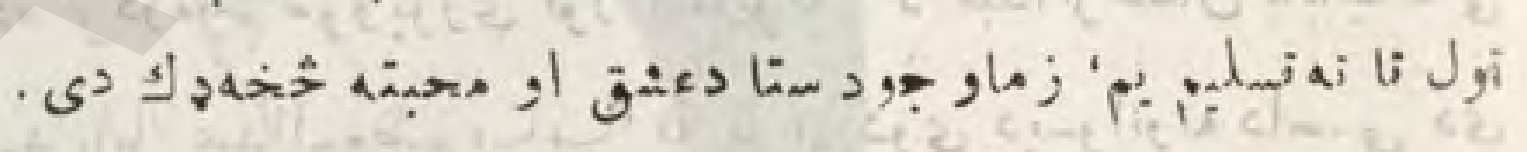
-

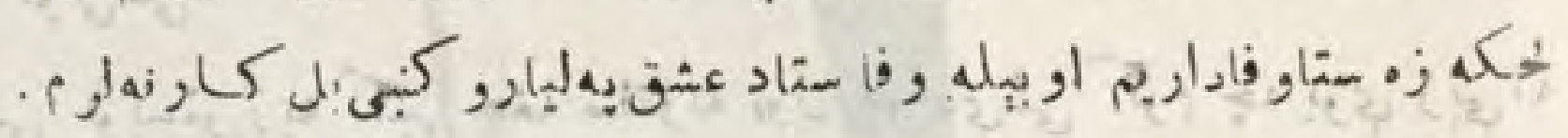

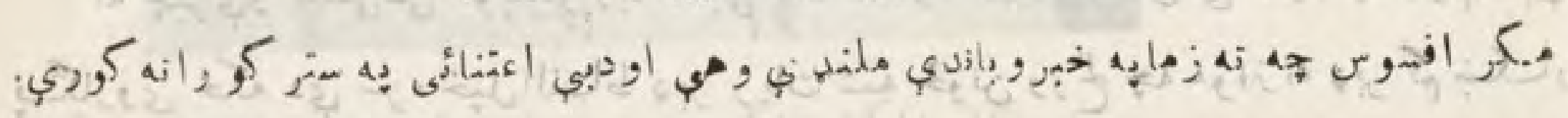

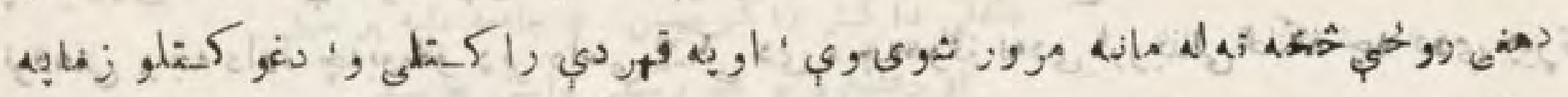

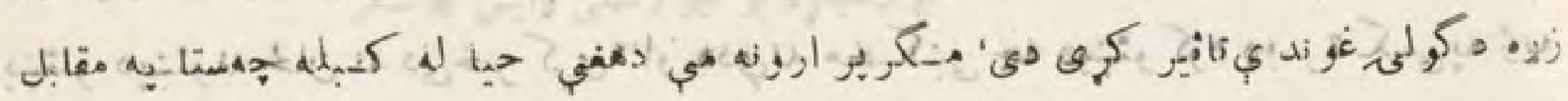

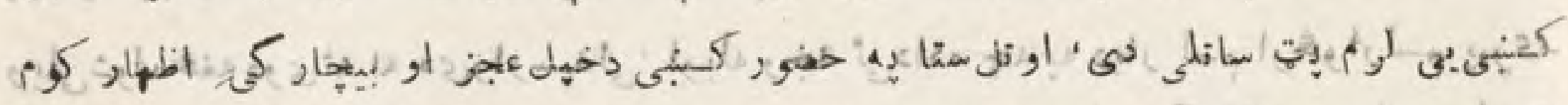

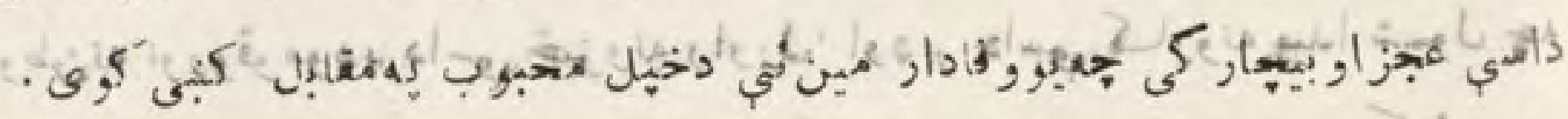

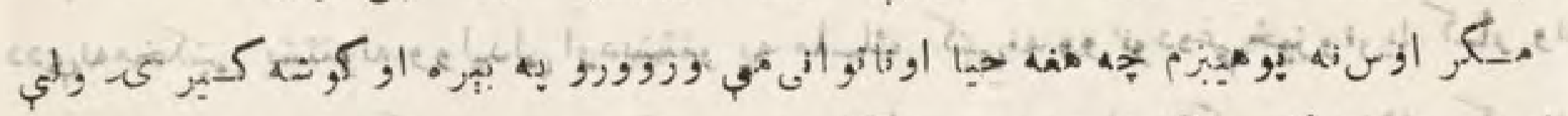

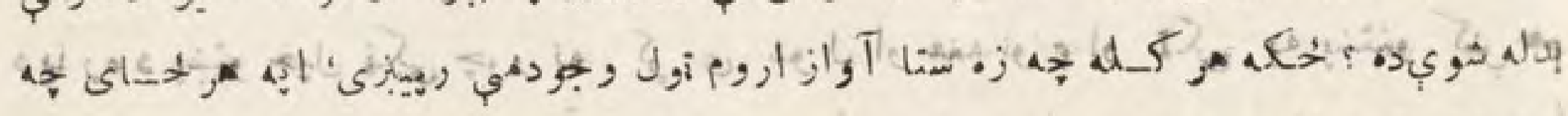

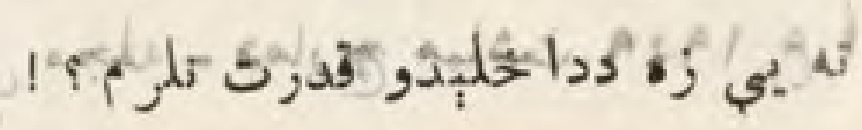




\section{4. अ g*ivis}

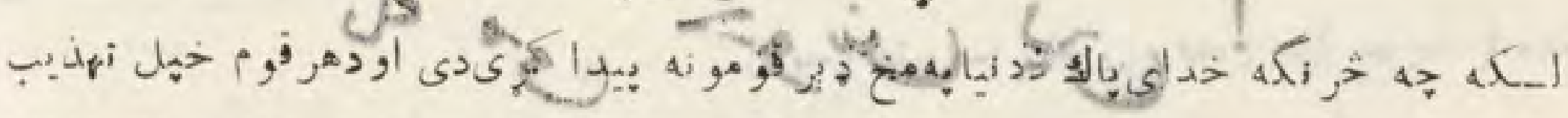

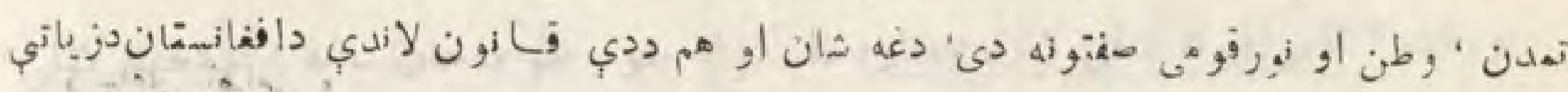

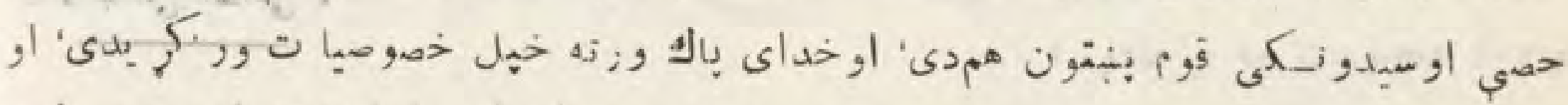

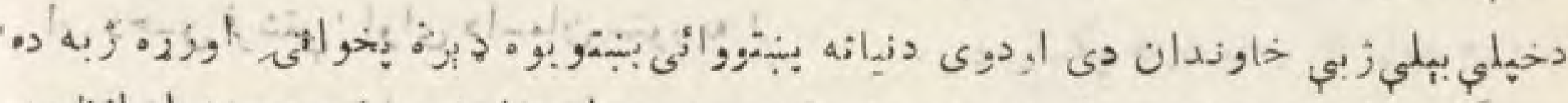

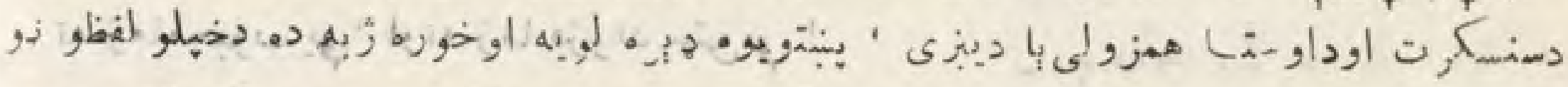

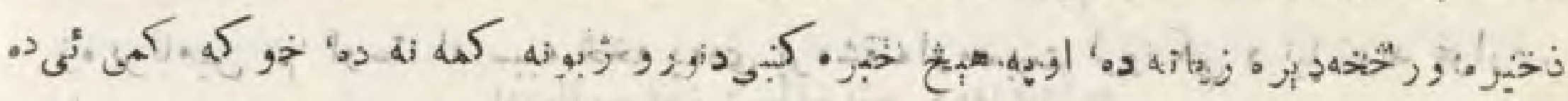

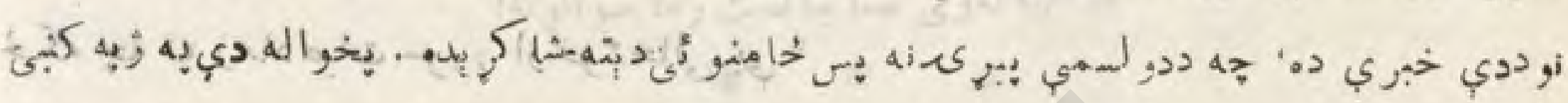

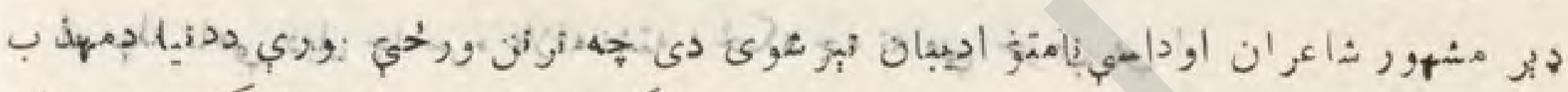

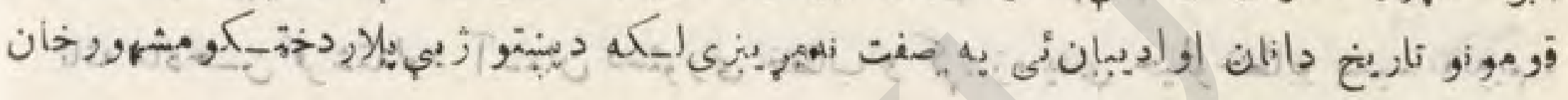

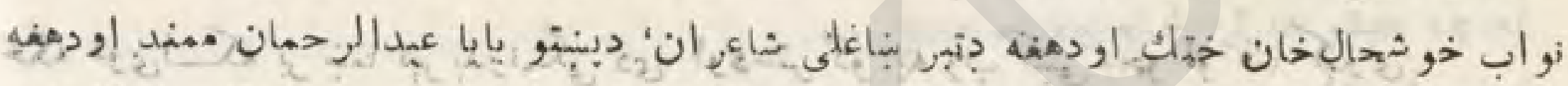

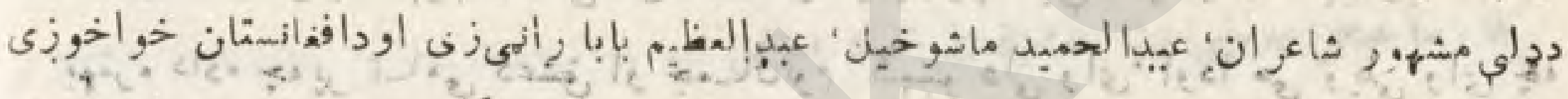

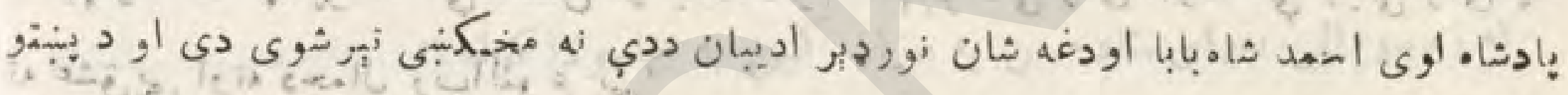

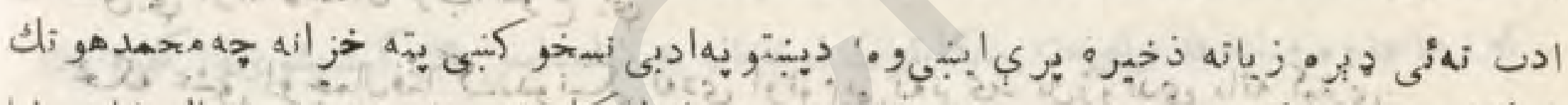

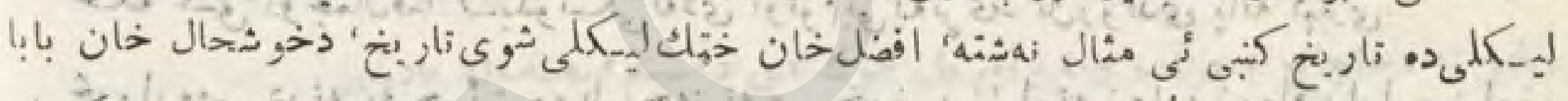

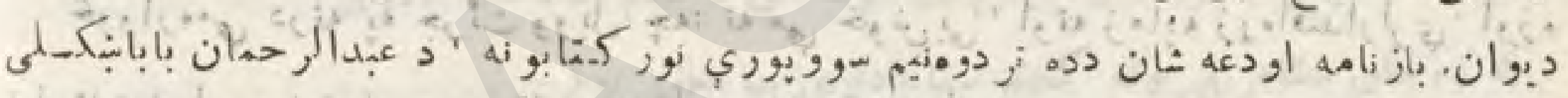

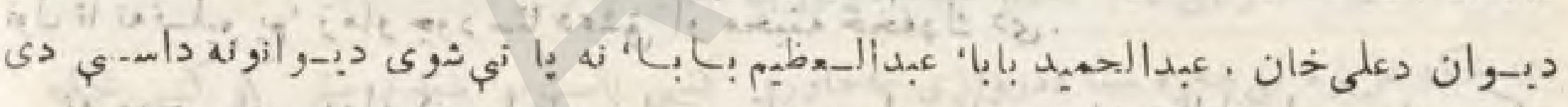

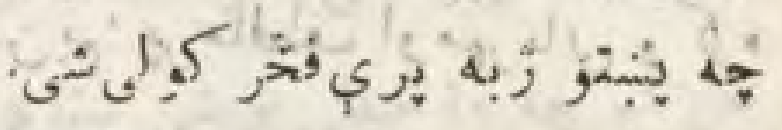

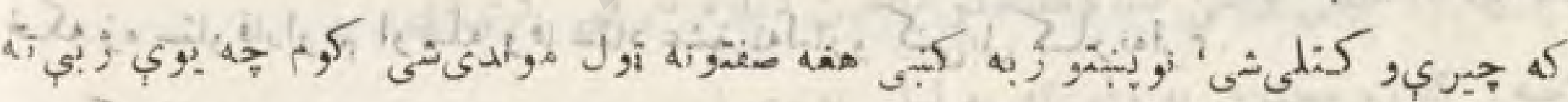

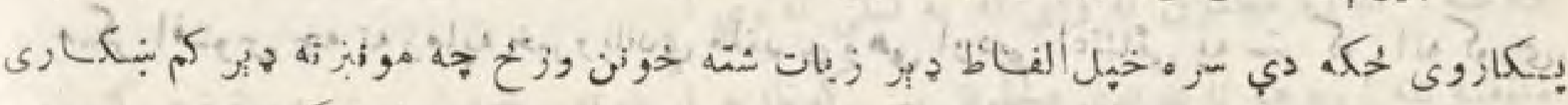

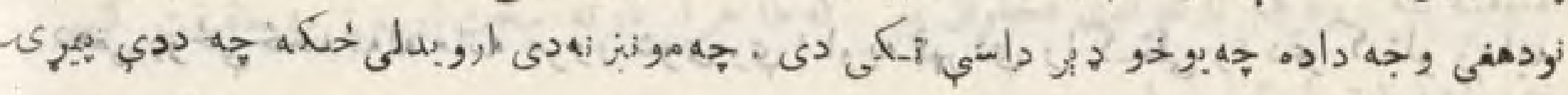

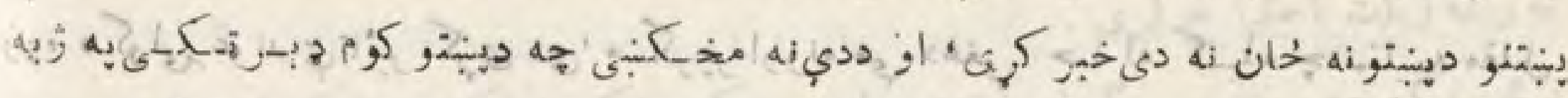

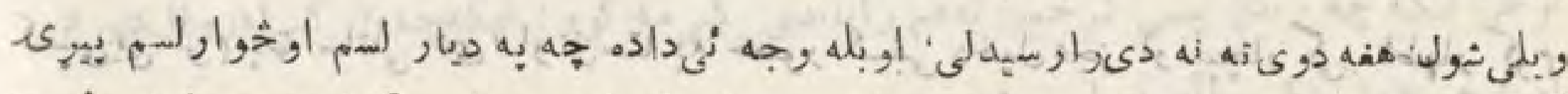

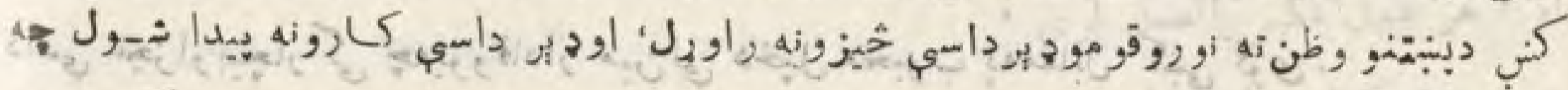

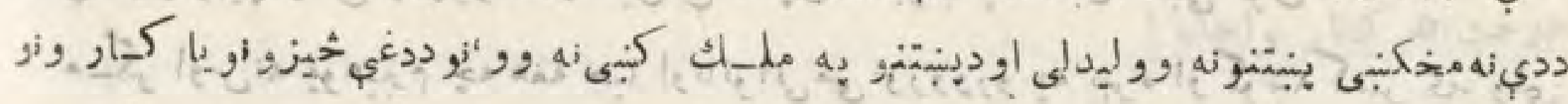

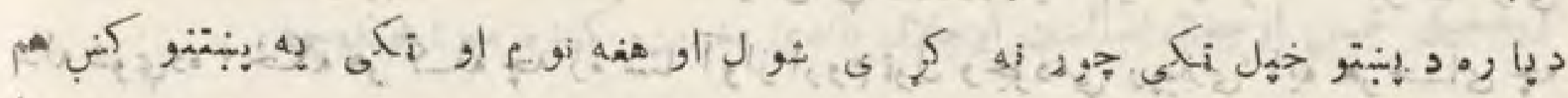

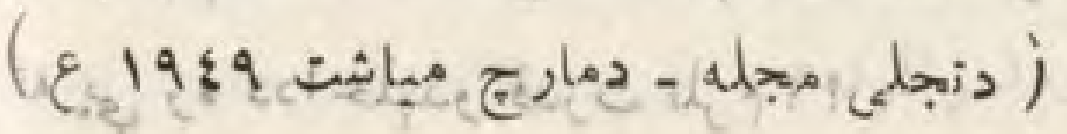
ش 


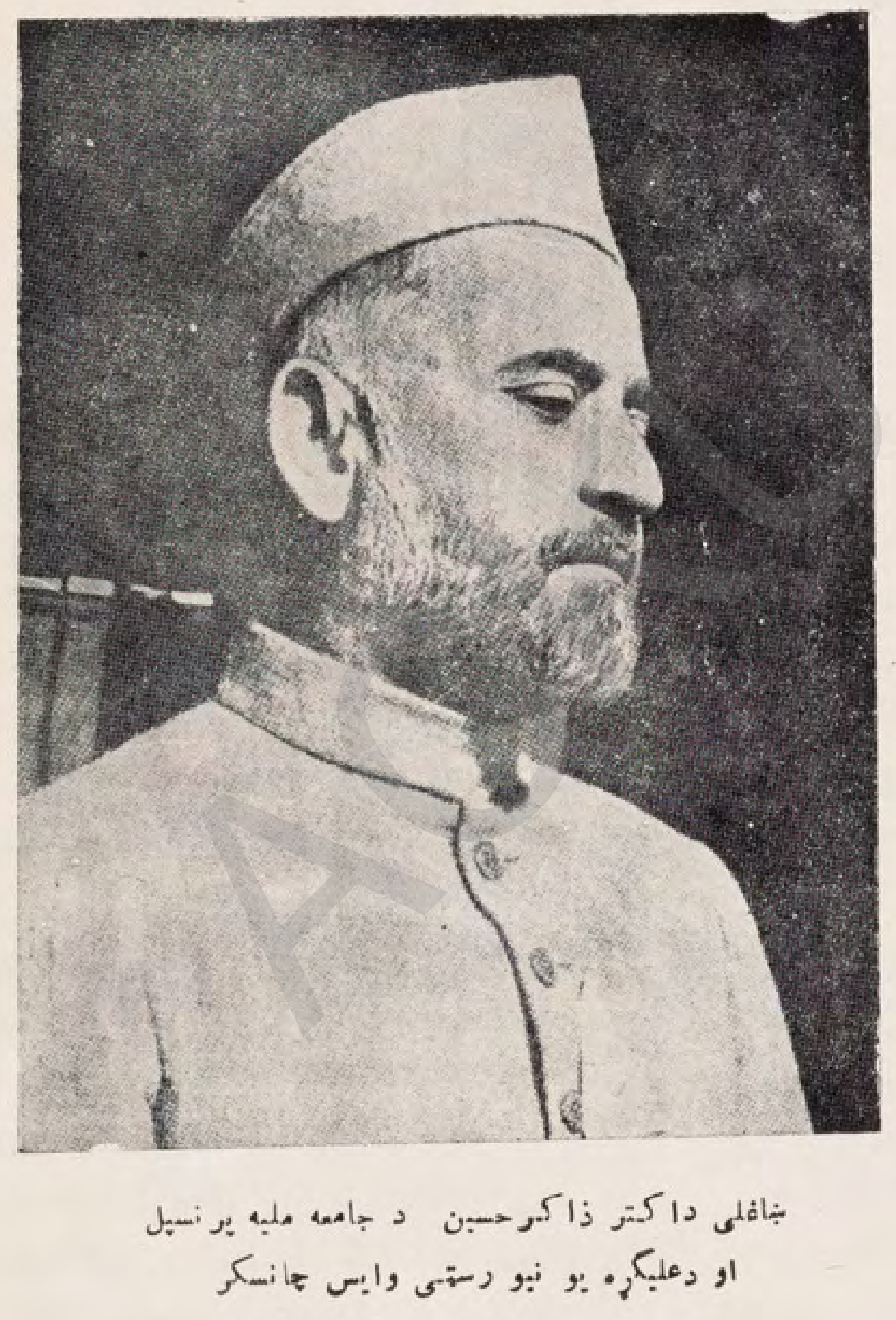




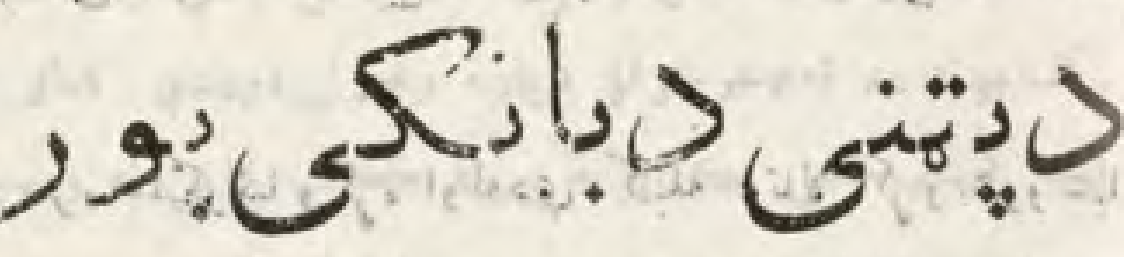

$$
\text { ذبناف }
$$

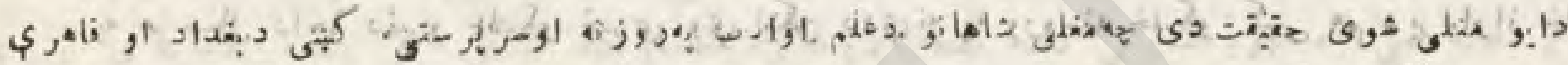

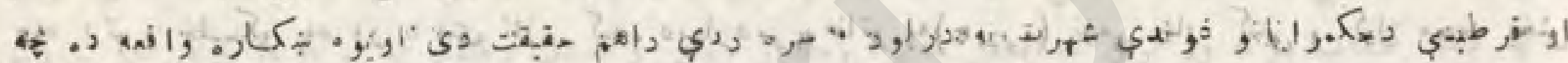

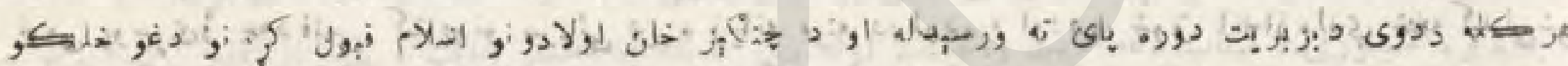

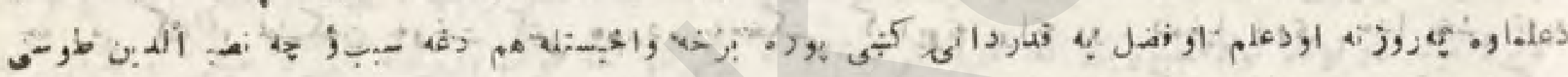

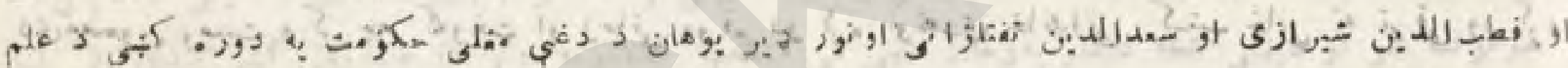

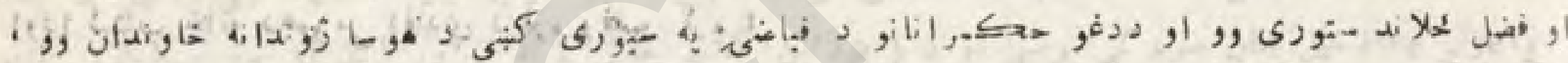

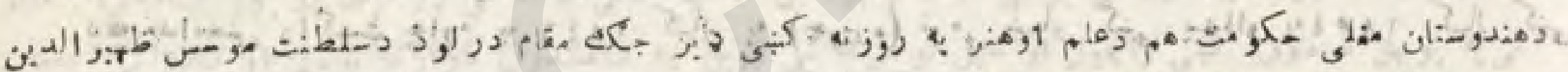

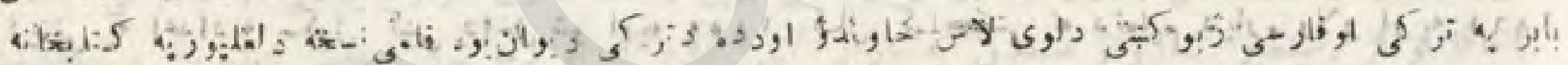

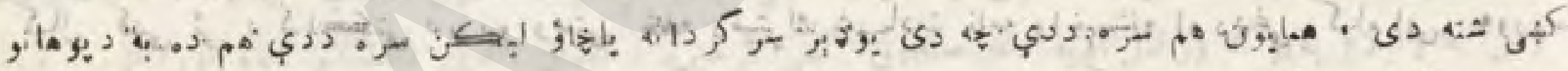
ك

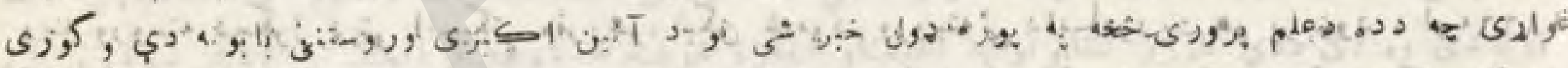

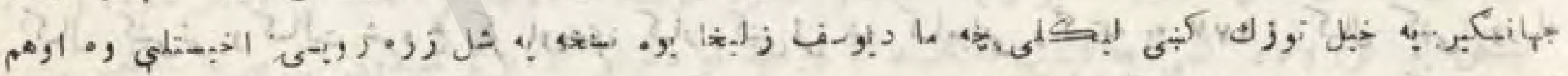

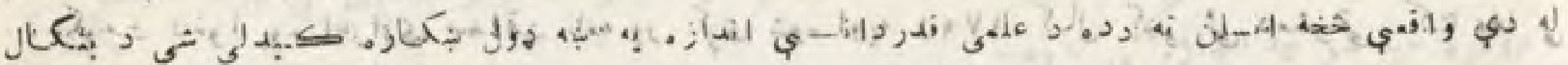

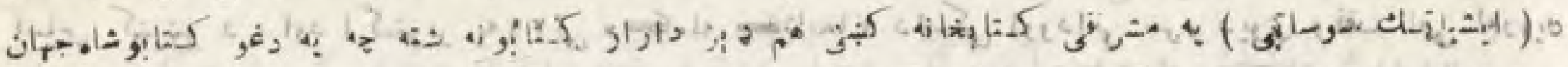

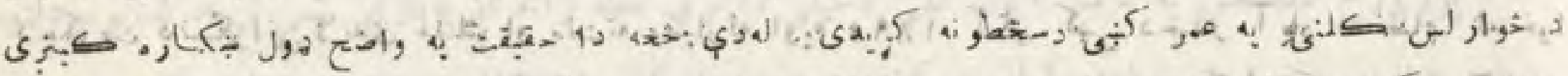

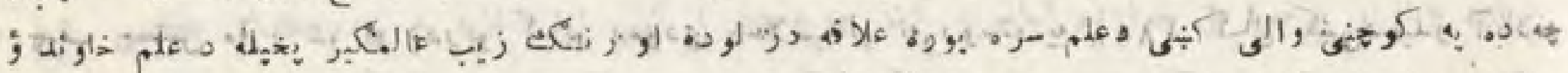

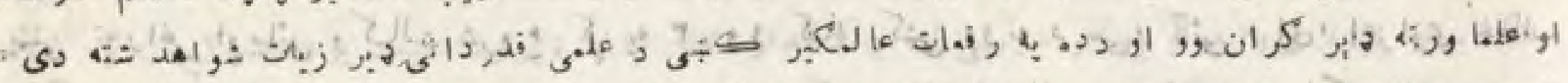

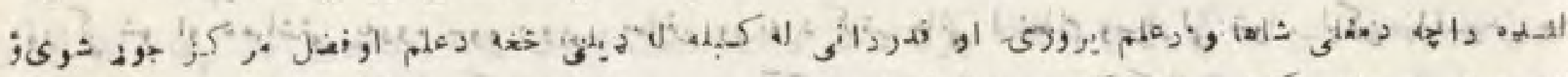

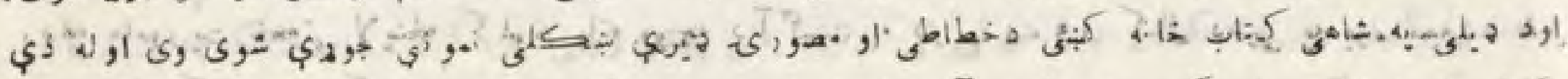

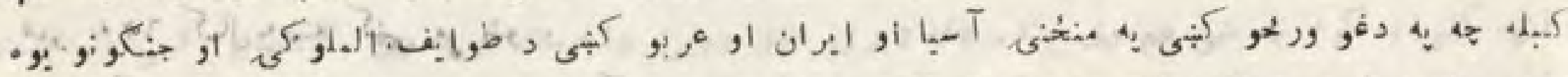

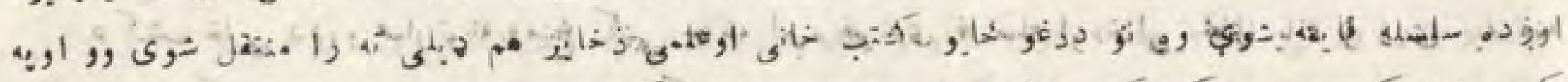

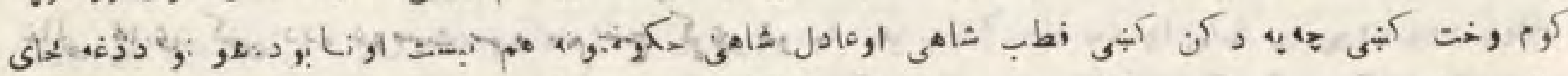
ك: 定, 


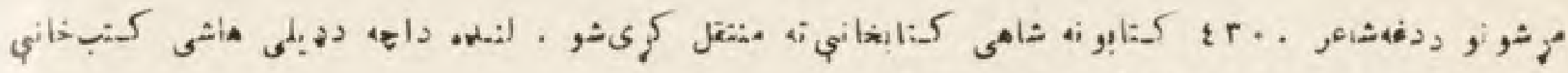

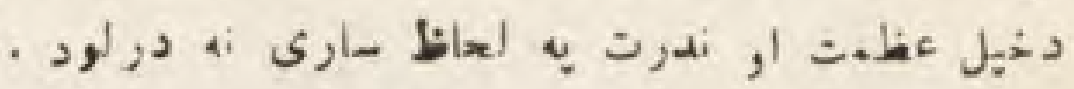

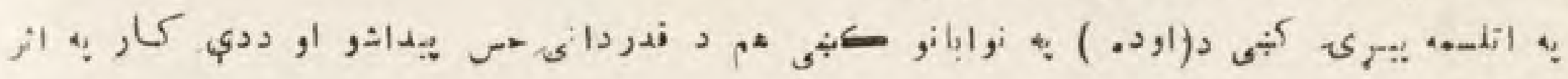

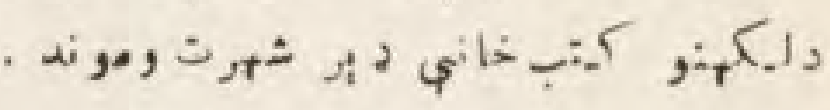

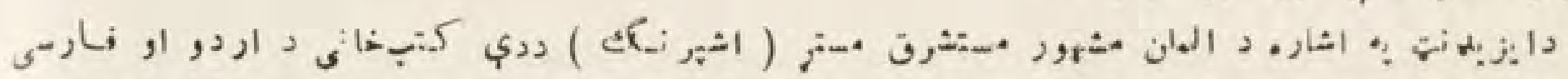

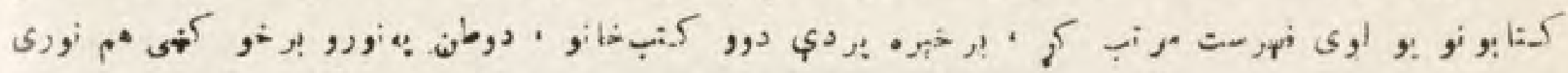

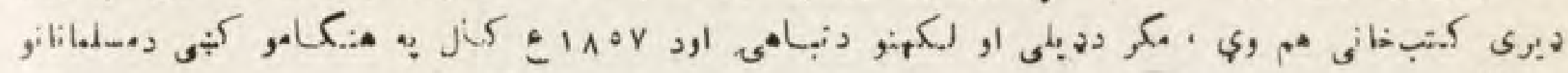
.

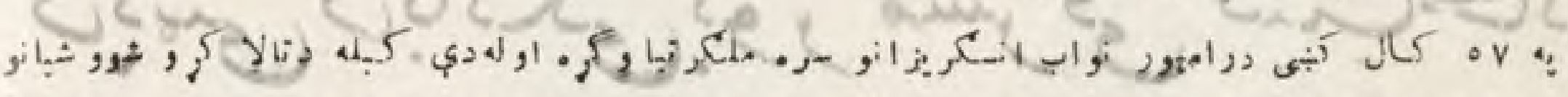

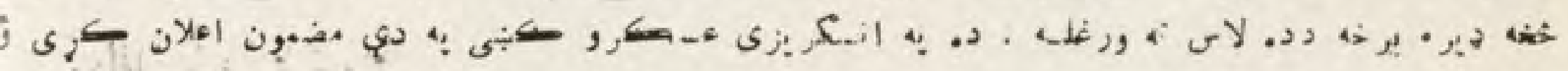

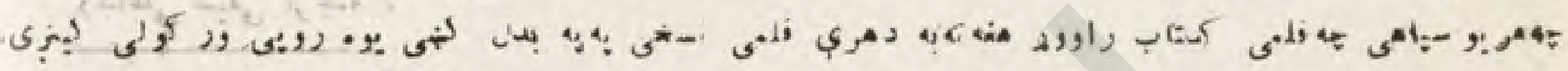

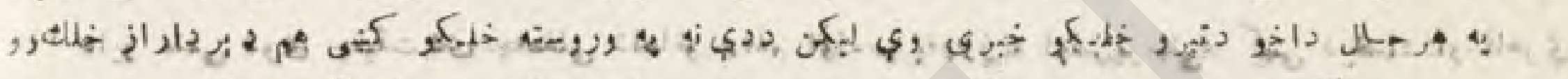

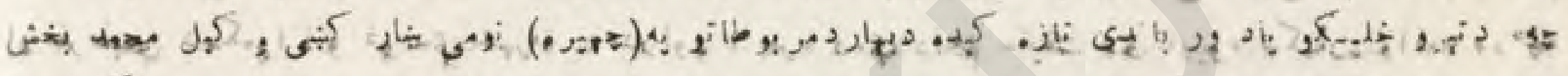

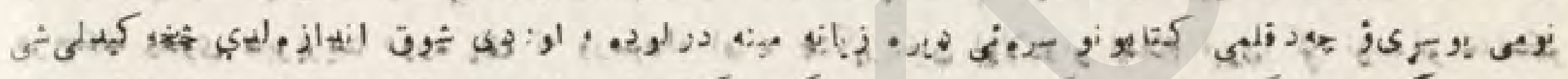
4ti 1.

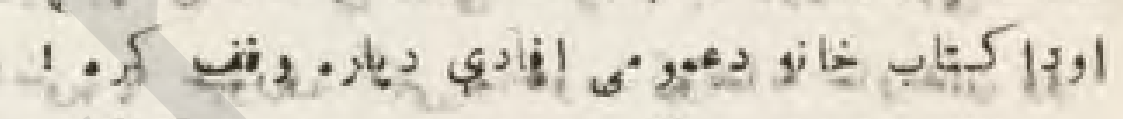
نج

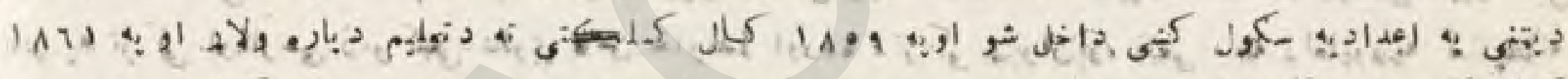

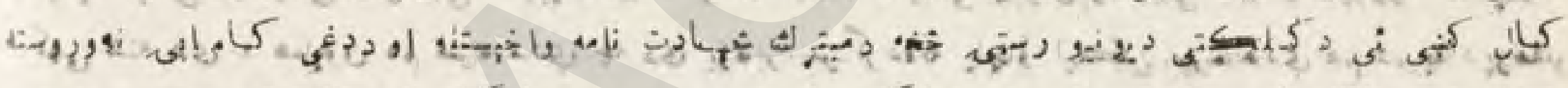

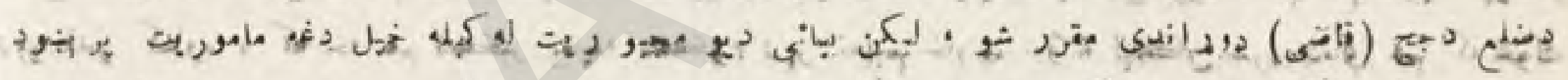

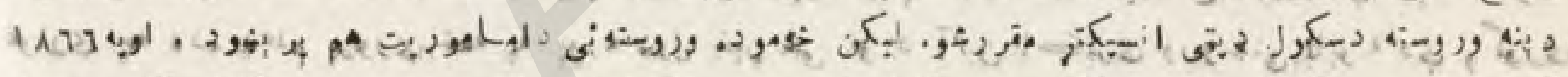

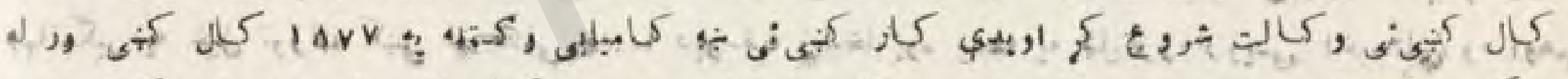

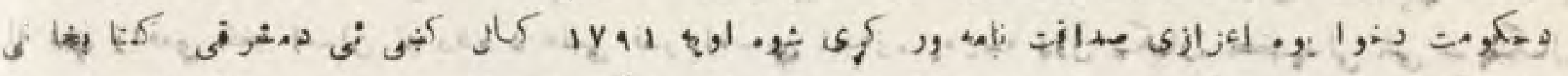

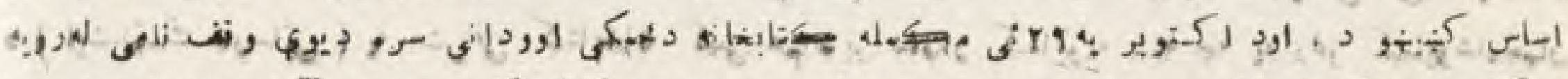

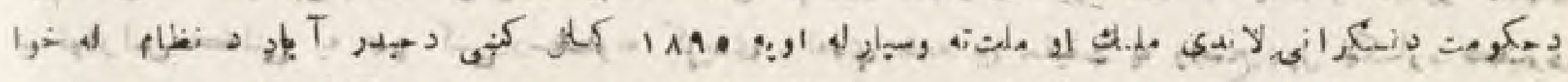
: :

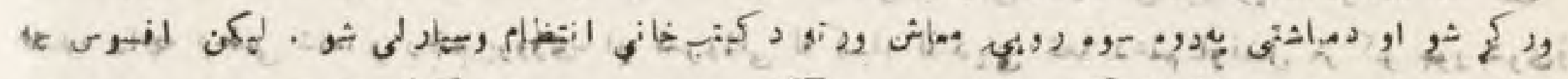
له ن

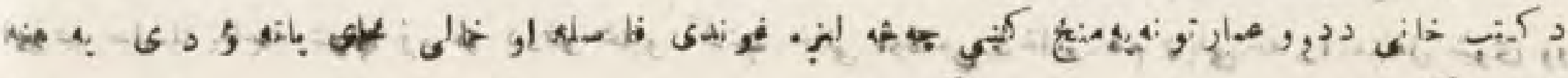

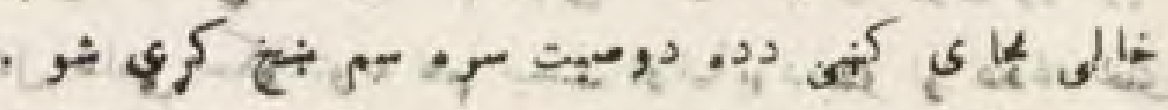

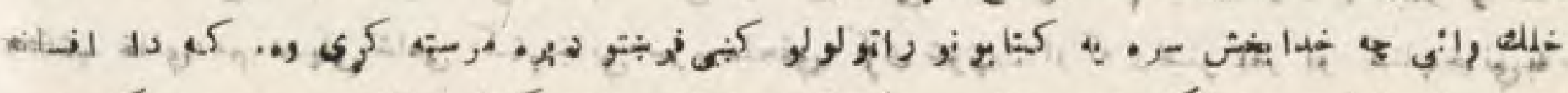

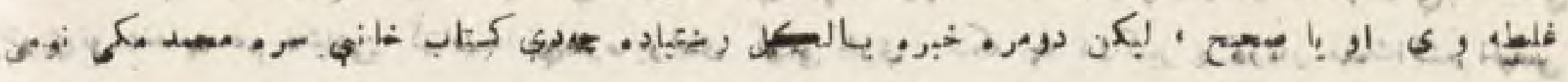




\section{$(r+1)$}

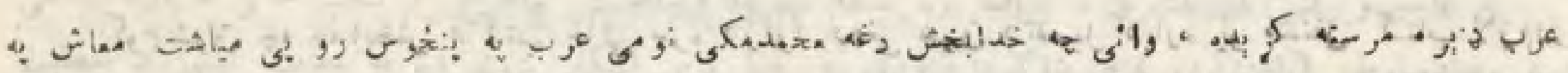

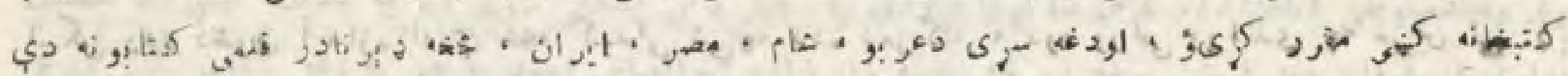
定

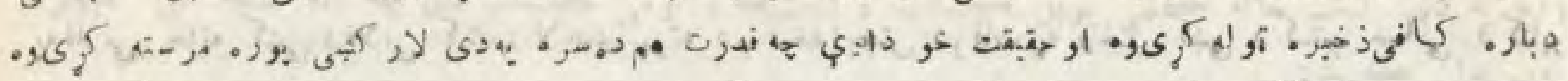

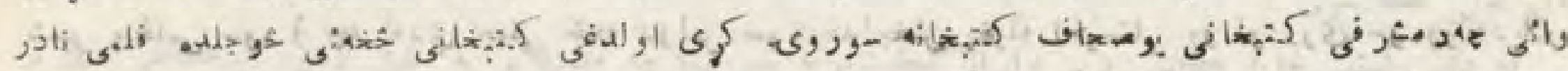

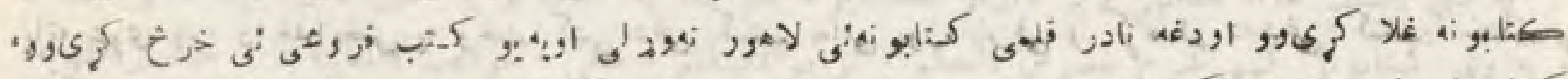

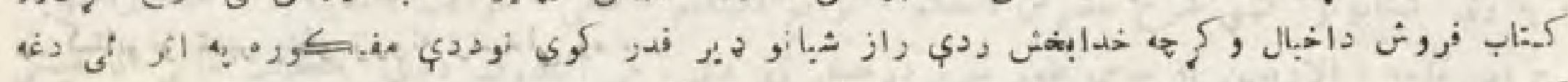

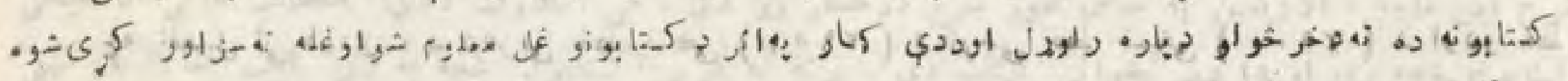

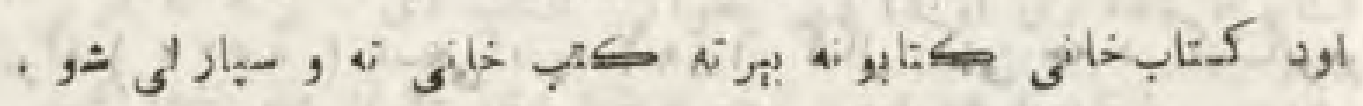

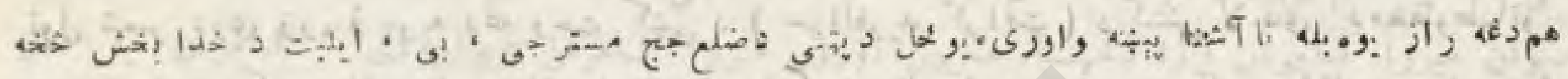

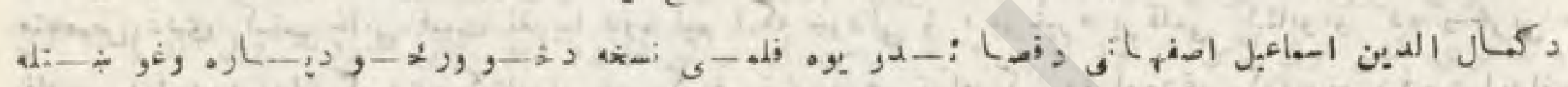
ي,

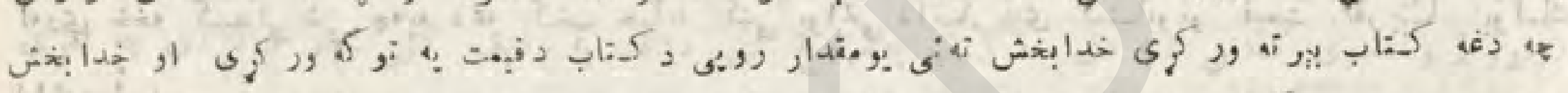

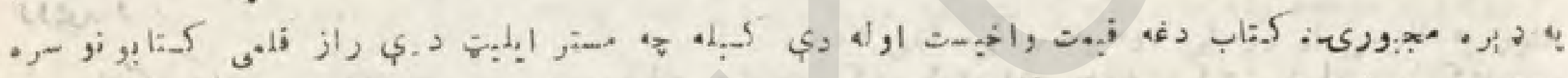
a

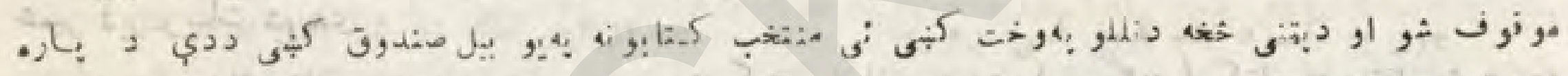

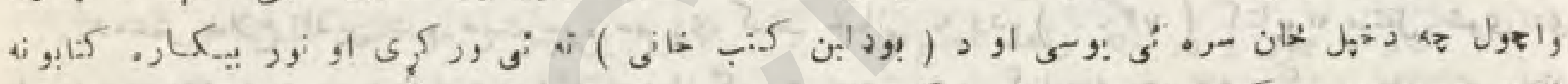

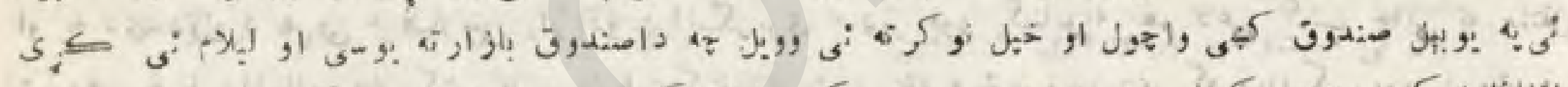

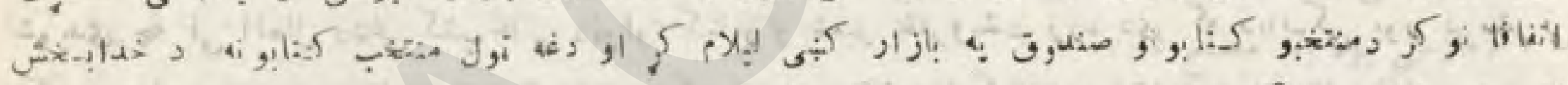

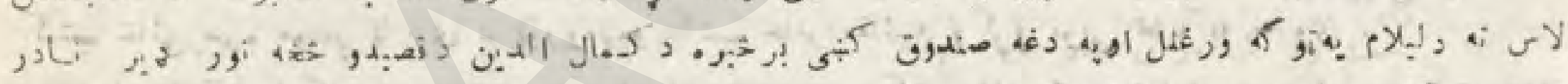

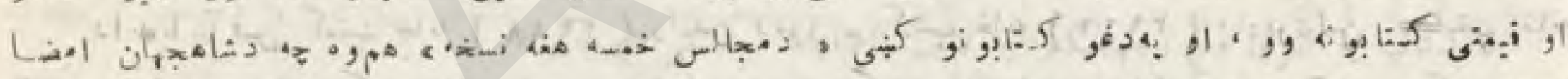

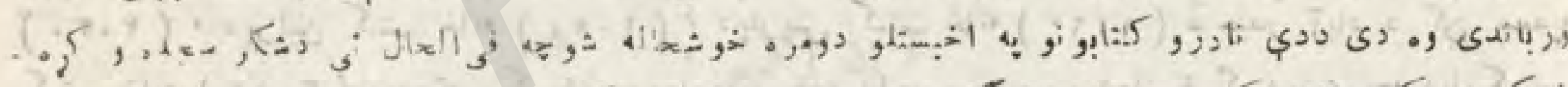
, ب.

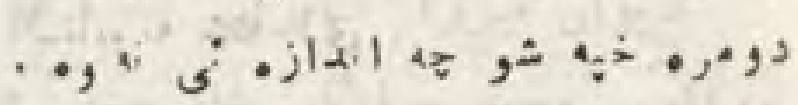

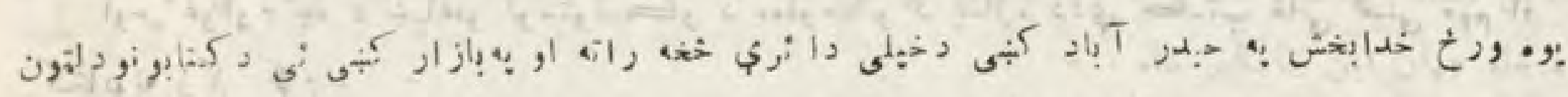

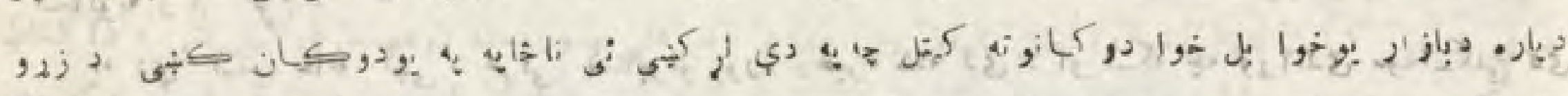

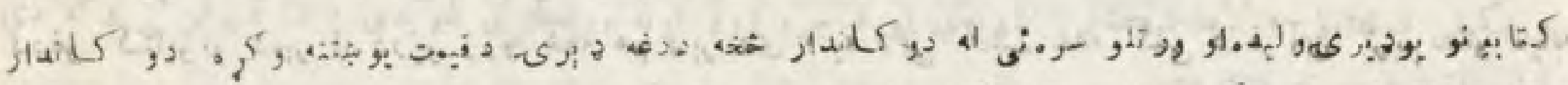

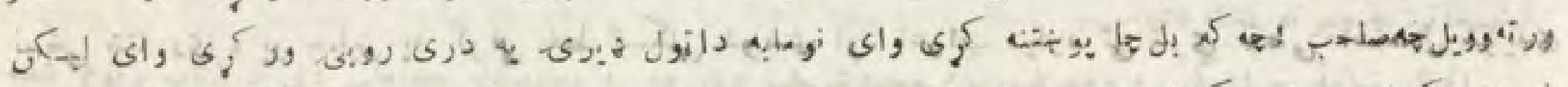

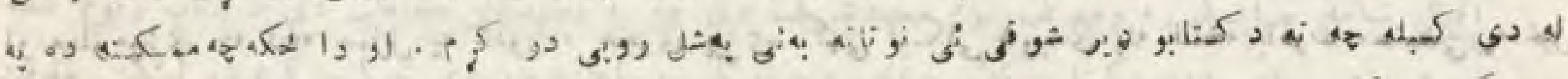

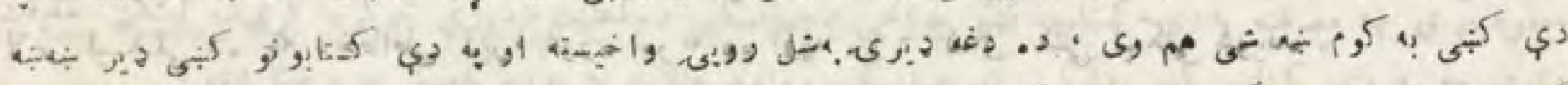

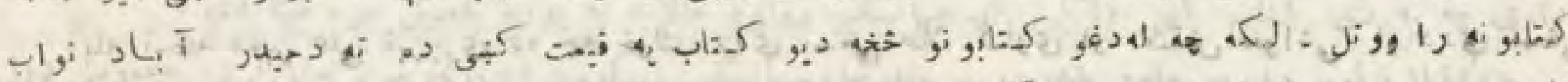

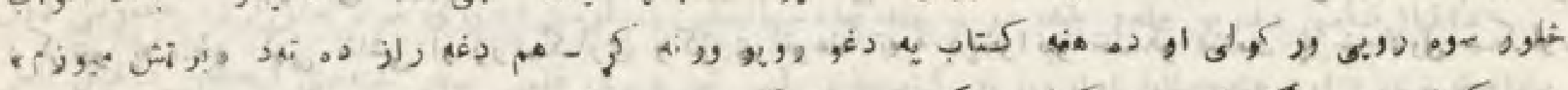

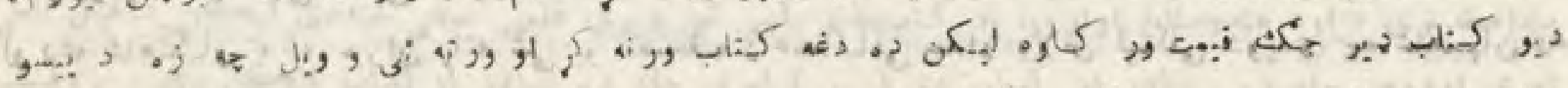

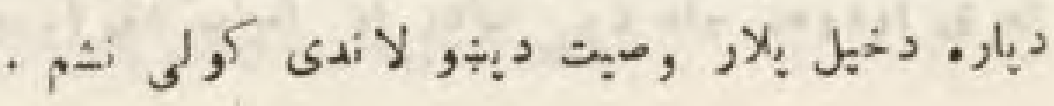




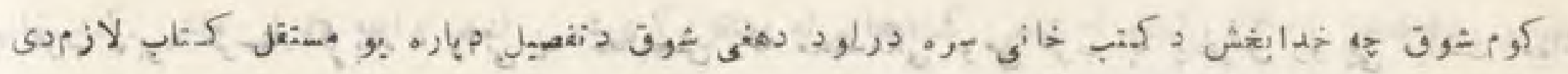

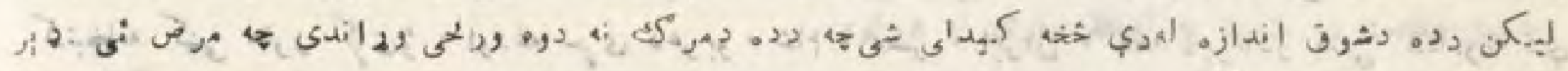

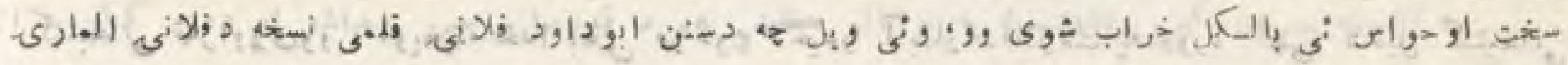

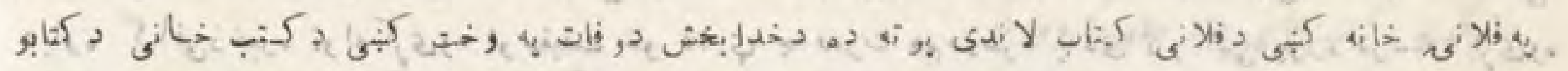

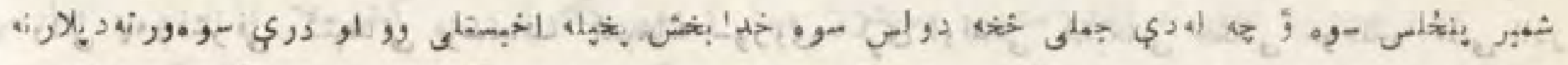

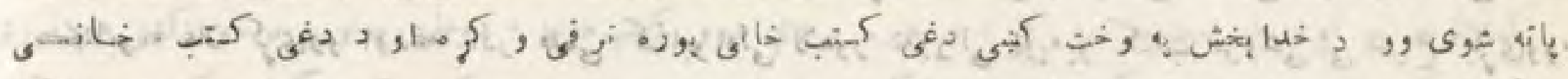

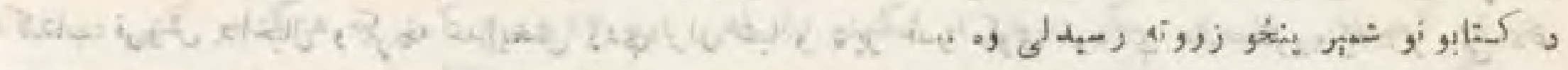

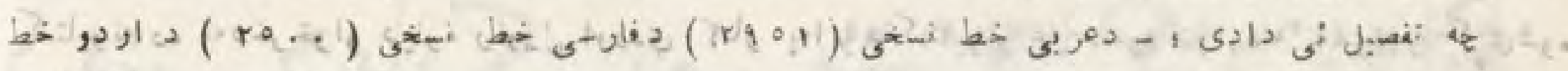

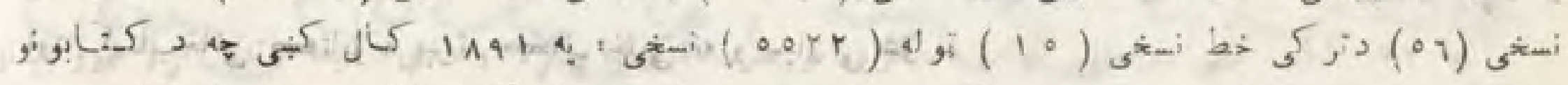

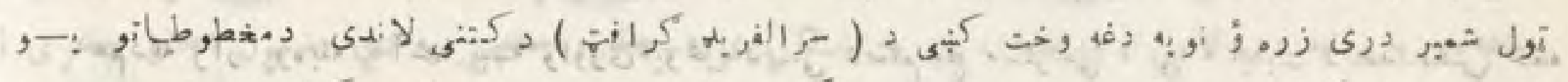

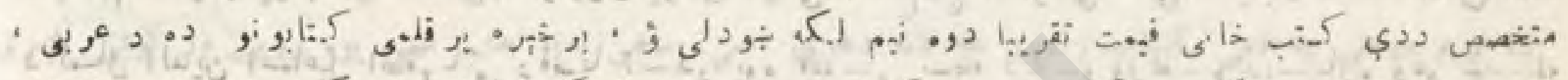

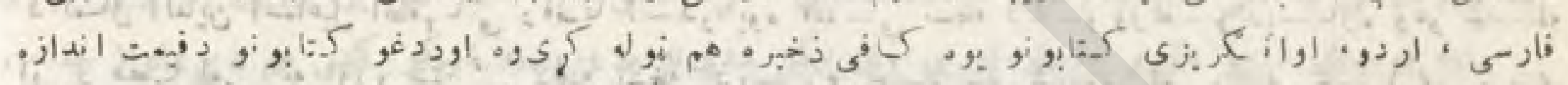

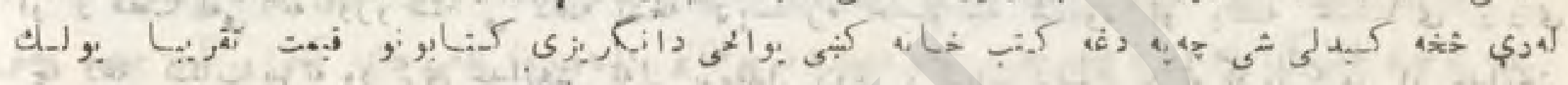

מ.

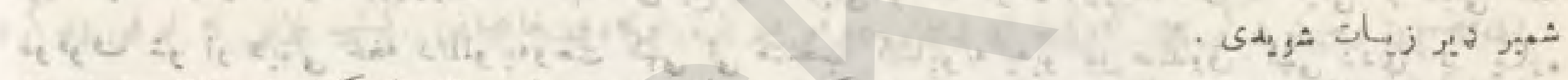

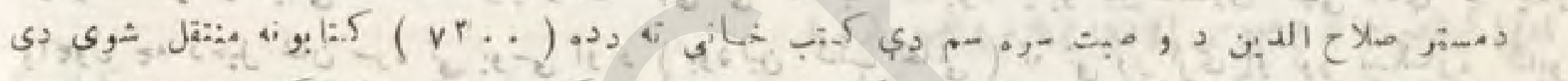

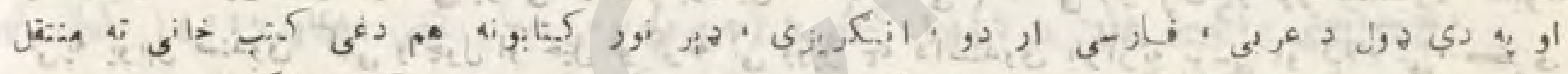

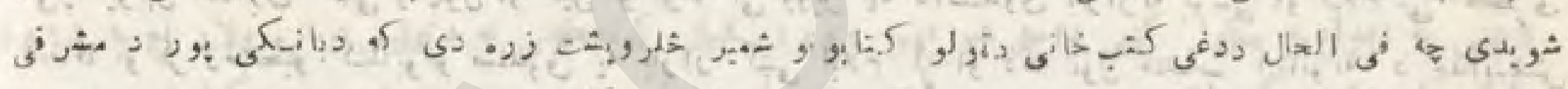
s, 4 a 4 il

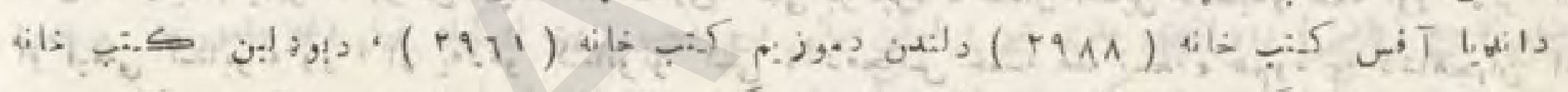

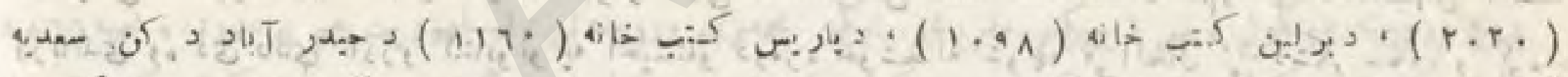
2.

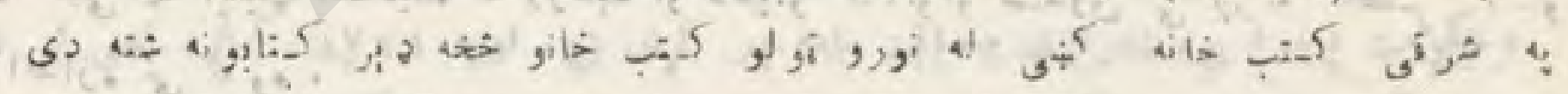

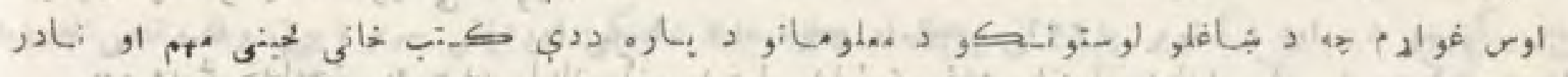

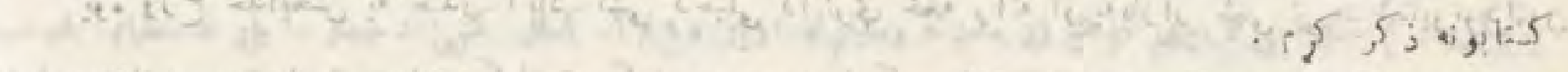

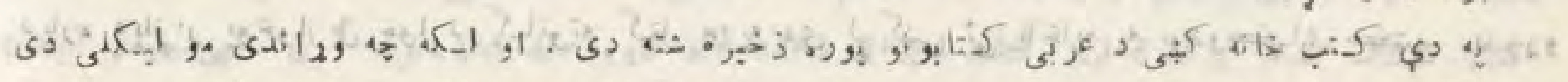

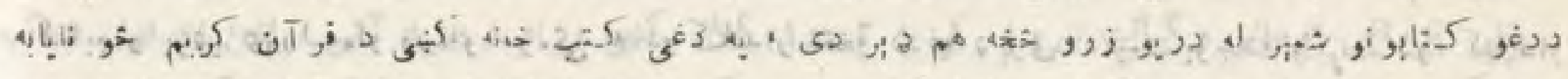

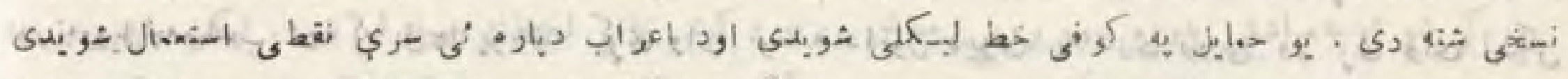

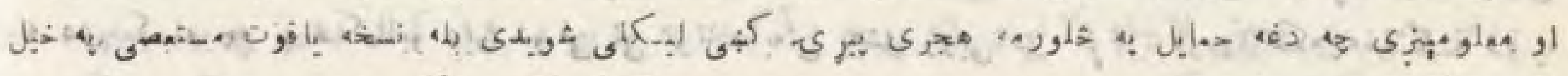

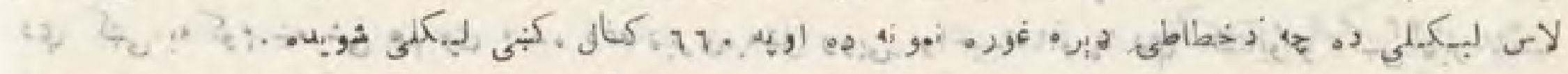

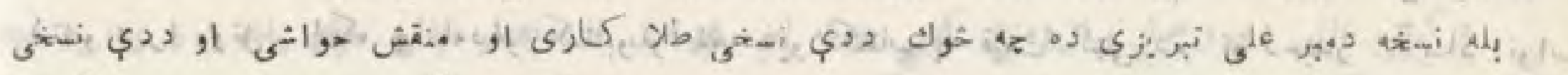

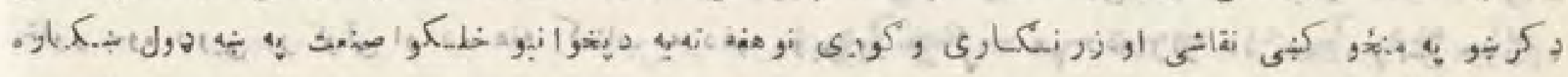

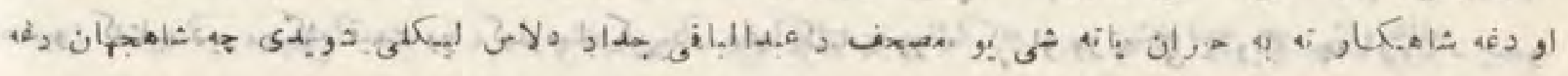

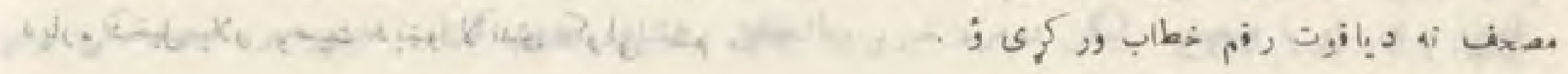




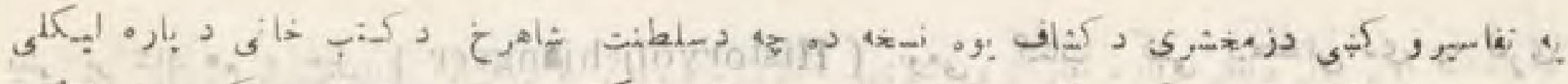

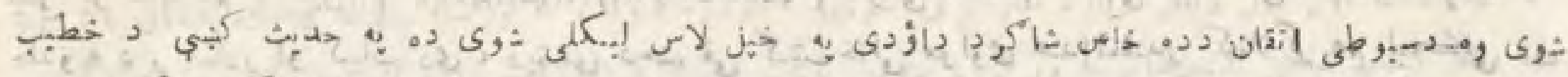

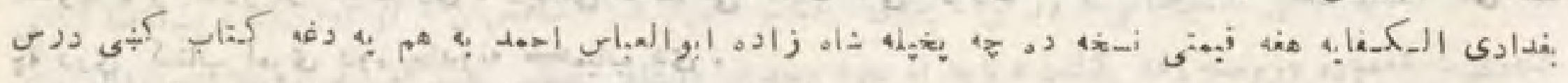

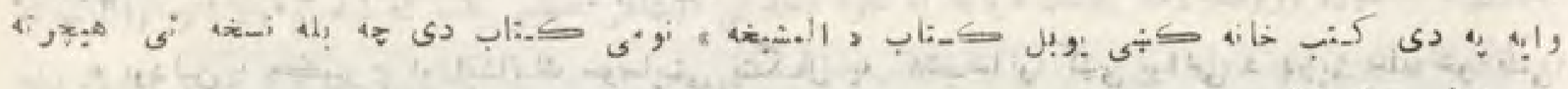

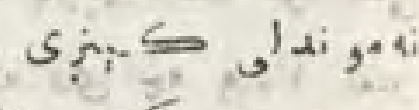

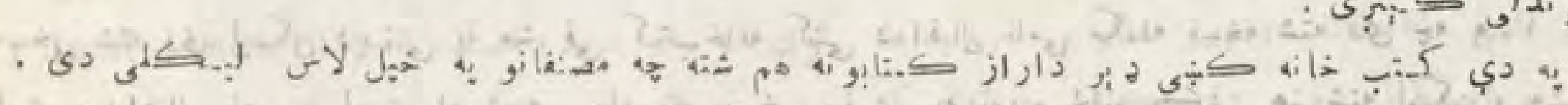

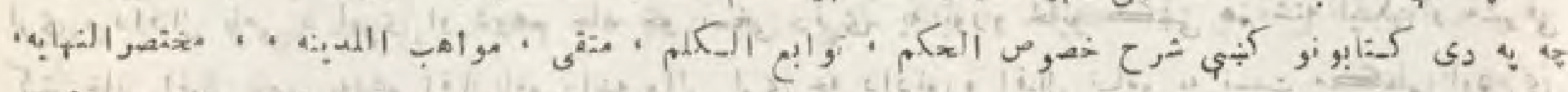

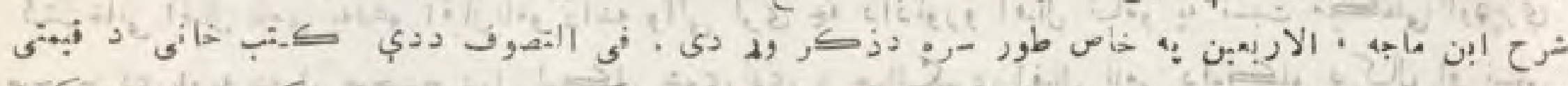

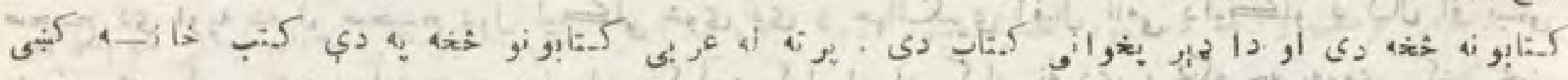

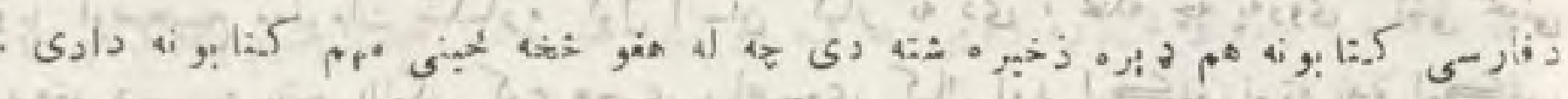

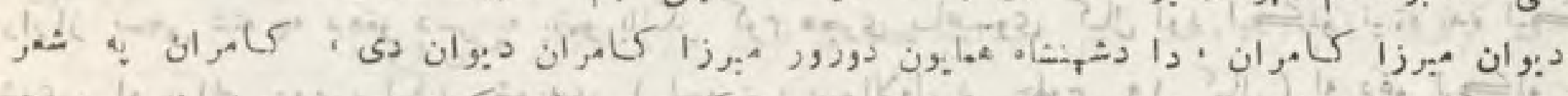

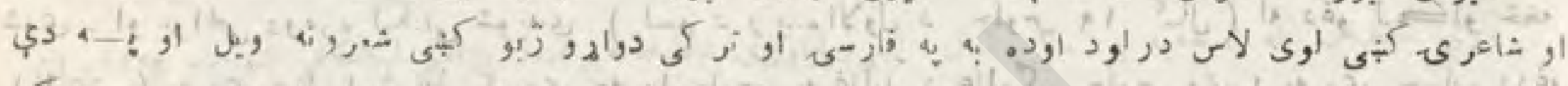

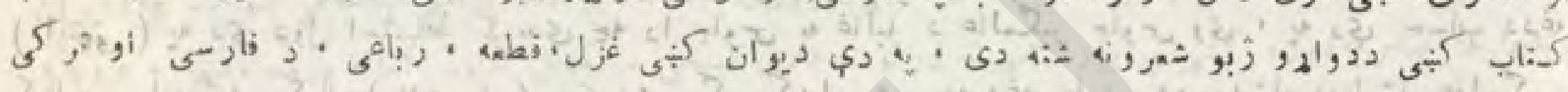

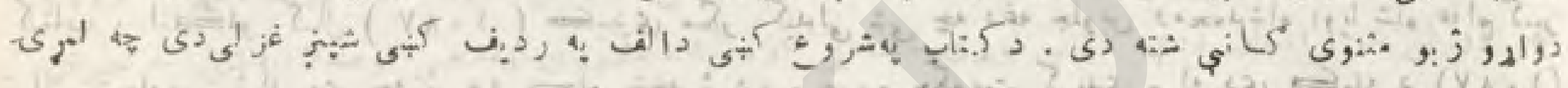

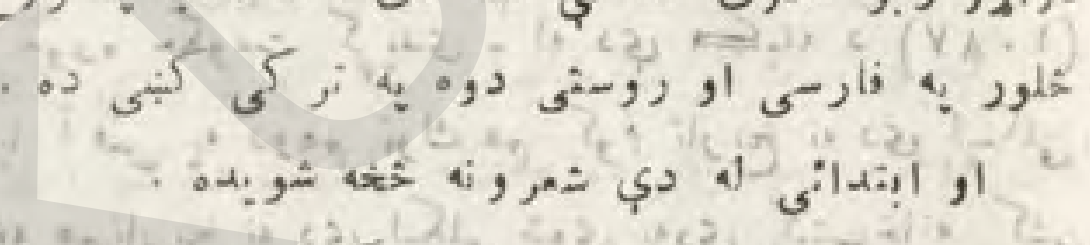

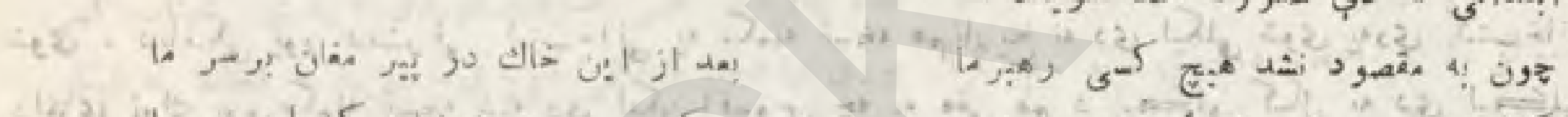

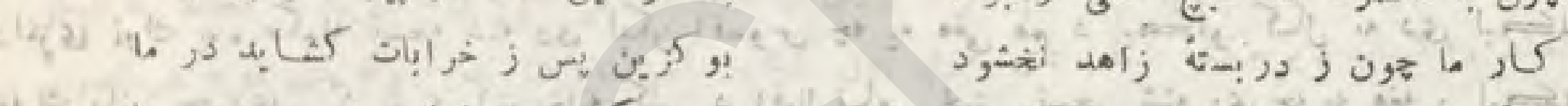

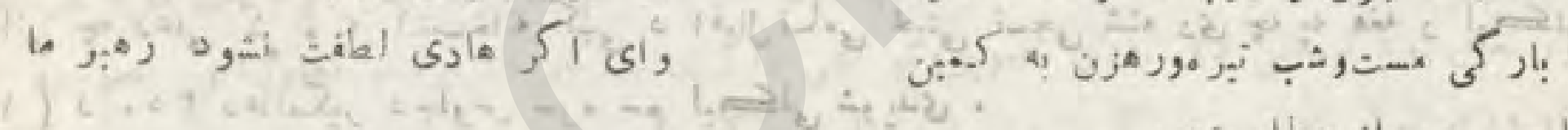

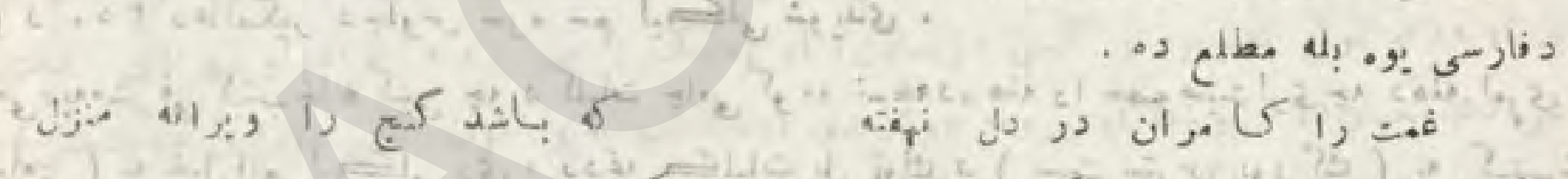

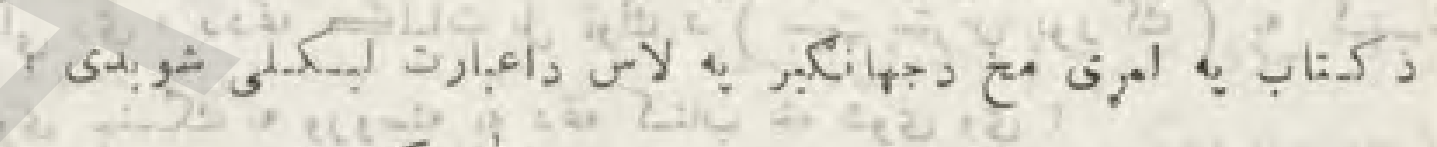

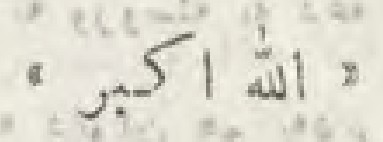

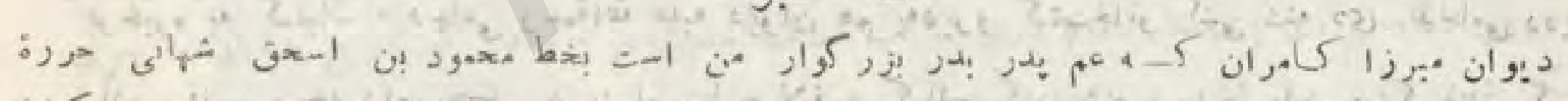
وأبراب دأي

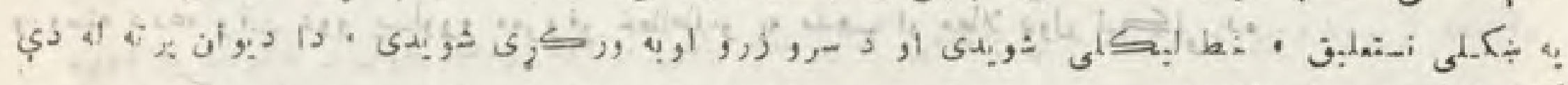

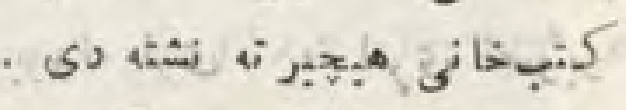

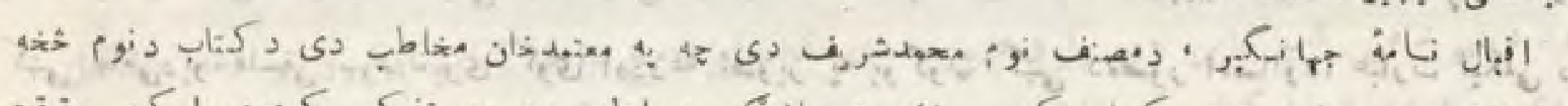

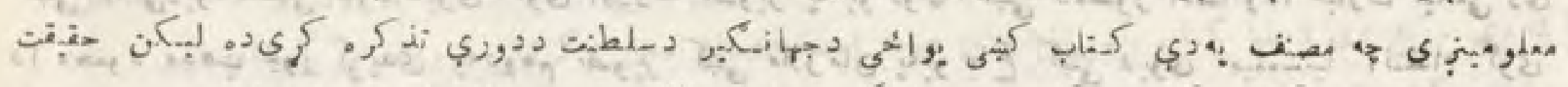

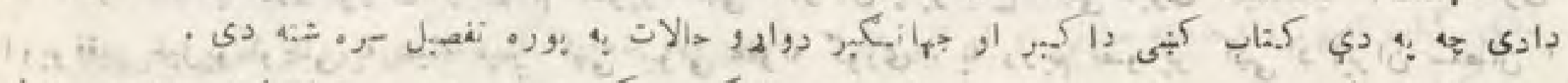

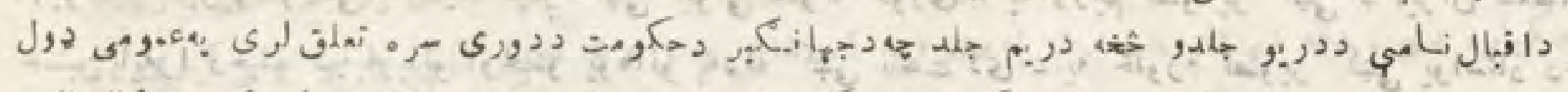

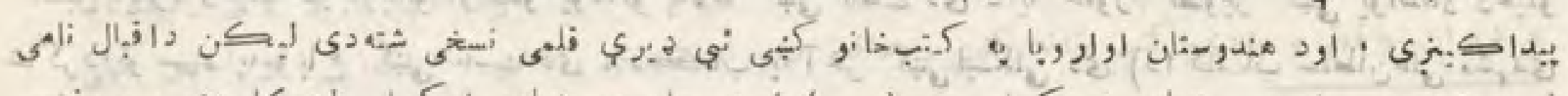

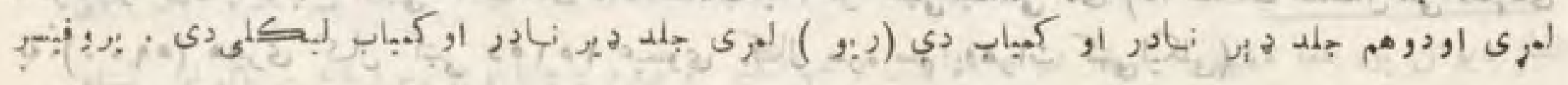




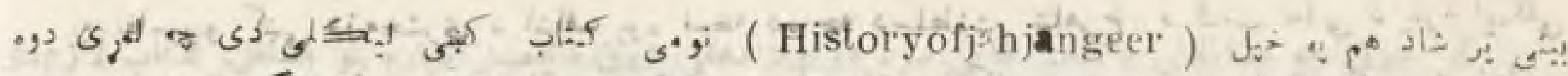

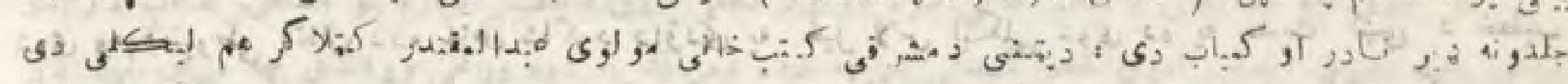

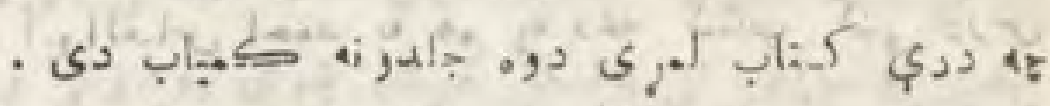

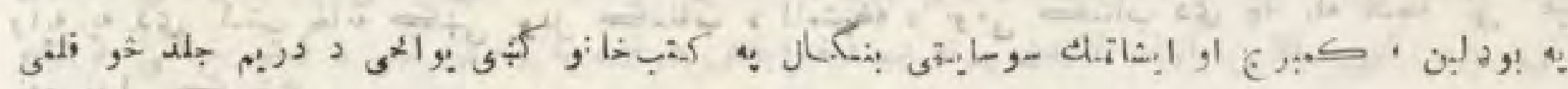

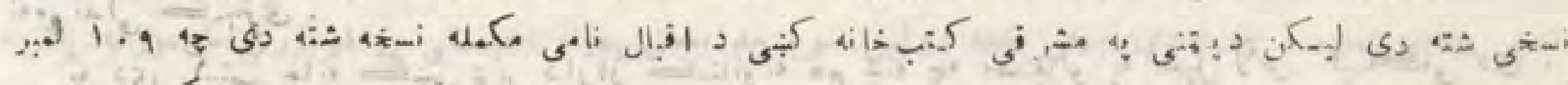

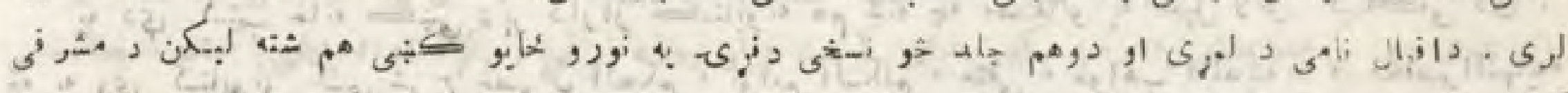

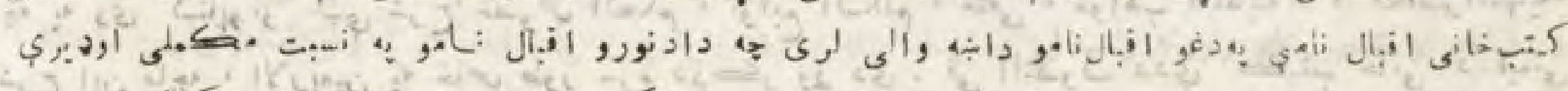

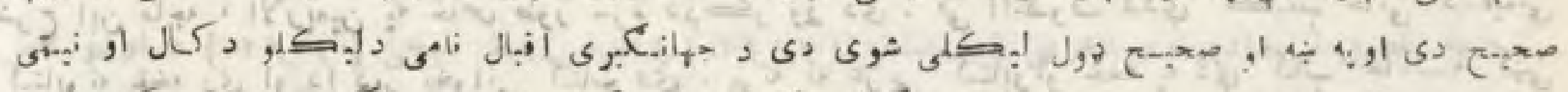

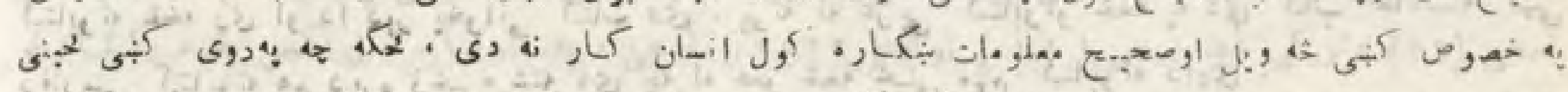

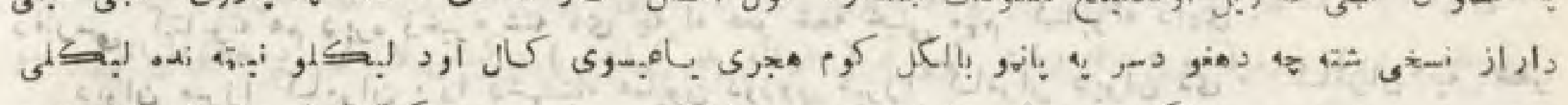

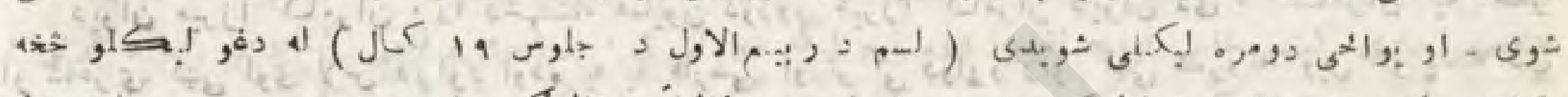

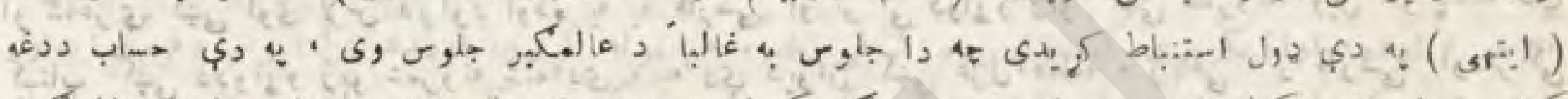

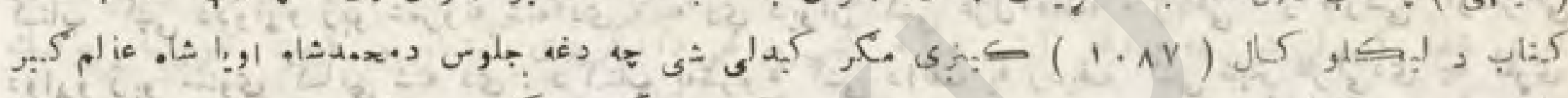

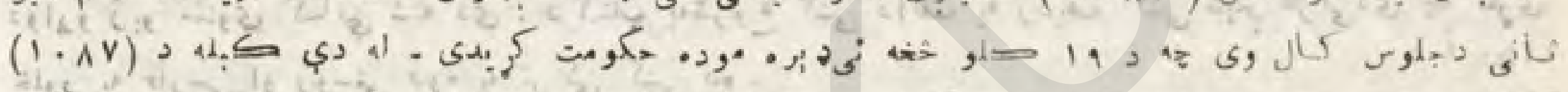

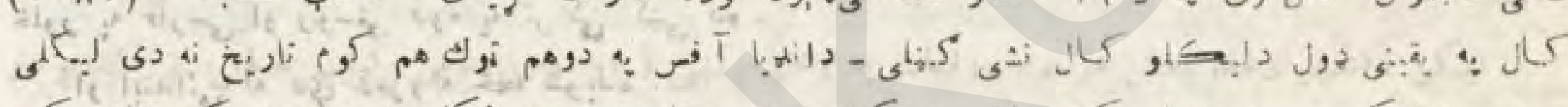

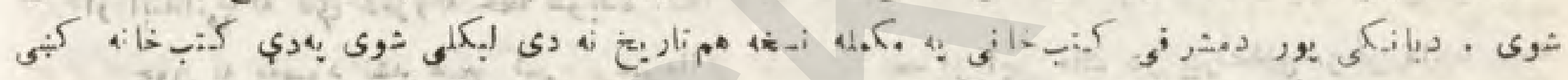

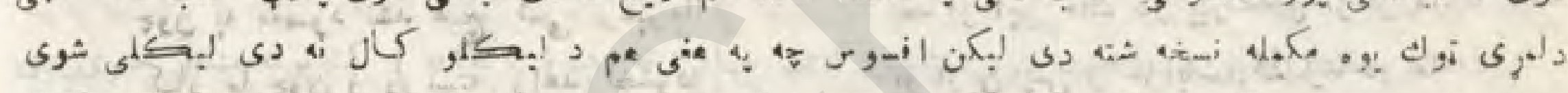

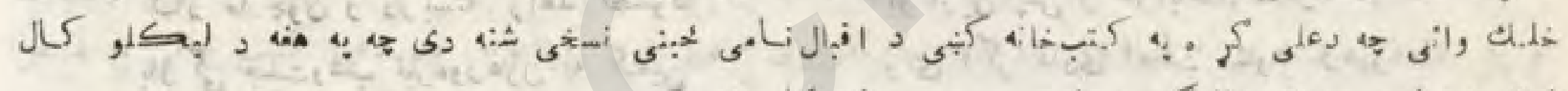
.

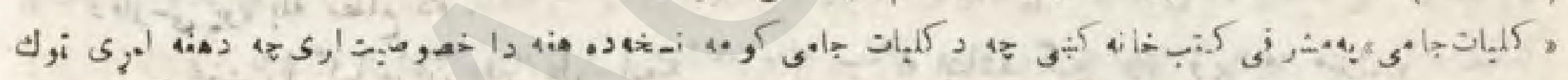

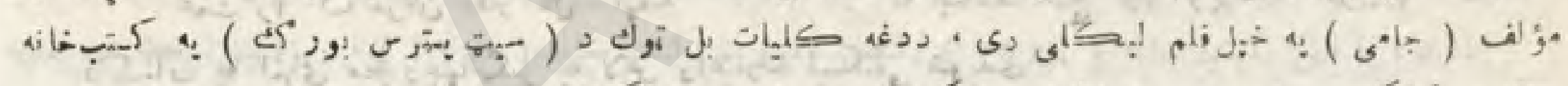

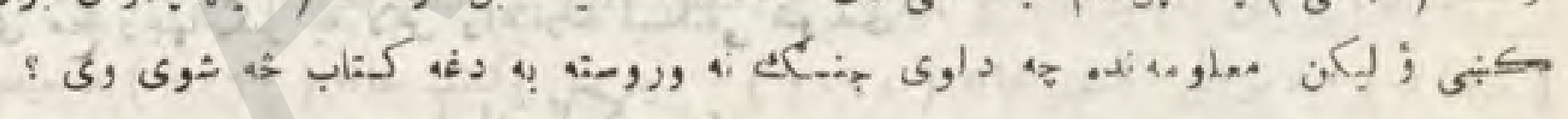

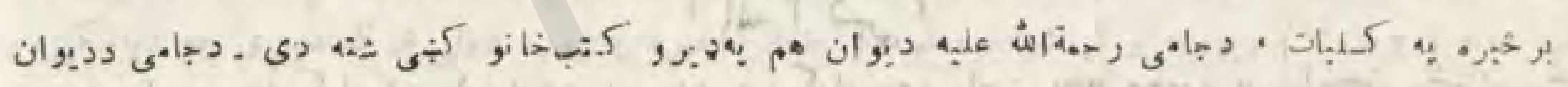

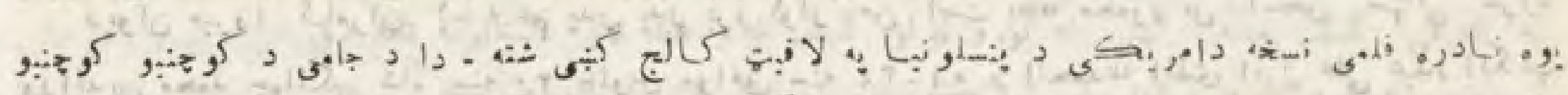

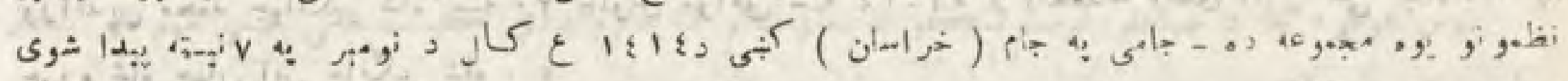

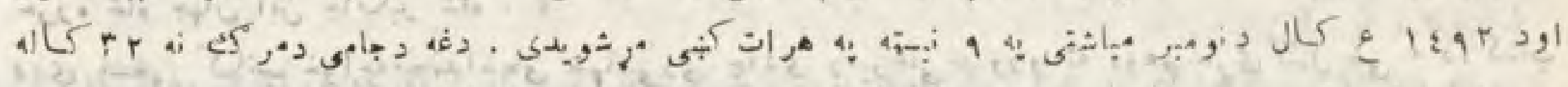

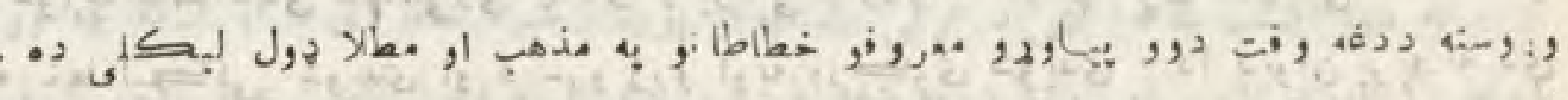

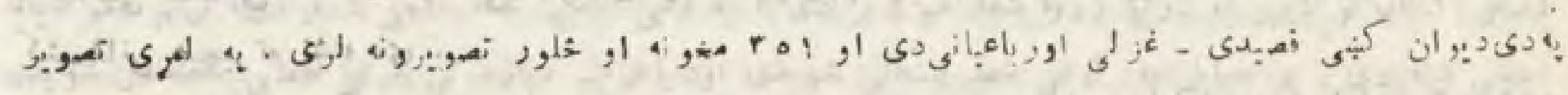

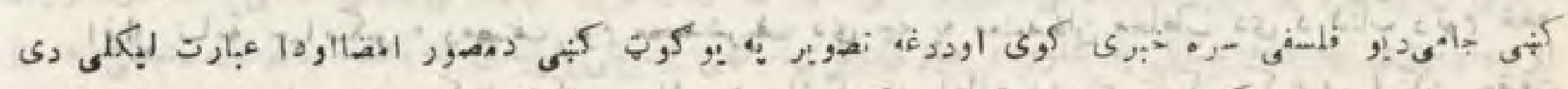

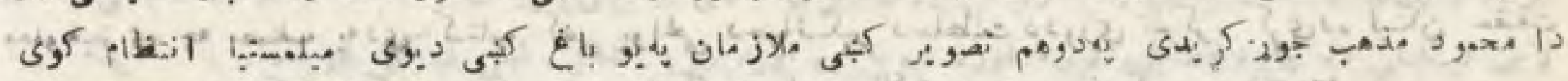

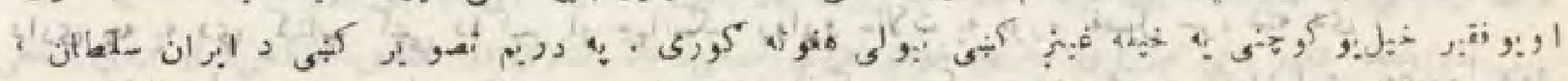
定

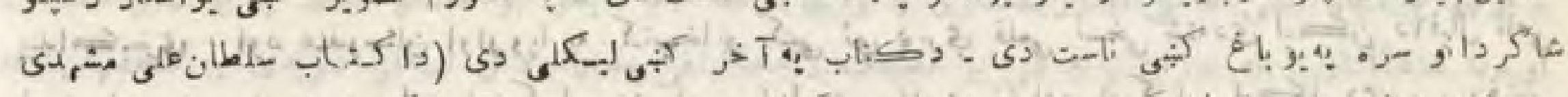
. 


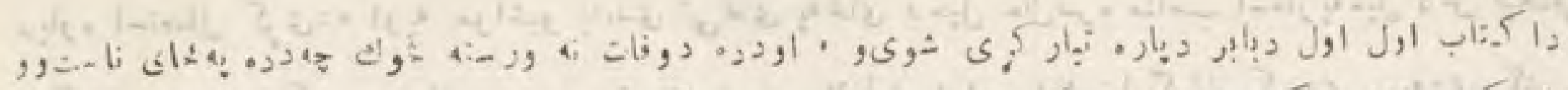

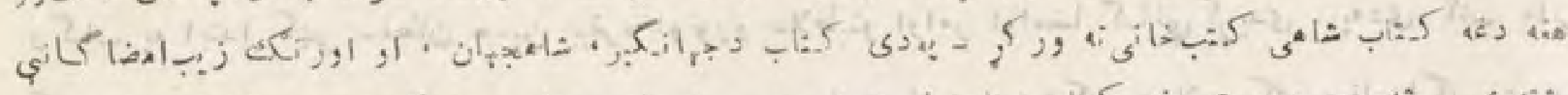

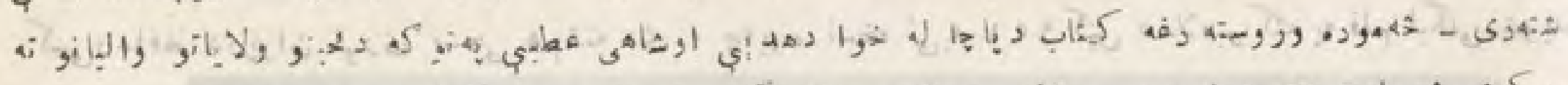

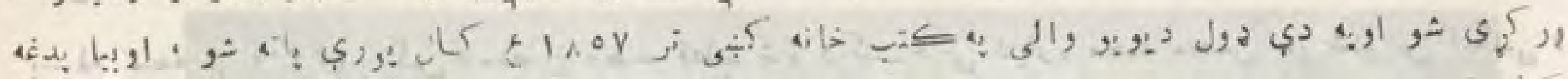

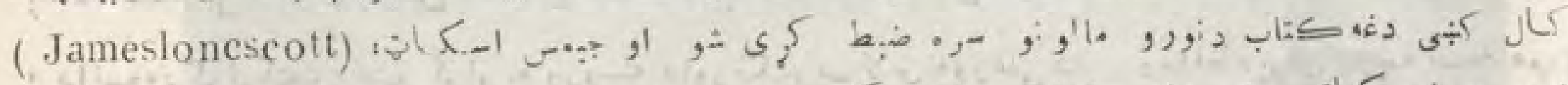

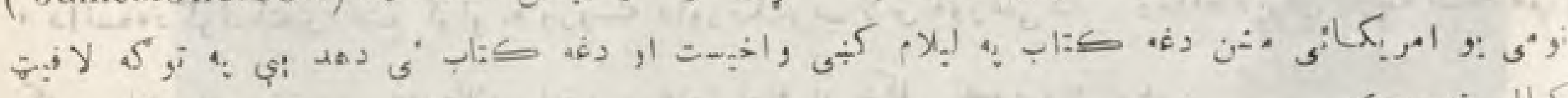

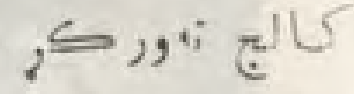

2

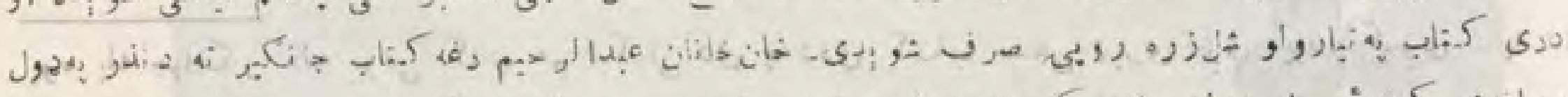
. 2

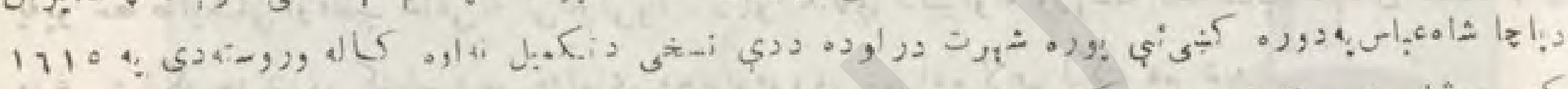

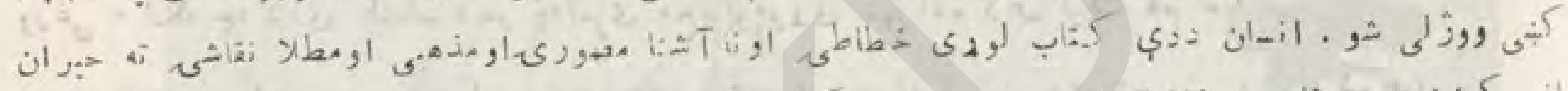

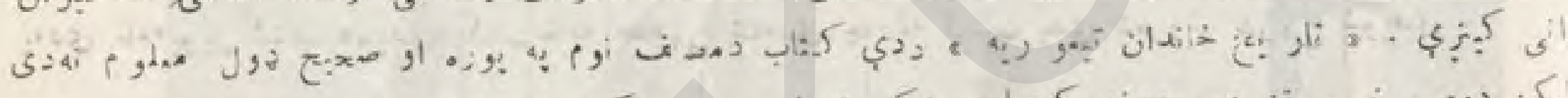

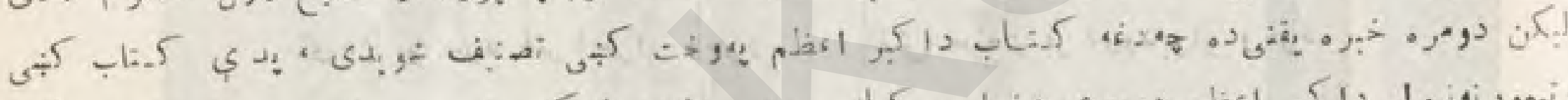

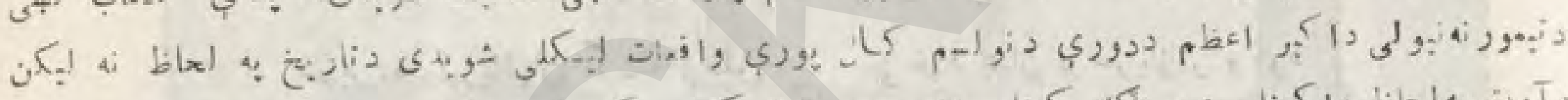

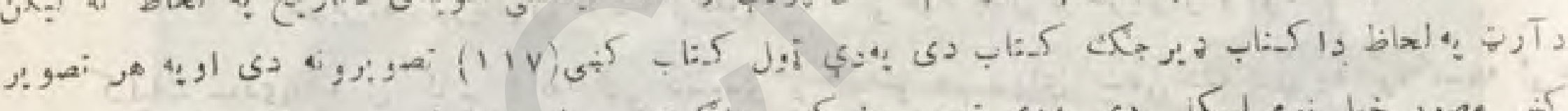

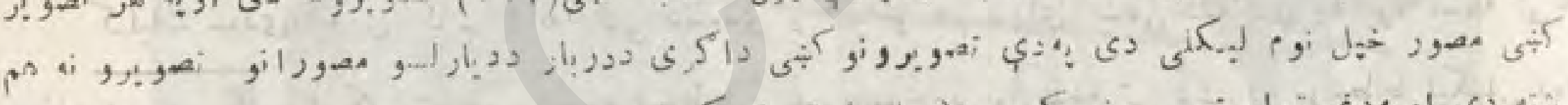

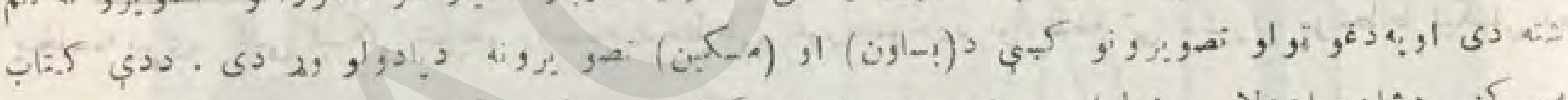

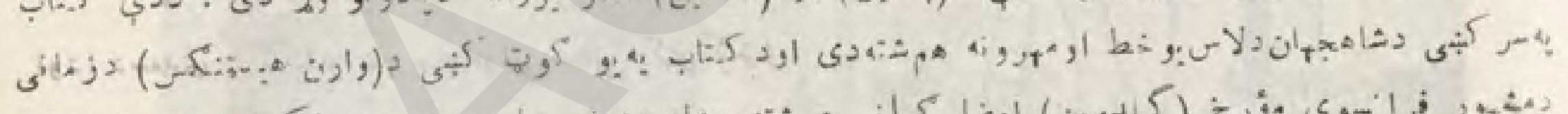

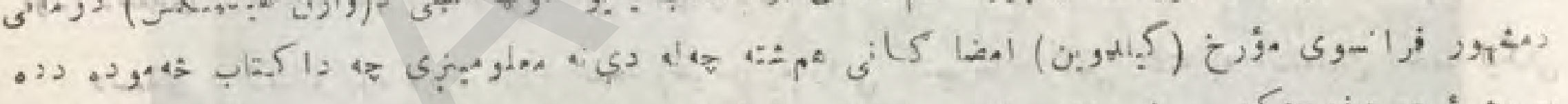

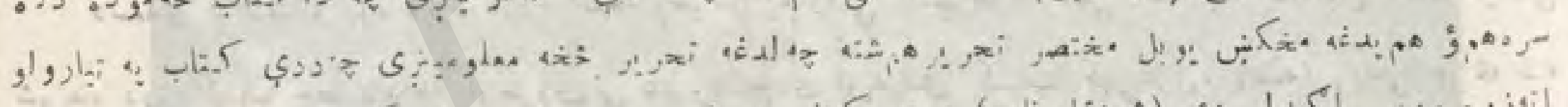

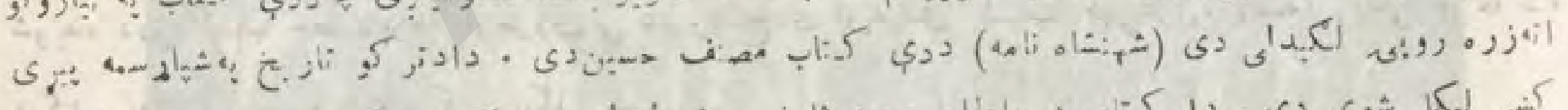

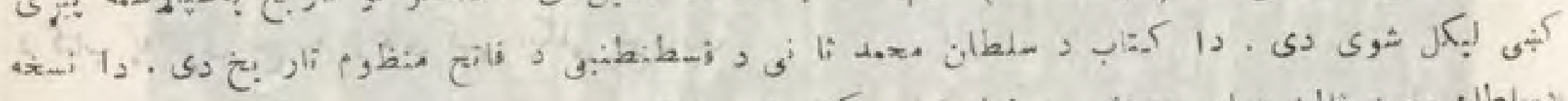

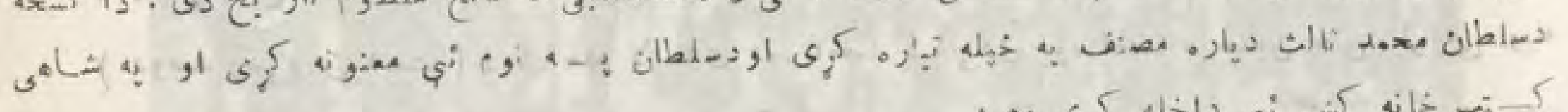

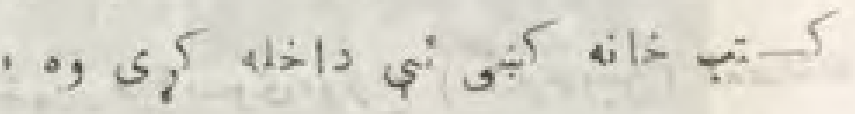
مورد o

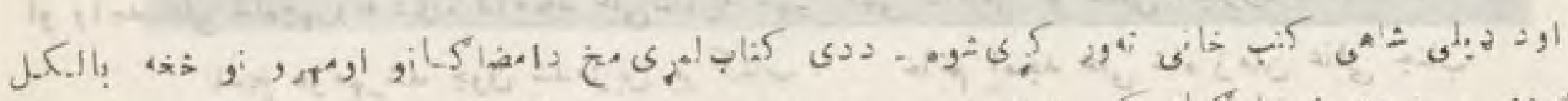

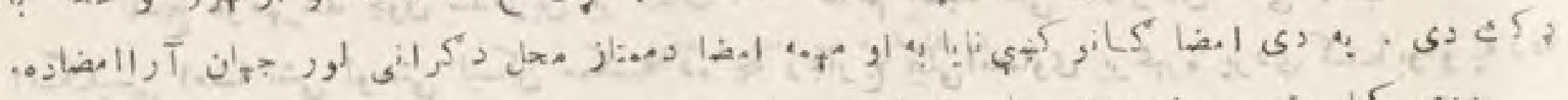

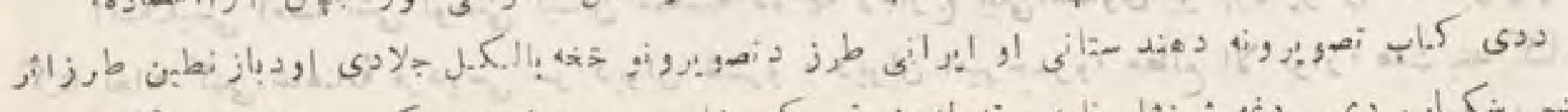
ل s

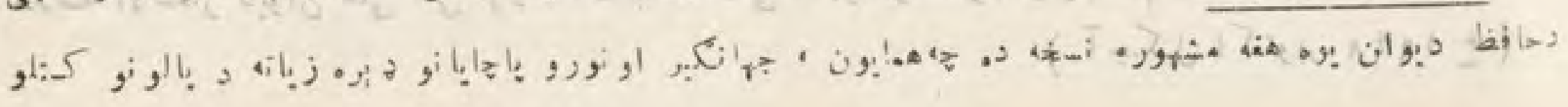




\section{$(r+)$}

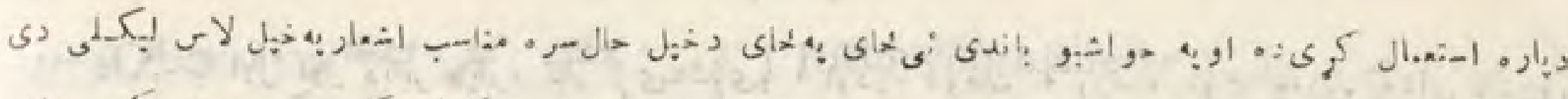
,

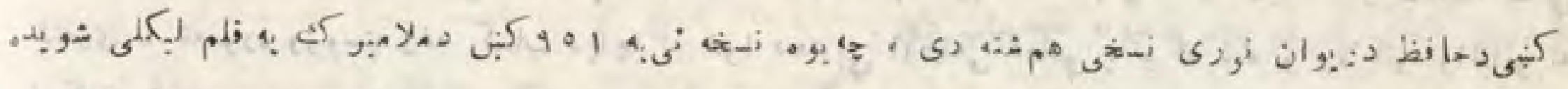

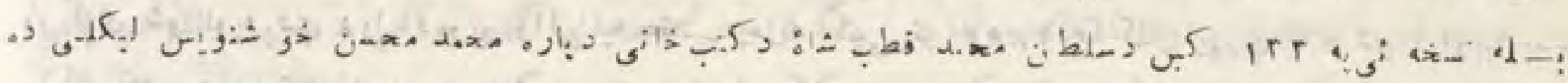

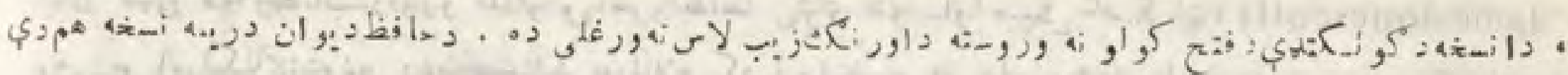

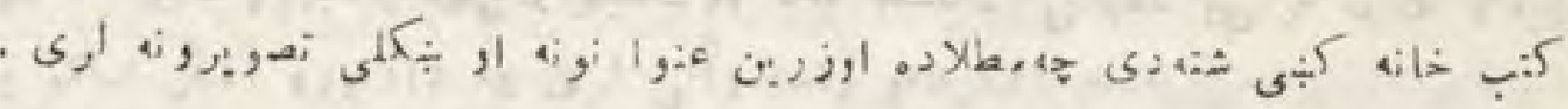

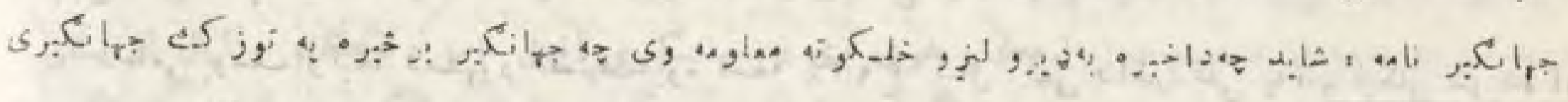

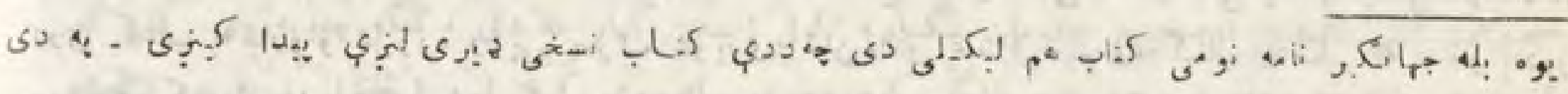

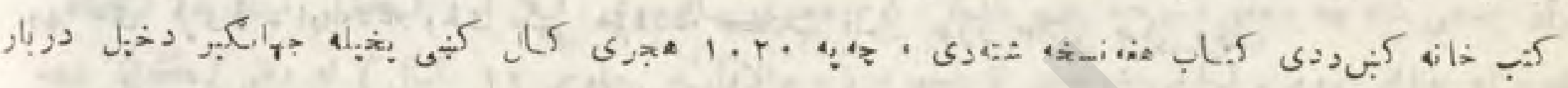

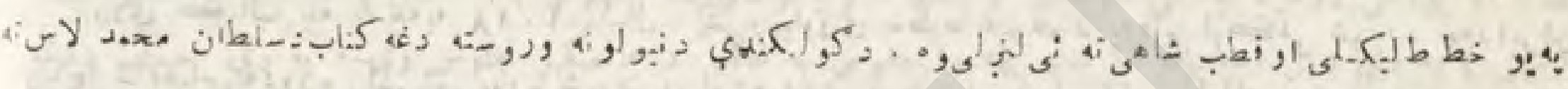

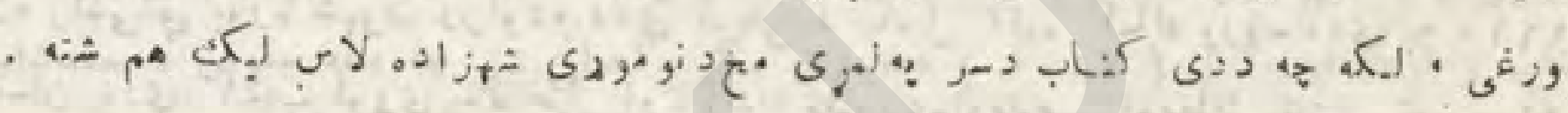

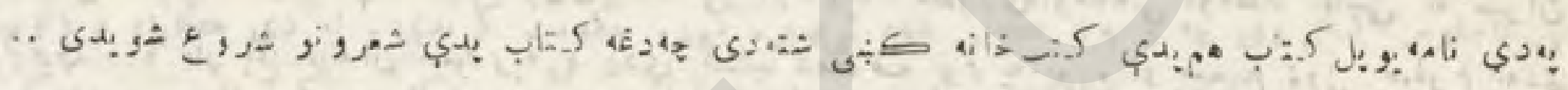

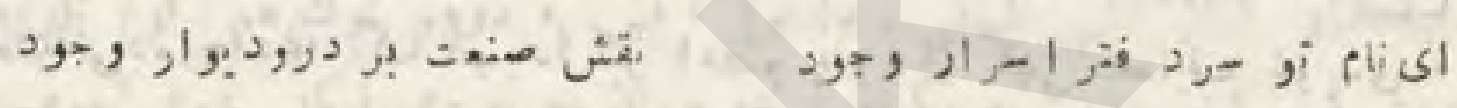

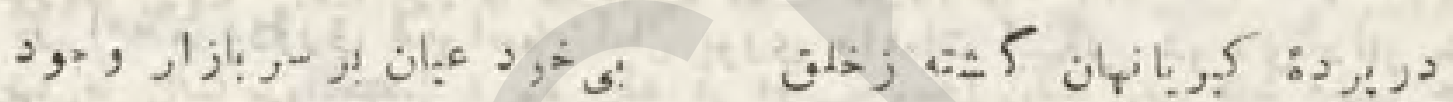

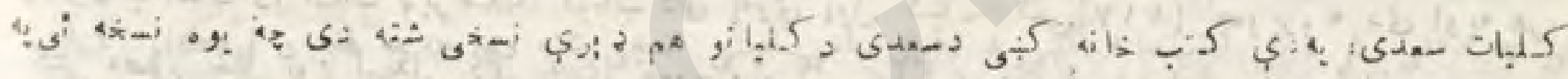

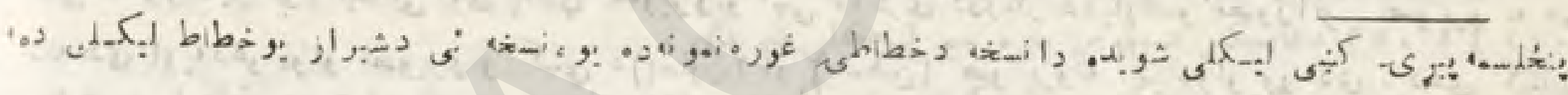
.

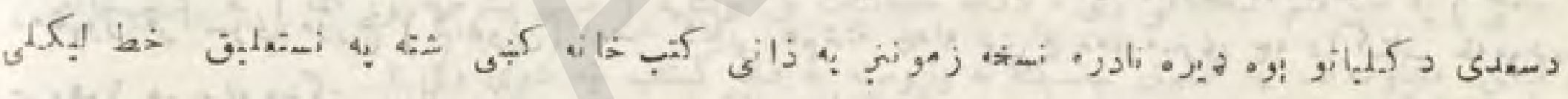

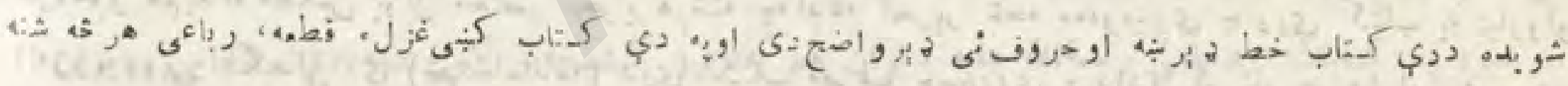

$$
\text { : : : : : : : }
$$

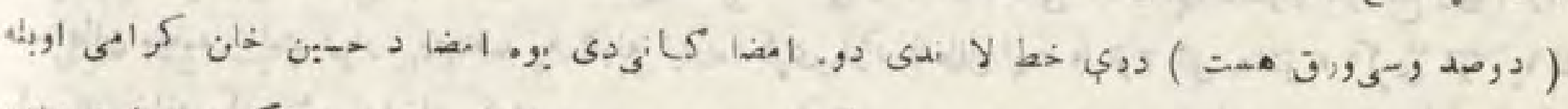

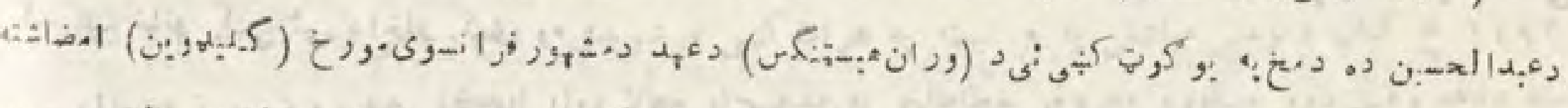

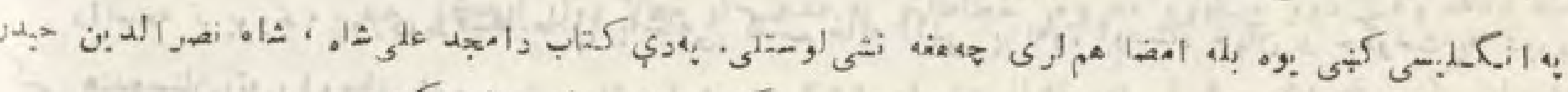

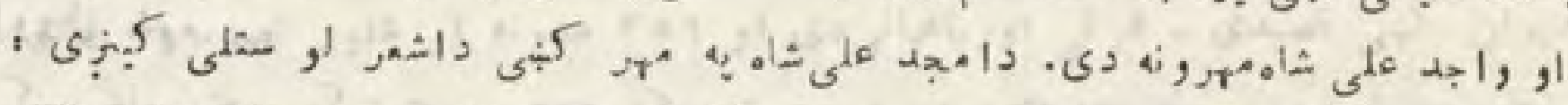

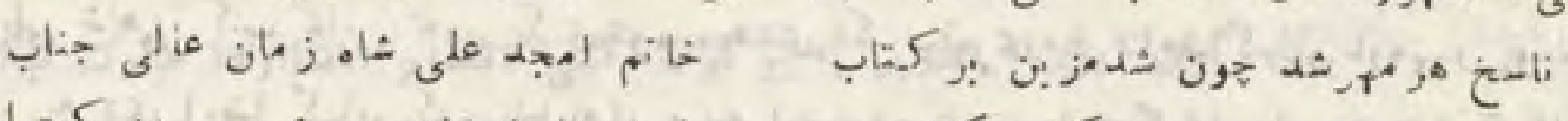

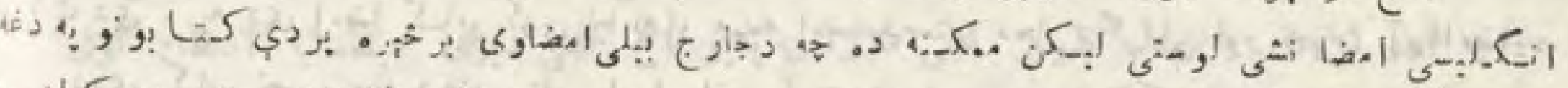

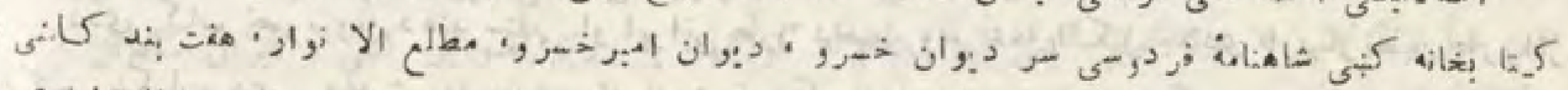

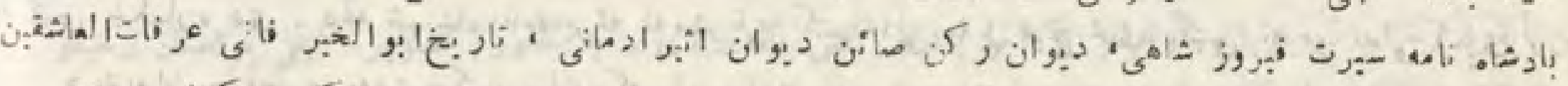

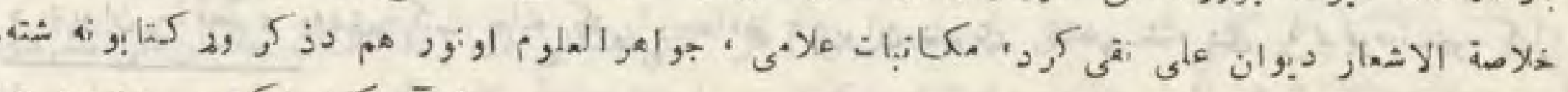

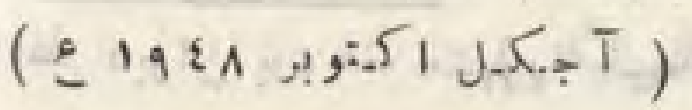




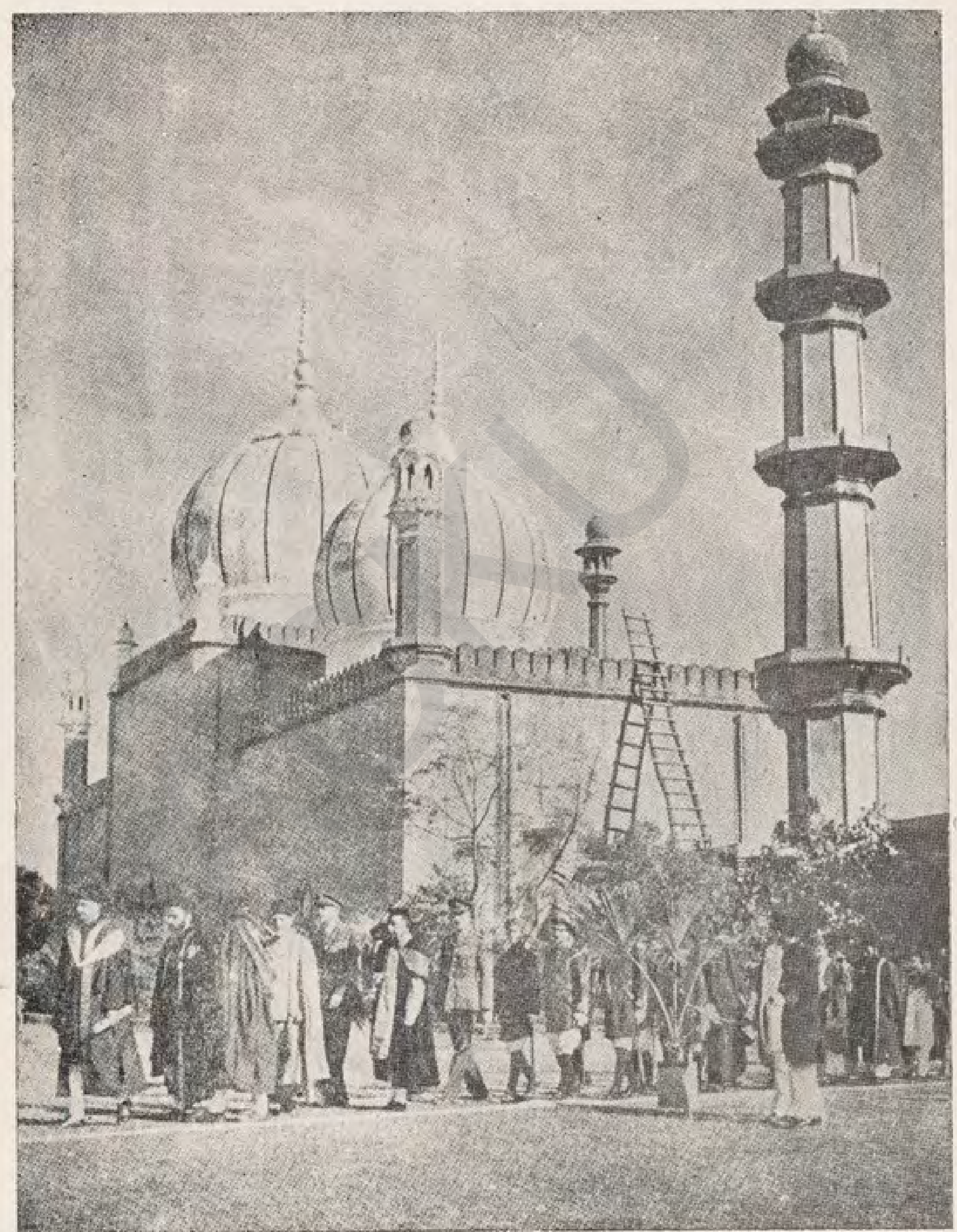

دملكمر• بو نبو رستى 


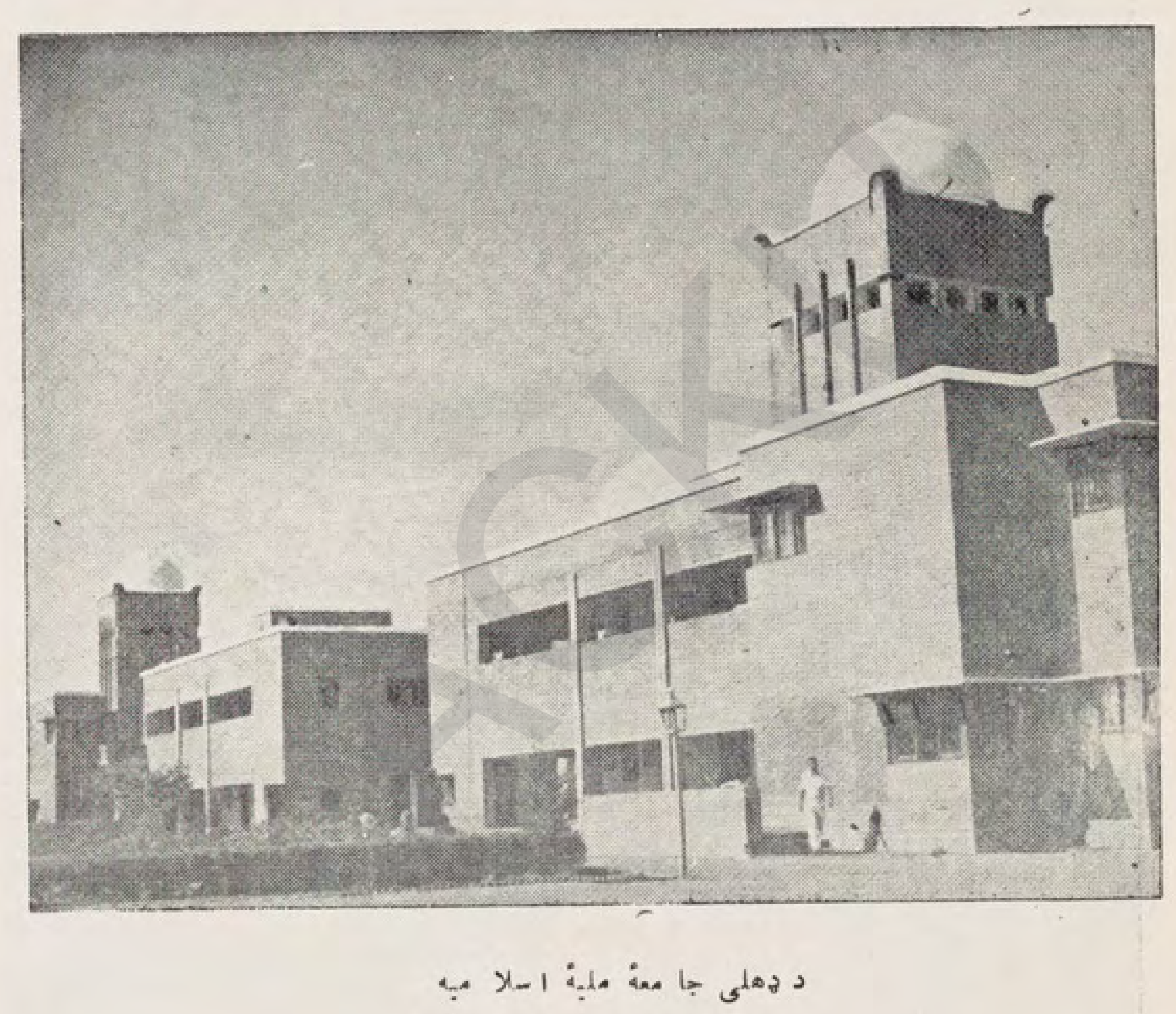




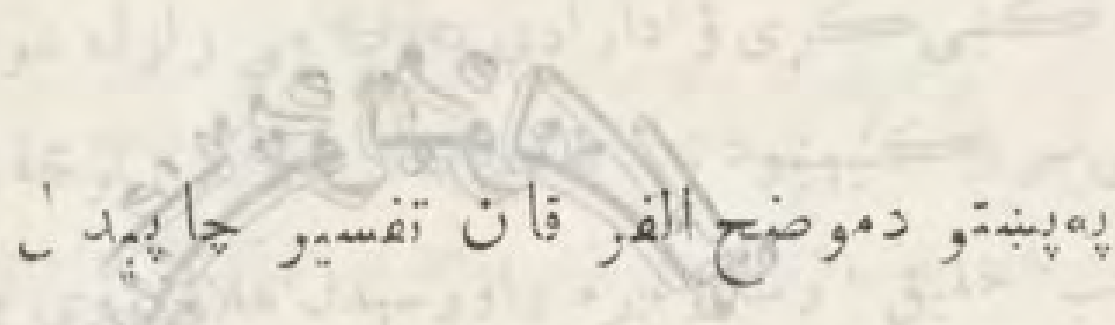

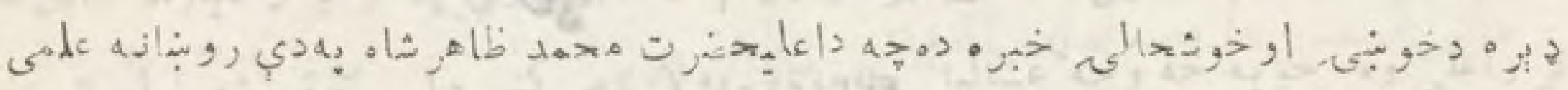

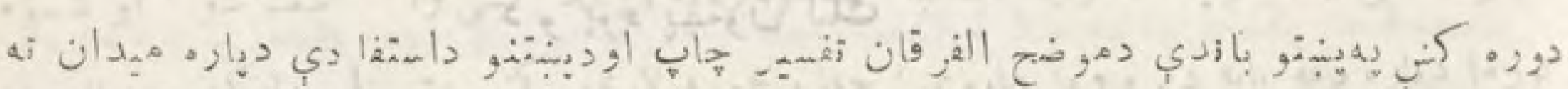

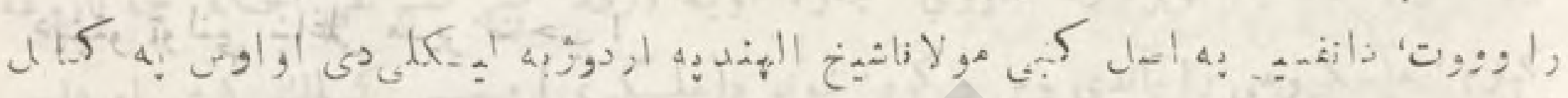

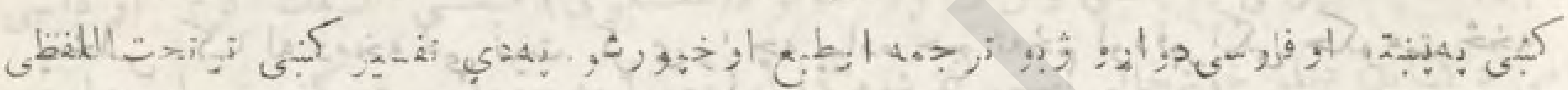

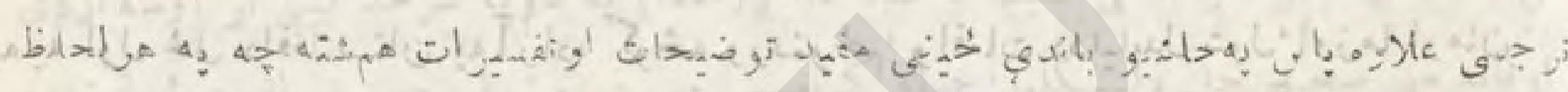
sth

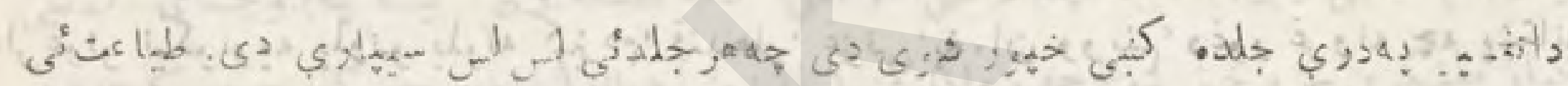
जि

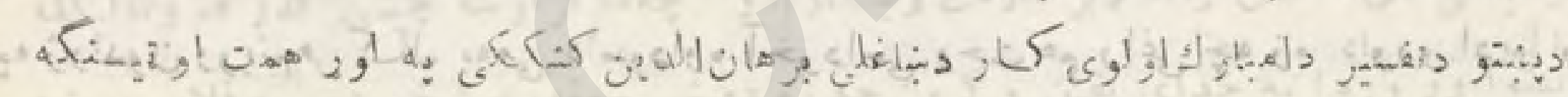

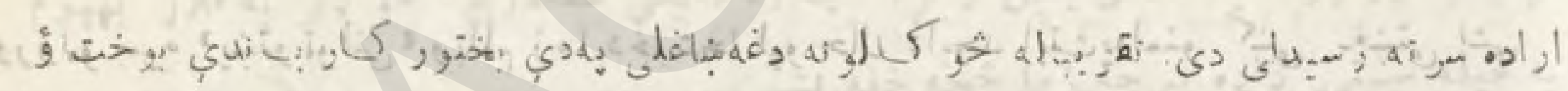

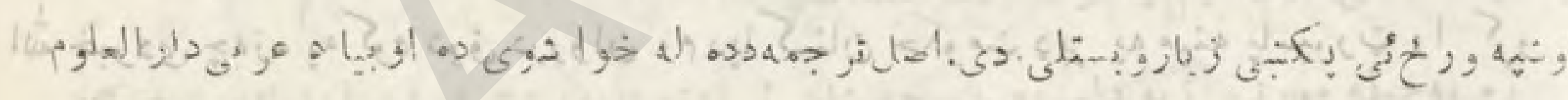

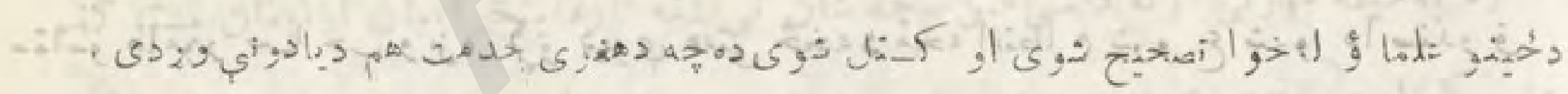

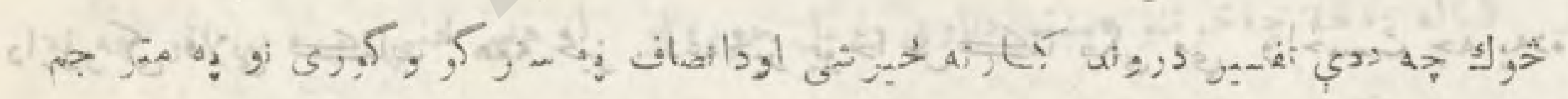

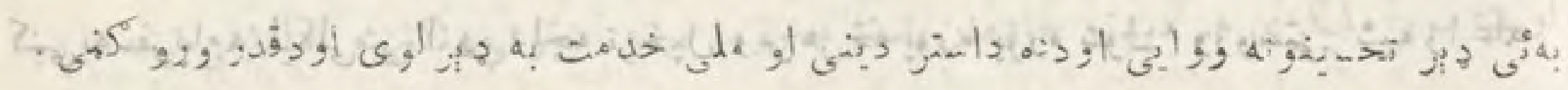

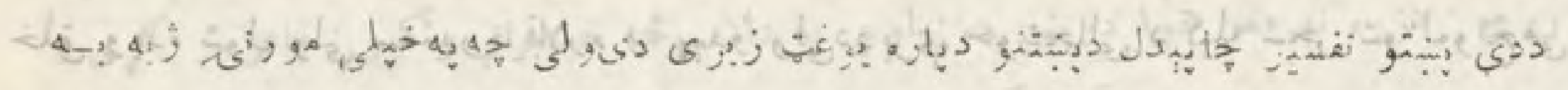

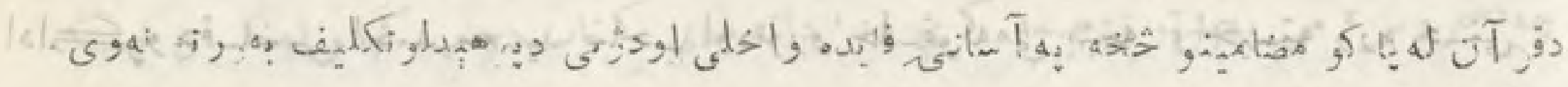

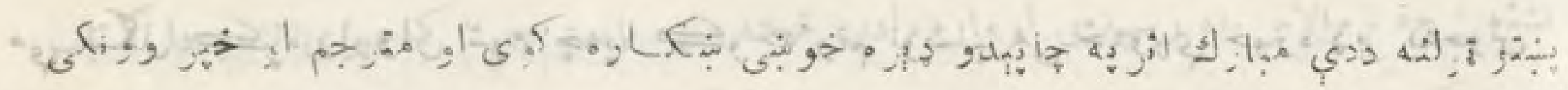

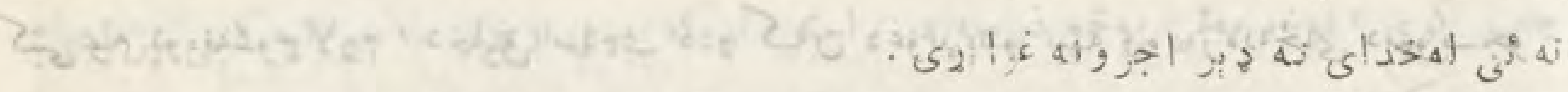

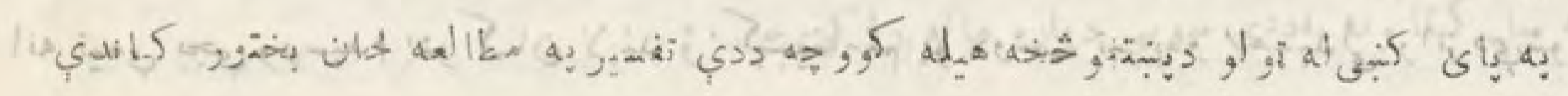

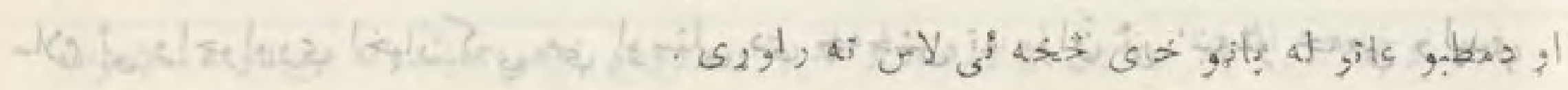

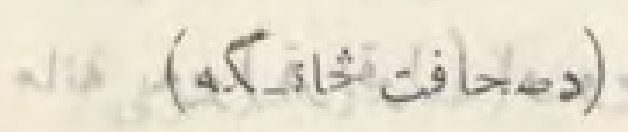




\section{of \\ Sإنو}

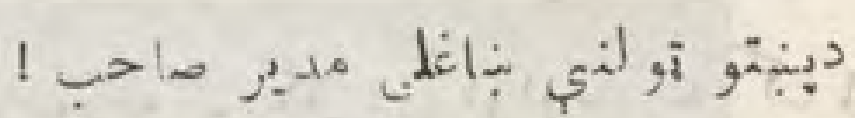

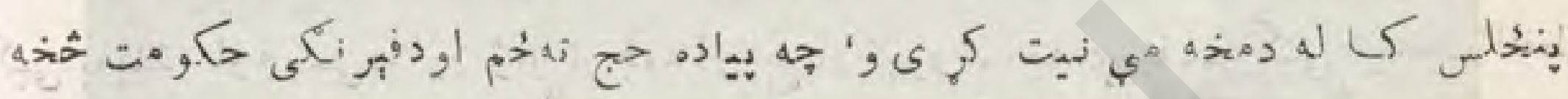

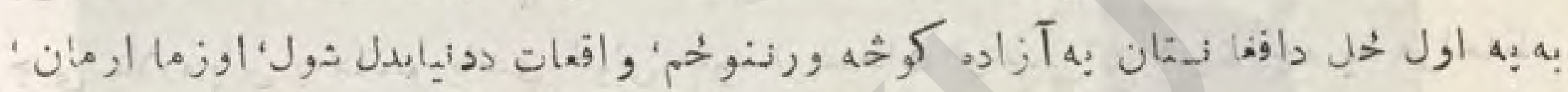

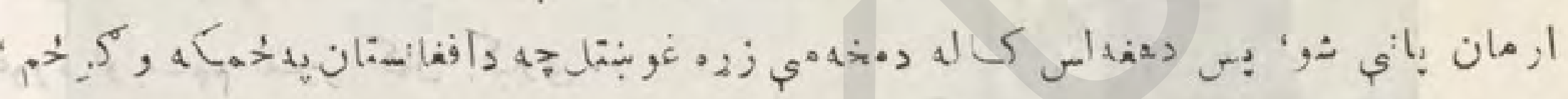

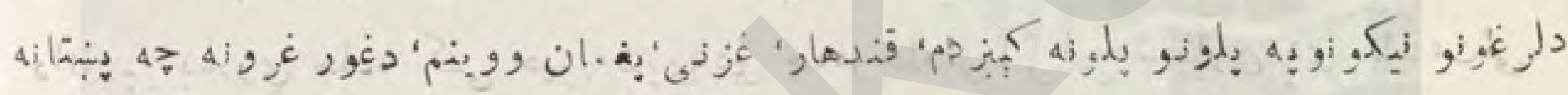

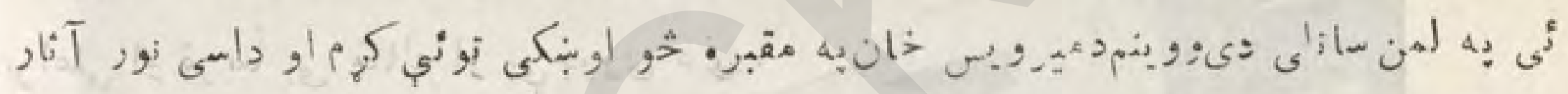

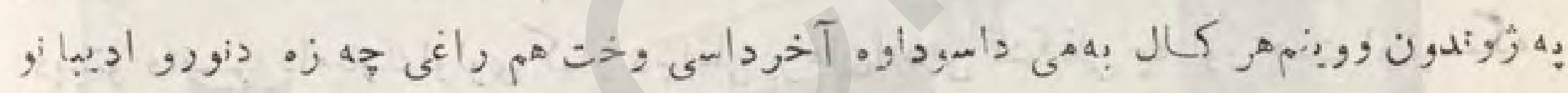

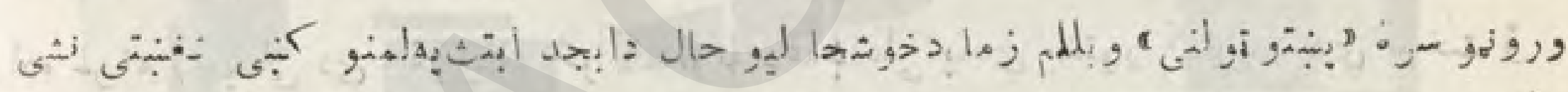

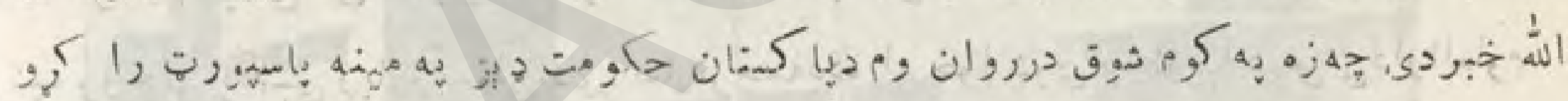

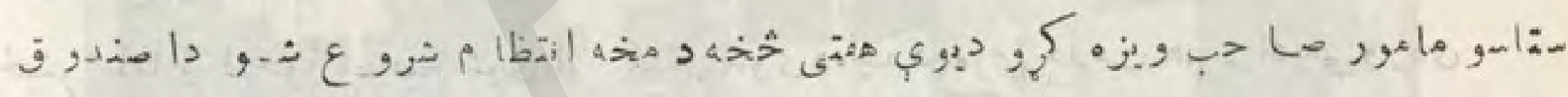

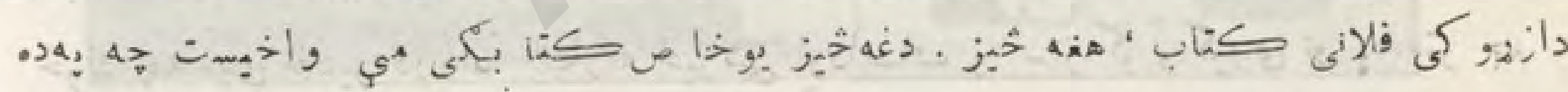

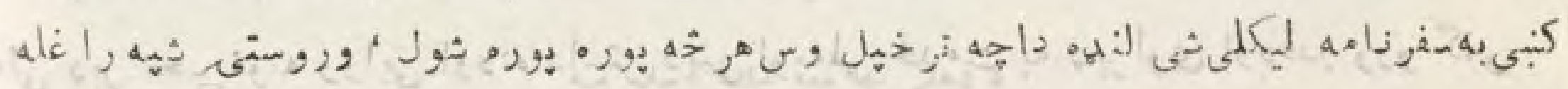

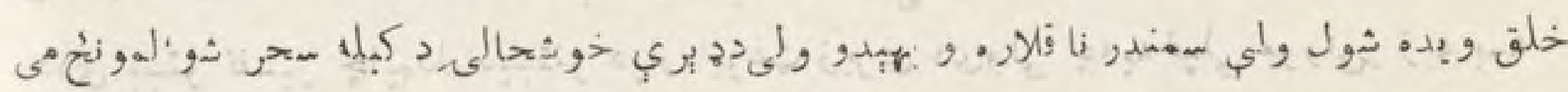

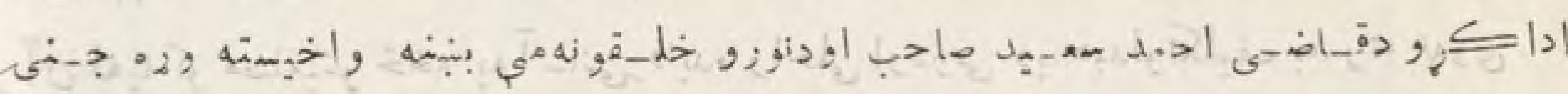

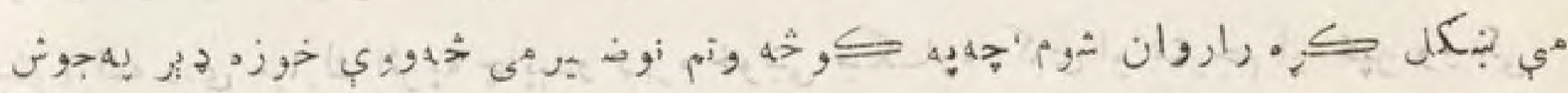

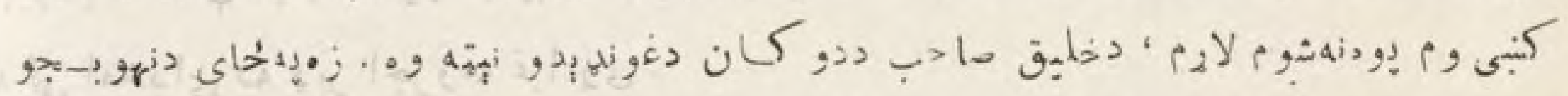

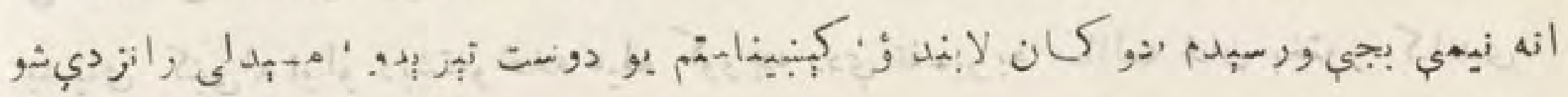

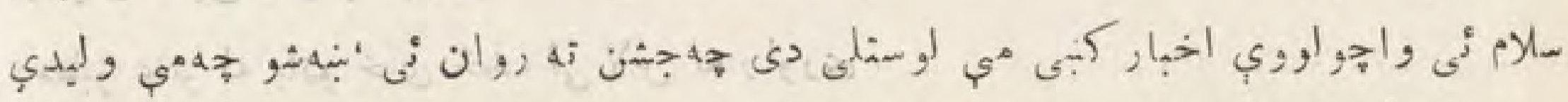

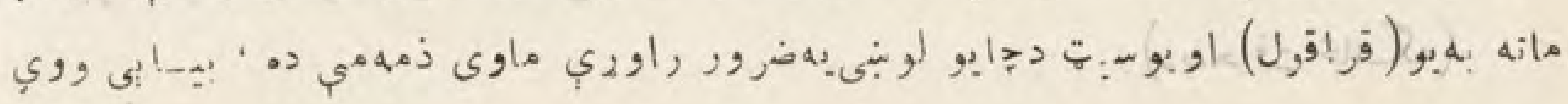




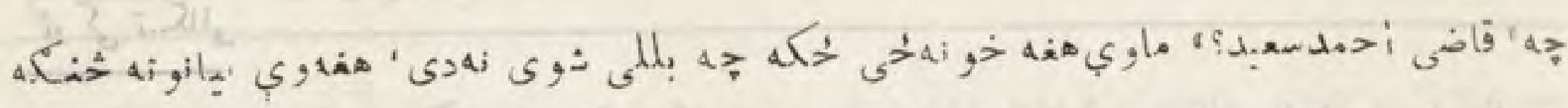

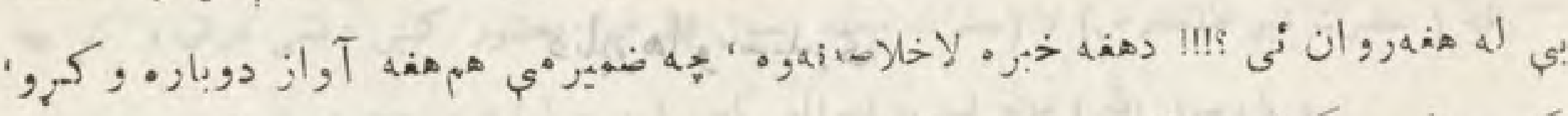

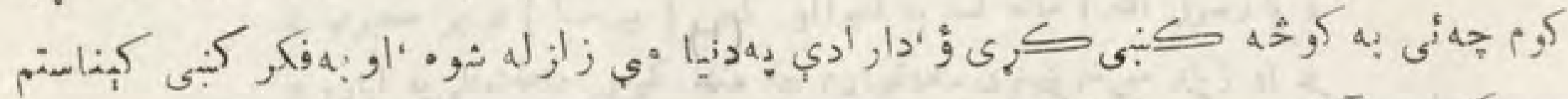

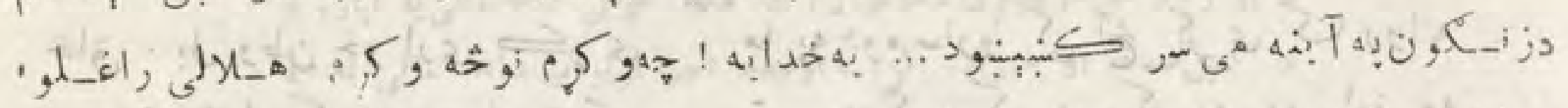

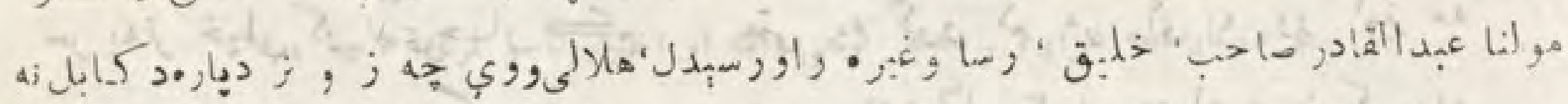
•, مأر

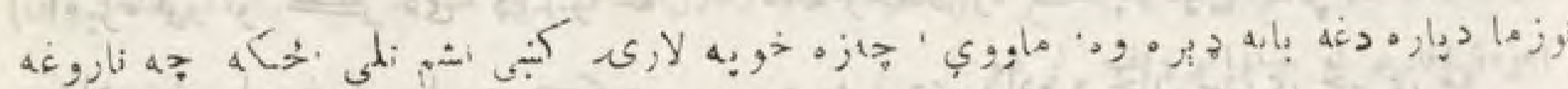

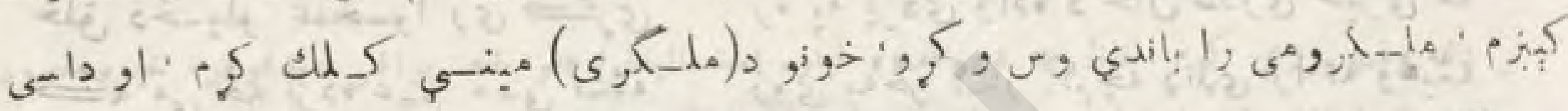

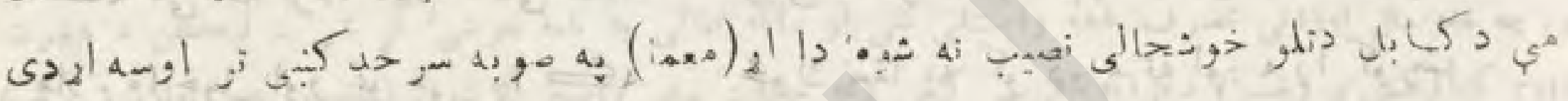

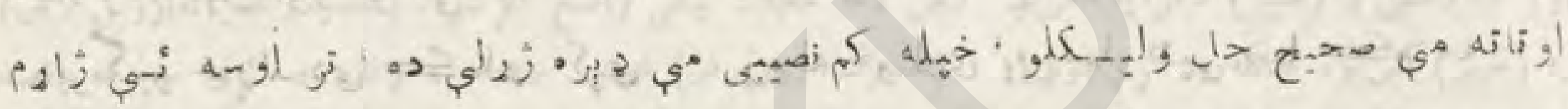

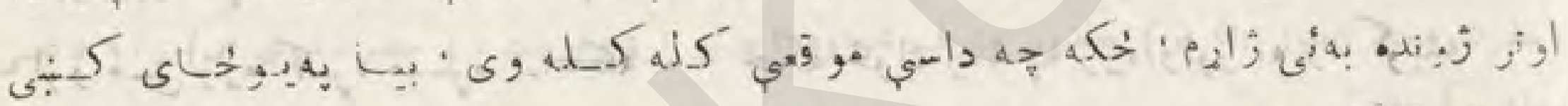

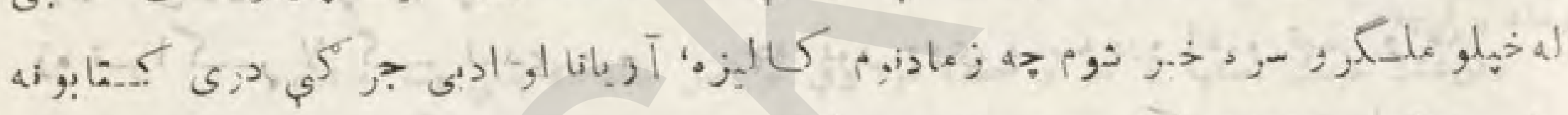

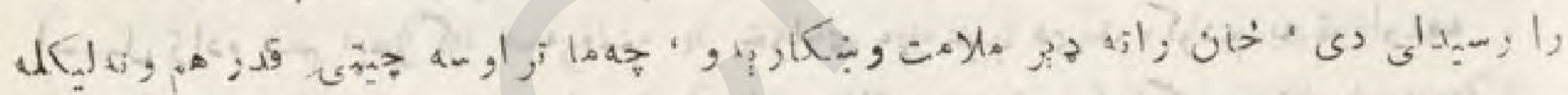

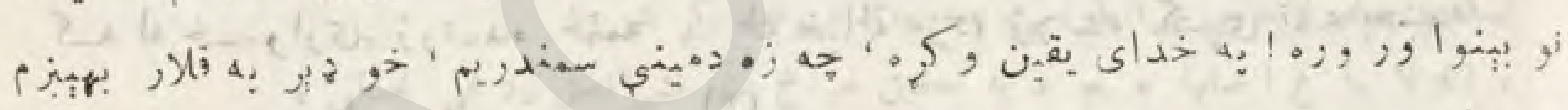
li

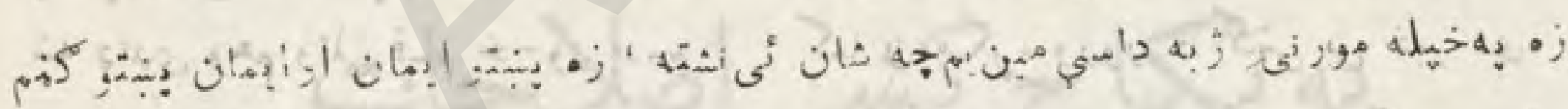
i i

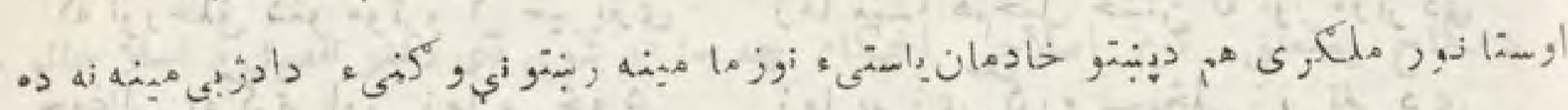
, مز

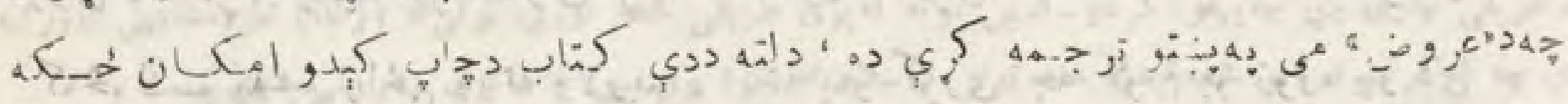

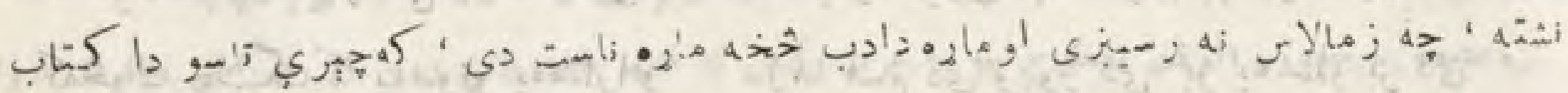

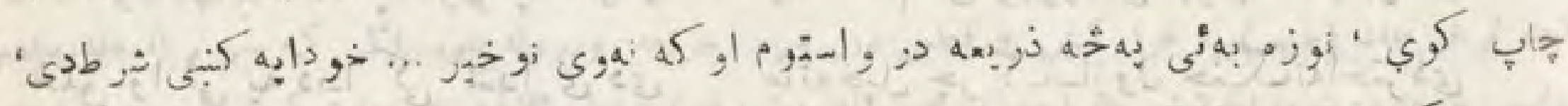

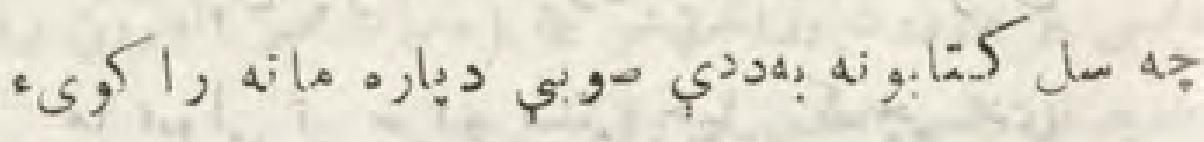

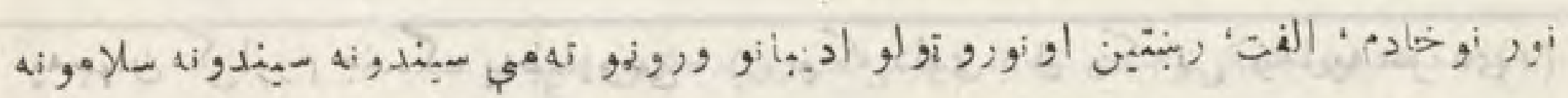

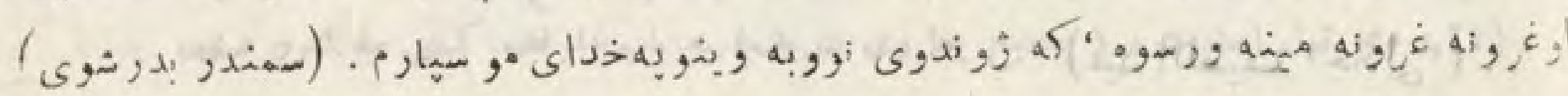




$$
\text { s, tis glo }
$$

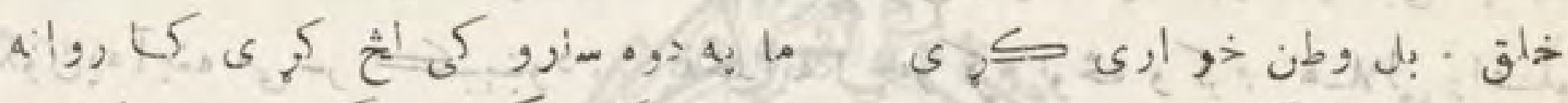

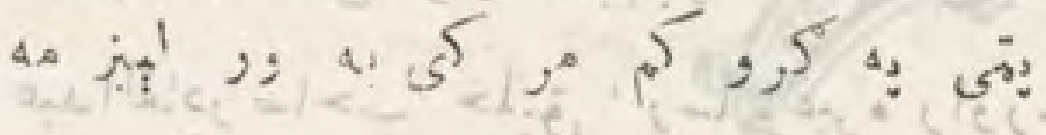
ai, ك. كن

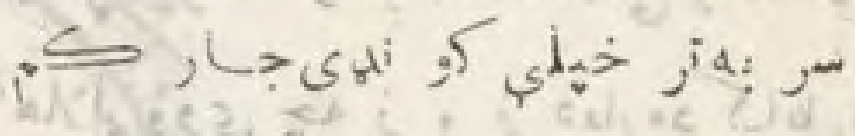

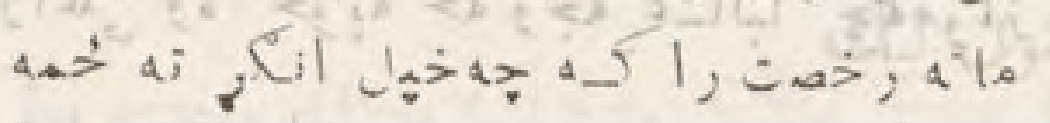

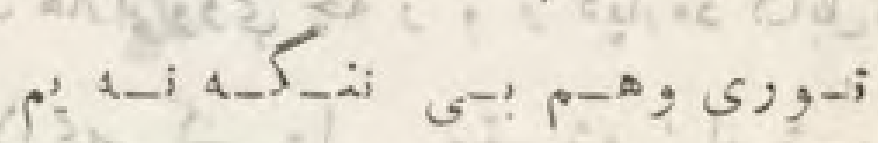

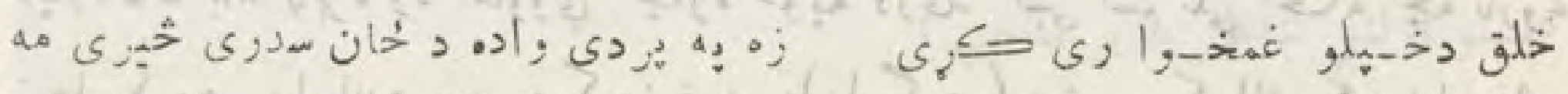

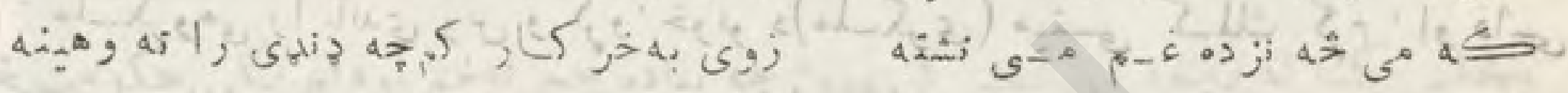
هi. a. o.

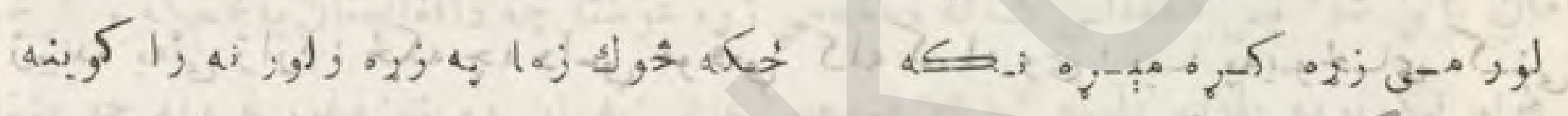

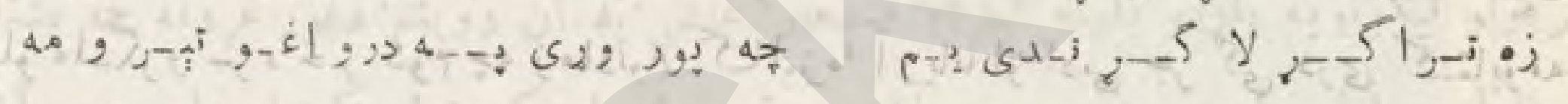

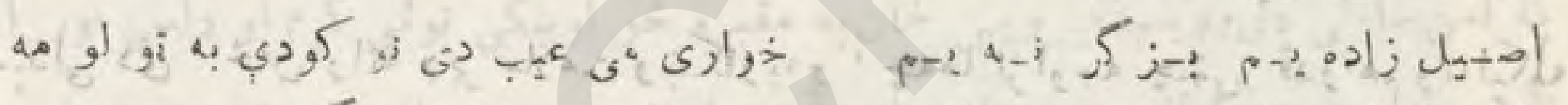
a a

(s)

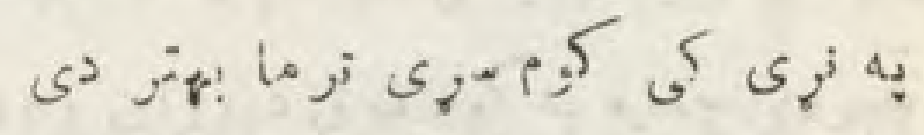

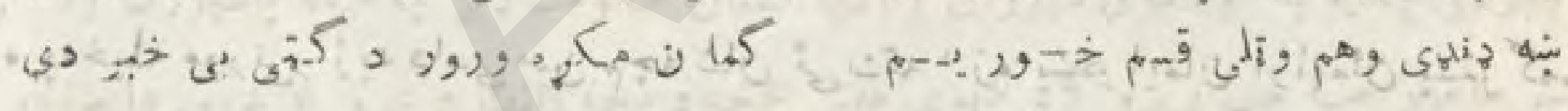

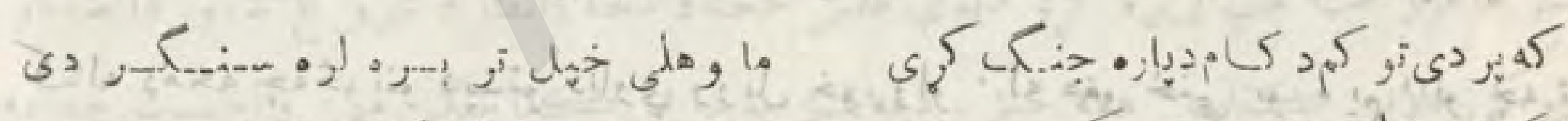

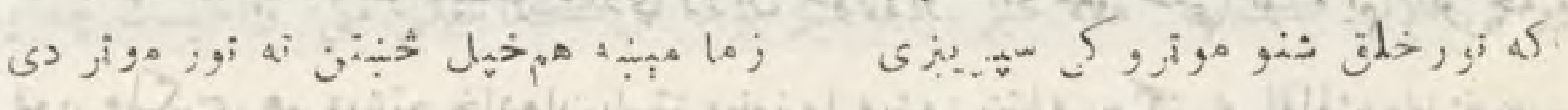

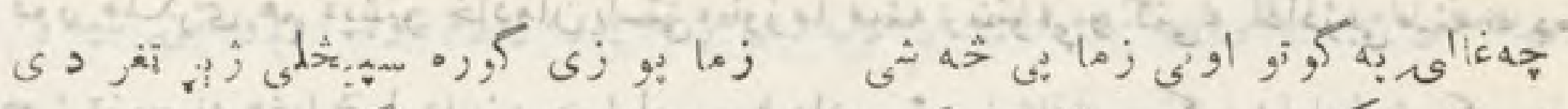

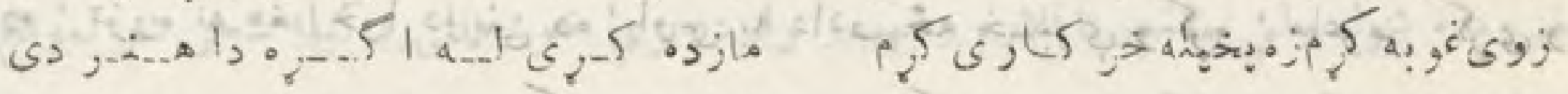

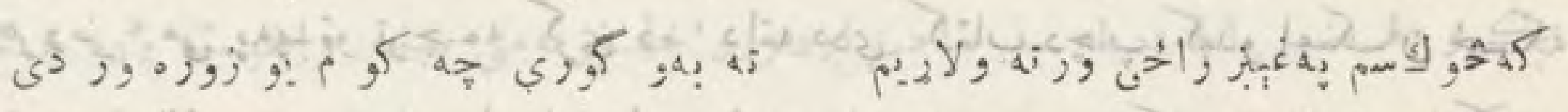

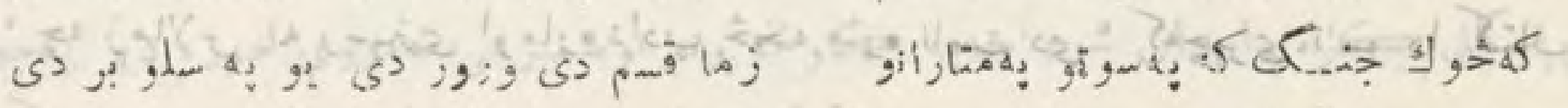

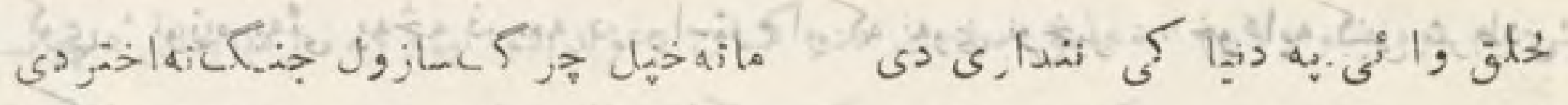

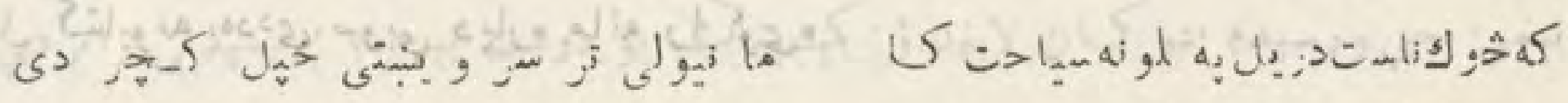

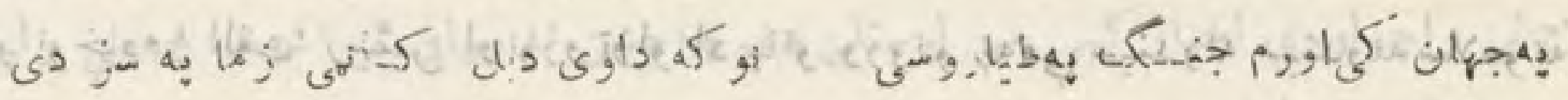

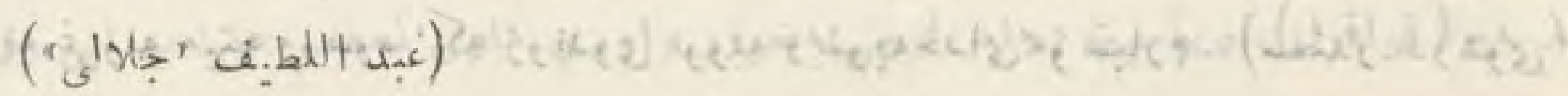




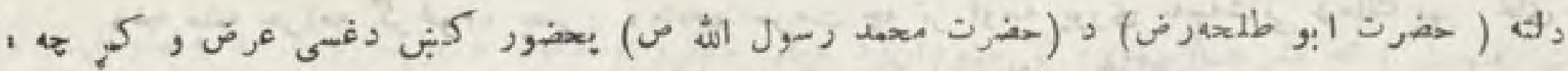

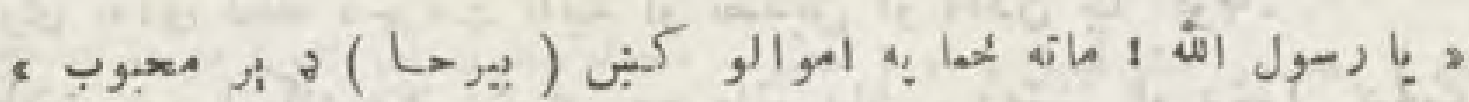

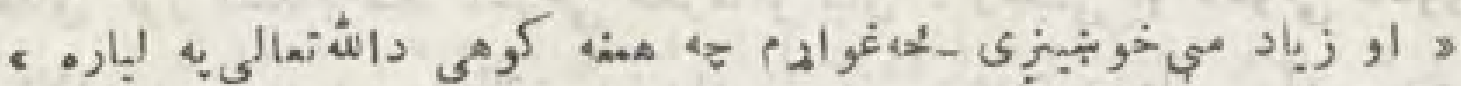

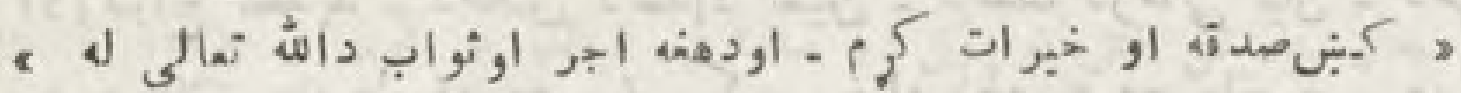

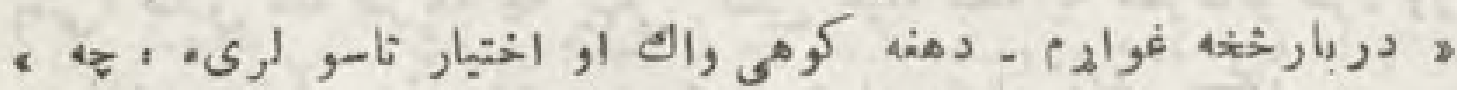

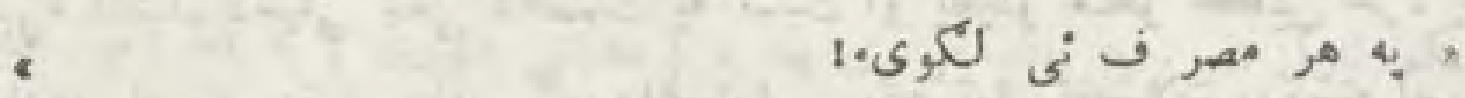

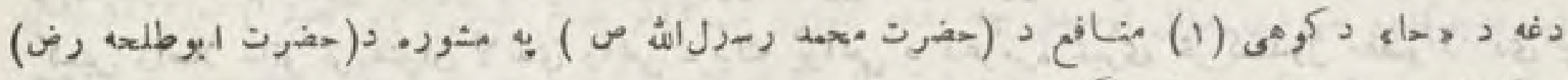
ير ئز

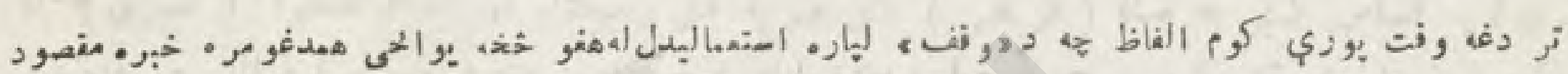

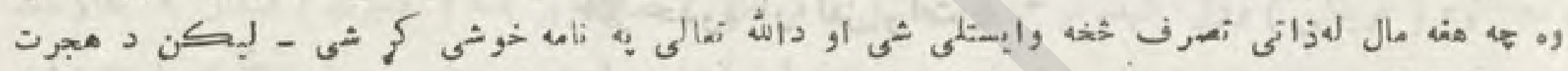

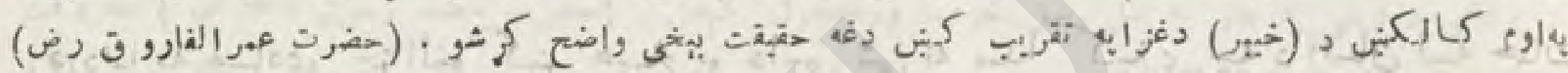

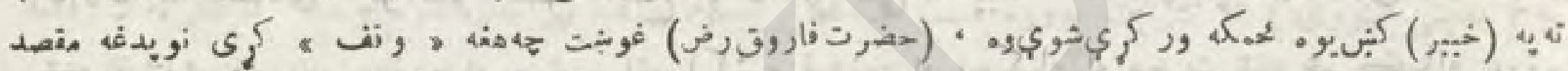

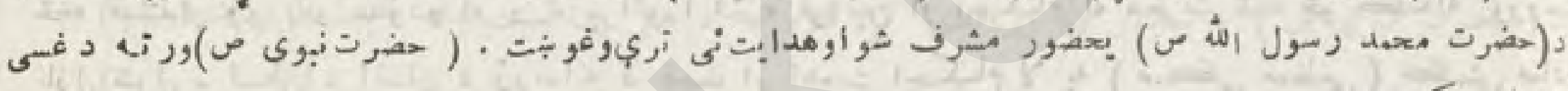
ا إشاد,

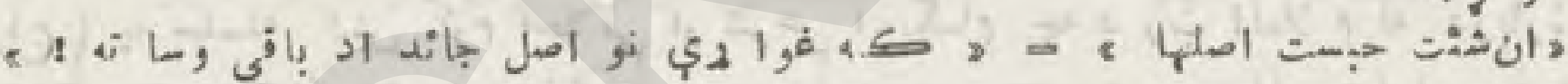
" I. أ

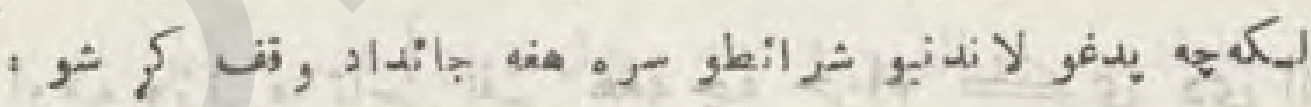

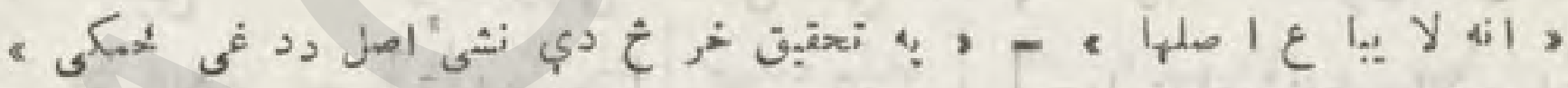

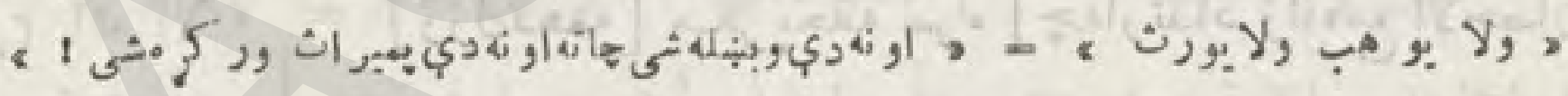
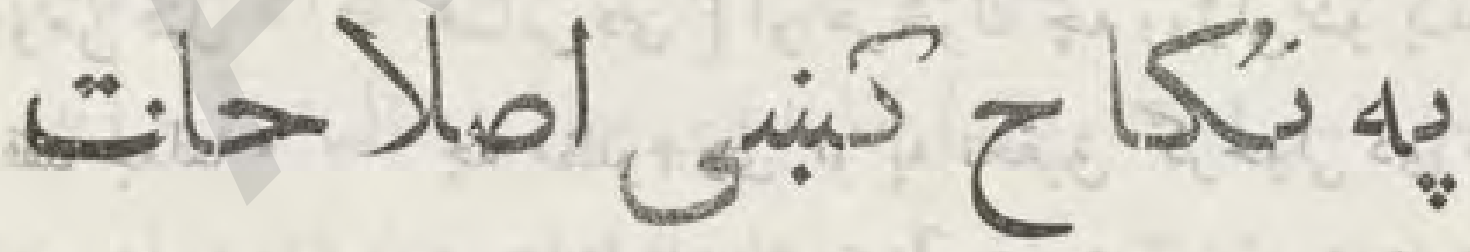

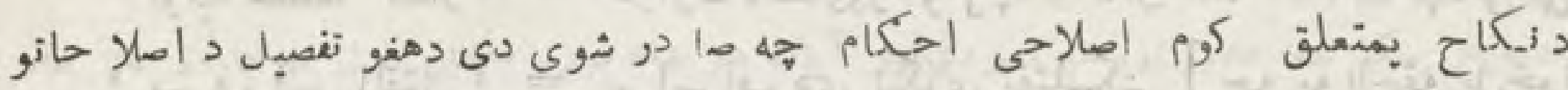

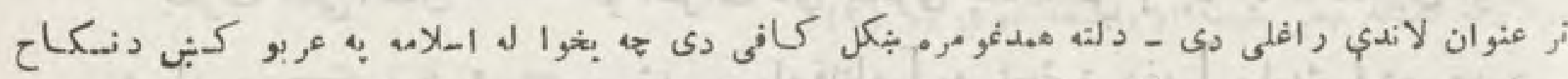

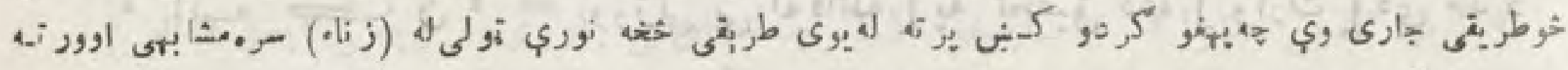

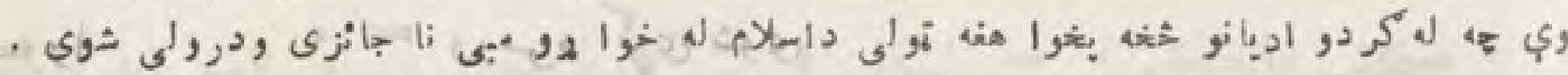

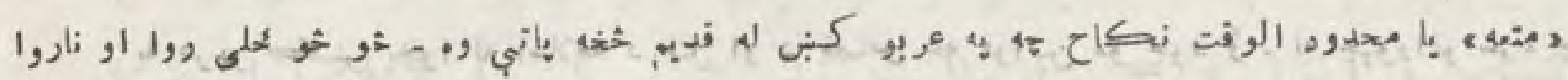

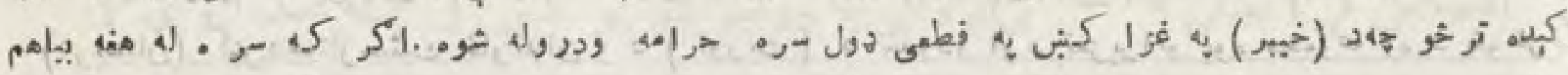

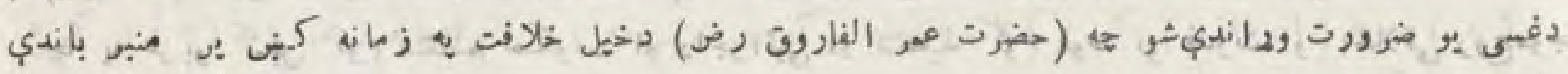

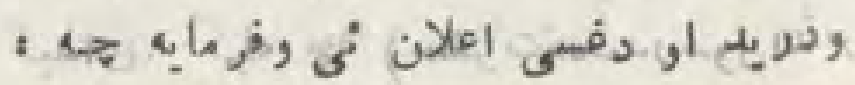


أه

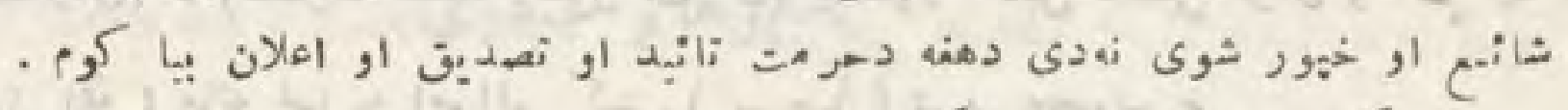

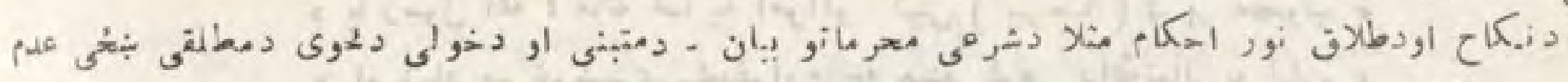

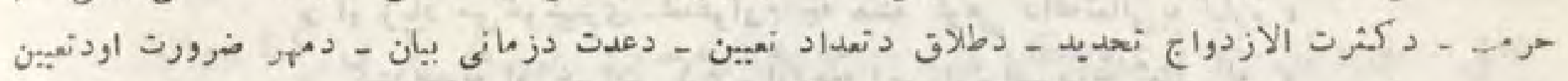

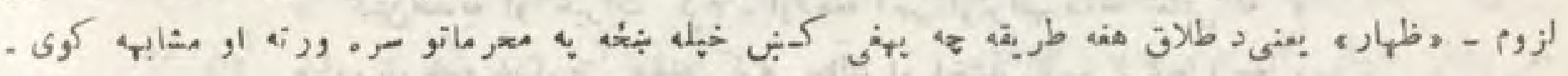

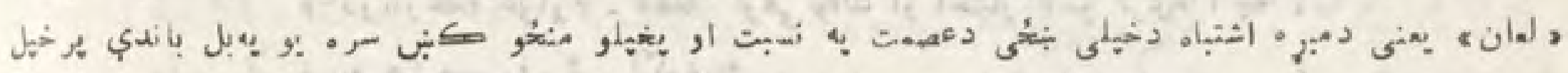

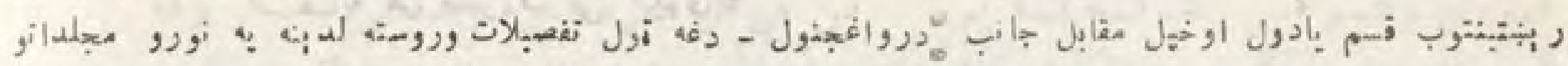

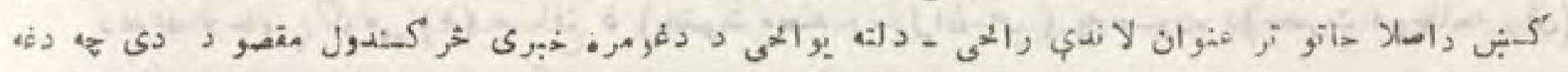

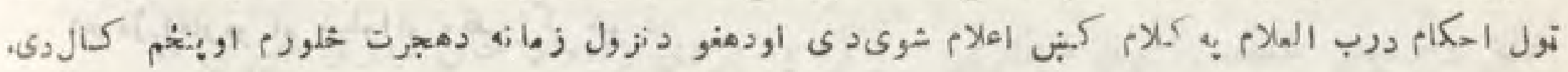

$$
\text { - : }
$$

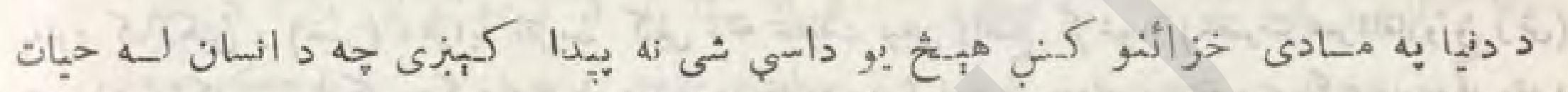

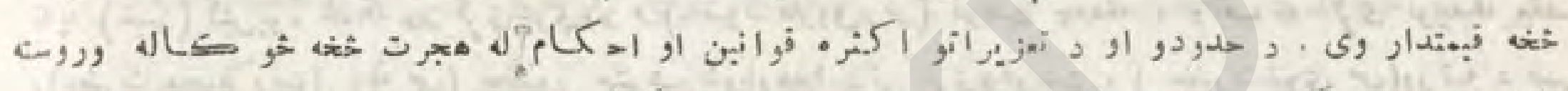

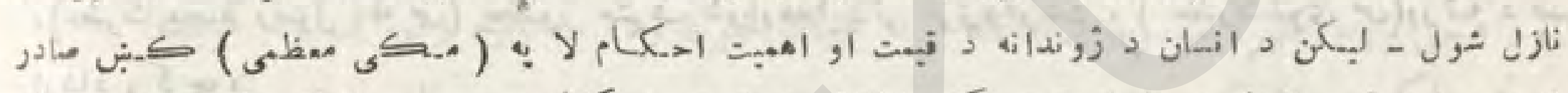

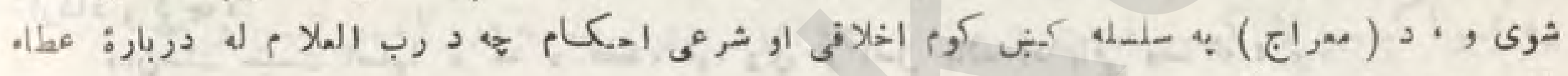

$$
\text { (1) و (1) }
$$

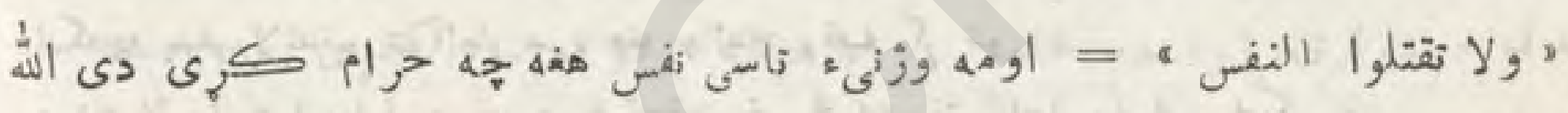

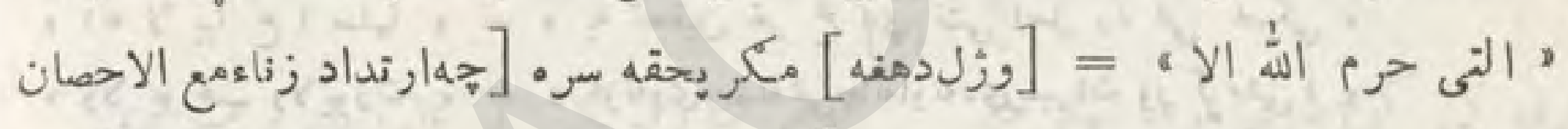
' بالحق ' ومن قتل "

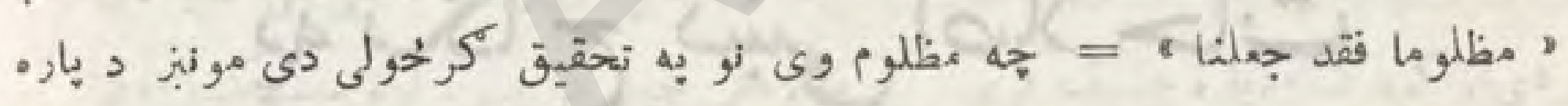

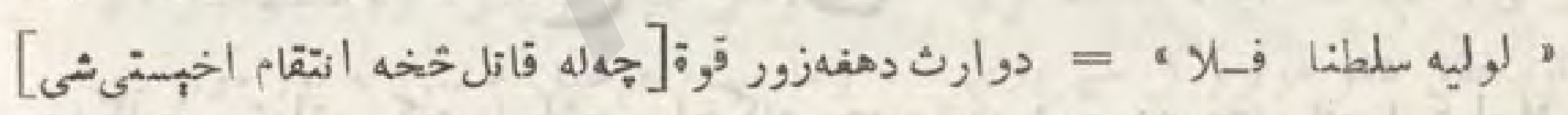

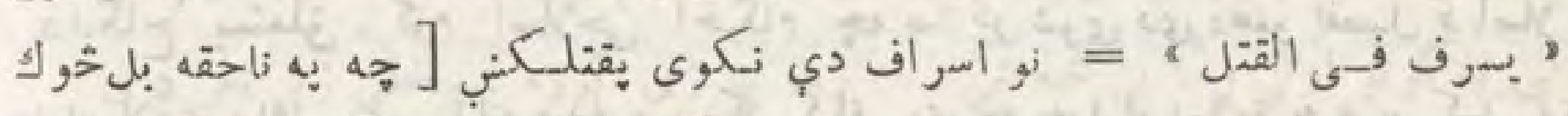

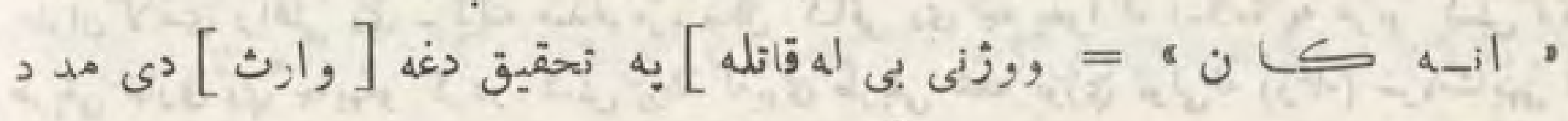

$$
\text { . }
$$

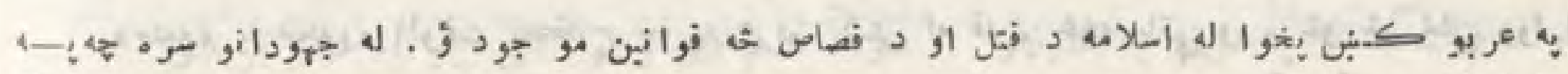

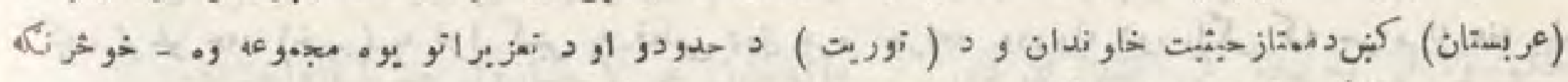

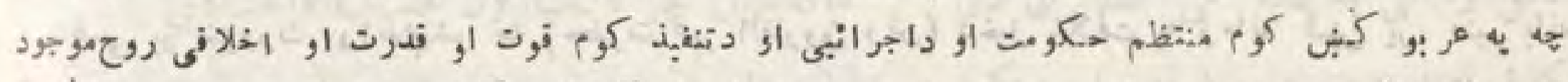

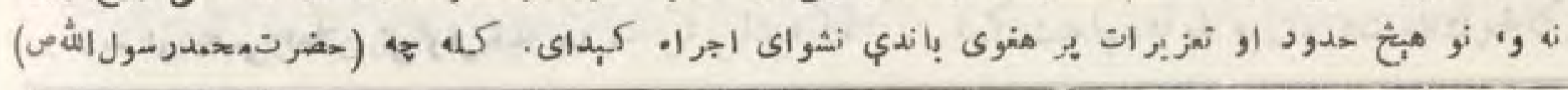

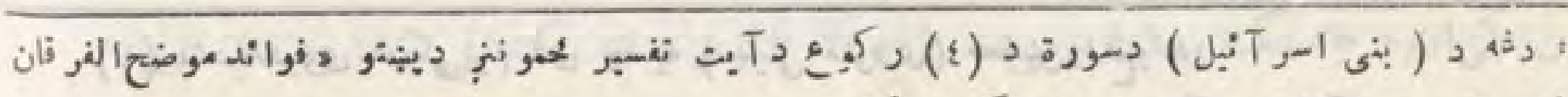
كابلى 


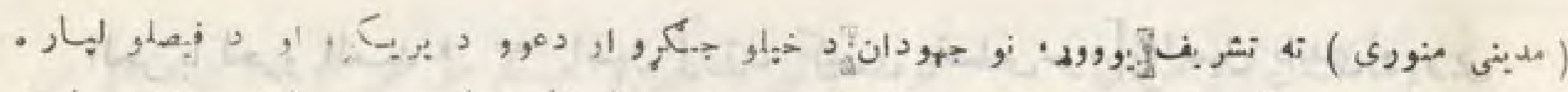

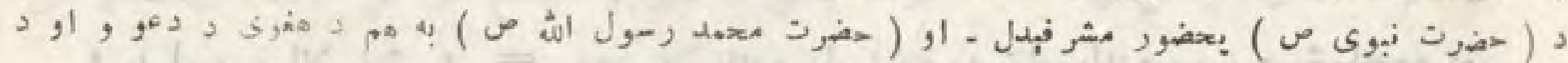

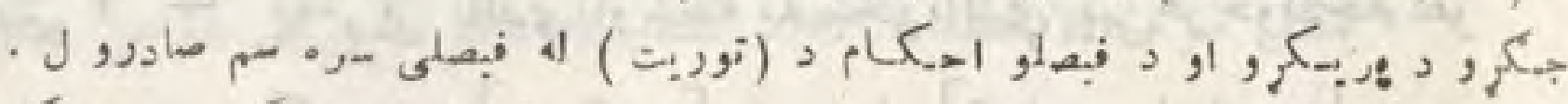

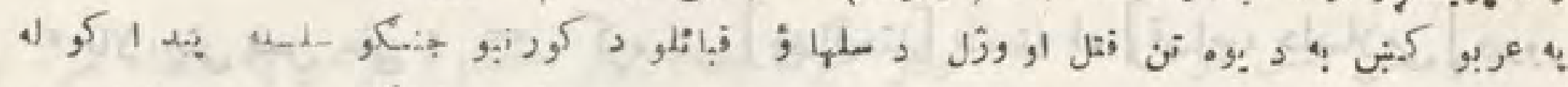

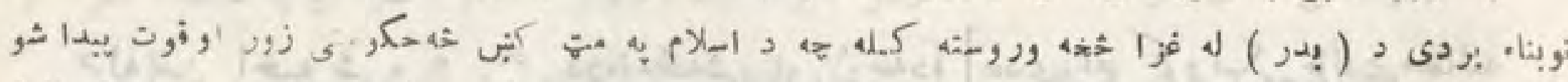

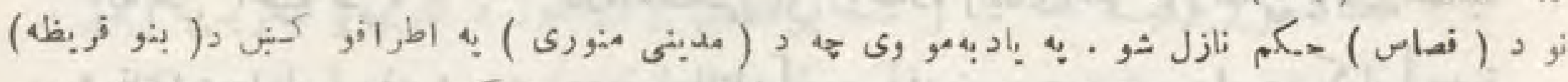

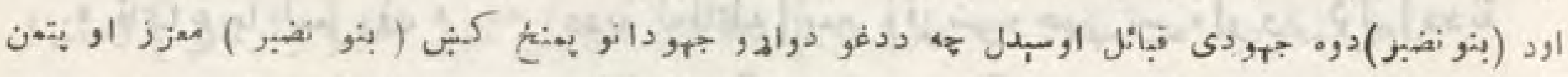
une

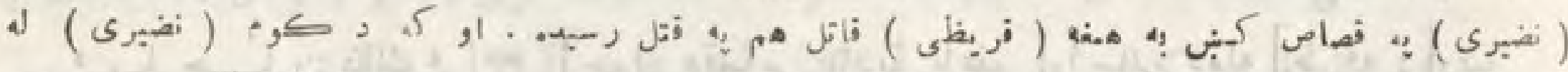

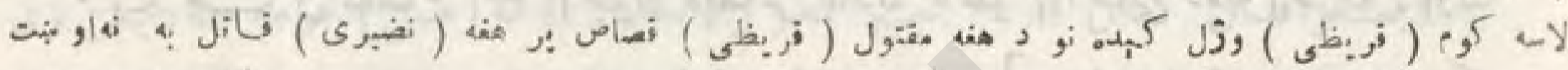

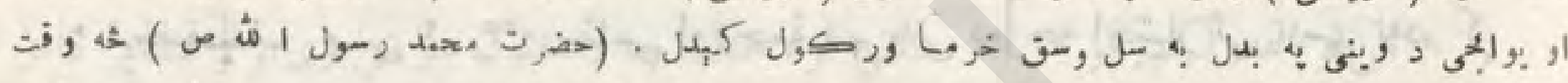

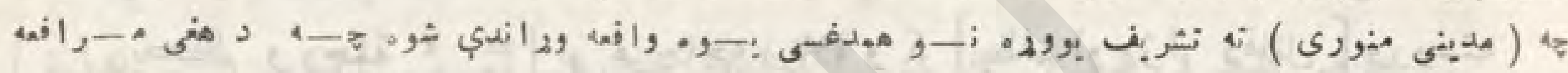

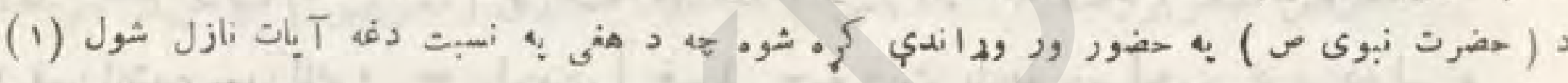

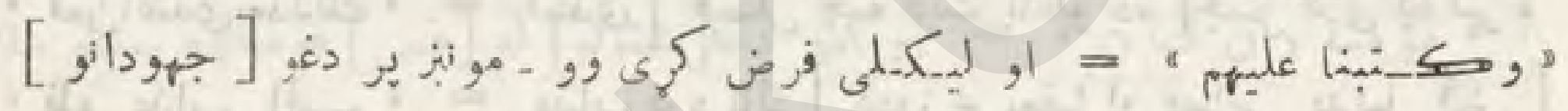

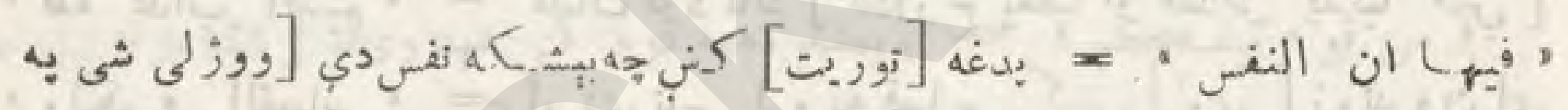

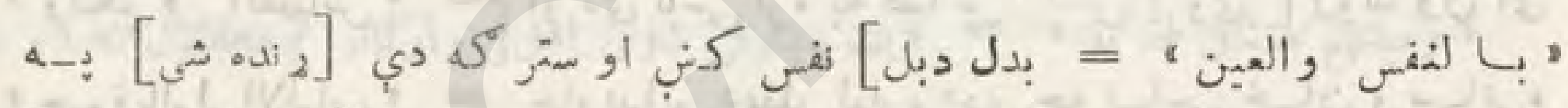

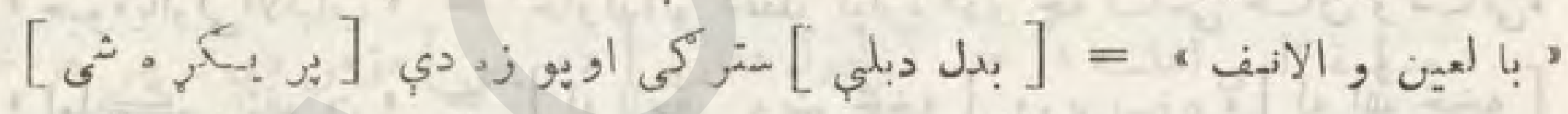
" بالا نف والازن " "

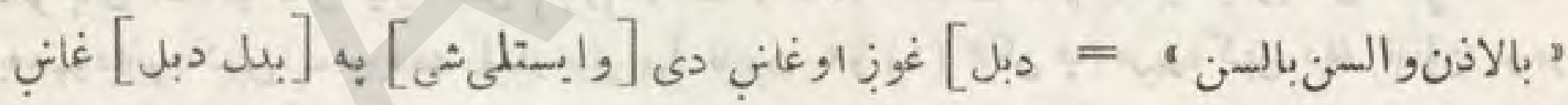

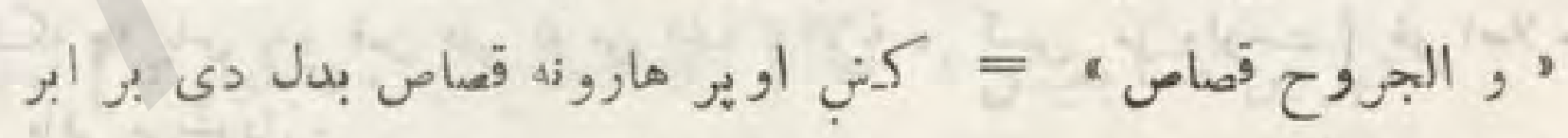

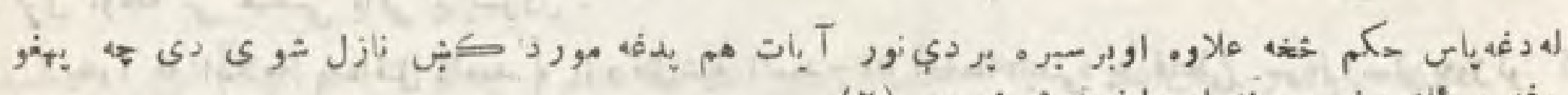

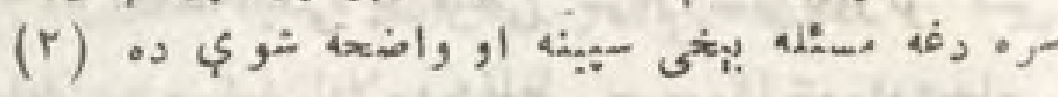

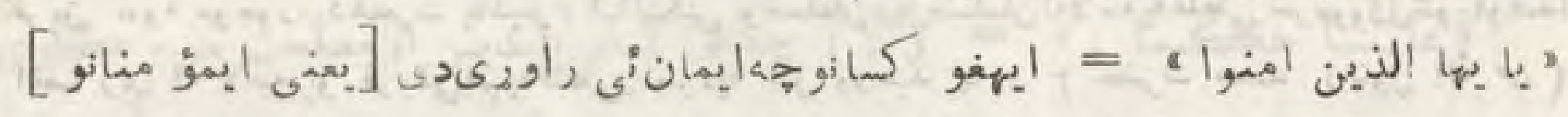
"

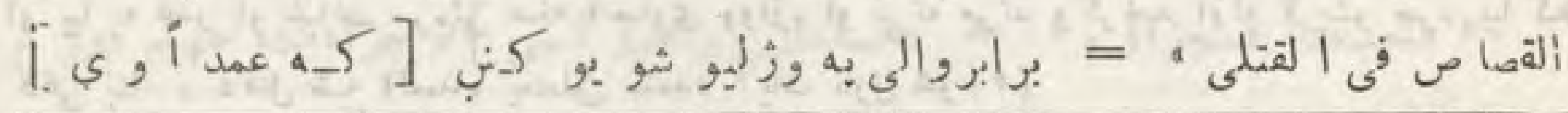

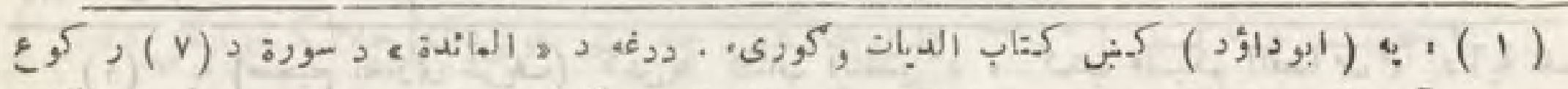

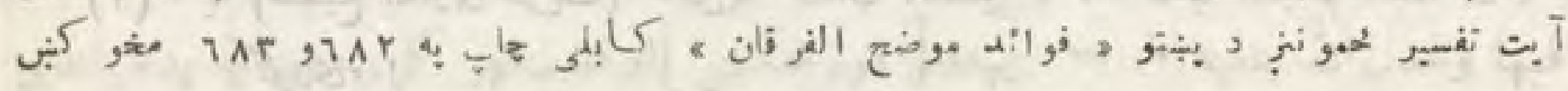

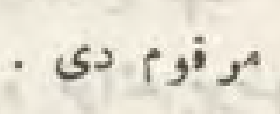

(r)

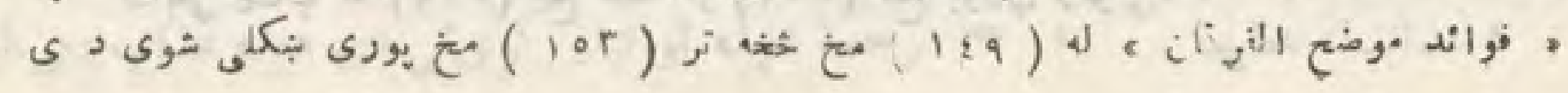




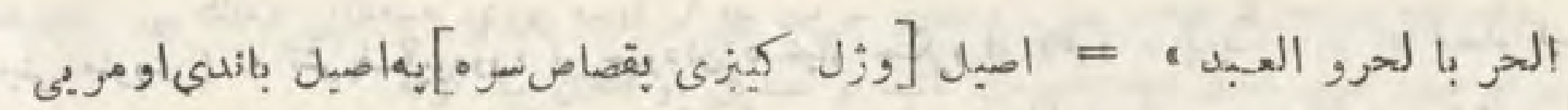

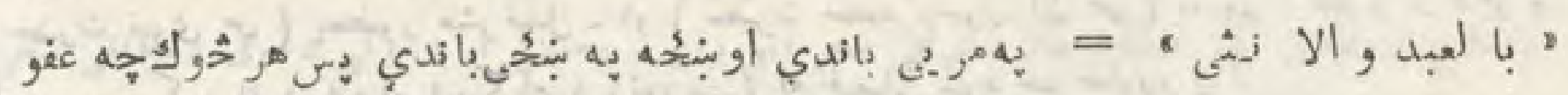
"بالا نشى فمن عنى "

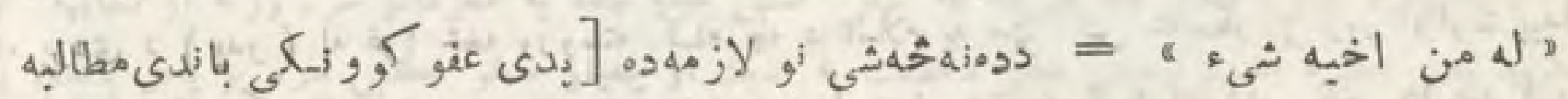

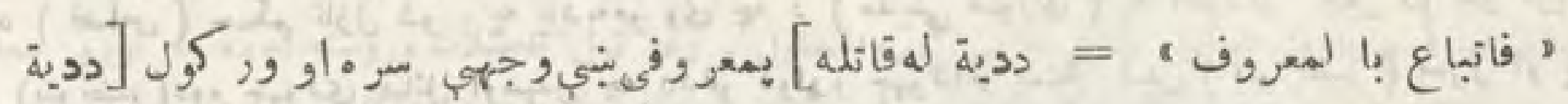

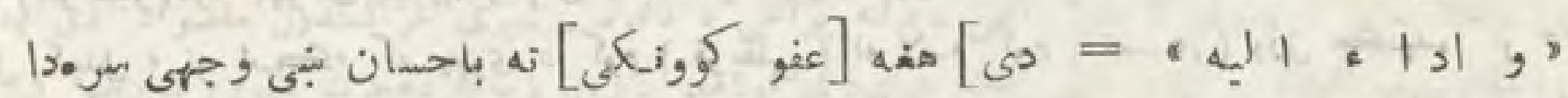

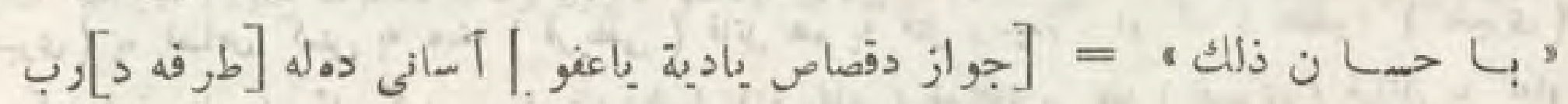

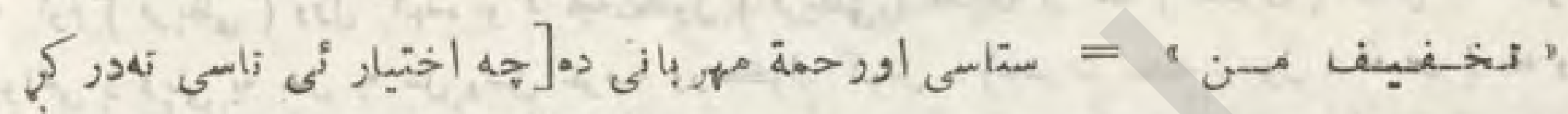

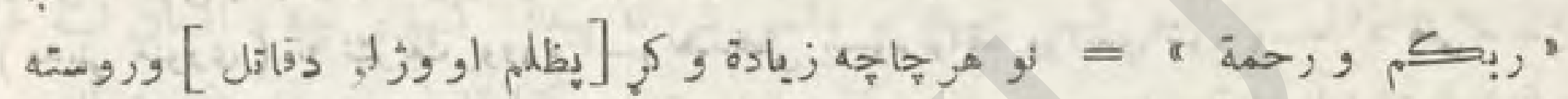

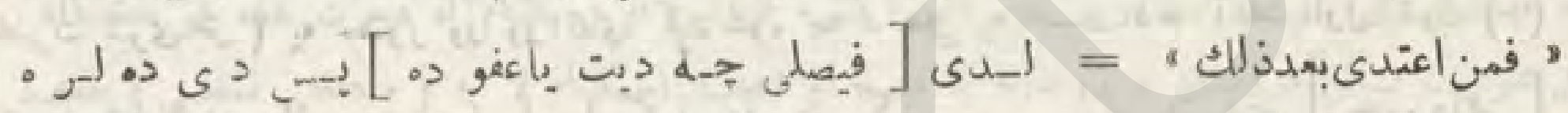

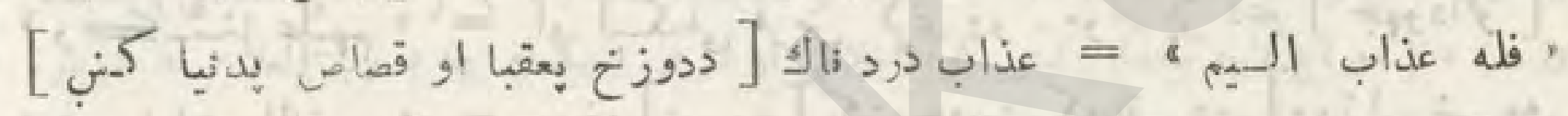

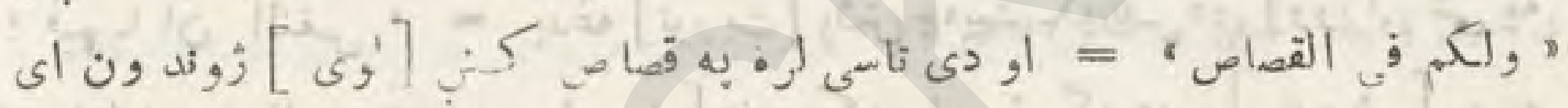

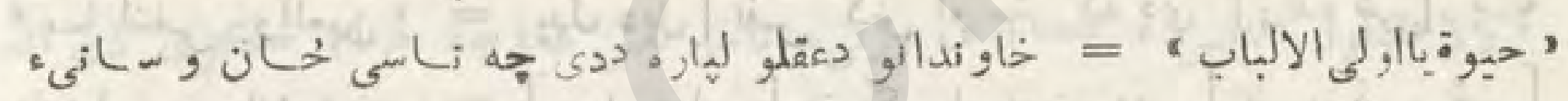
[

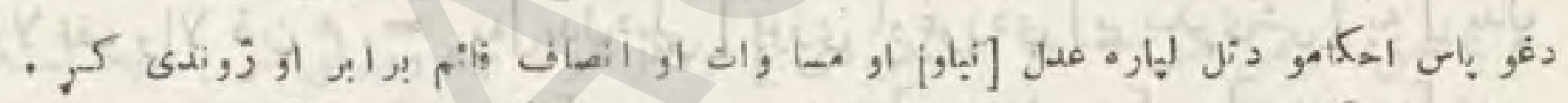

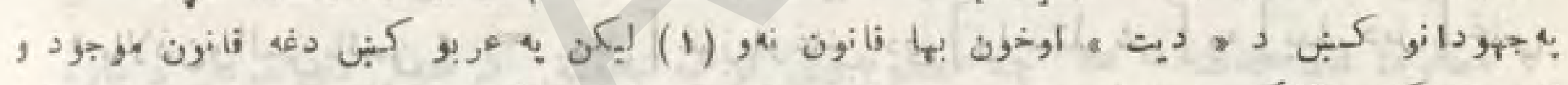

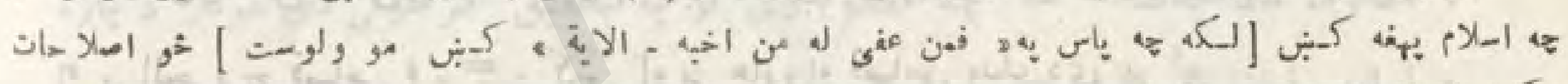

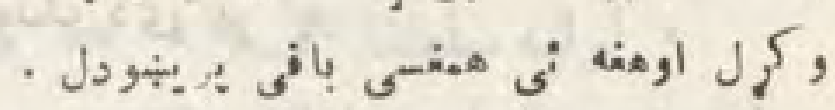

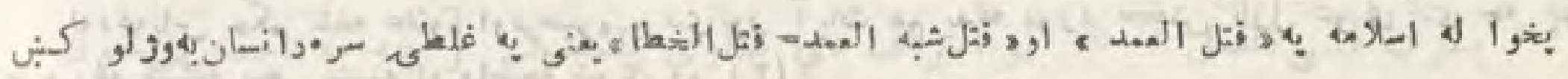

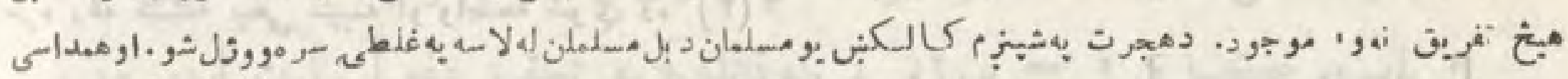

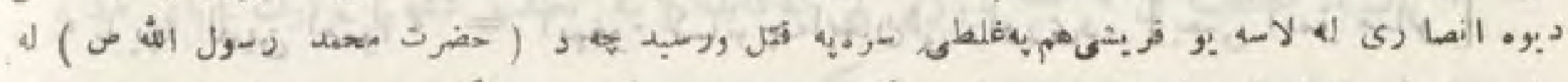

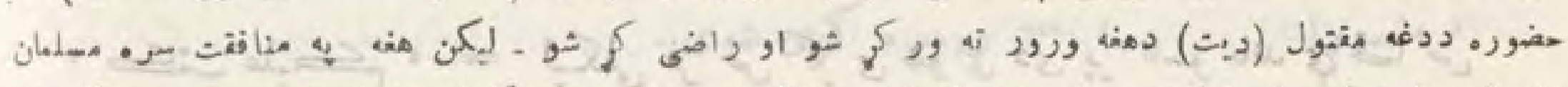

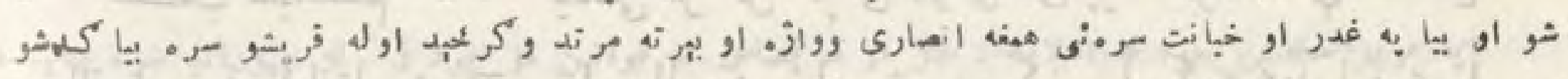

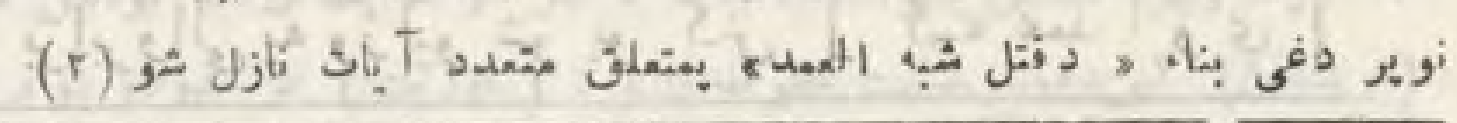

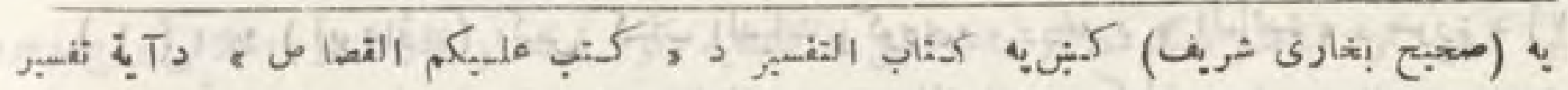

$$
1.5,5
$$

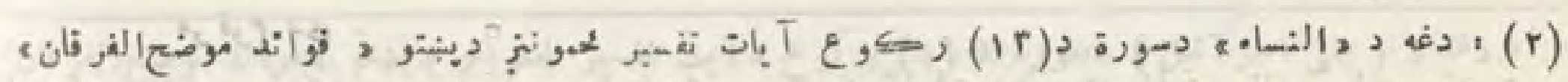

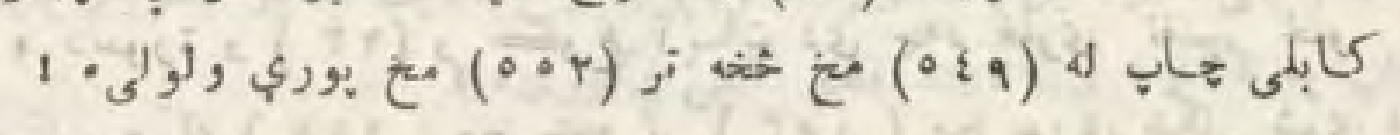




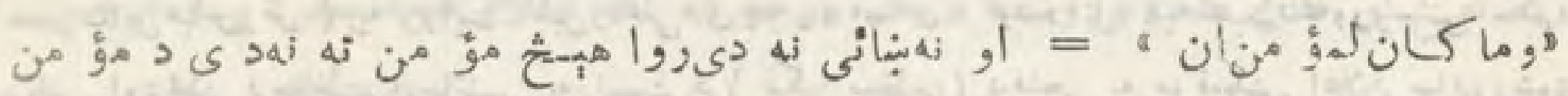

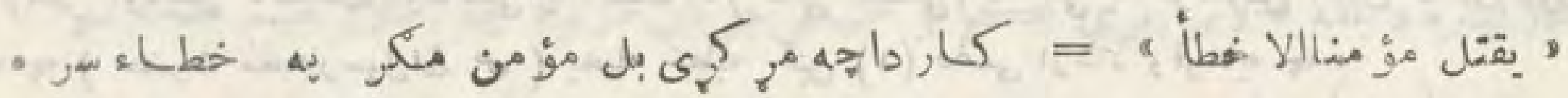

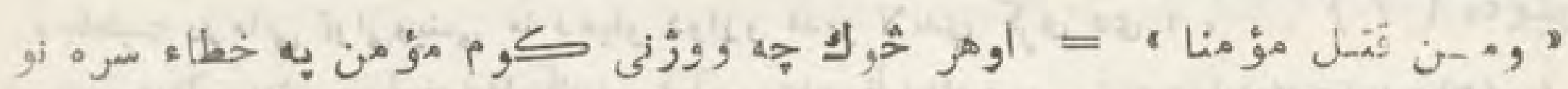

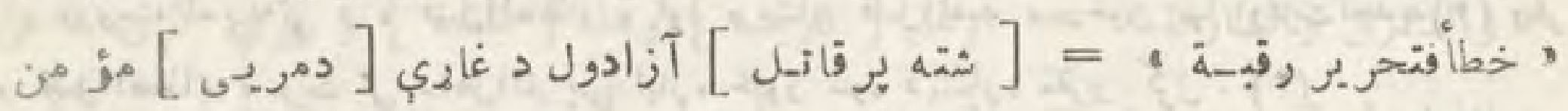

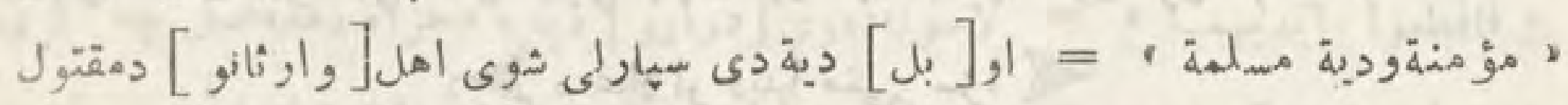

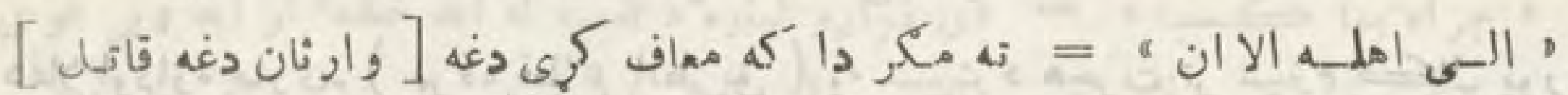

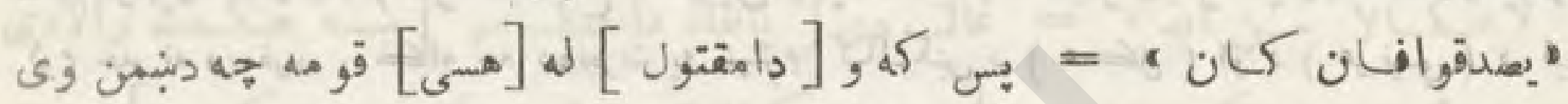

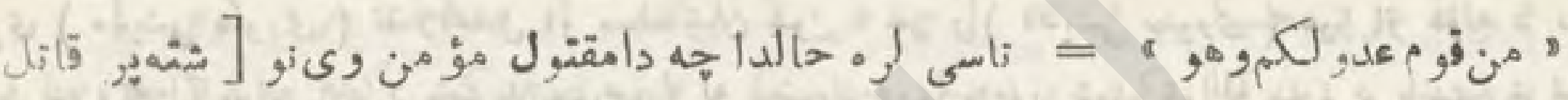

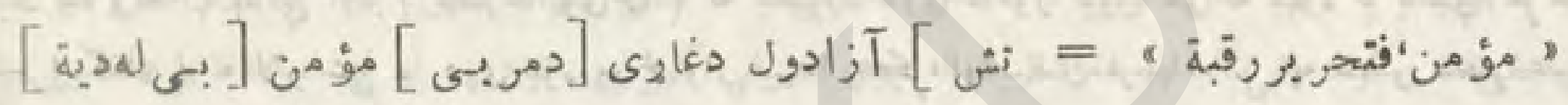

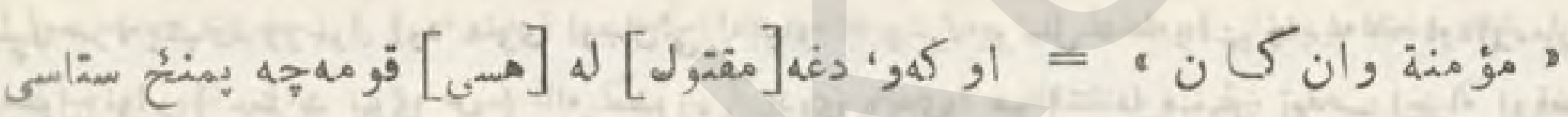

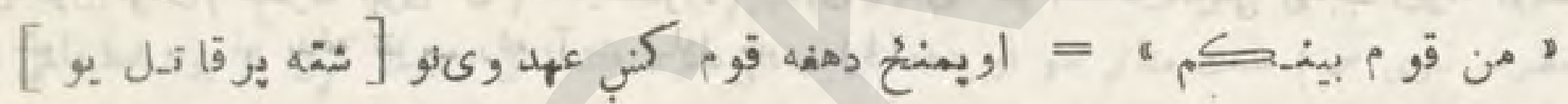

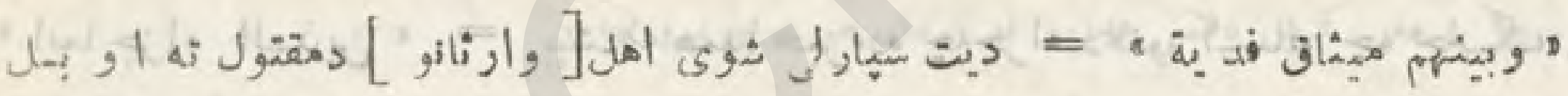

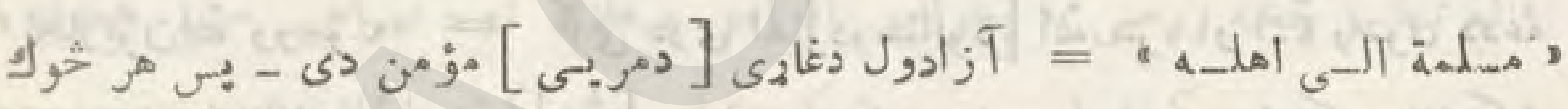

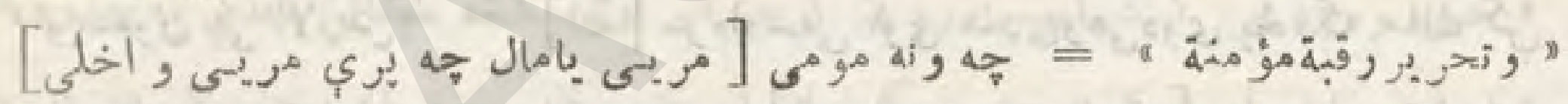

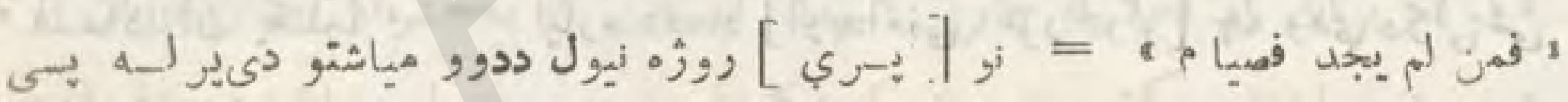

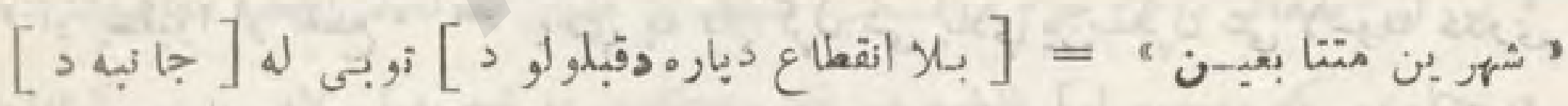

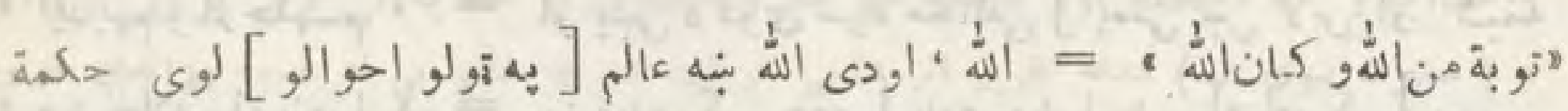

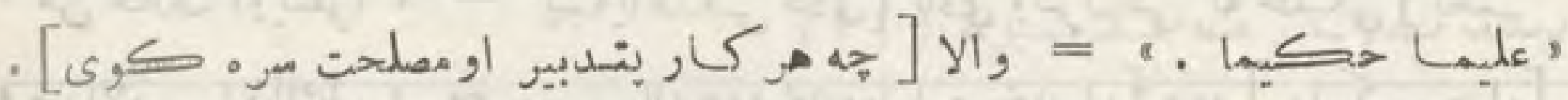

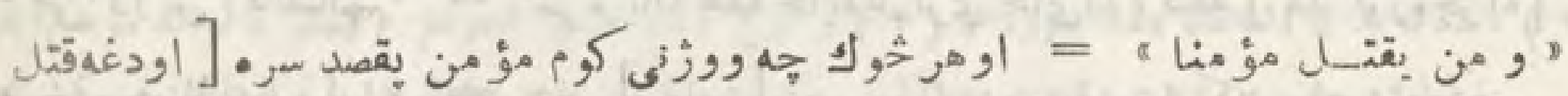

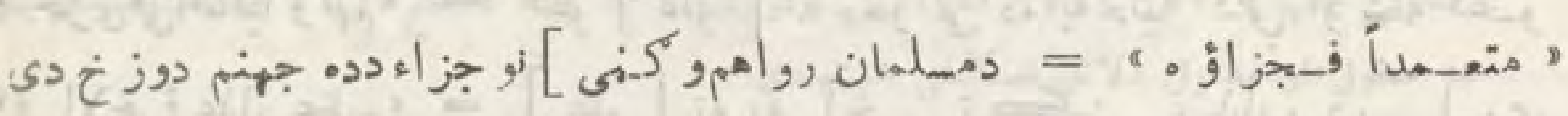
[

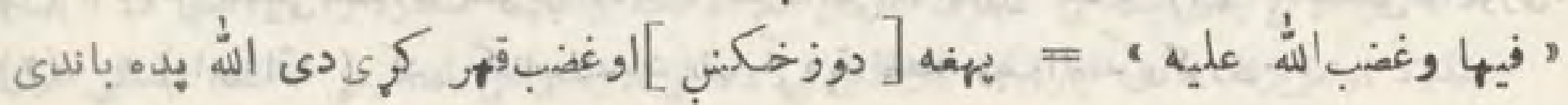

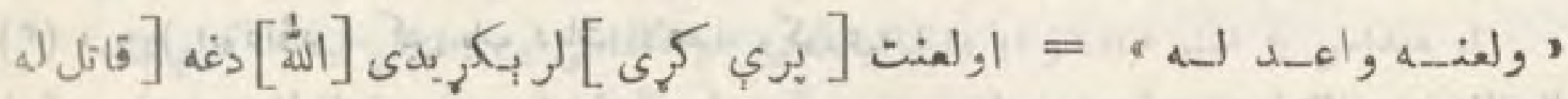

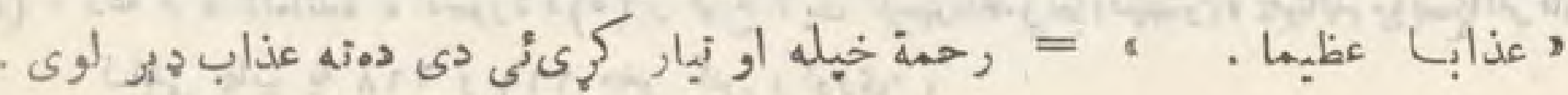




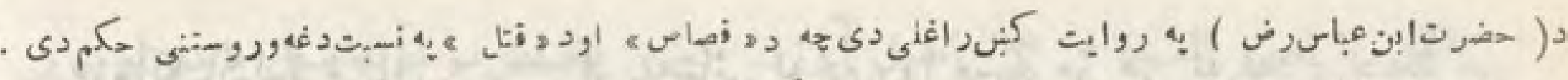

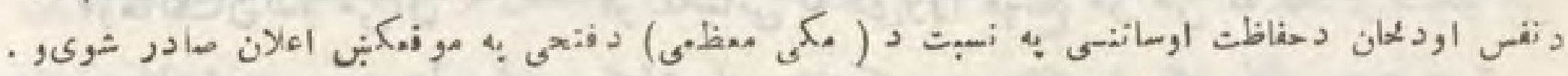

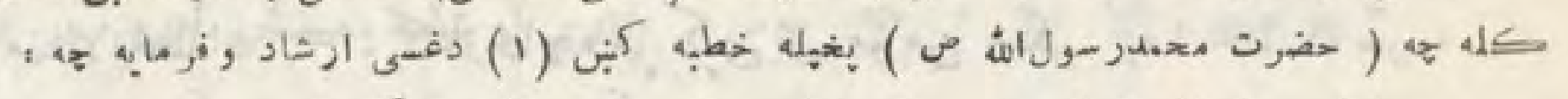

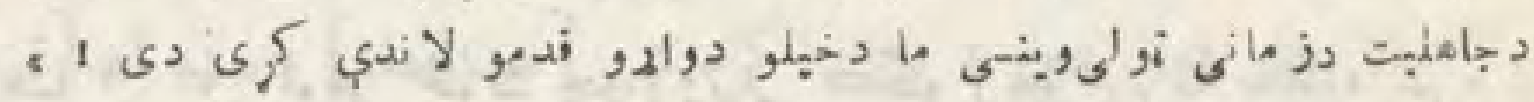

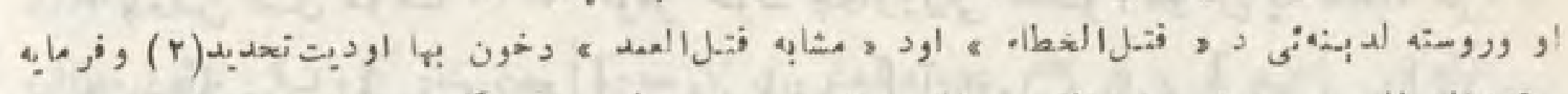

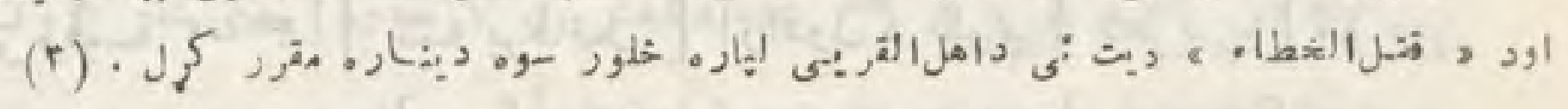

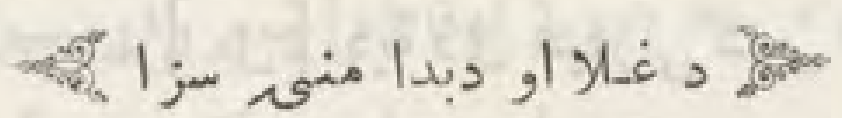

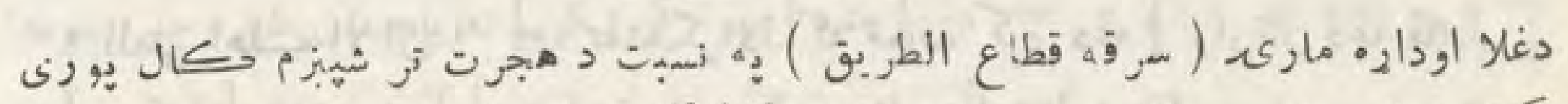

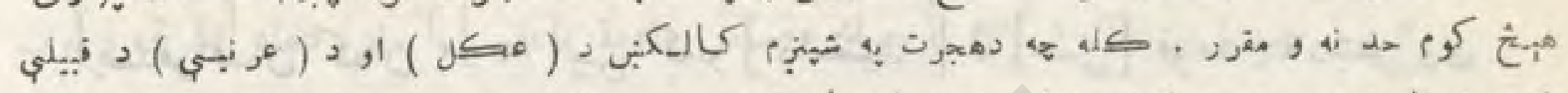

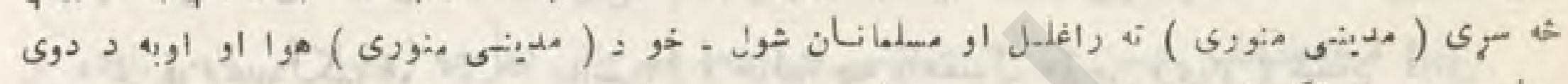

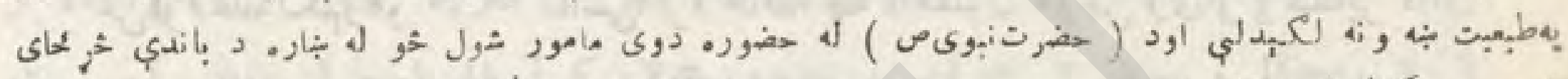

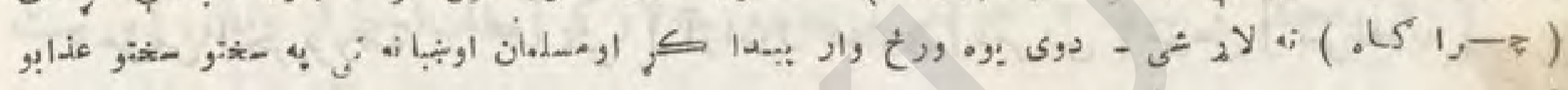

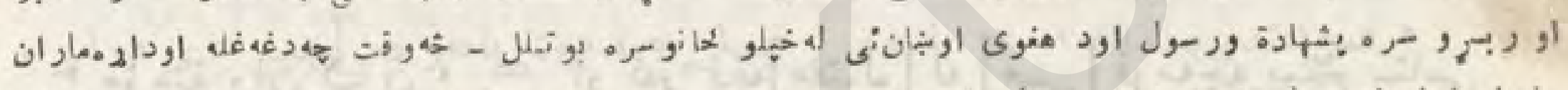

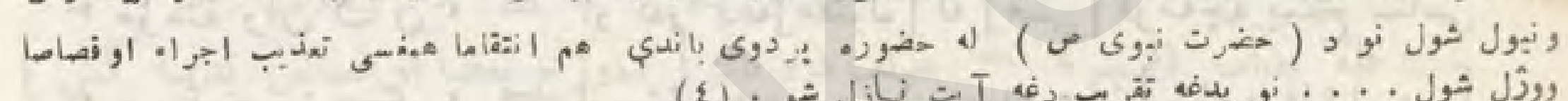

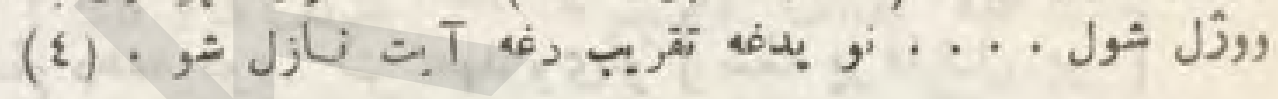

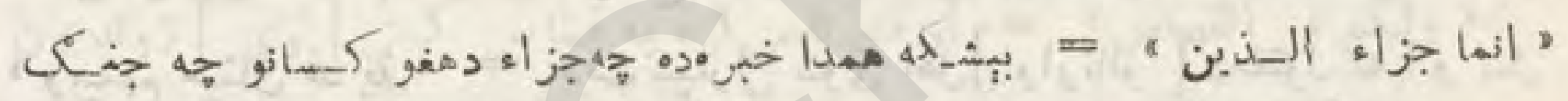

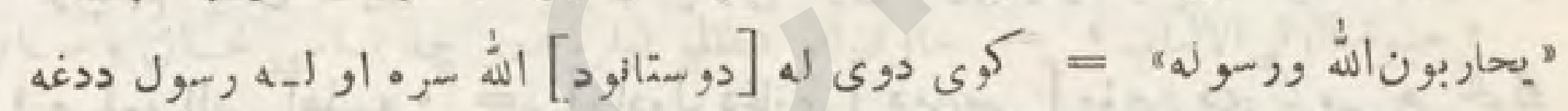

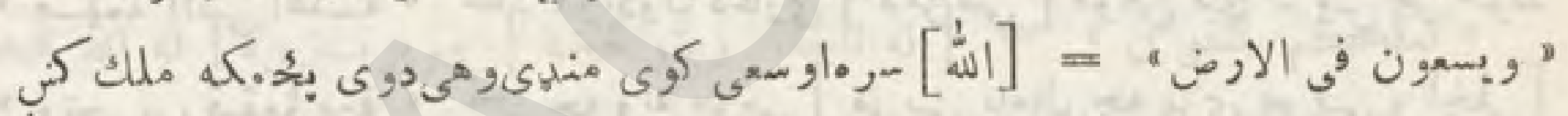

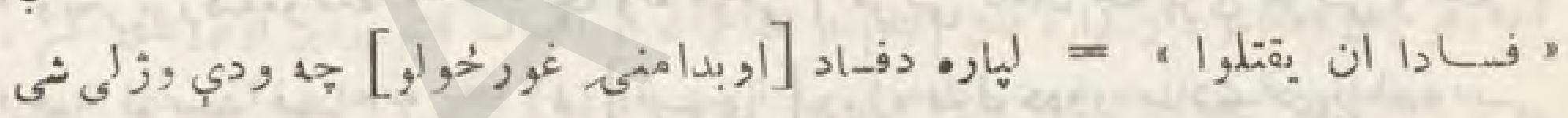

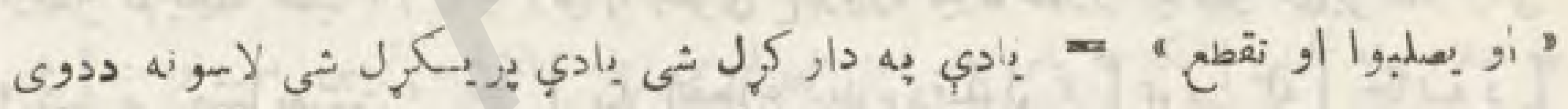

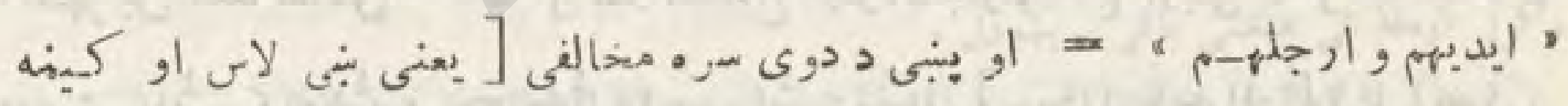
"من خالاف أوينفوا "

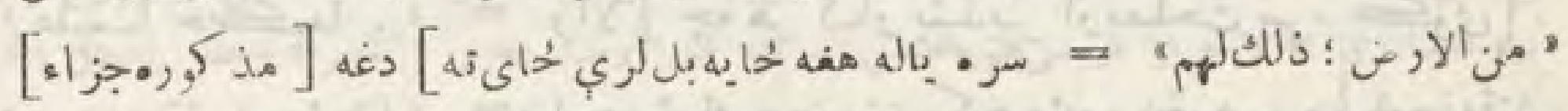
"خزى في الدنيا وله" لهي" "فى الاخرة عنابعظهم" =

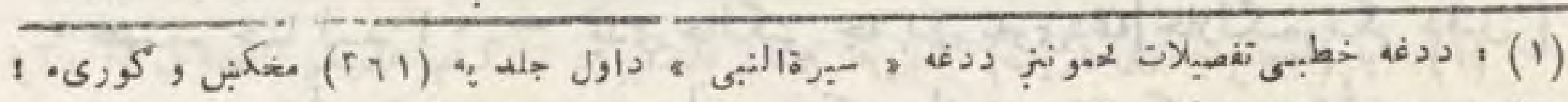

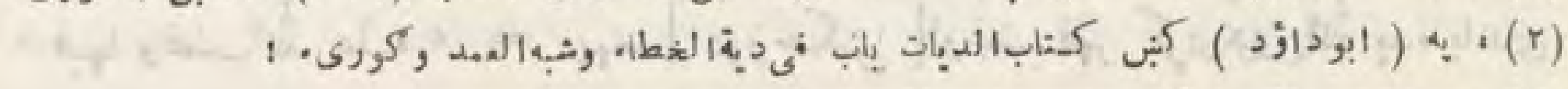

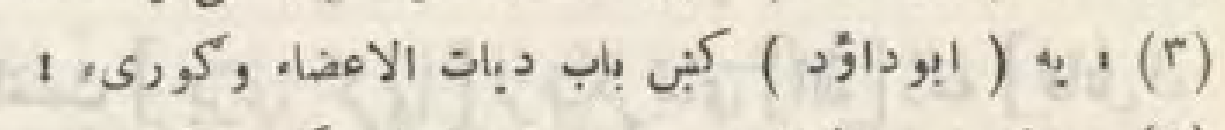

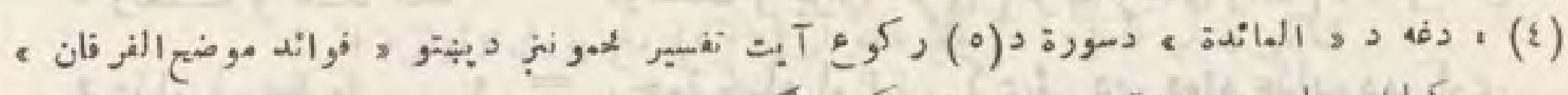
ك 


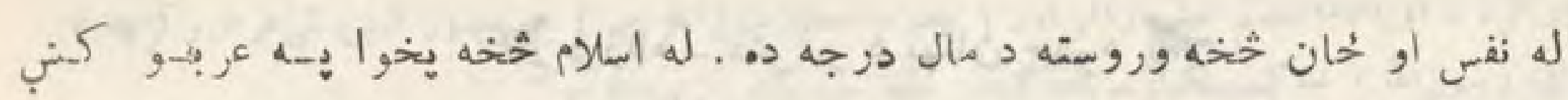

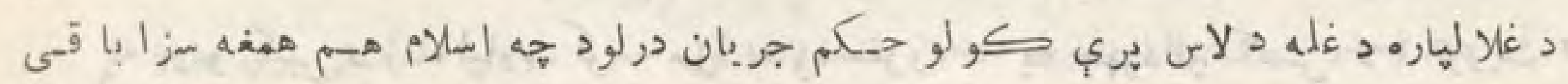

$$
\text { (1) }
$$

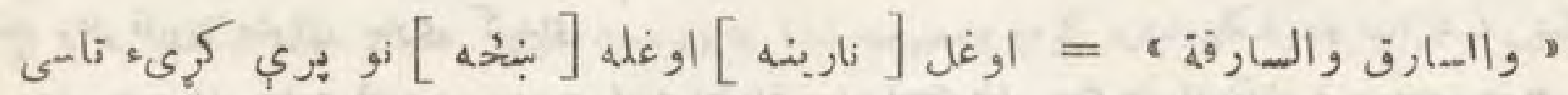

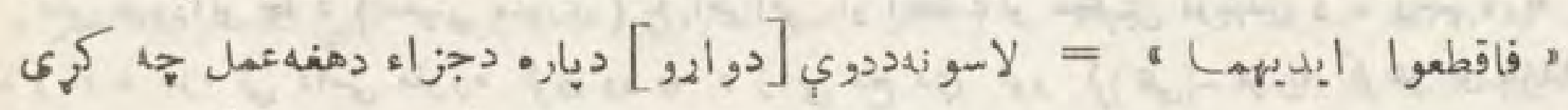

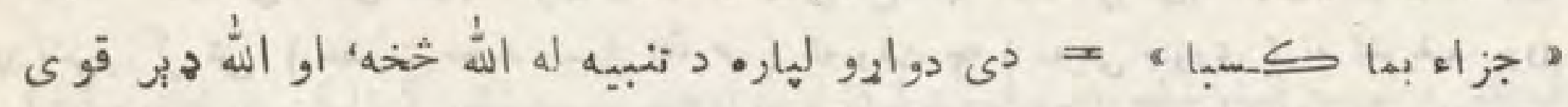

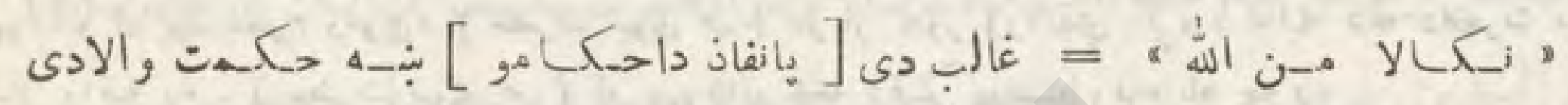

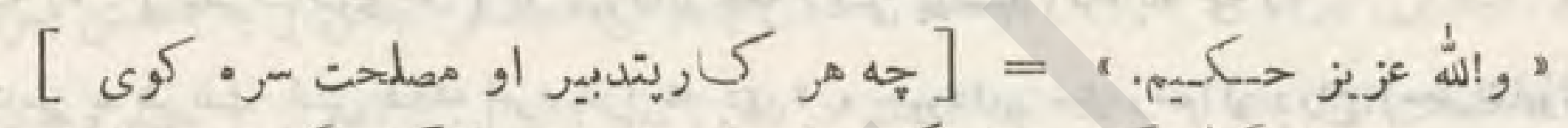

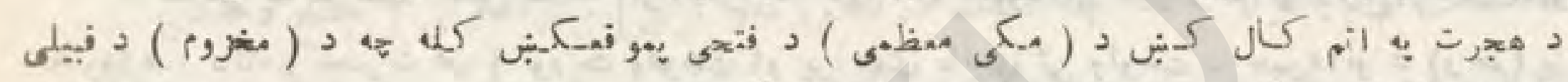

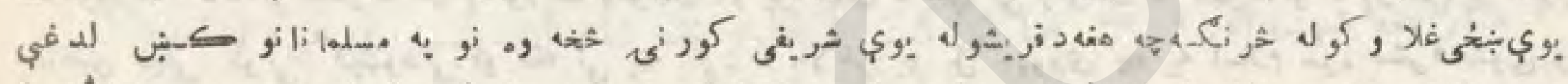

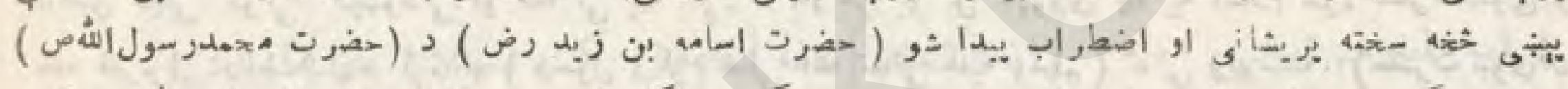

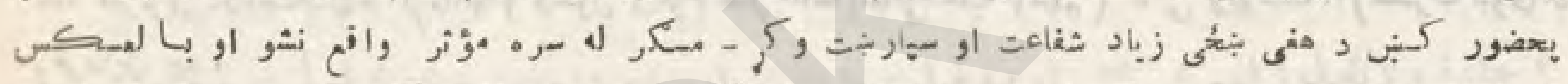

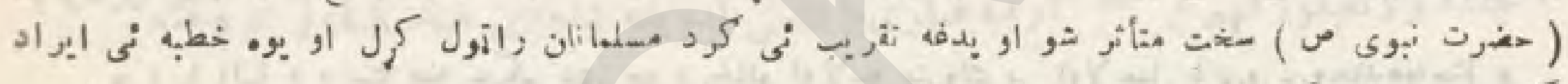

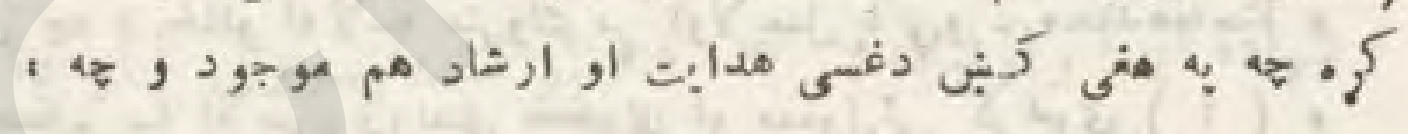

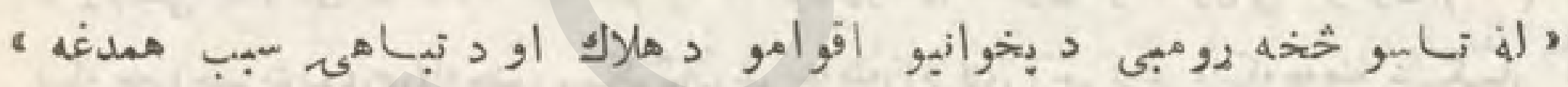

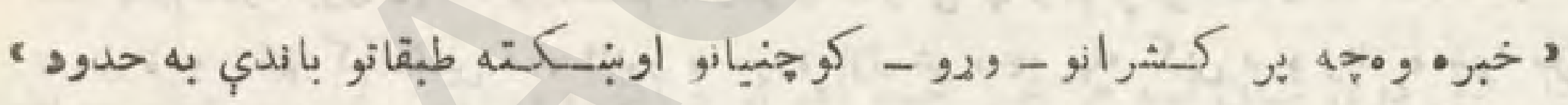

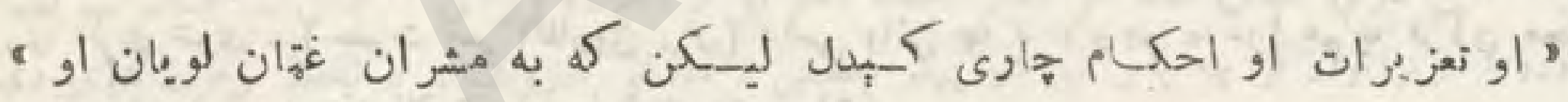

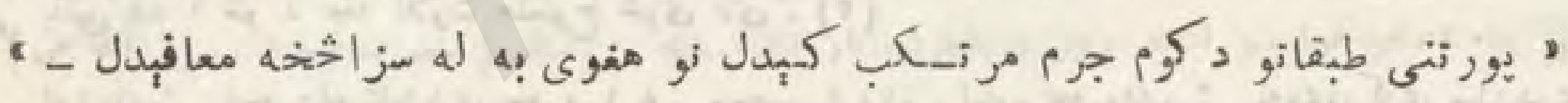

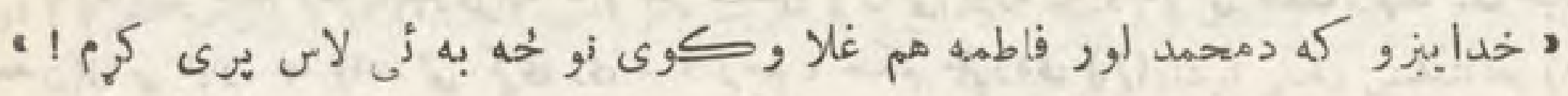

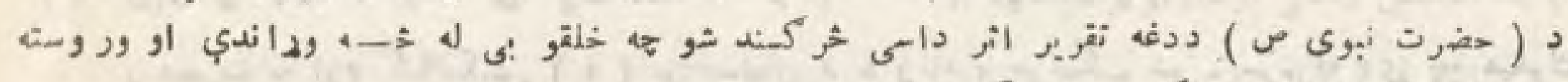

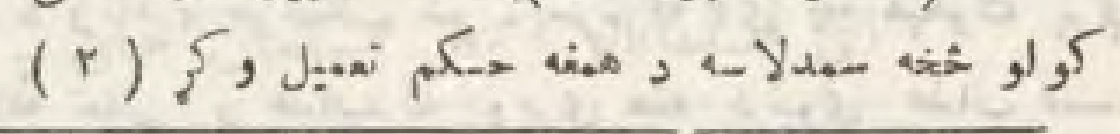

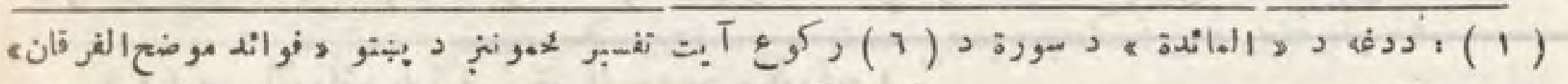

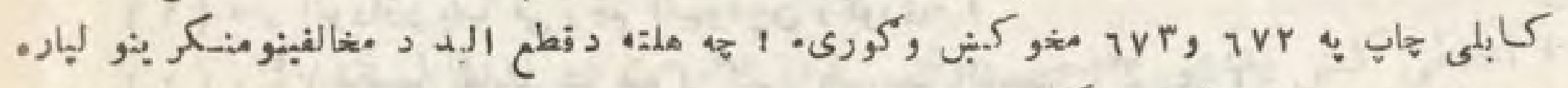

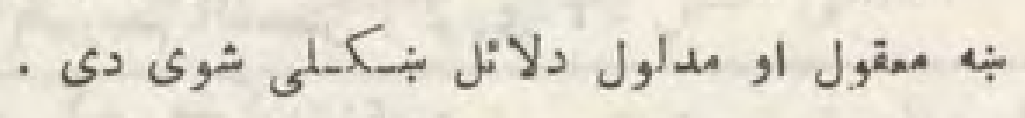

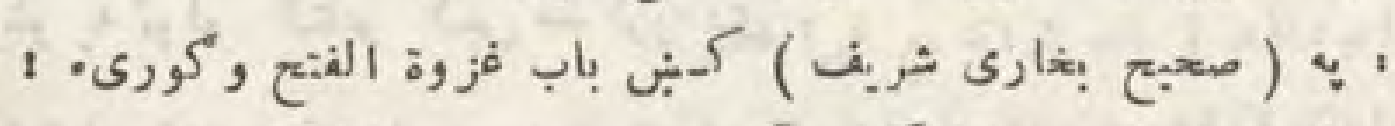

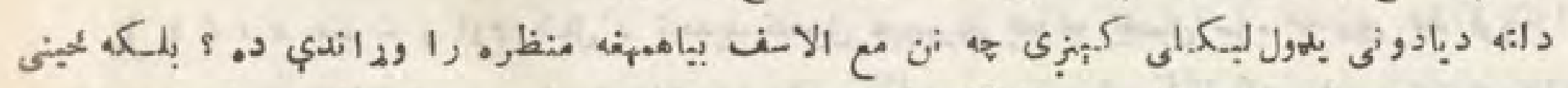

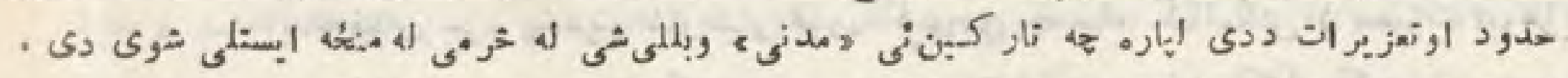

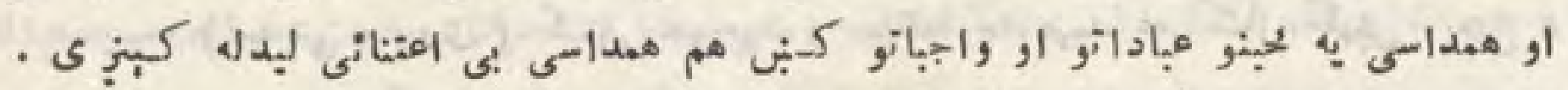

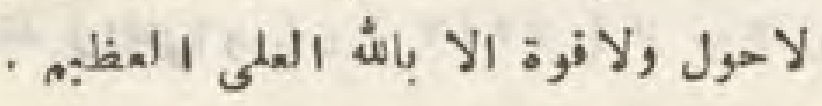




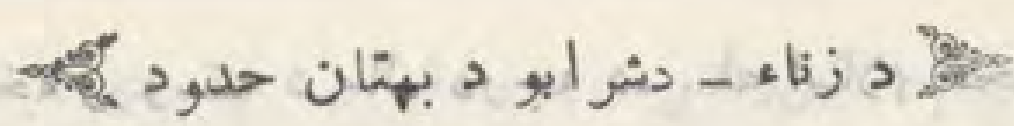

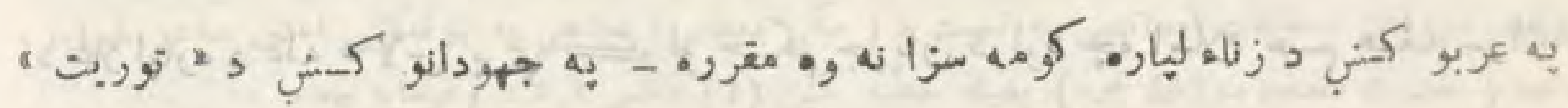

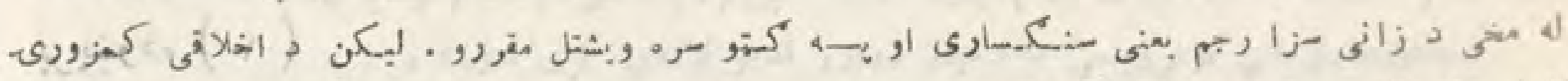

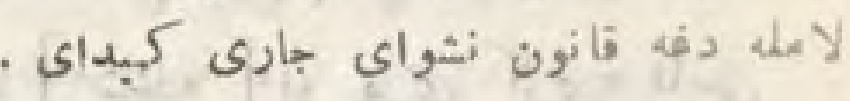

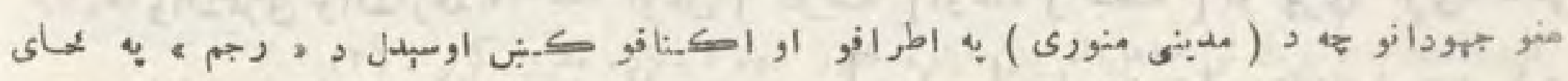

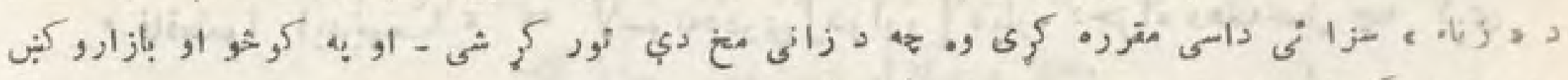

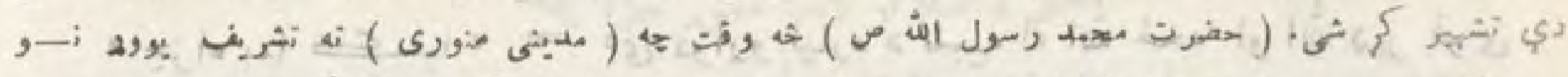

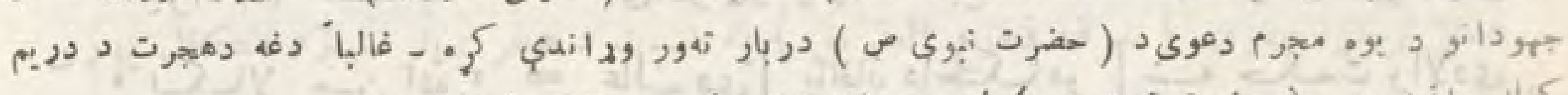

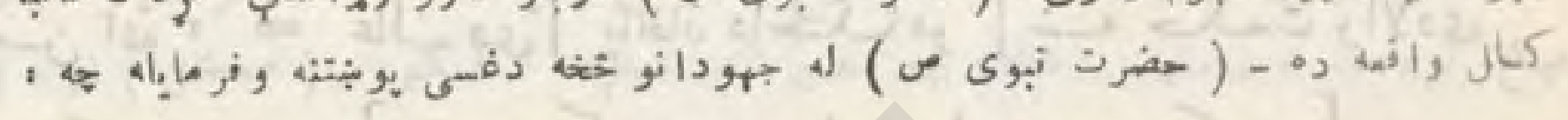

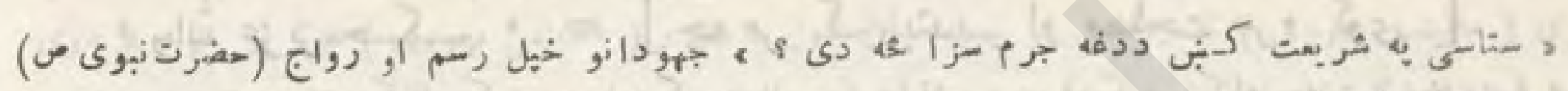

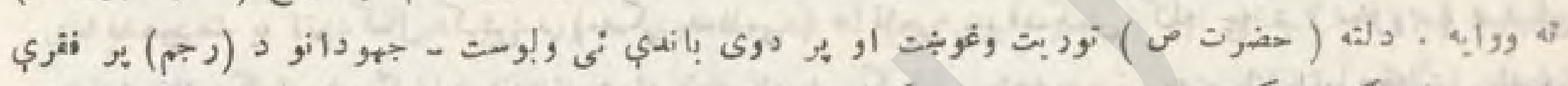

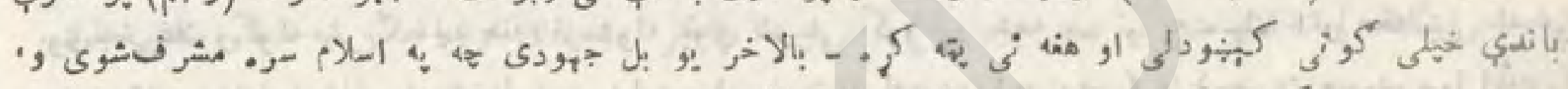

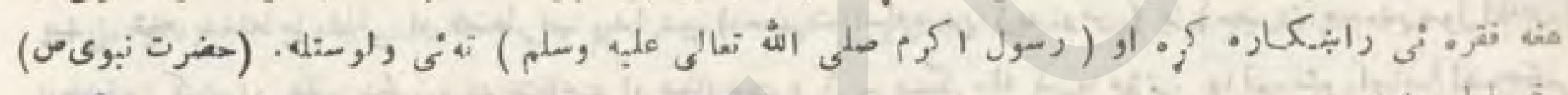
ic -

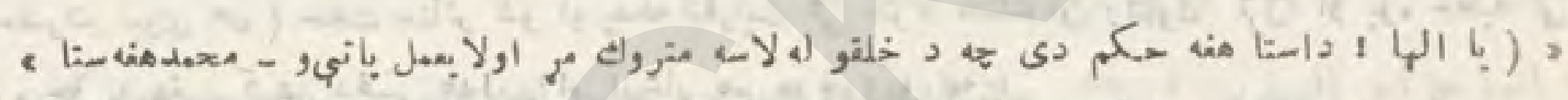

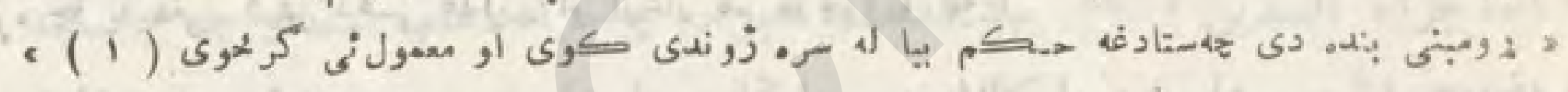

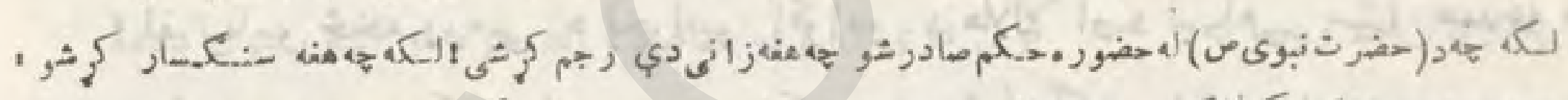

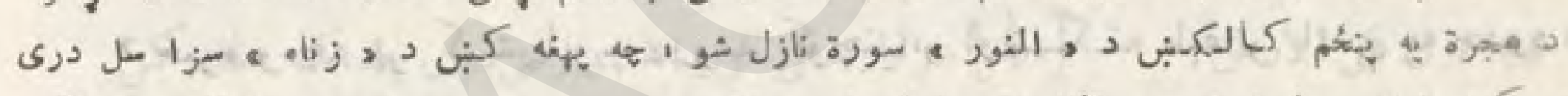

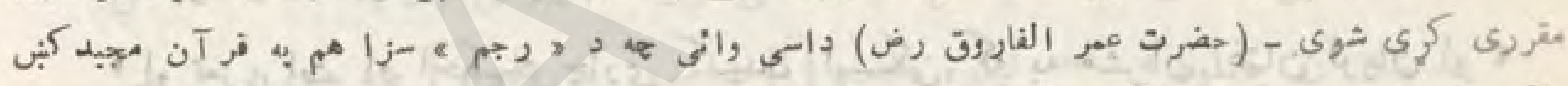

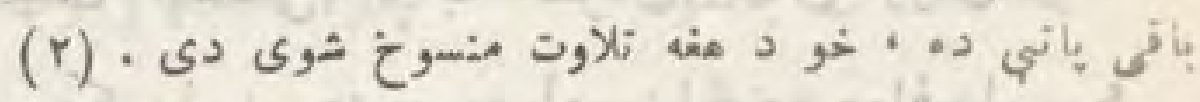

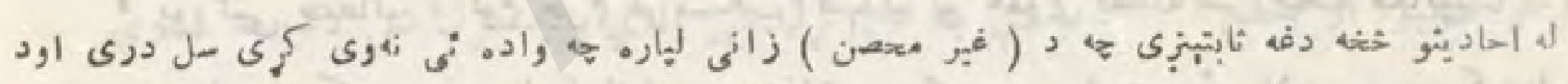

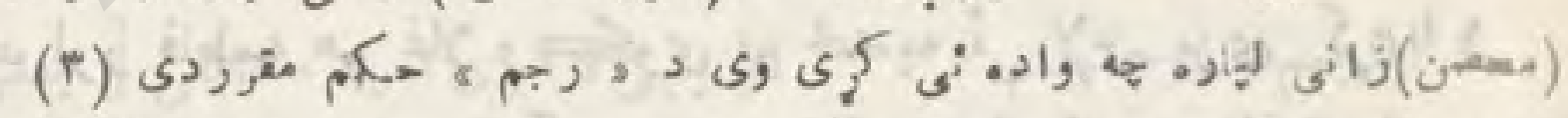

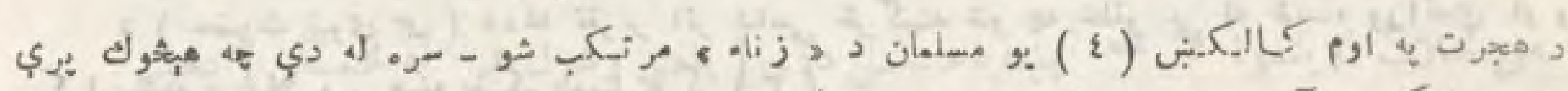

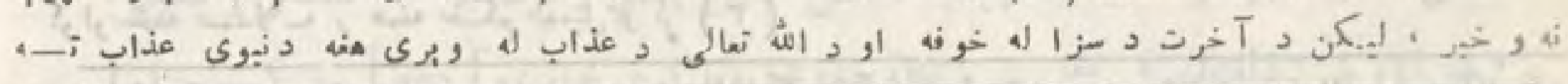

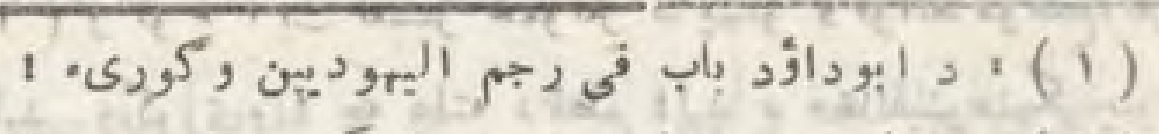

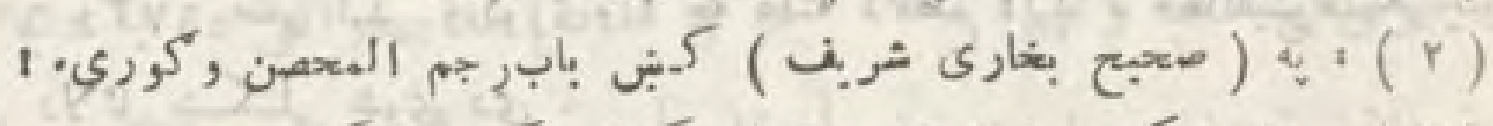

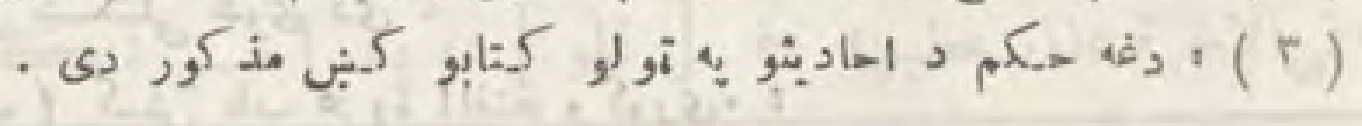

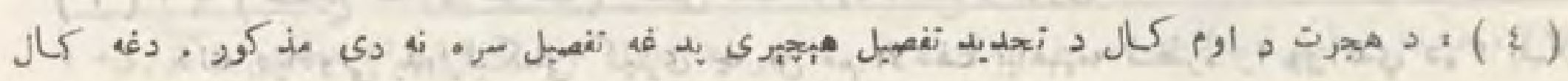

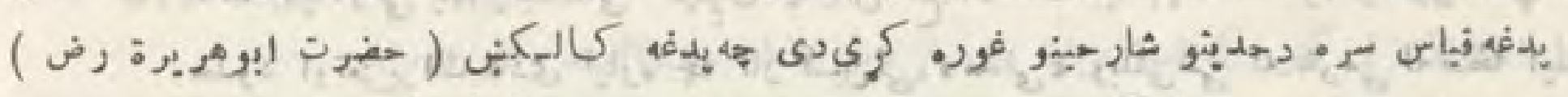

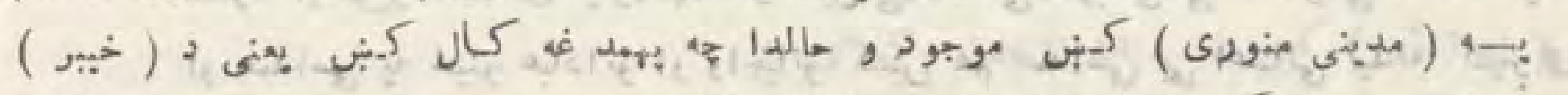

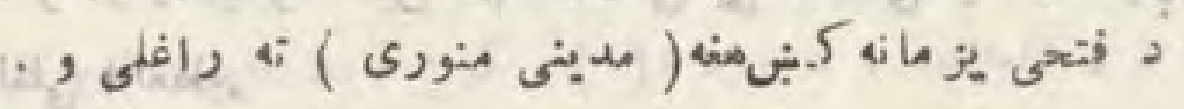




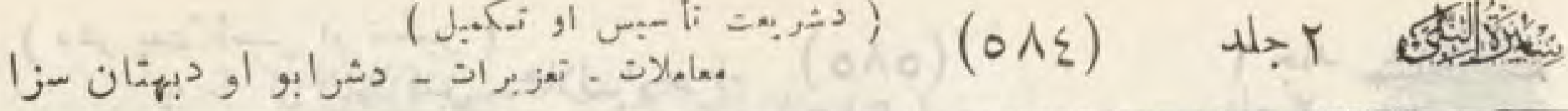

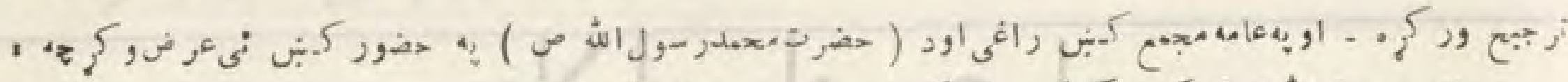

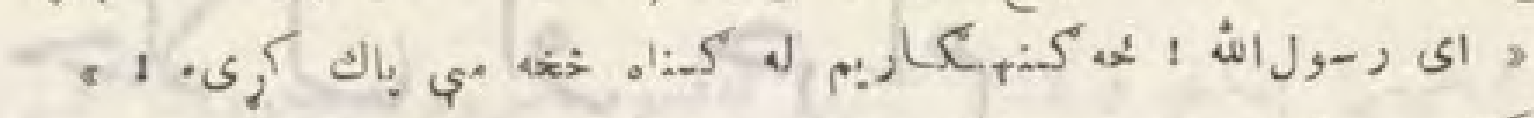

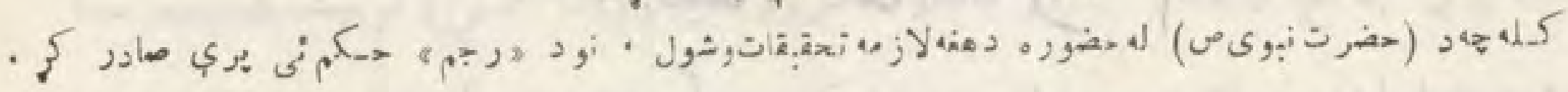

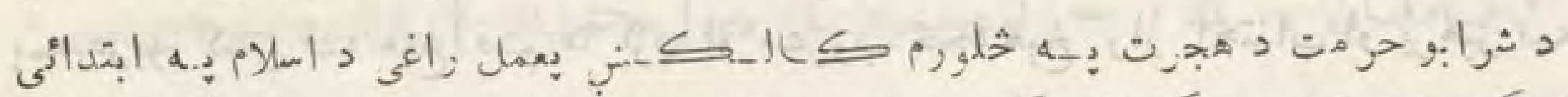

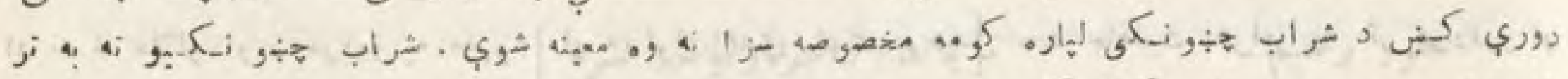

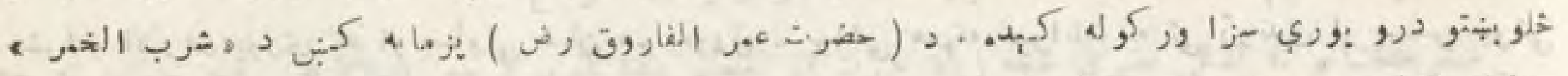
(1) (1) -

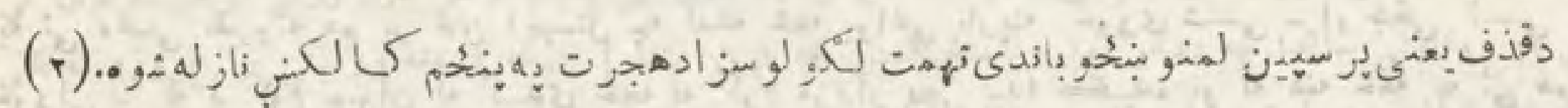

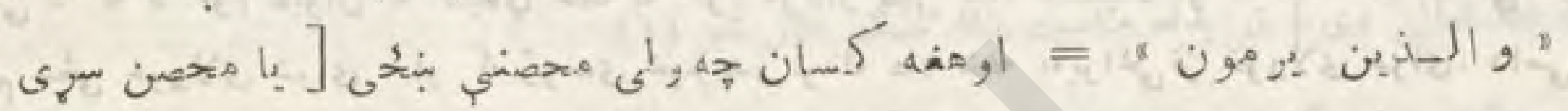

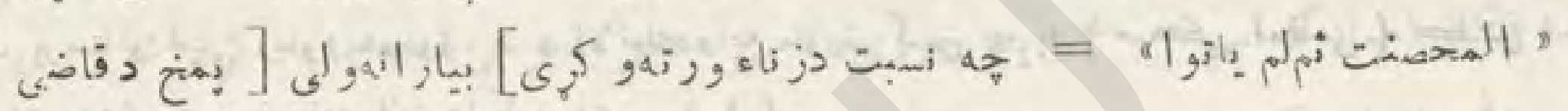

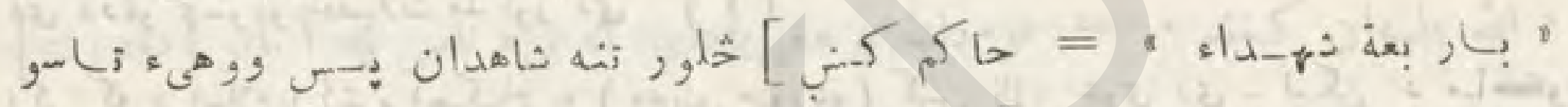

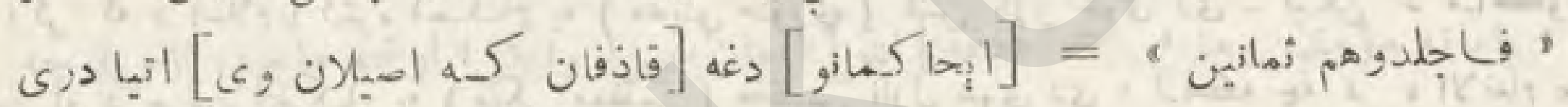

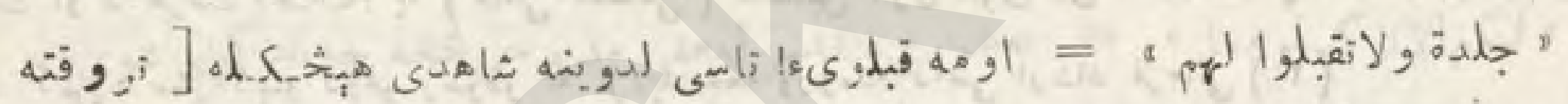

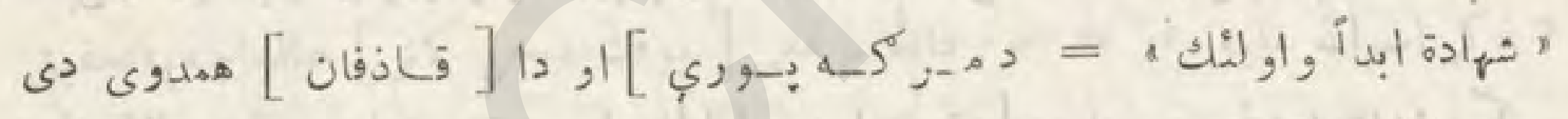

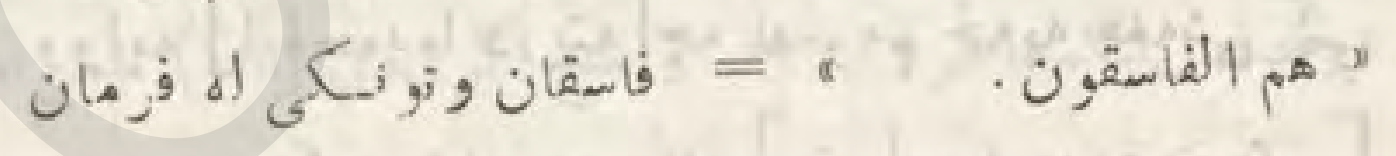

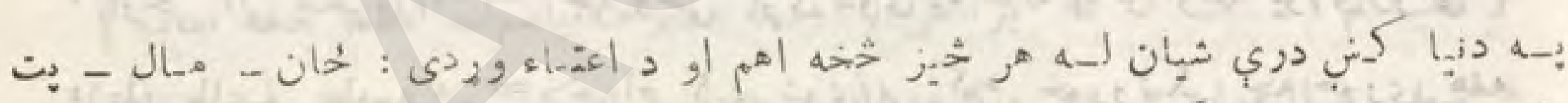

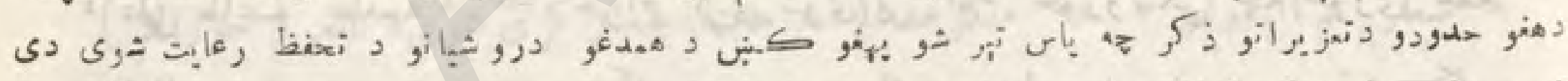

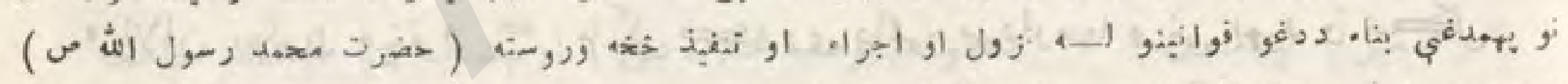

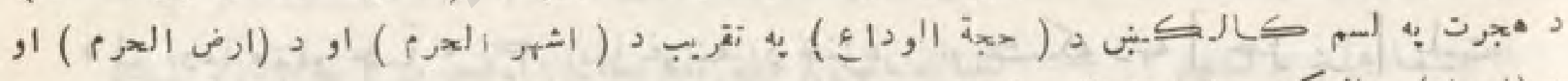

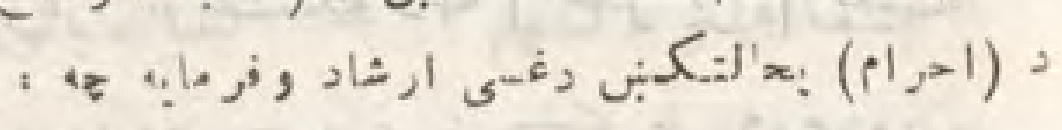

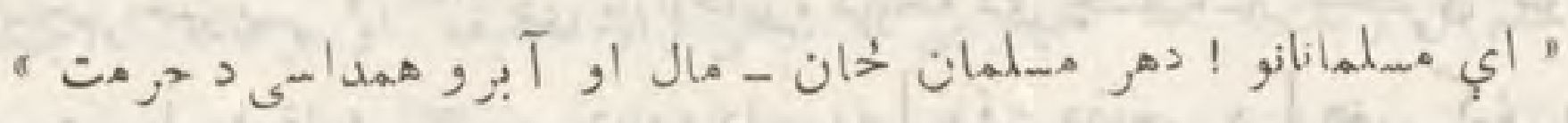

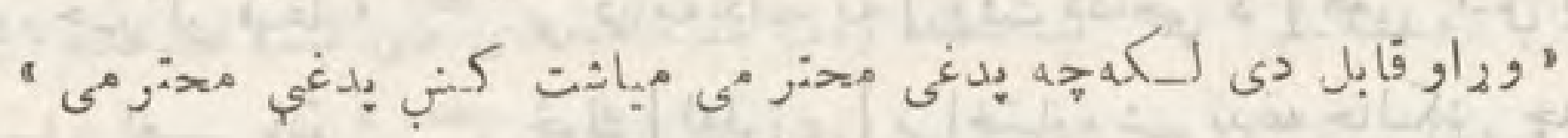

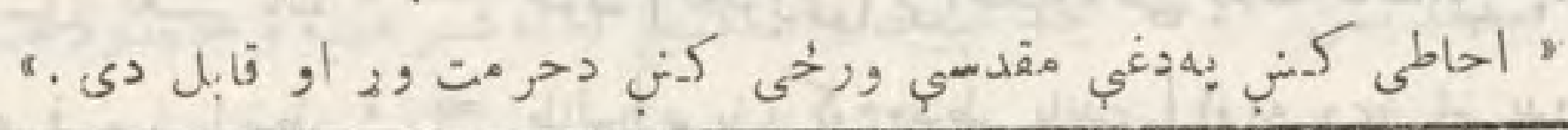

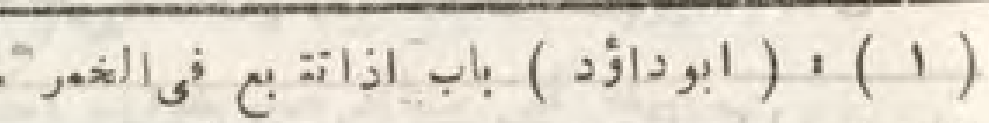

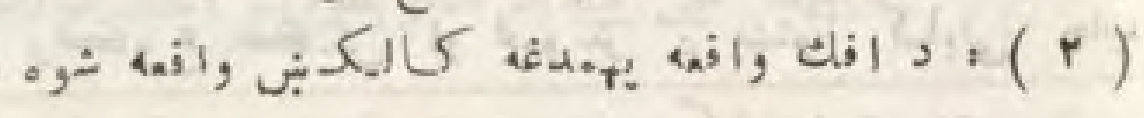

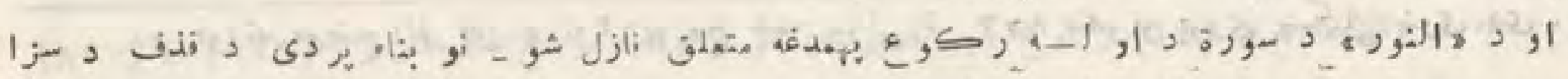

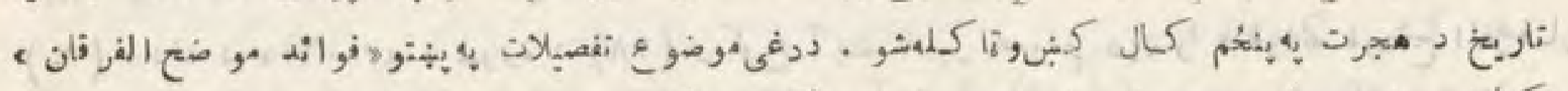
كابلى 


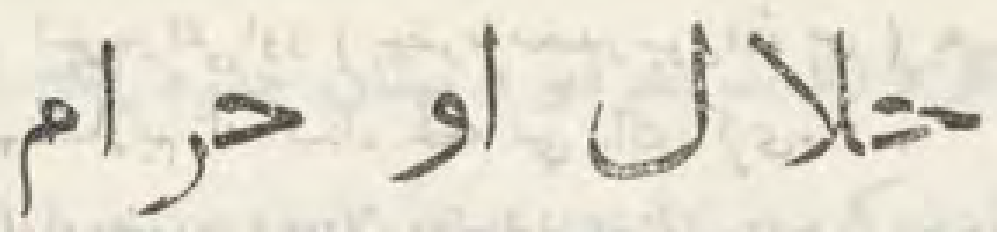

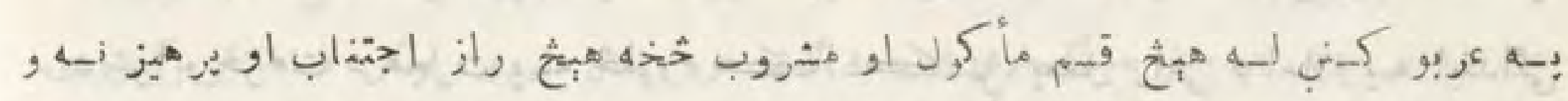

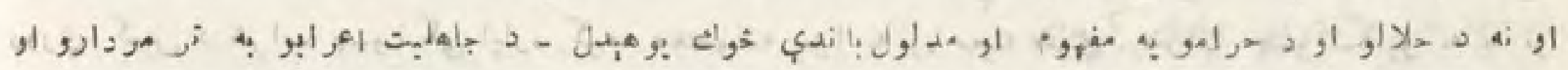

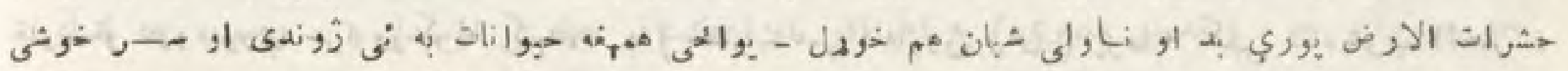

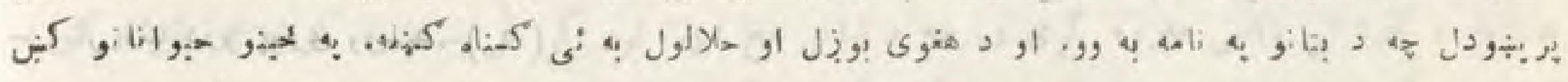

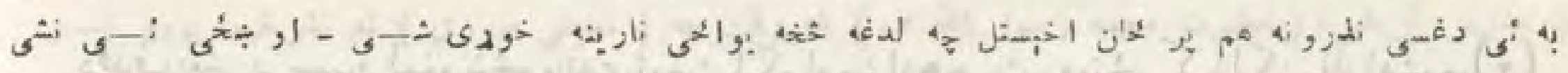

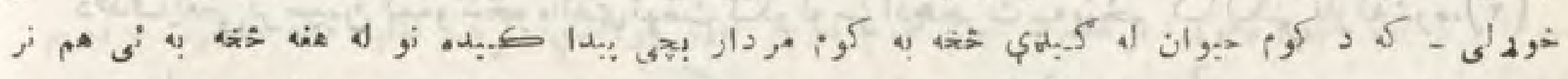

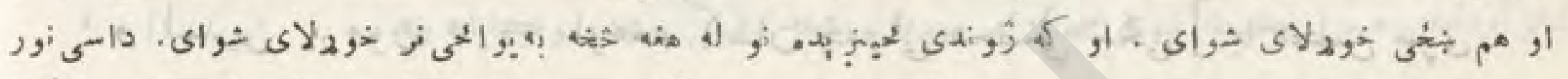

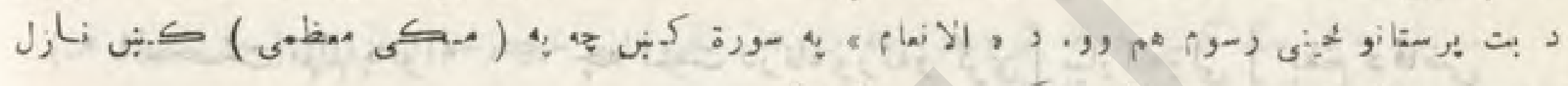

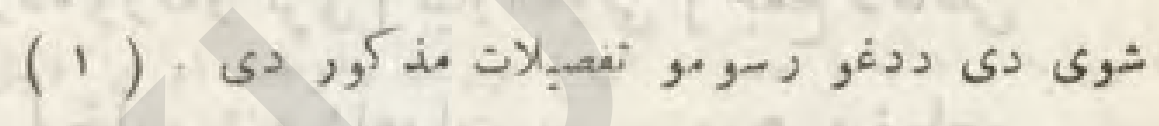
اكر ك of

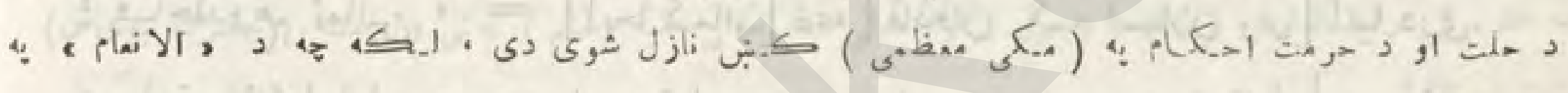

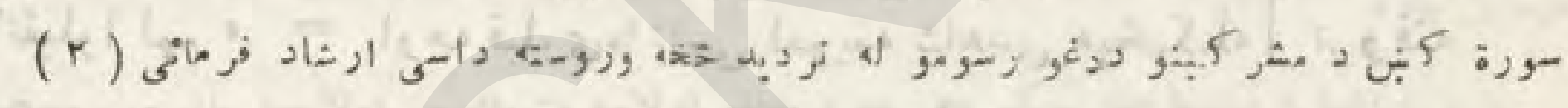

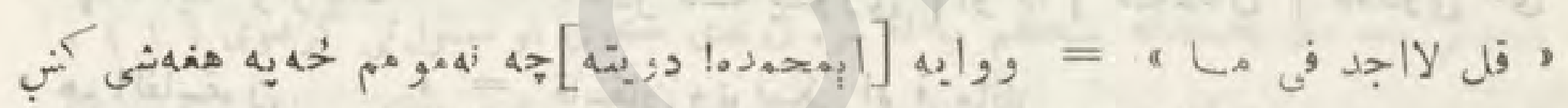

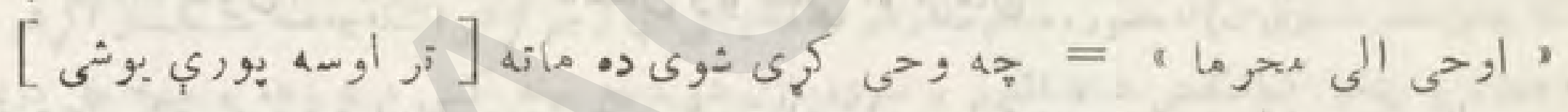

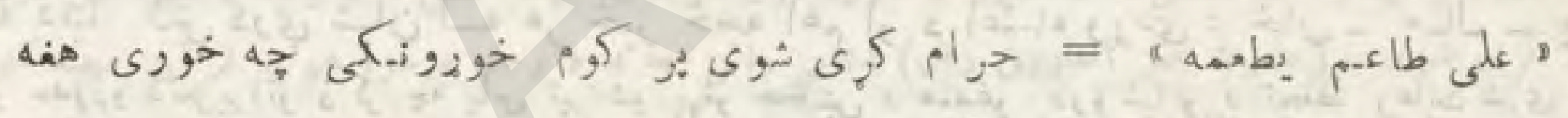

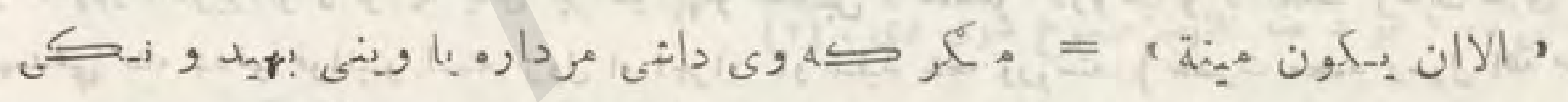

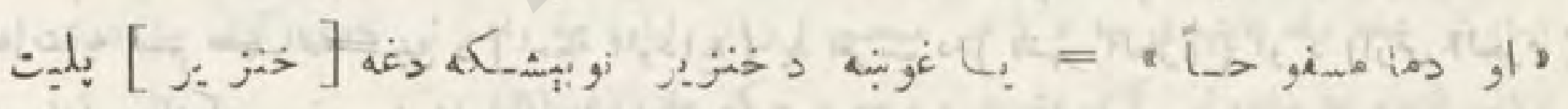

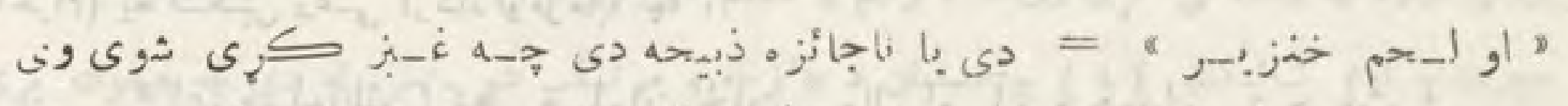

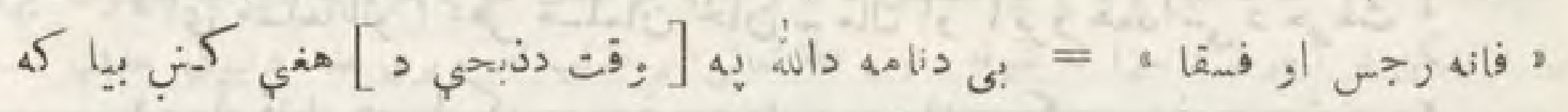

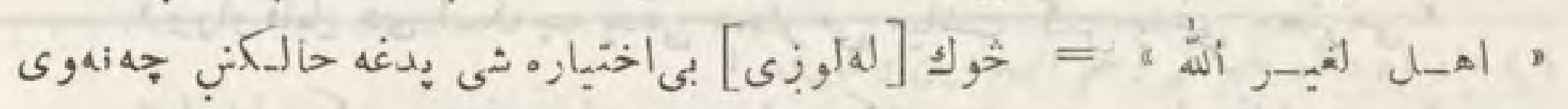

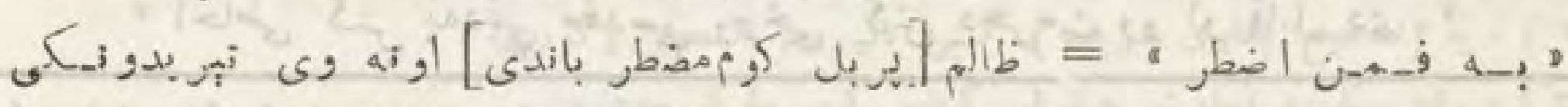

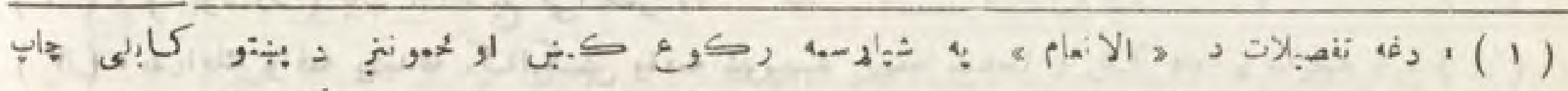
.

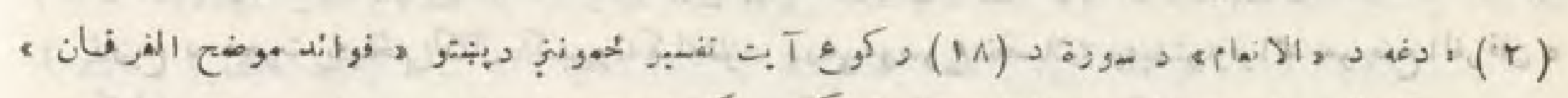
1. $1.5,5$, 


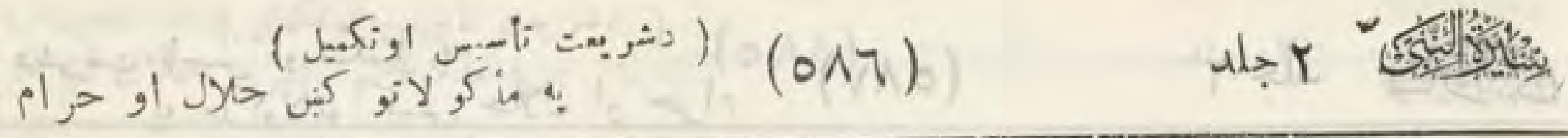

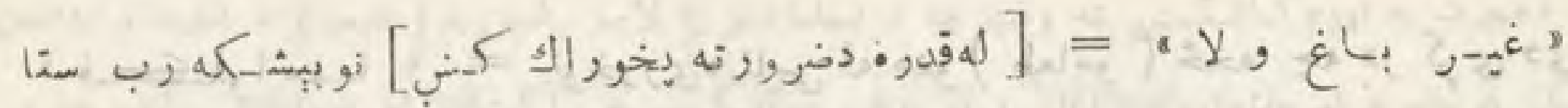

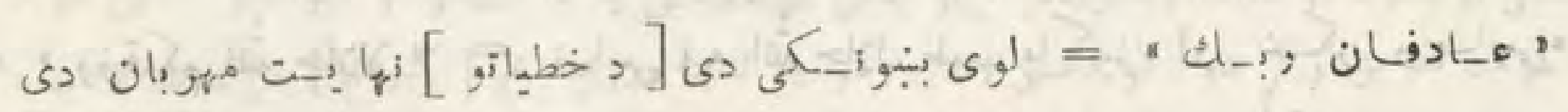

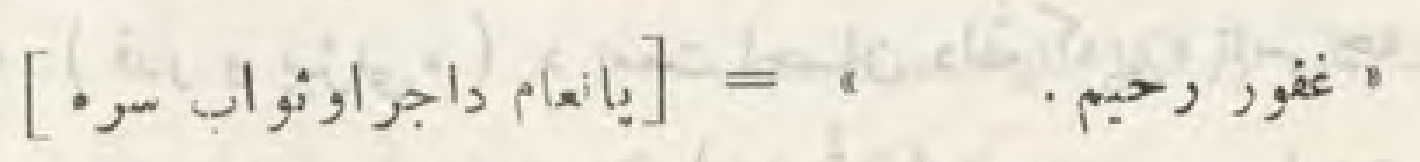

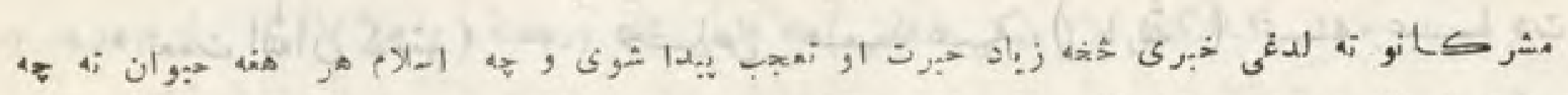

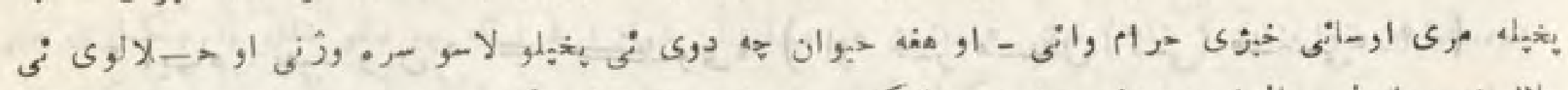

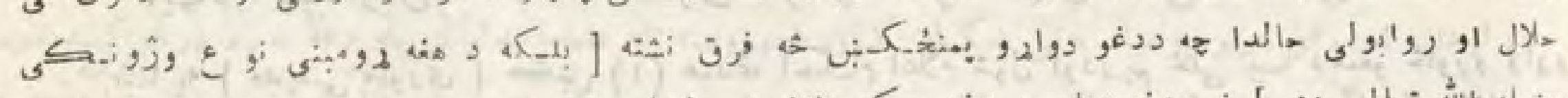

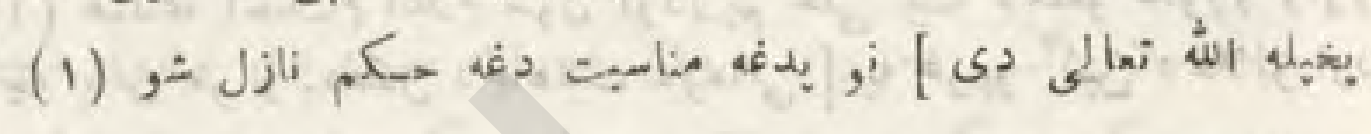

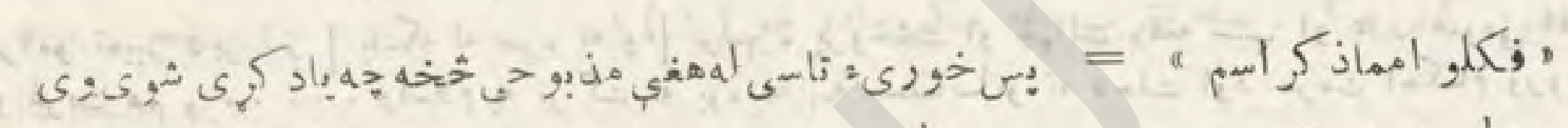

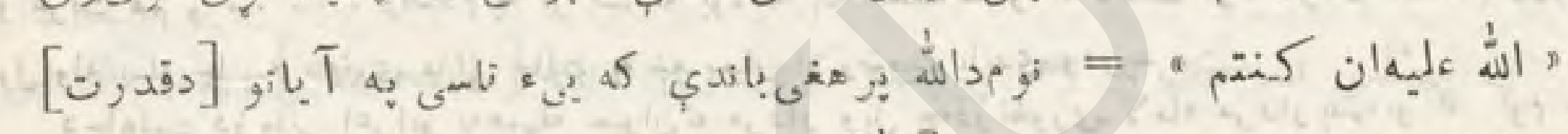

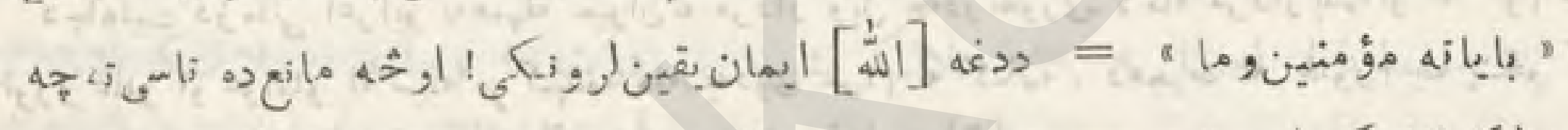

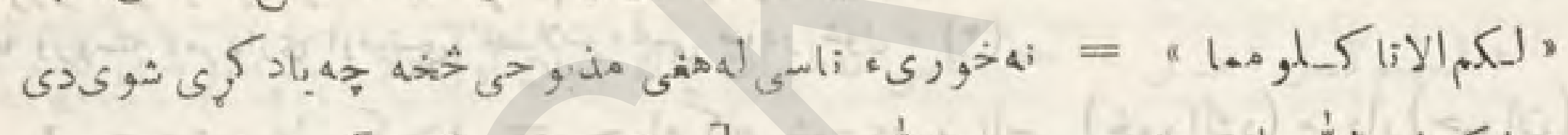

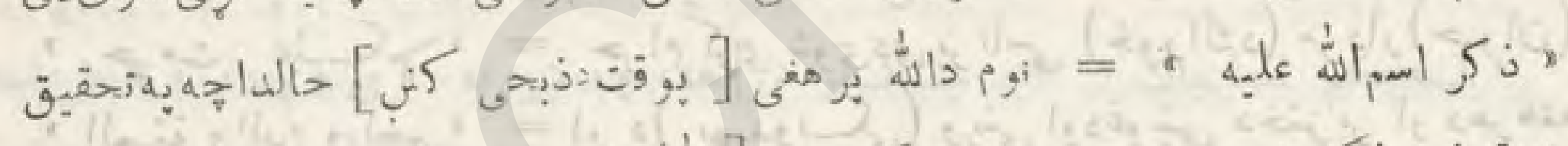

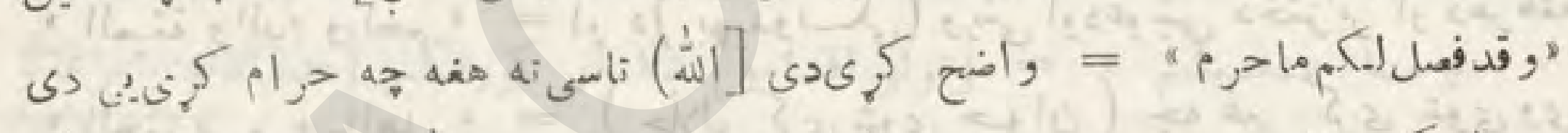

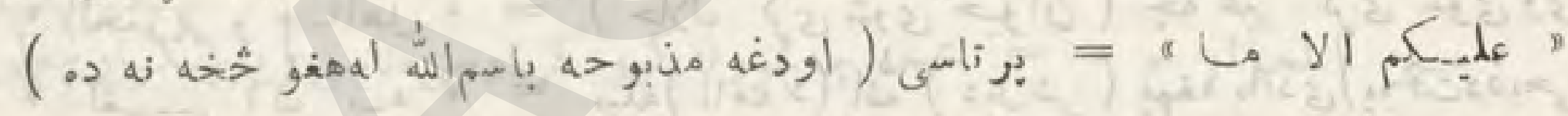

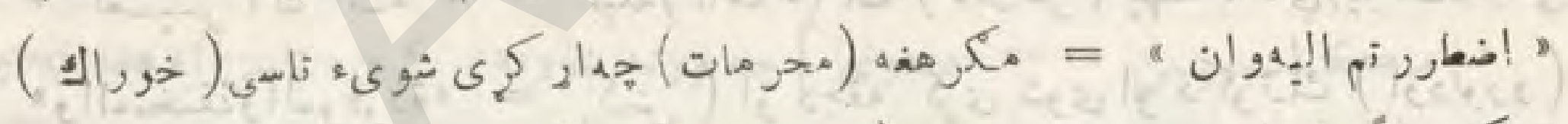

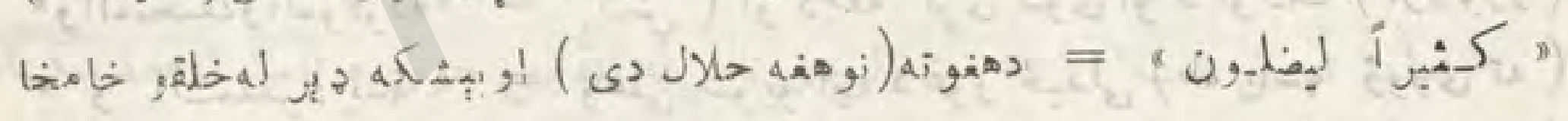

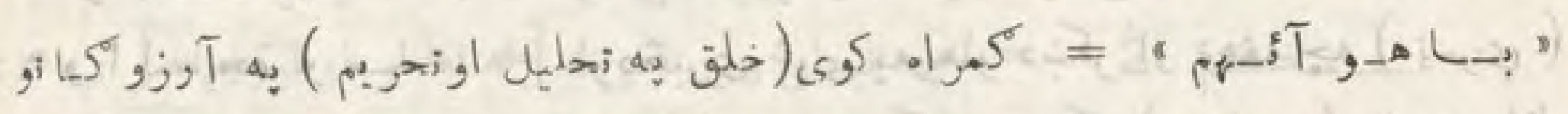

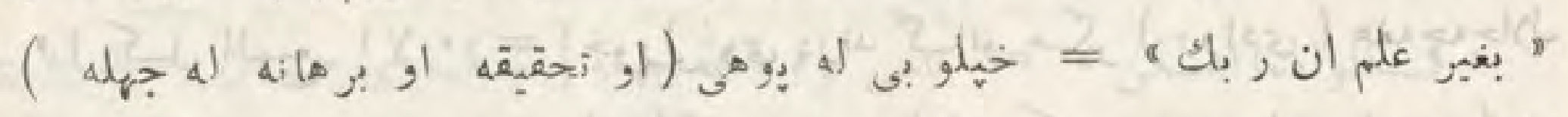

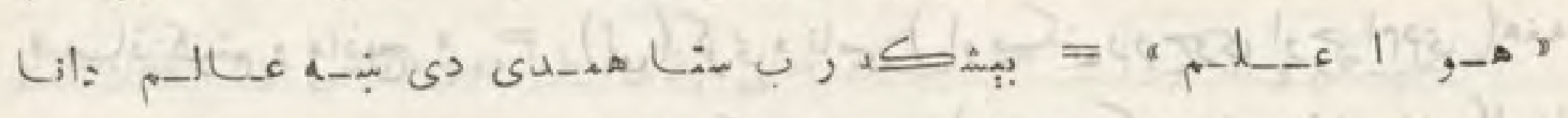

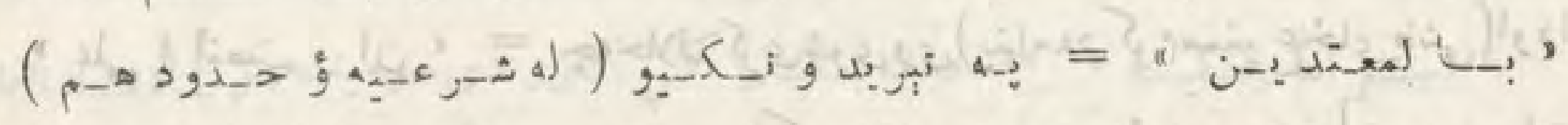
ه ه

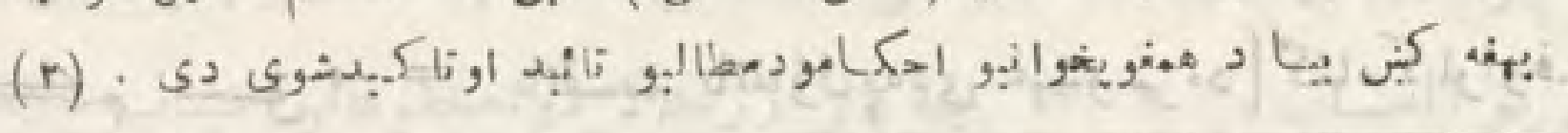

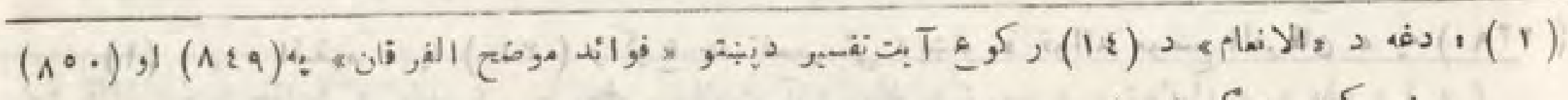

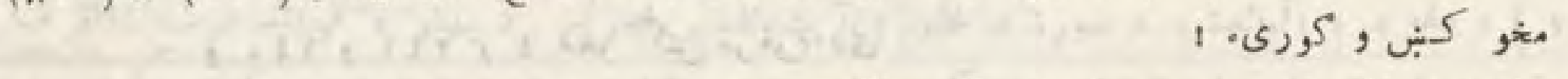

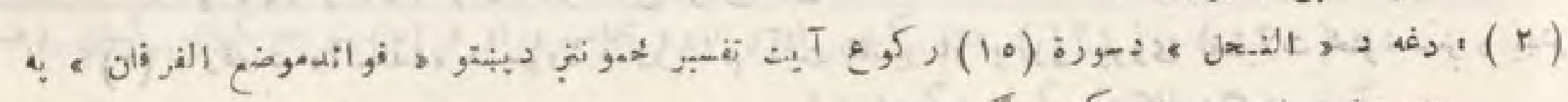

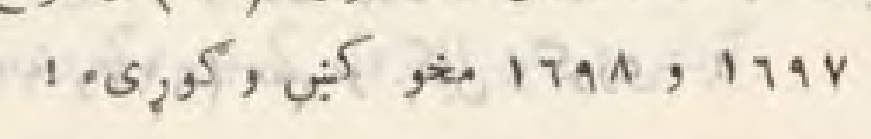


踦)

" ف.

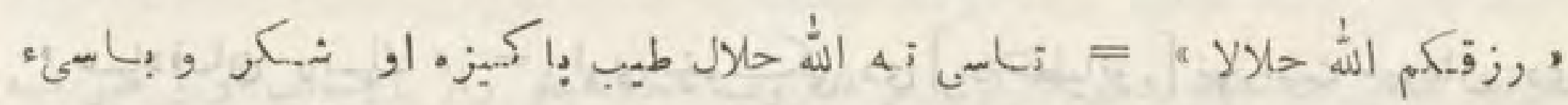

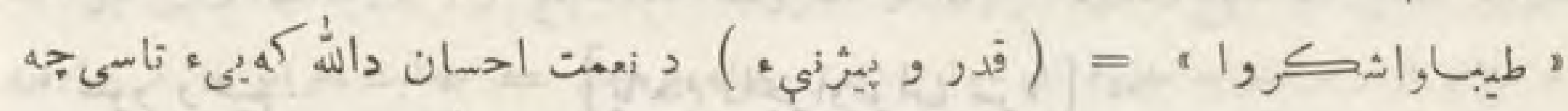

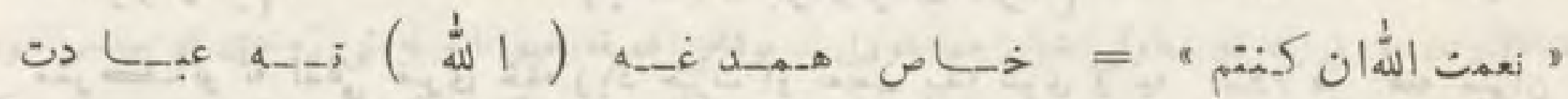

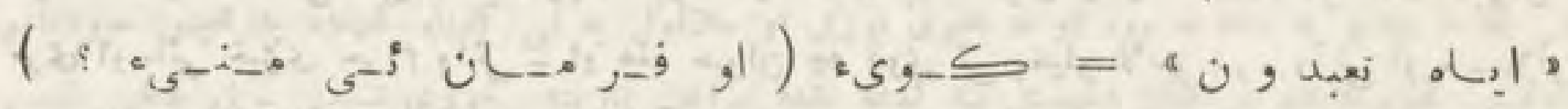

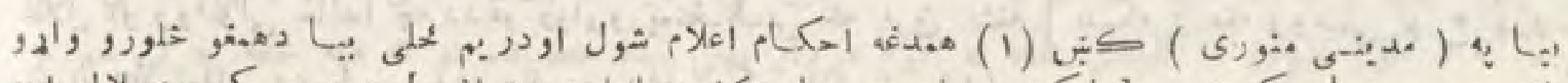

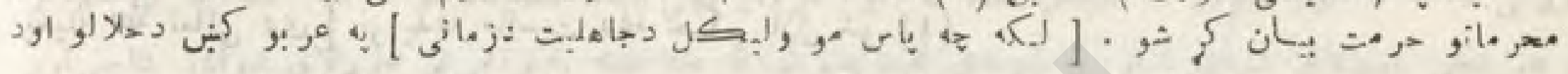

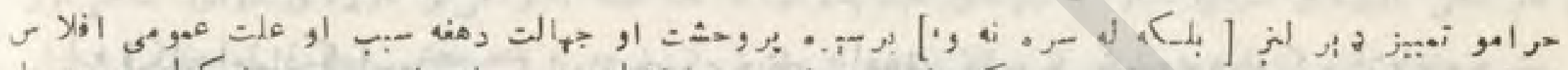

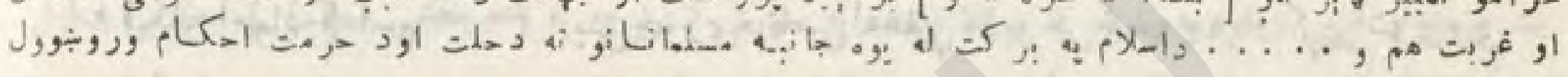

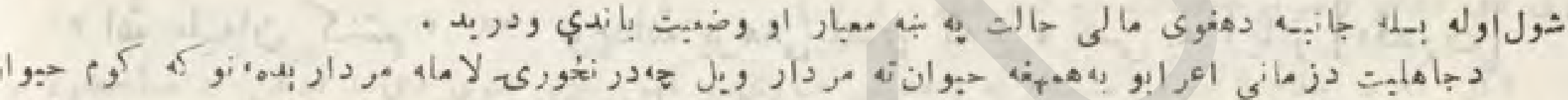

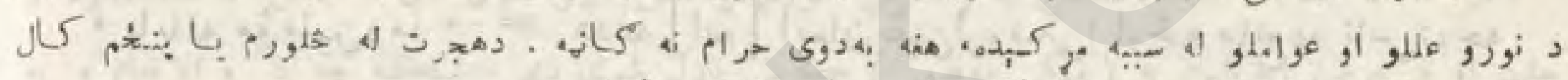

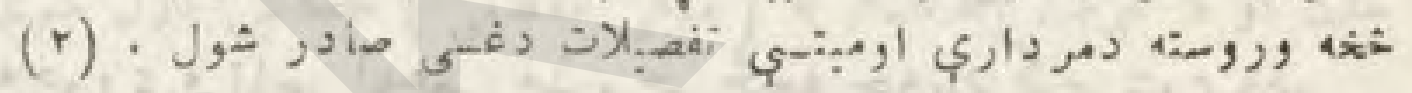

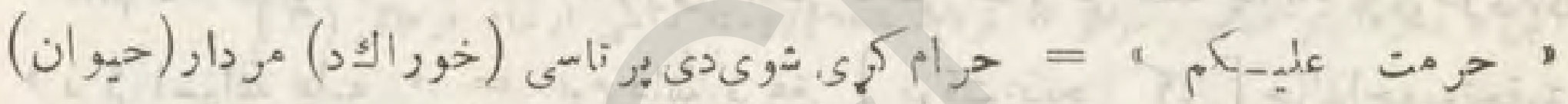

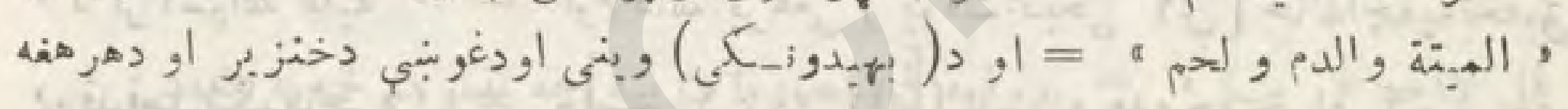

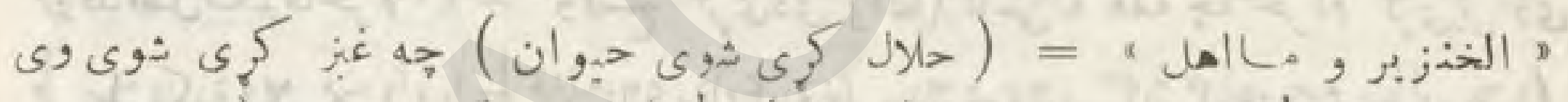

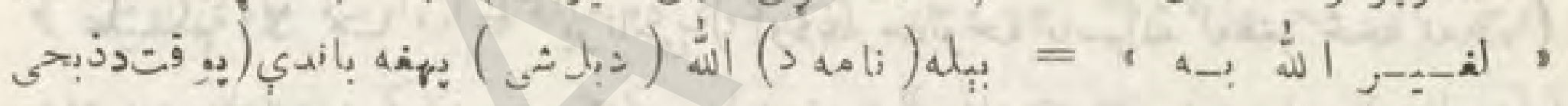

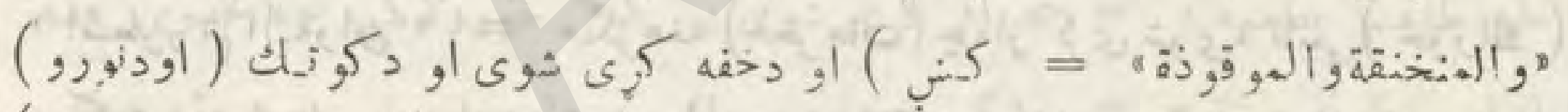

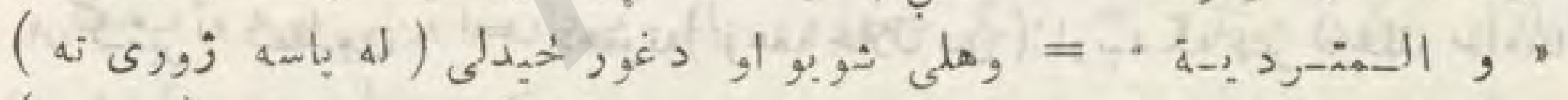

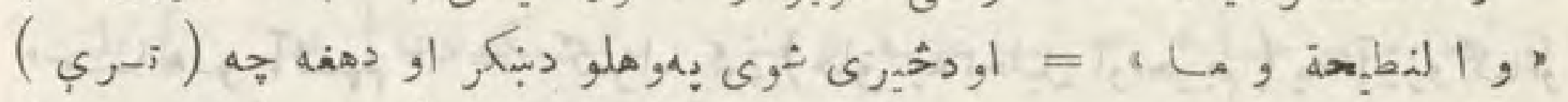

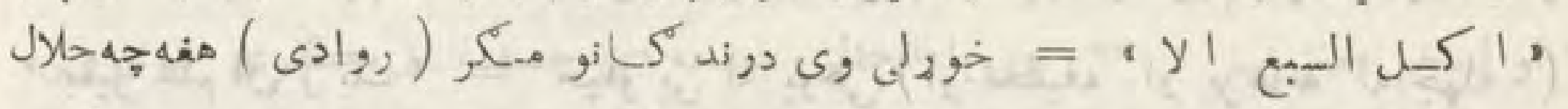

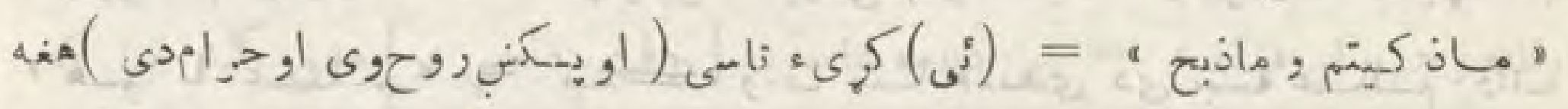

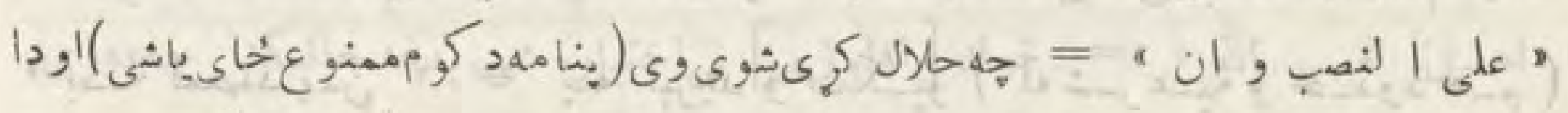

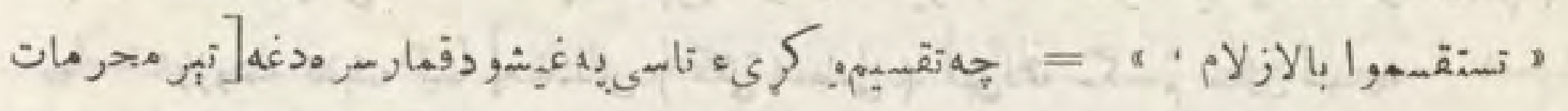

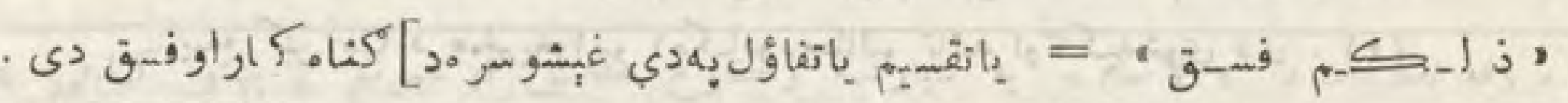

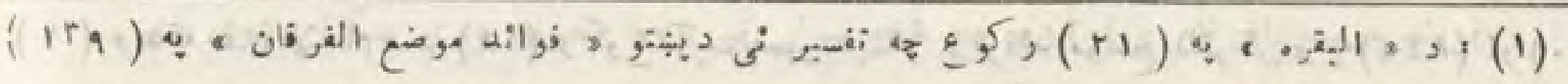
ى

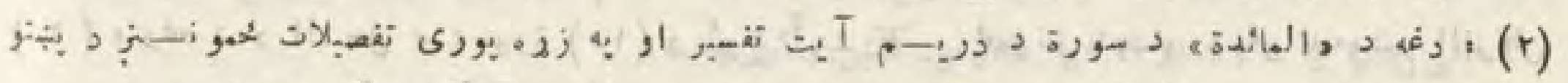

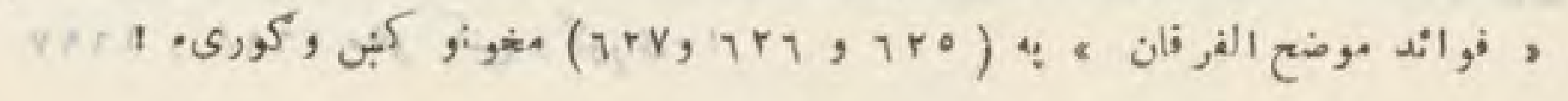




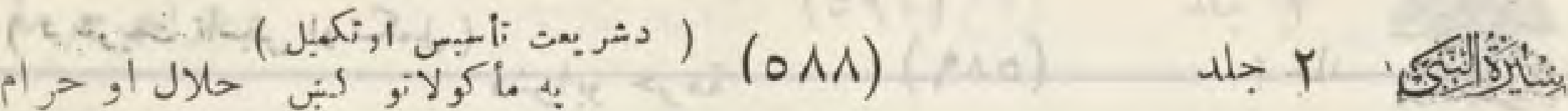

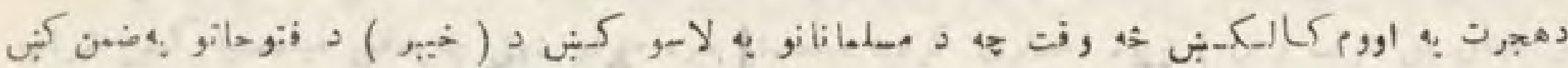

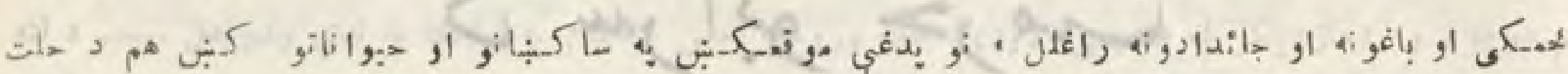

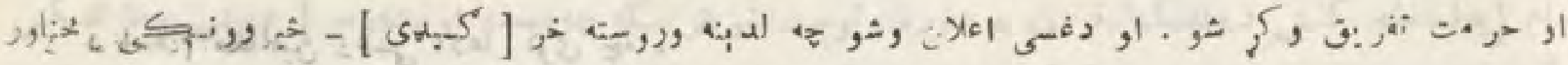

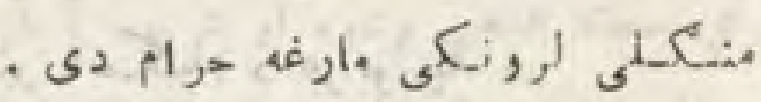

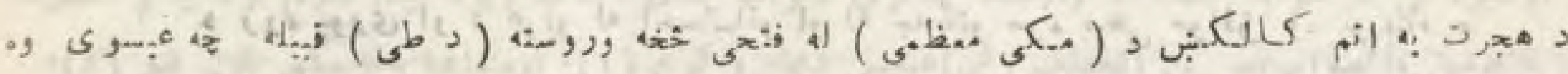

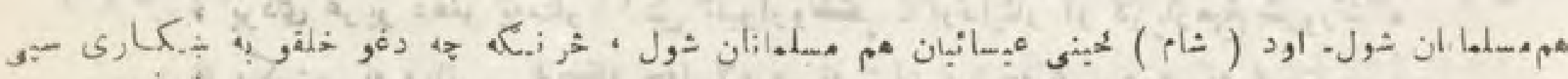

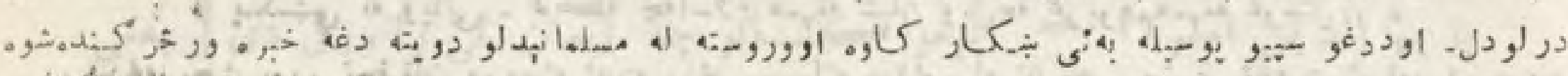

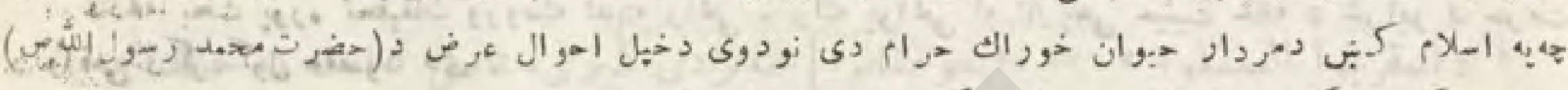

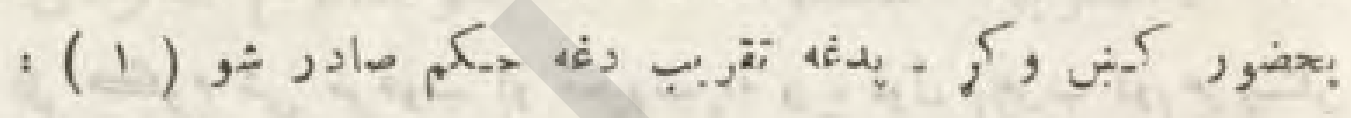

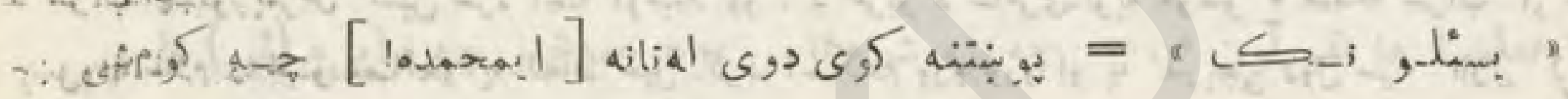

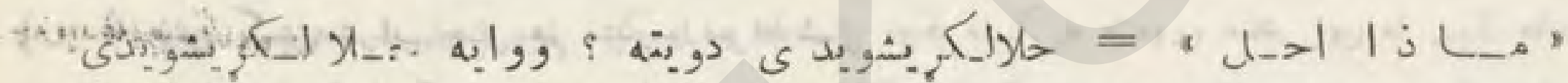

A

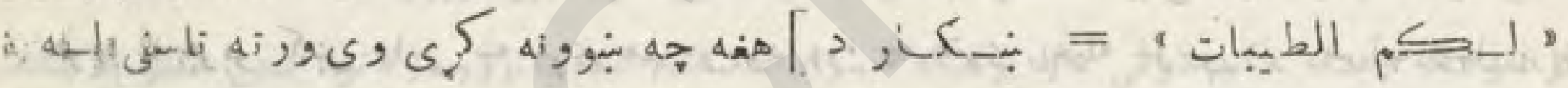

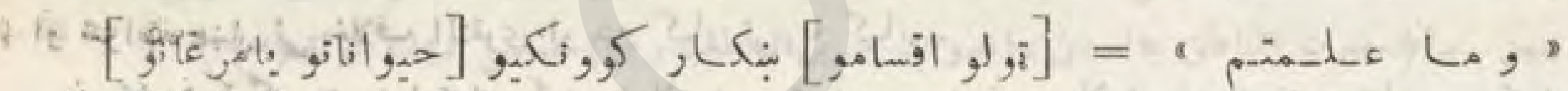

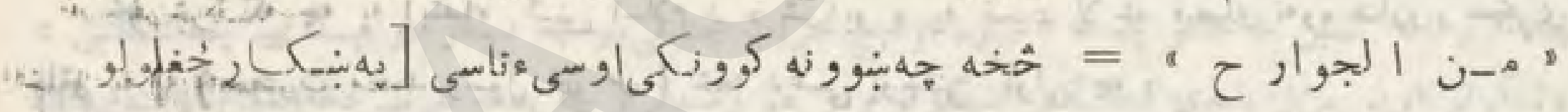
"ه

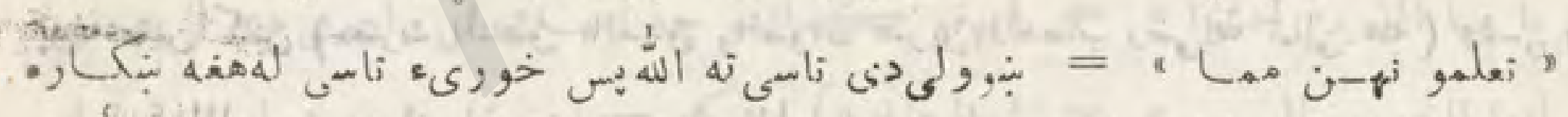

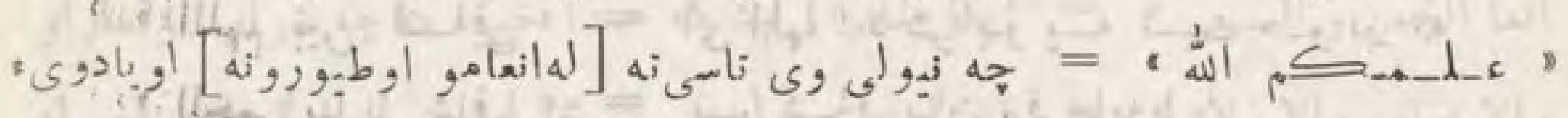

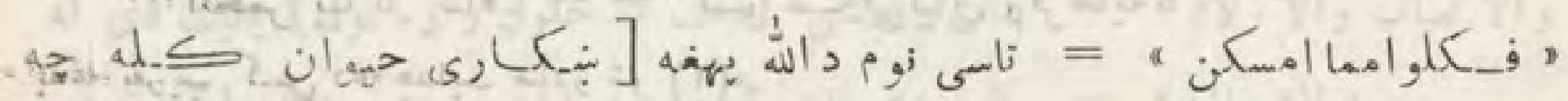

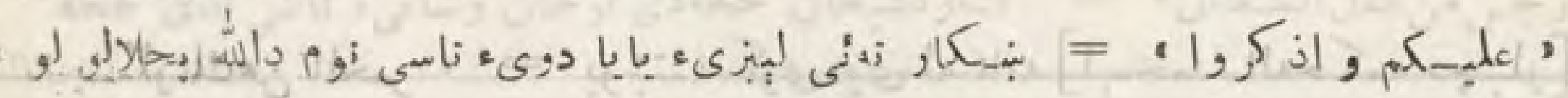

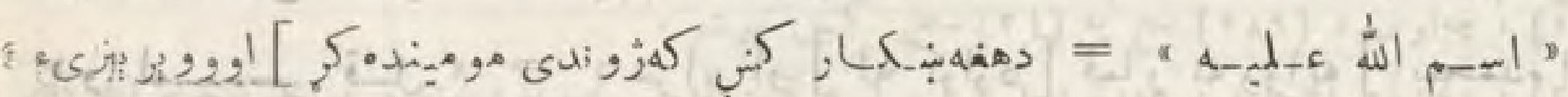

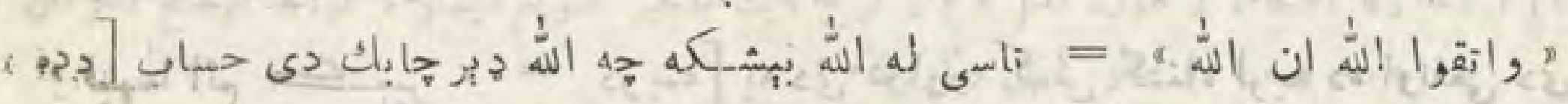

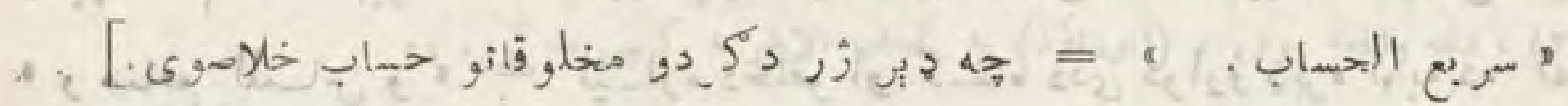

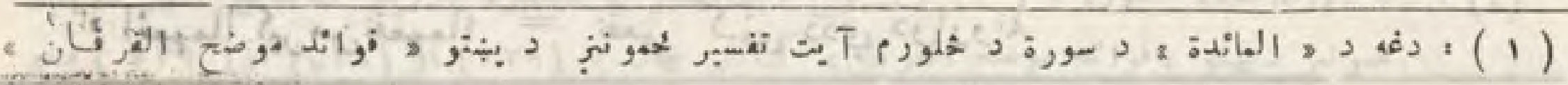

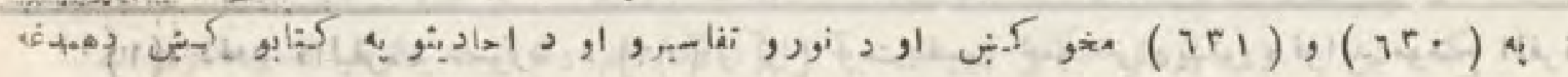
آ 


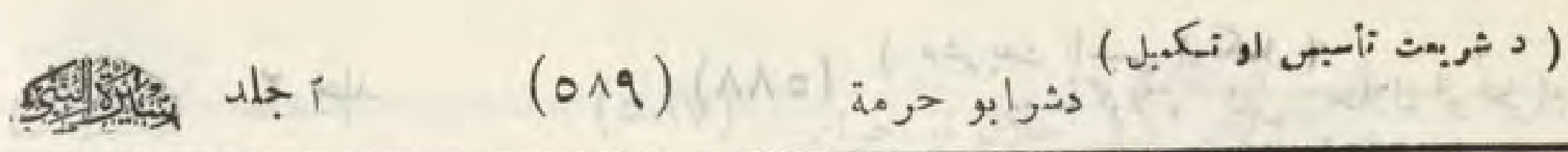

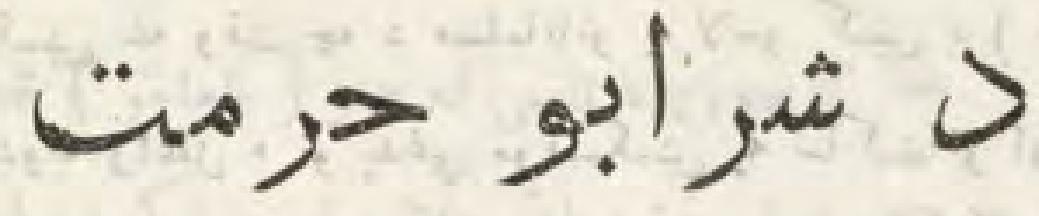

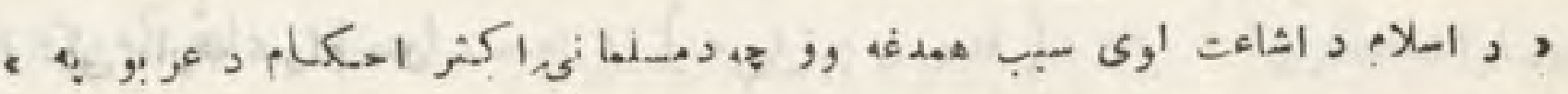

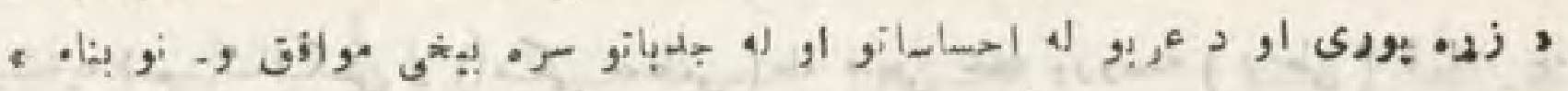

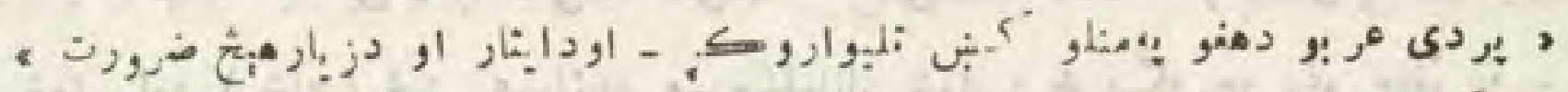

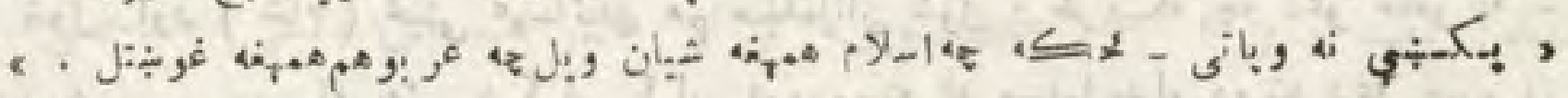

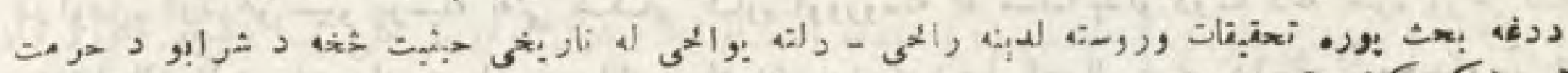

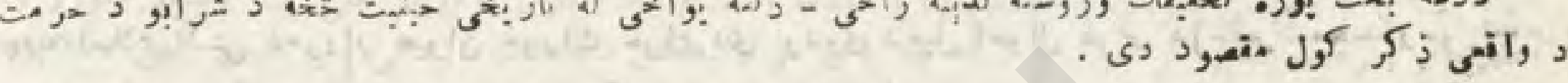

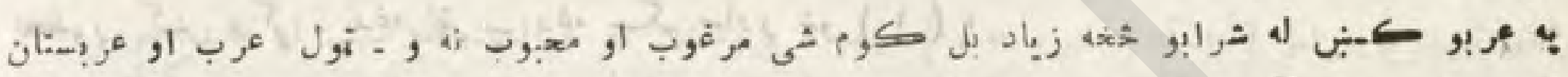

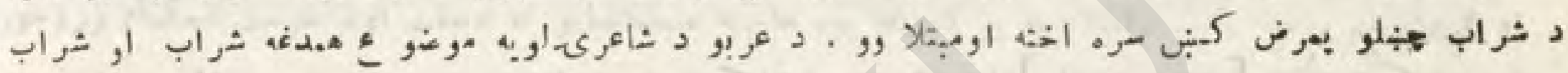

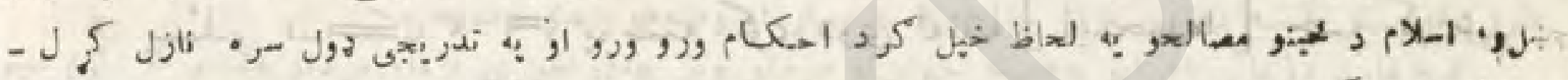

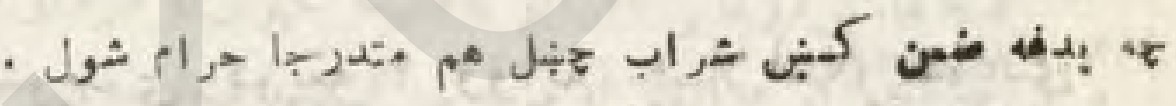

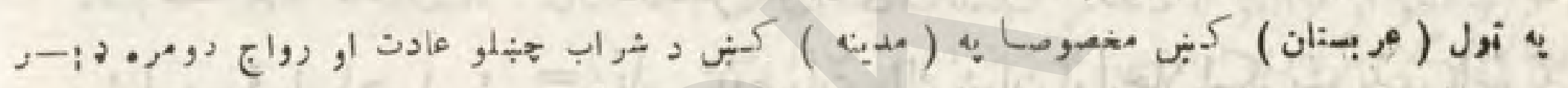

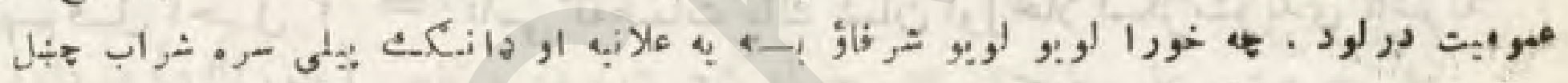

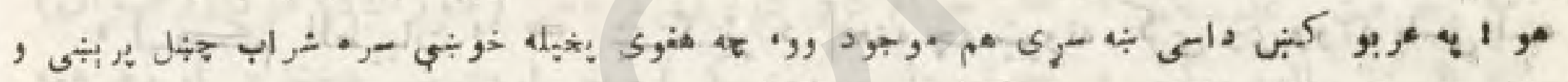

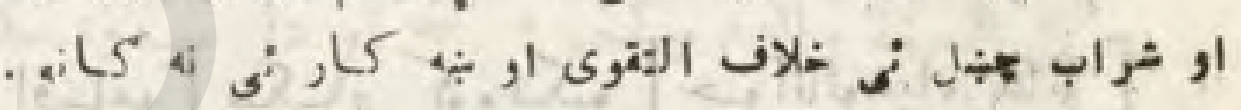

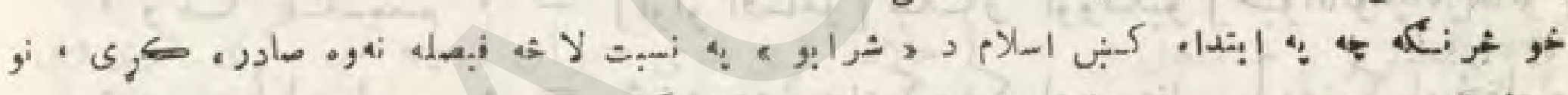

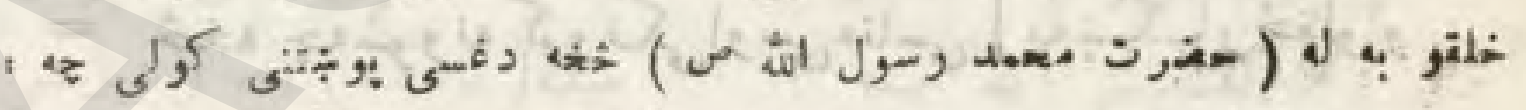

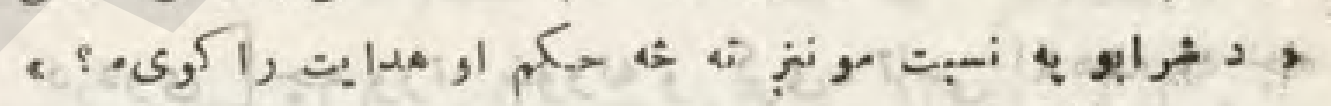

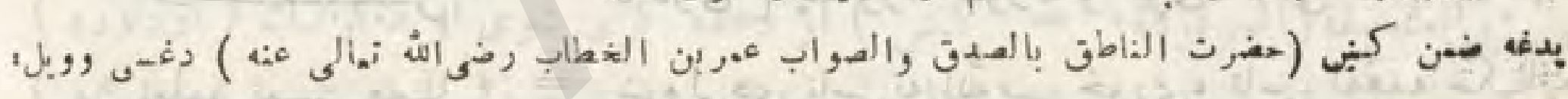

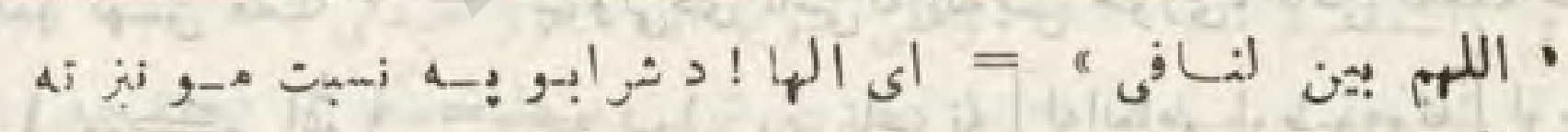

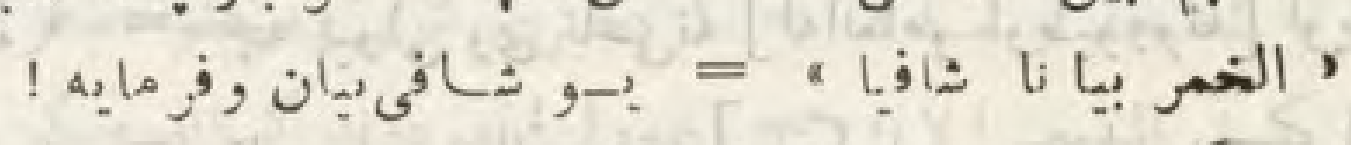

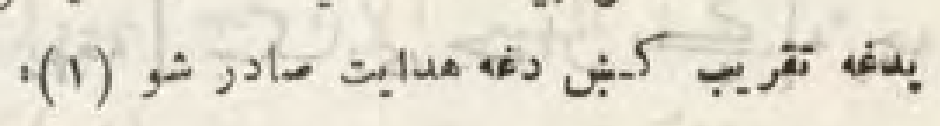

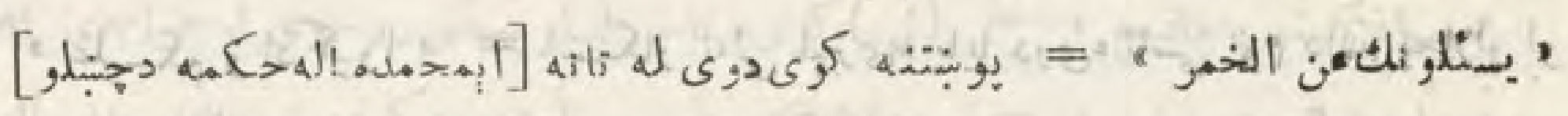

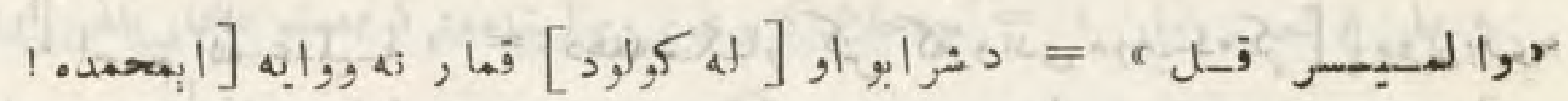

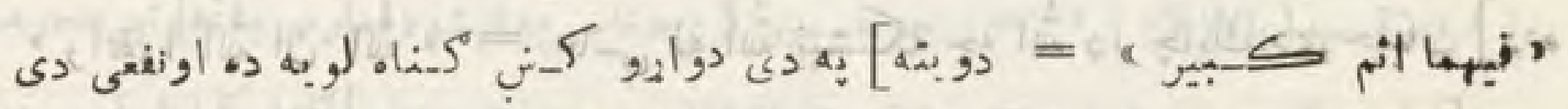

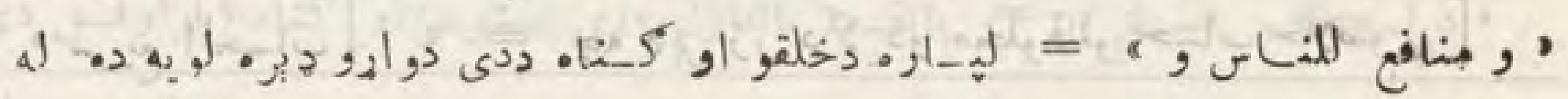

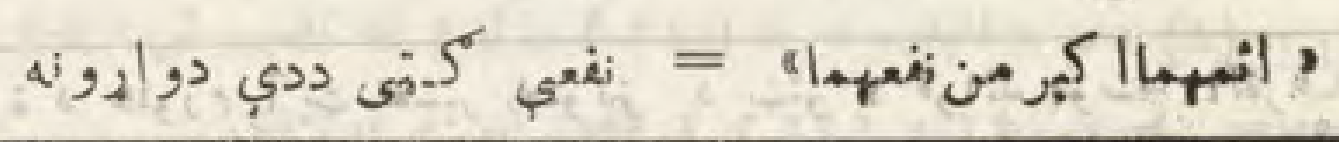

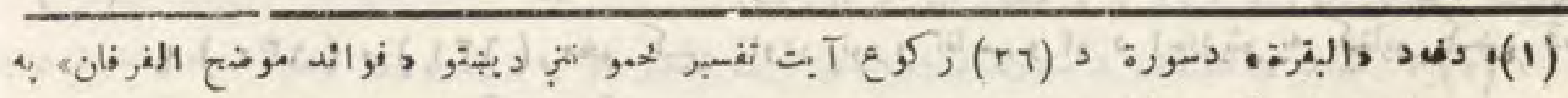
1. (199, 191) 


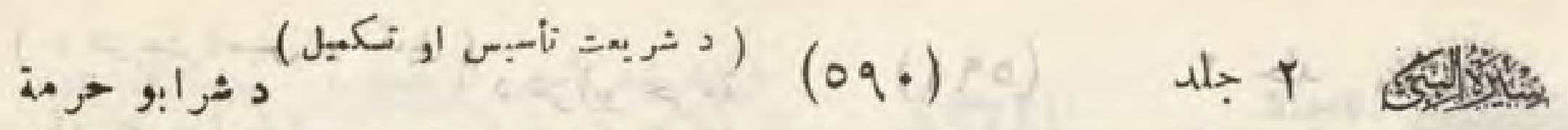

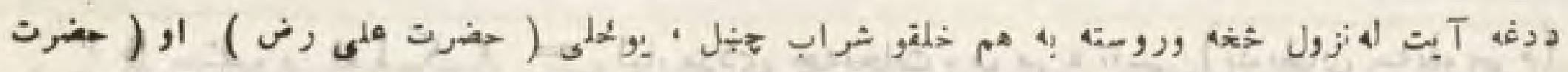

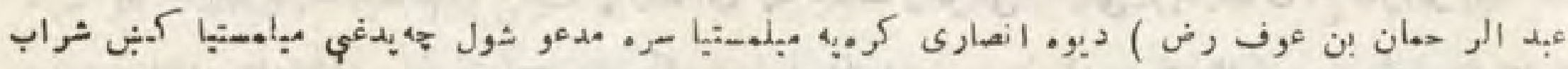

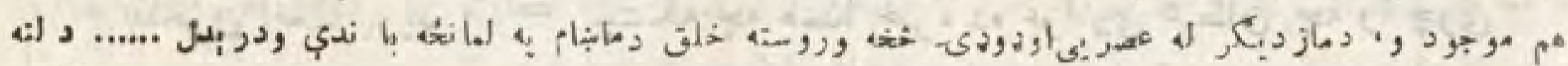

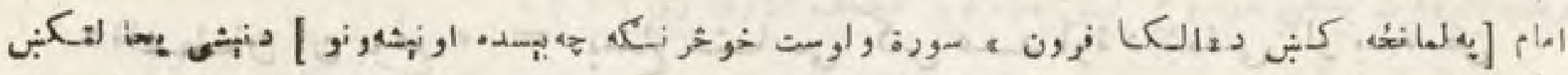

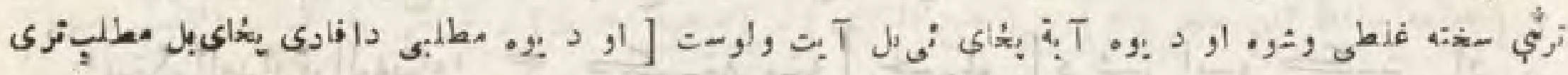

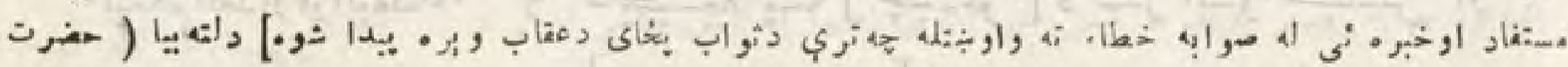

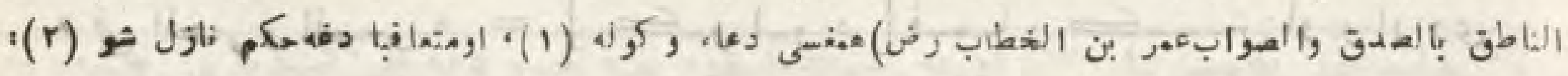

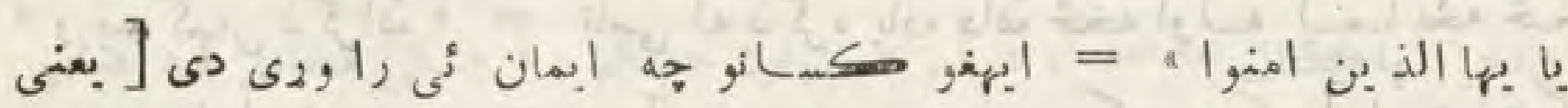

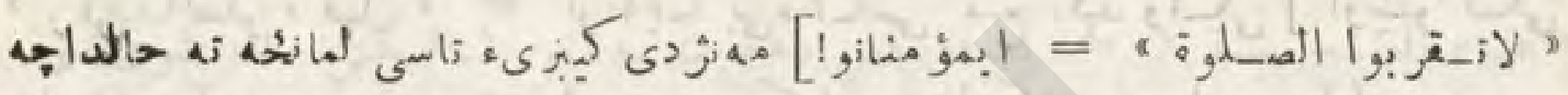

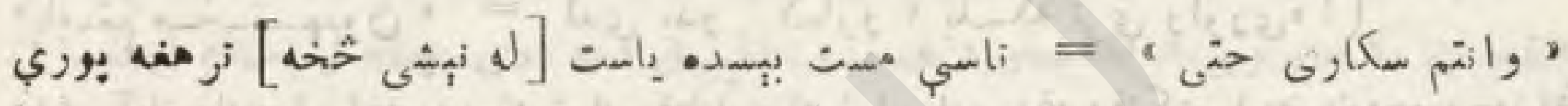

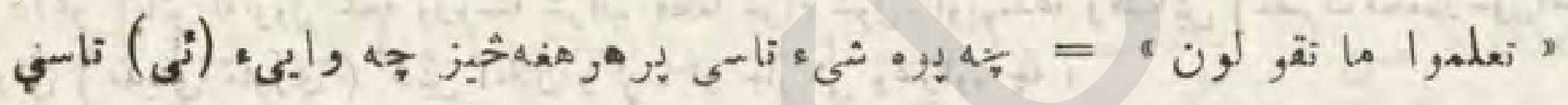

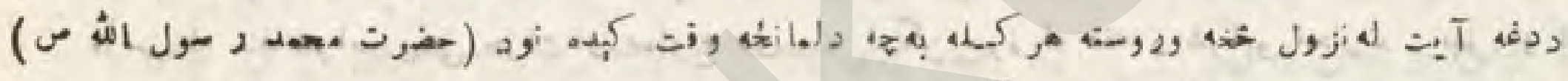

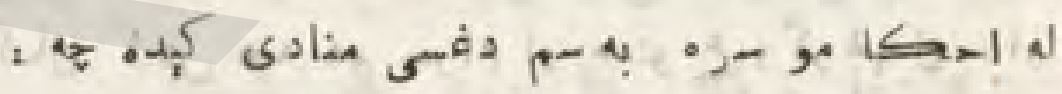

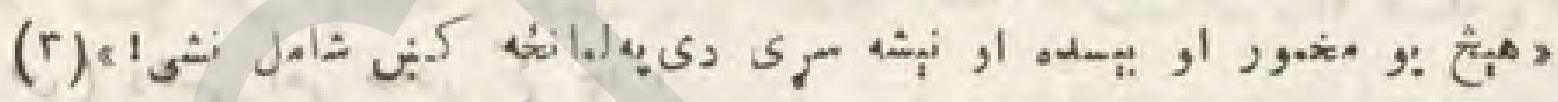

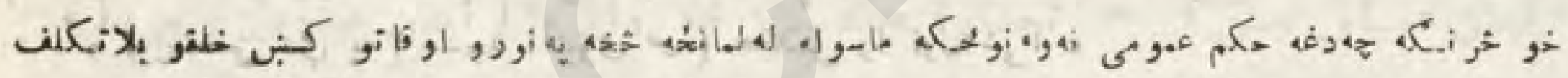

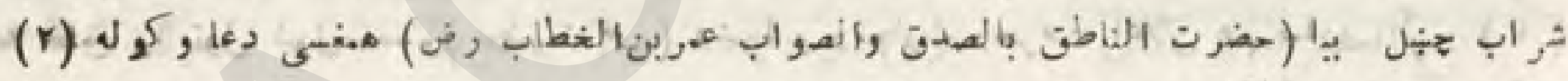

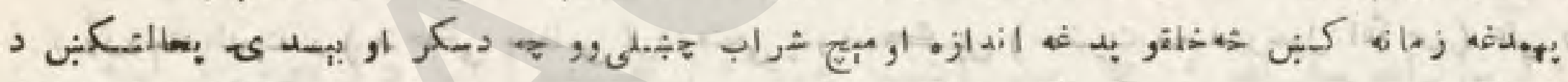

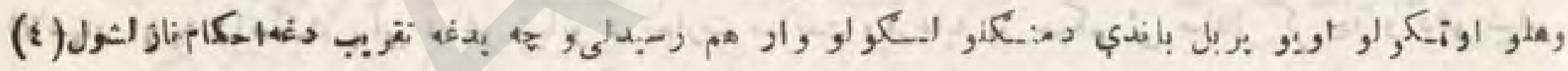

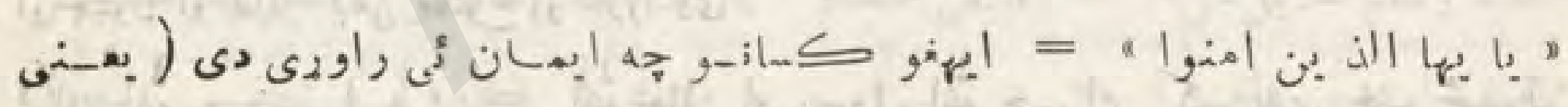

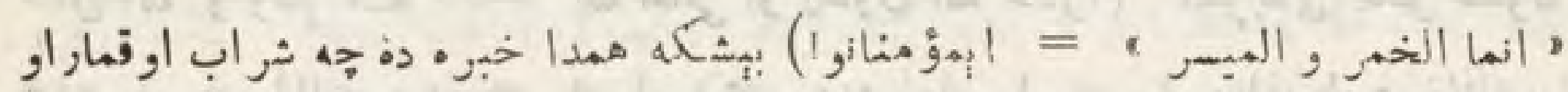

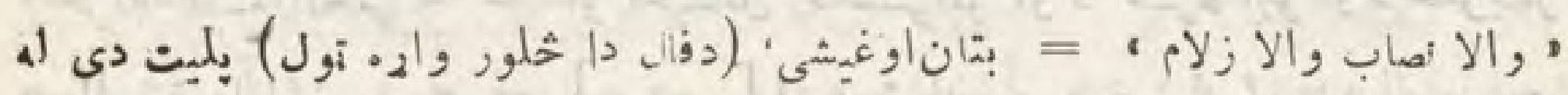

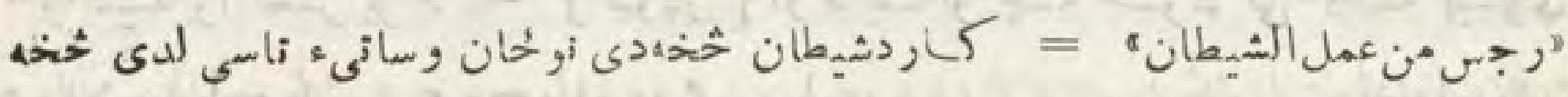

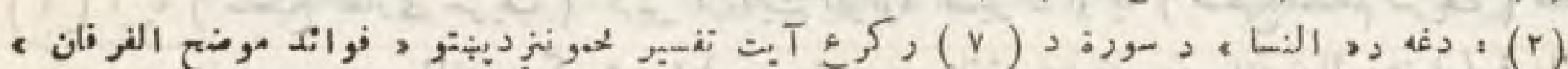

$$
\begin{aligned}
& \text { 1. }
\end{aligned}
$$

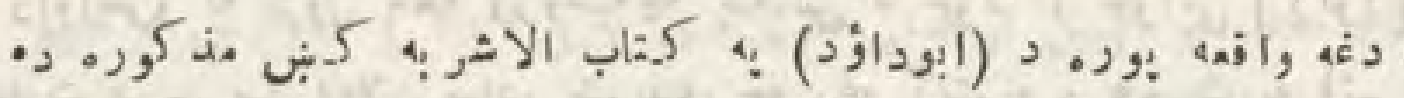

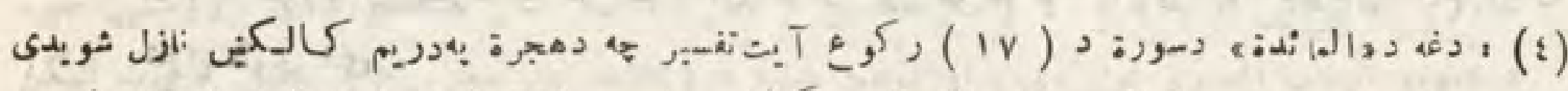

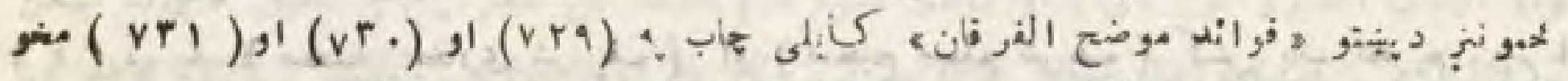

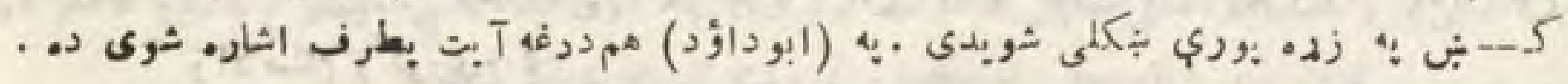




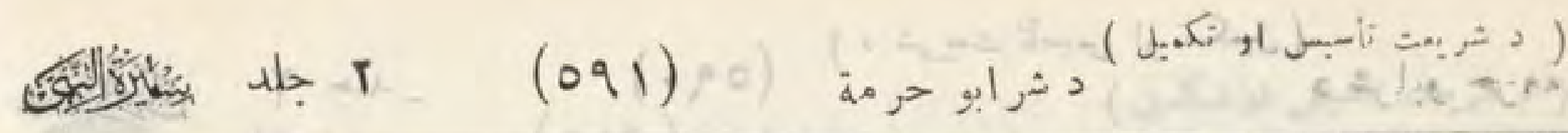

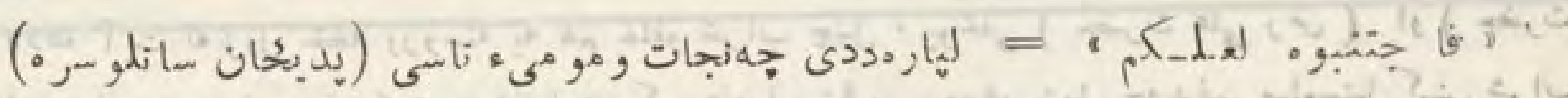

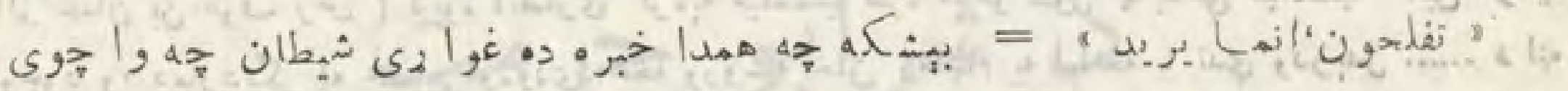

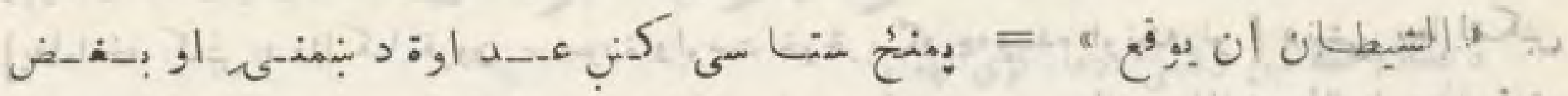
, أن

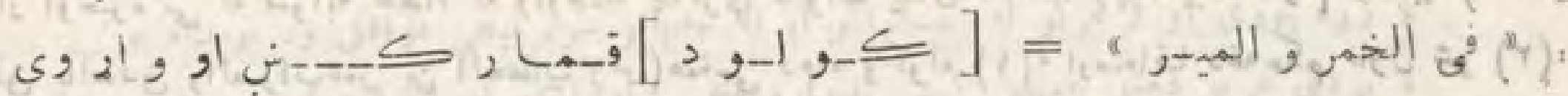

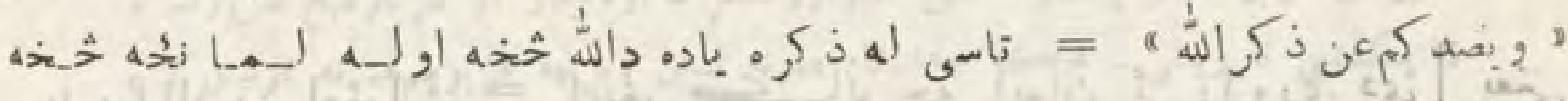

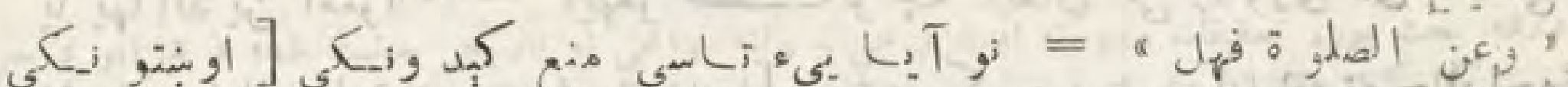
لى

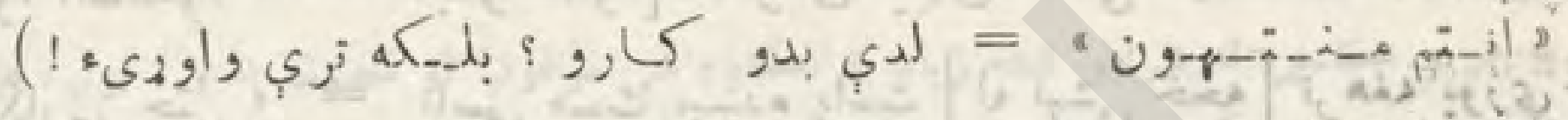

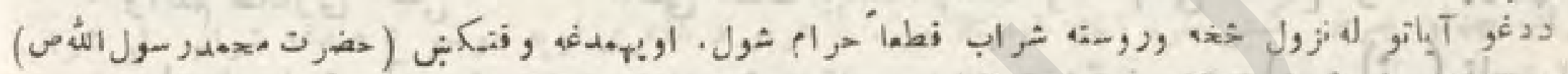

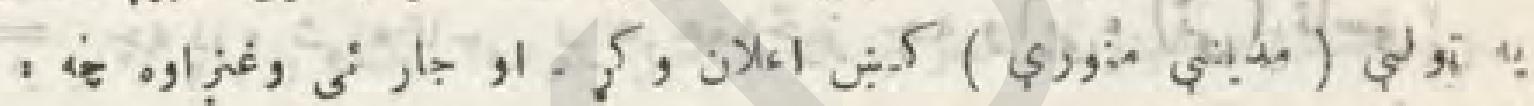

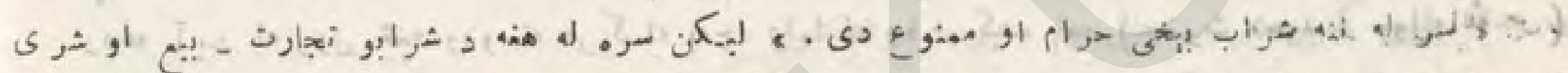

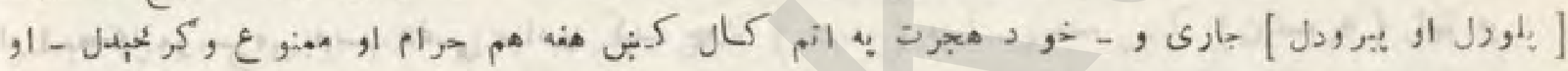

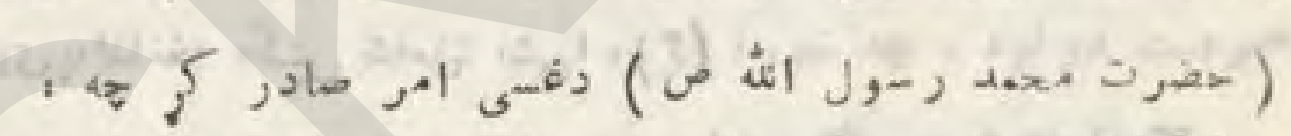

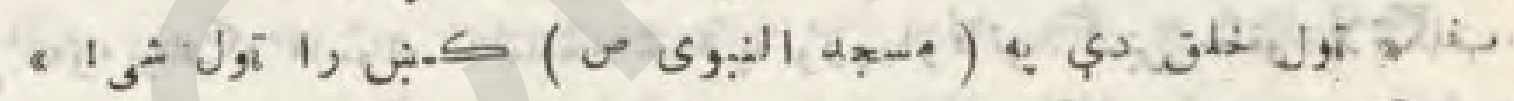

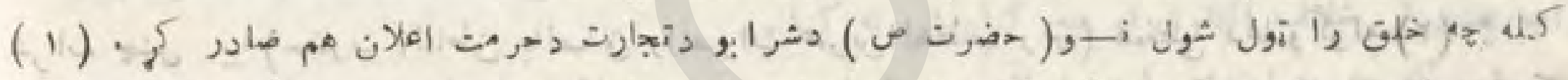

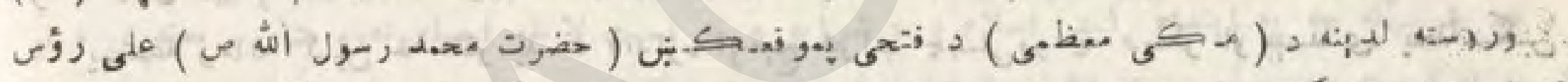

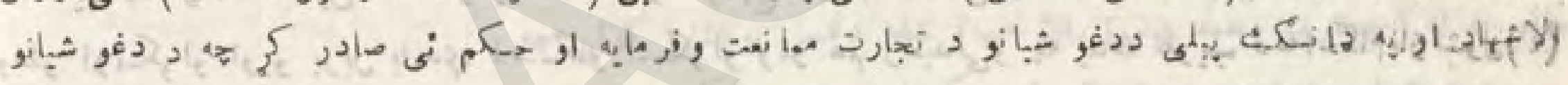

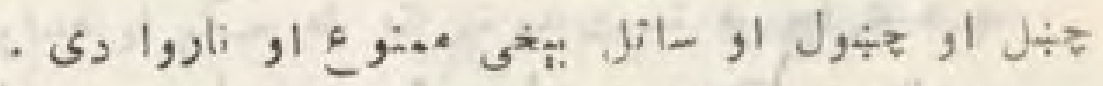

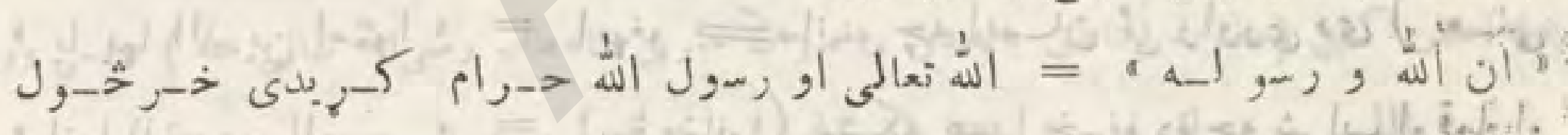

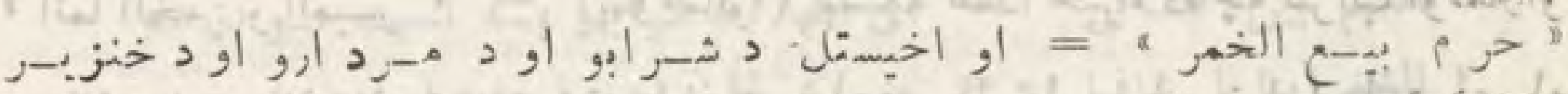

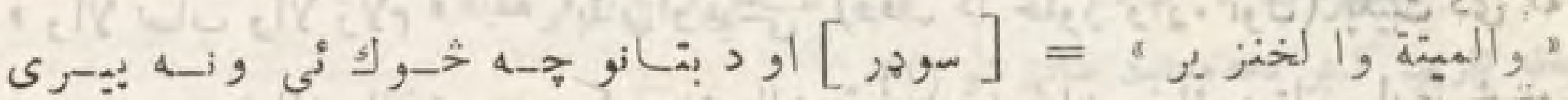

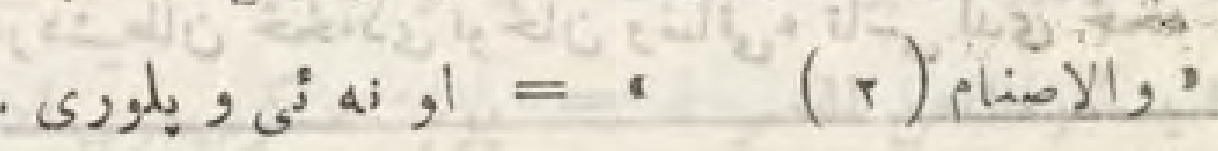

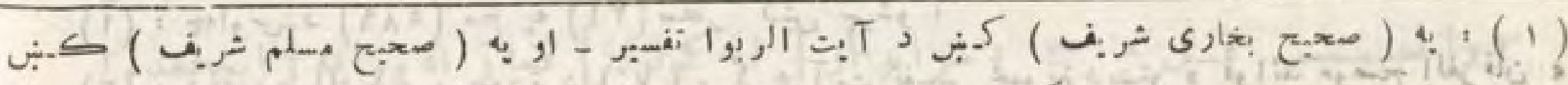

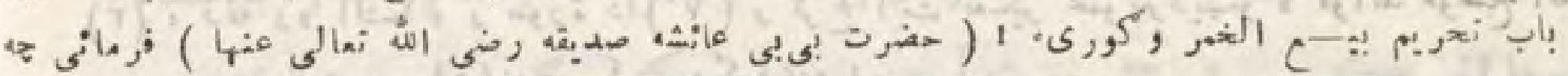

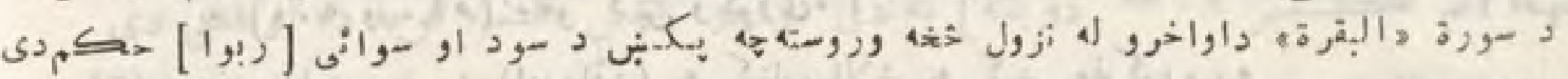

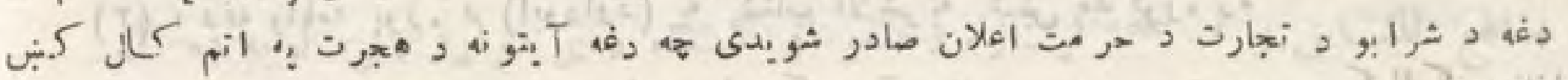

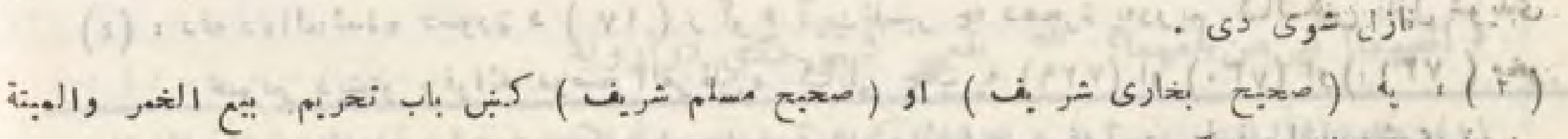

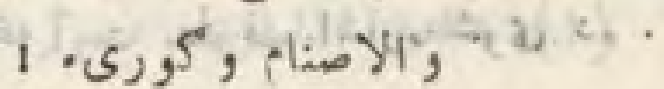




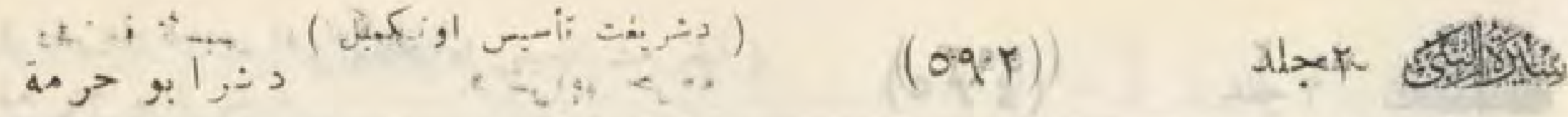

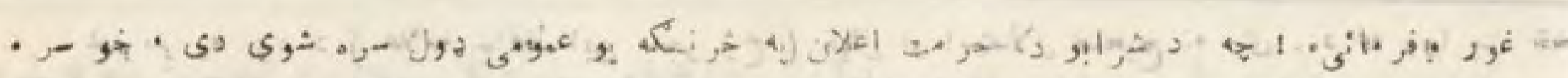

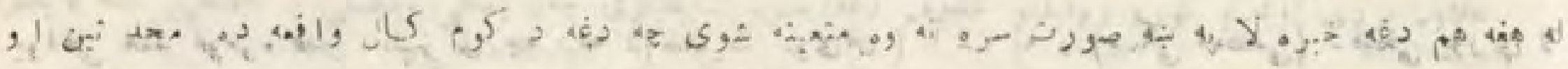

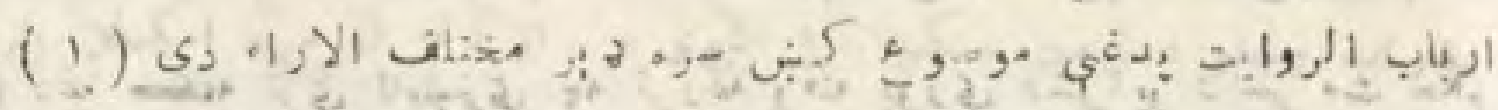

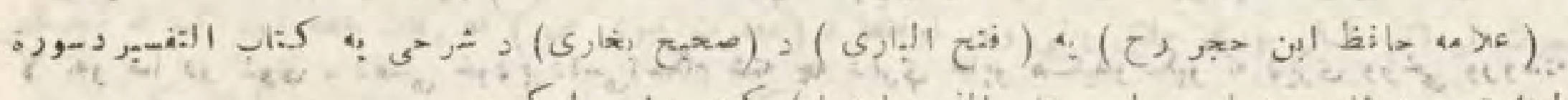

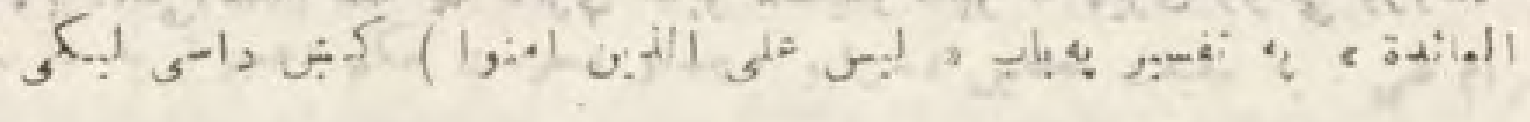

$4.4 \% \div 6-2 \%$

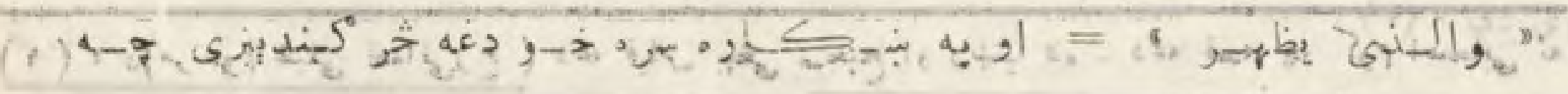

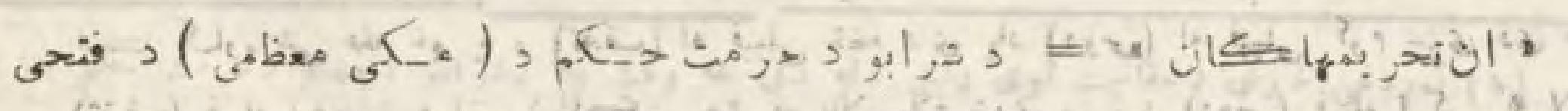

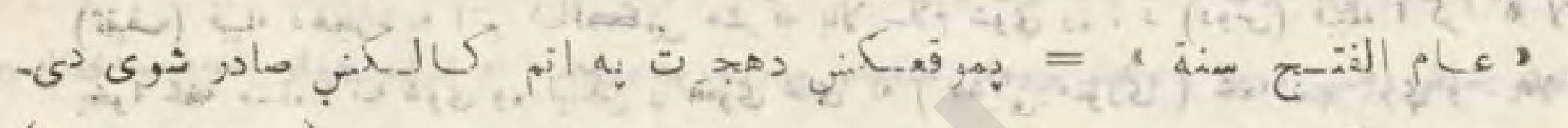

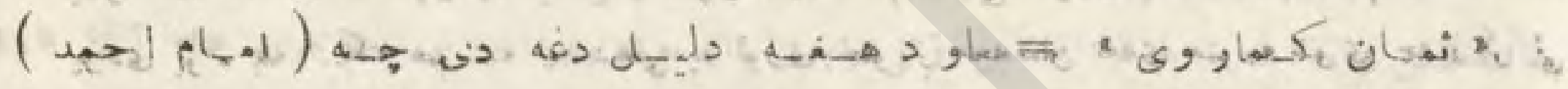
إس

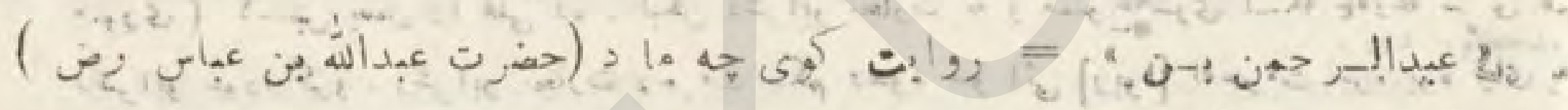

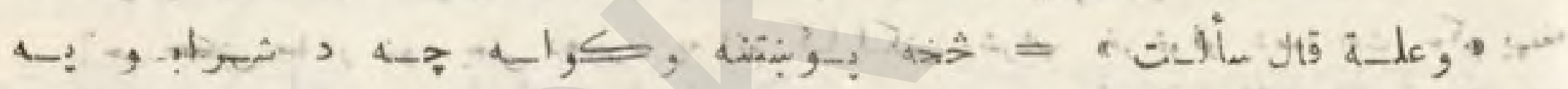

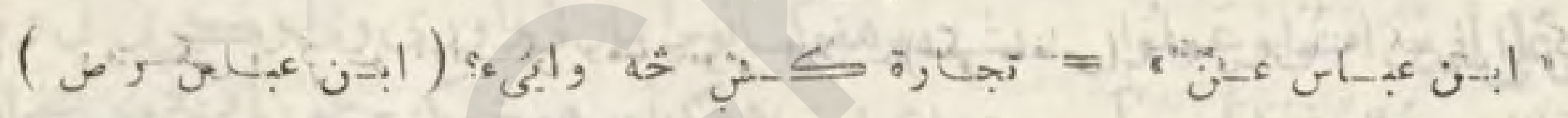

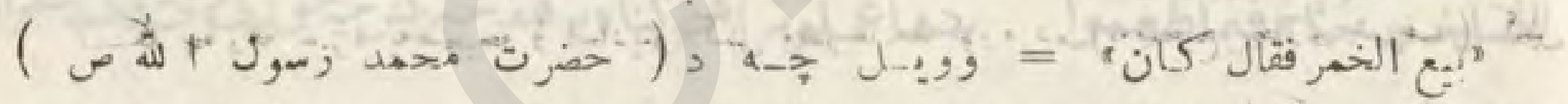

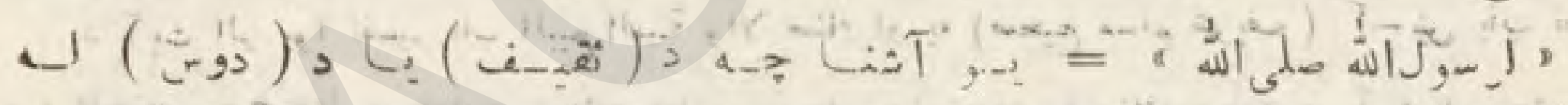
"O. O.

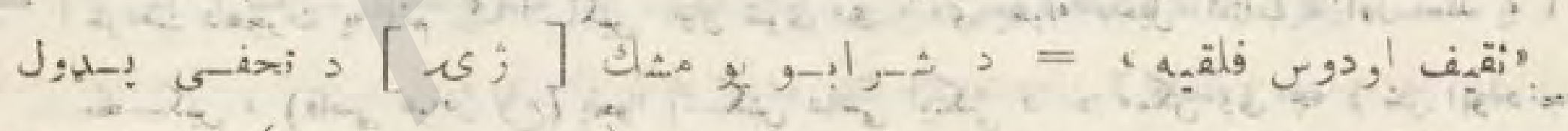

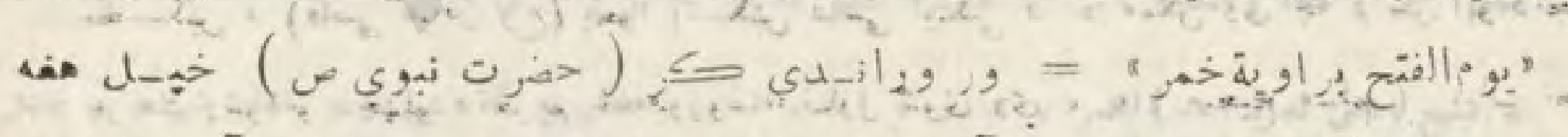

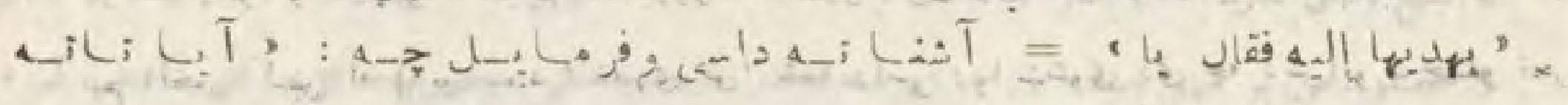

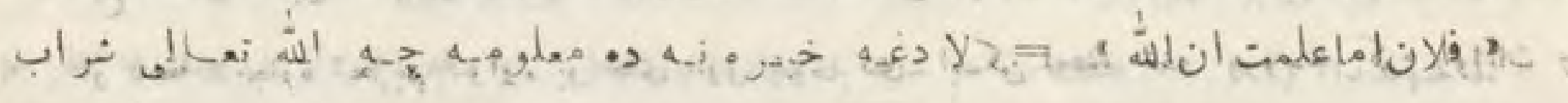

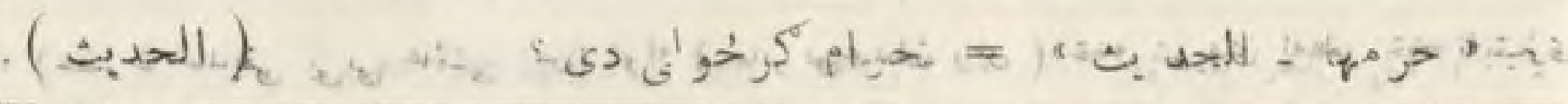

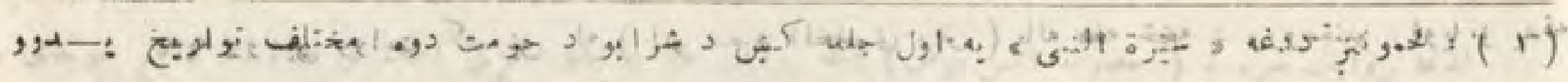

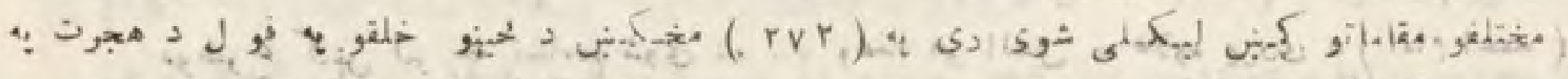

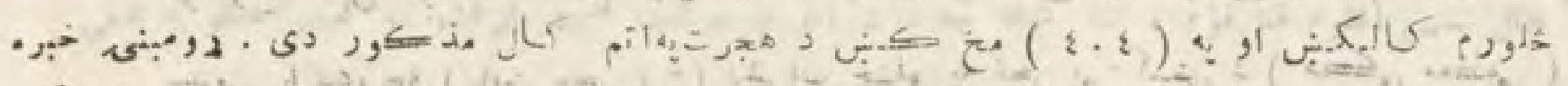

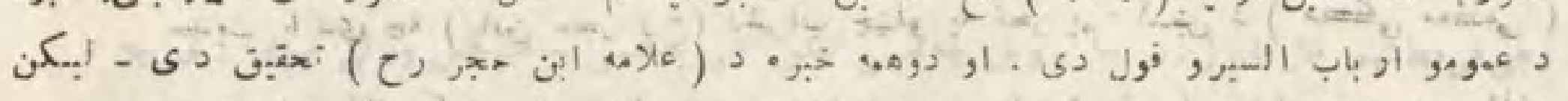
o

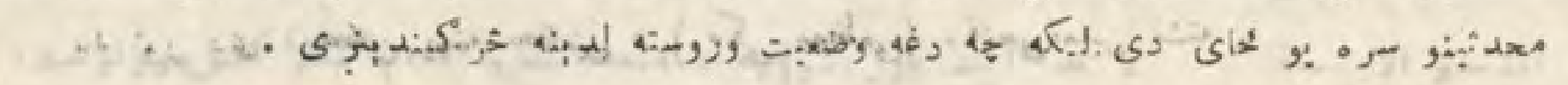




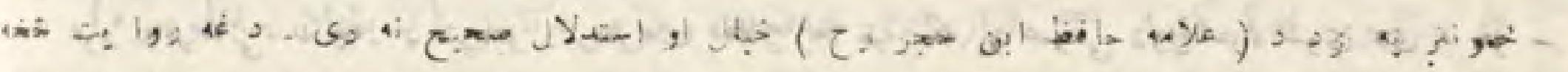

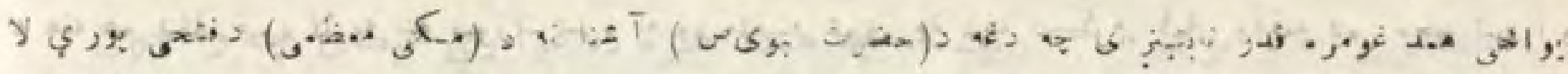

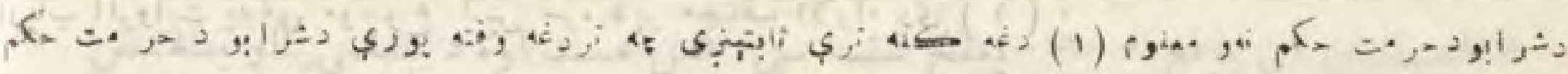
$\because$ : (ب)

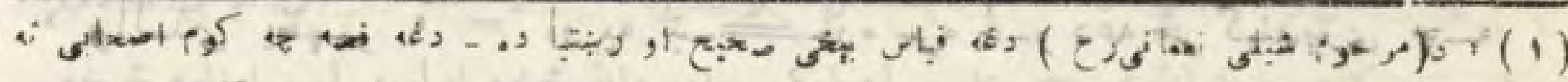

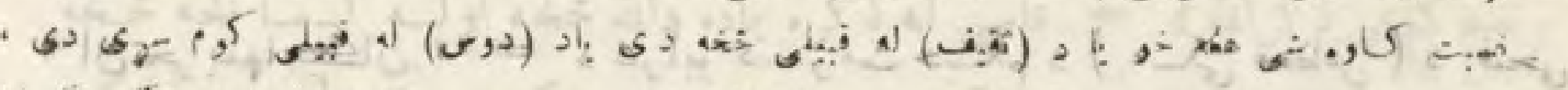

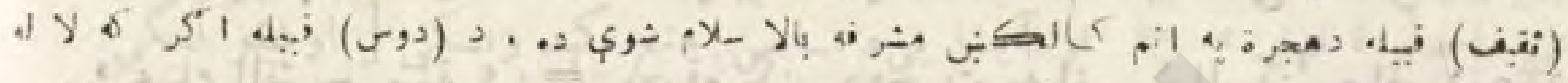

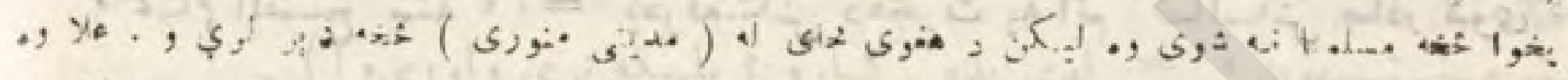

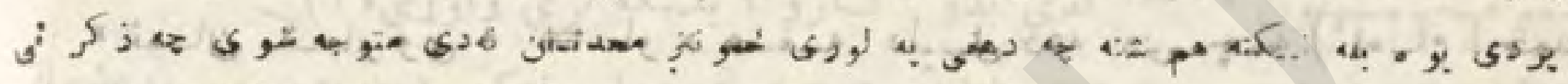

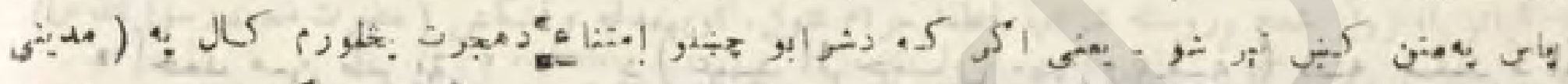

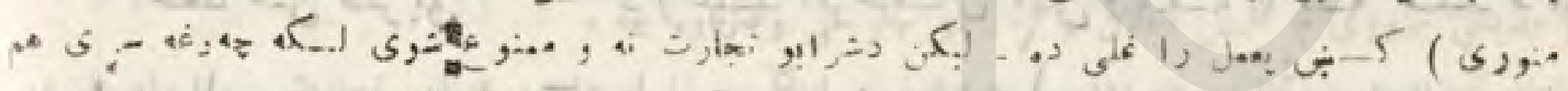

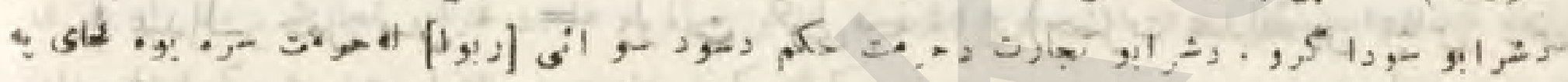

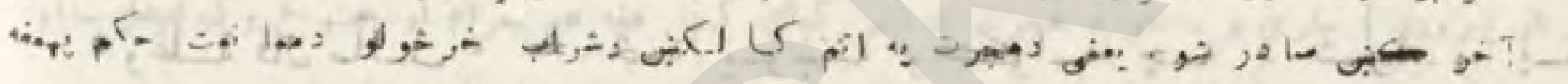

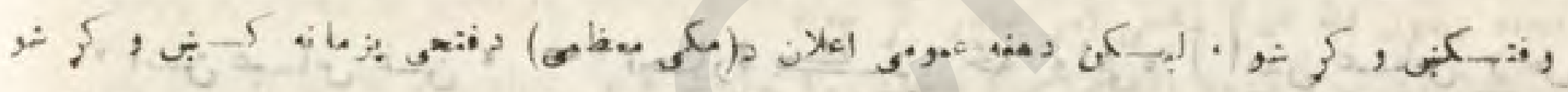

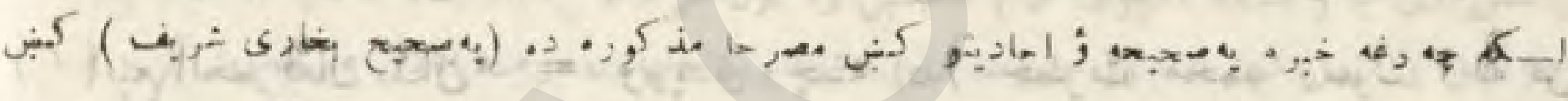

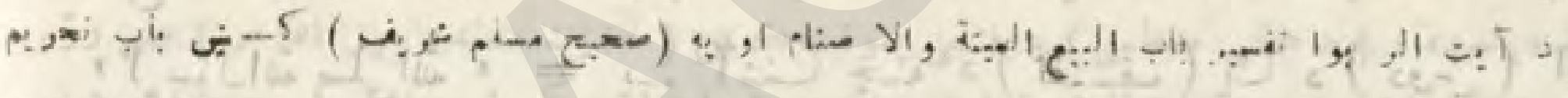

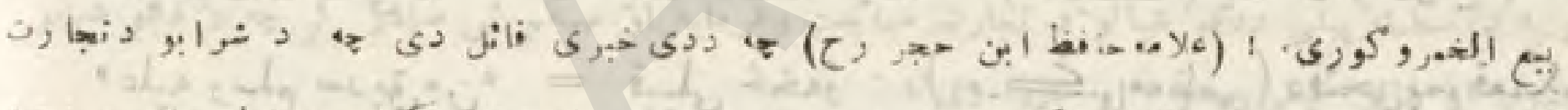

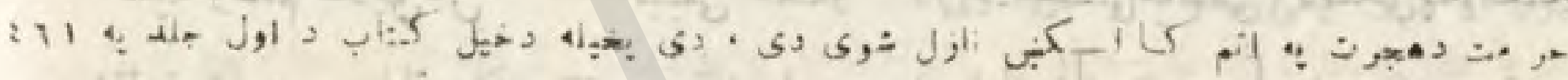

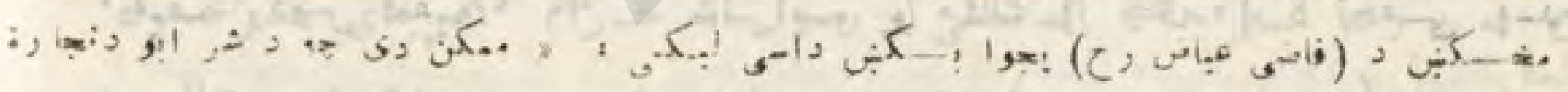

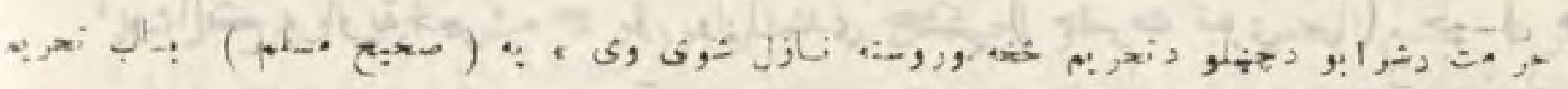

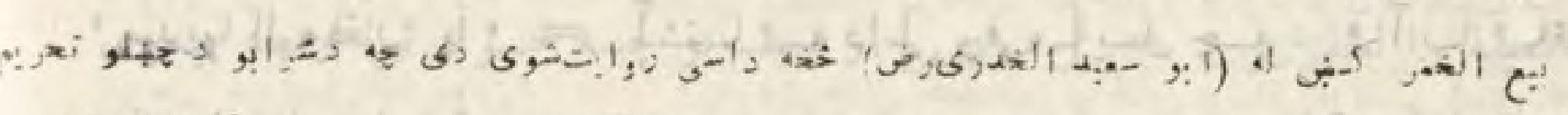

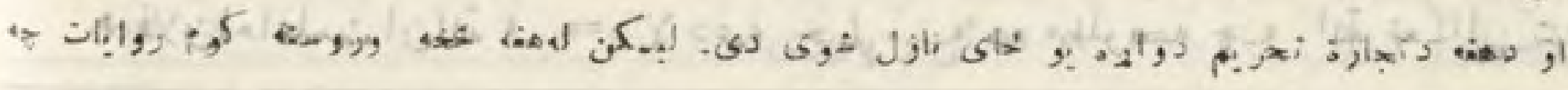

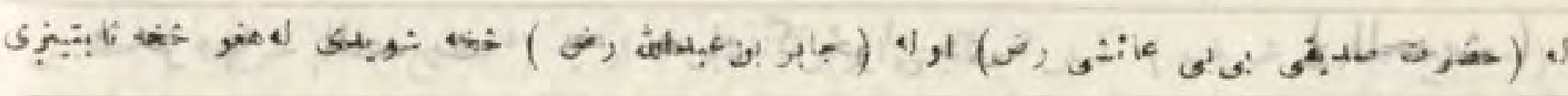

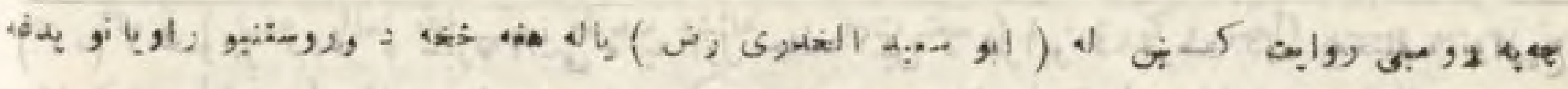
c

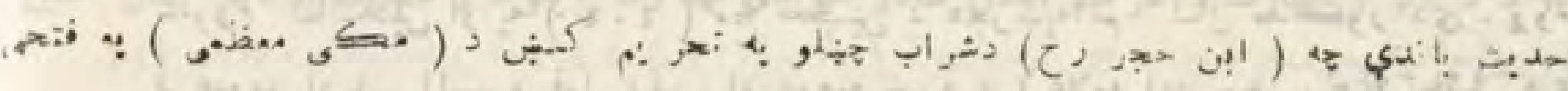

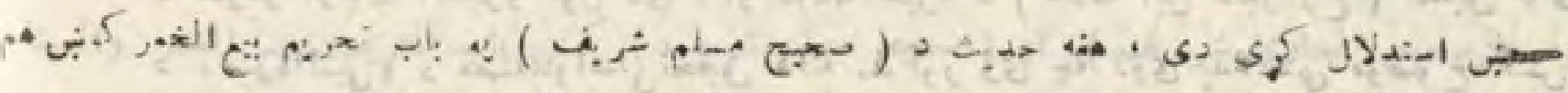

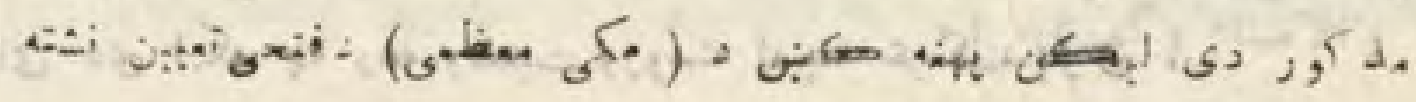




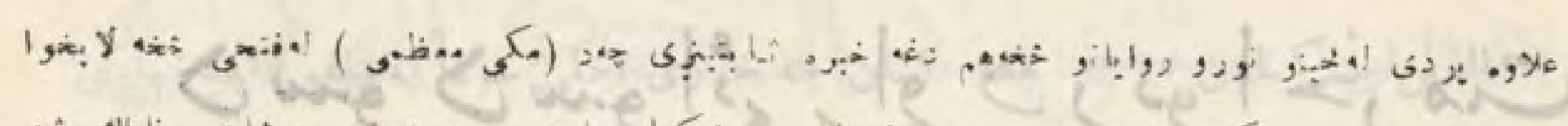

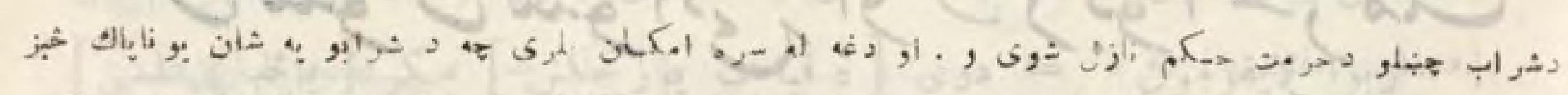

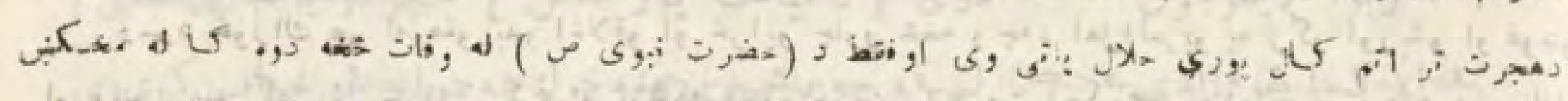

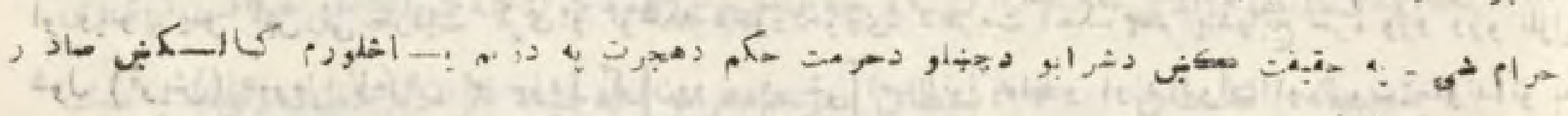
(1) . ज s,

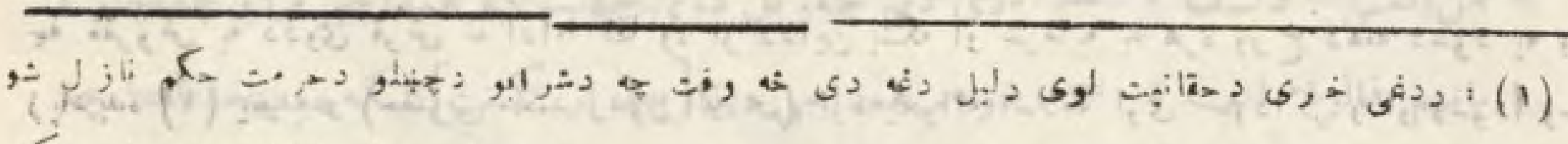

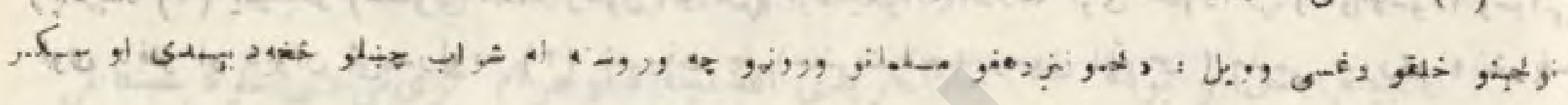

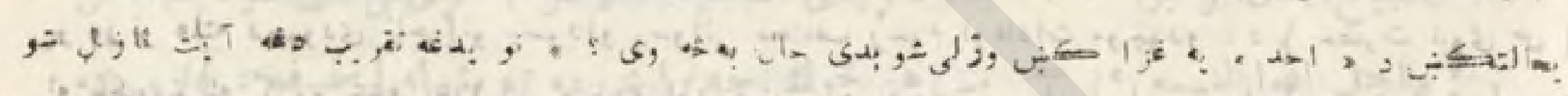

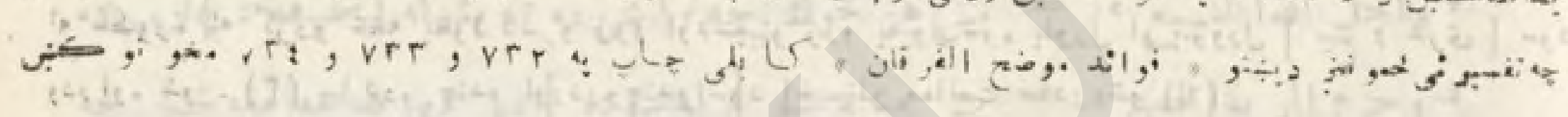
92, 1 ,

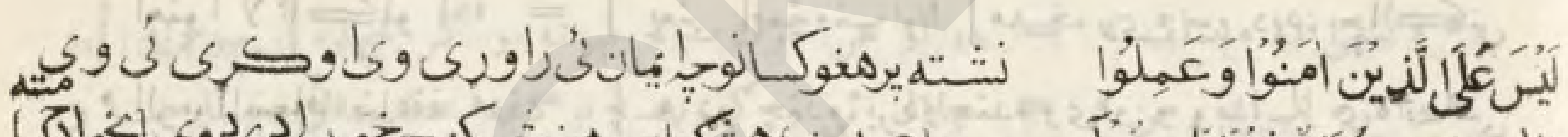

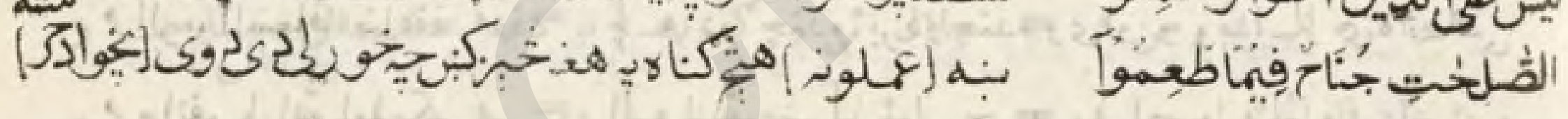

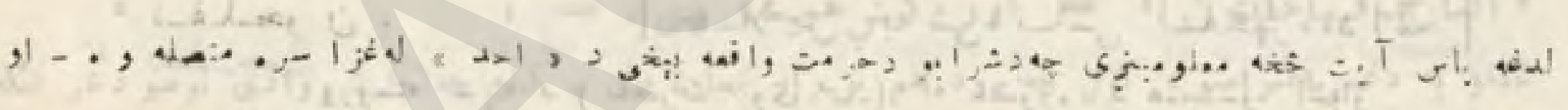

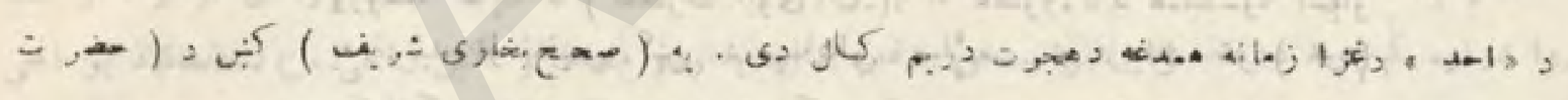

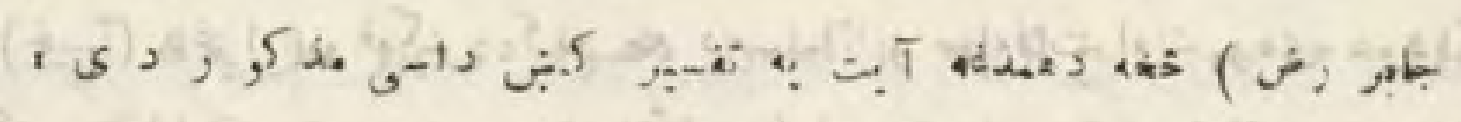

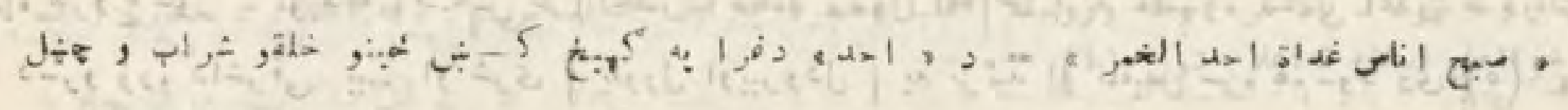

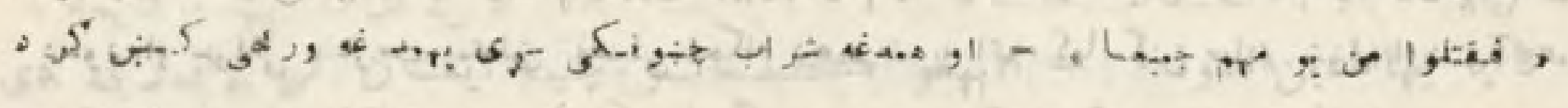

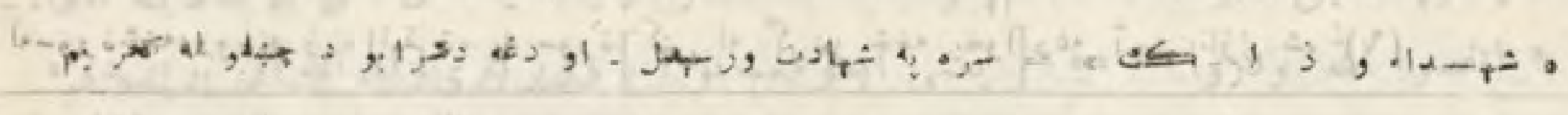

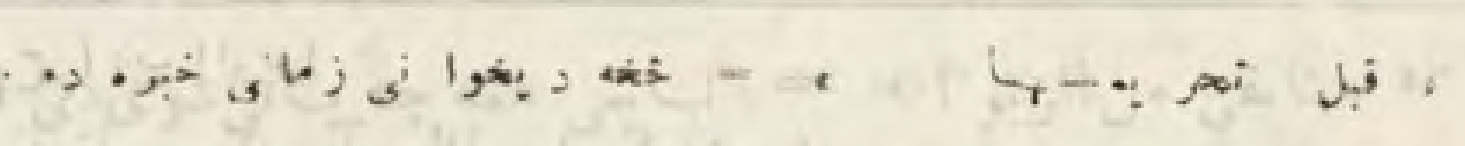

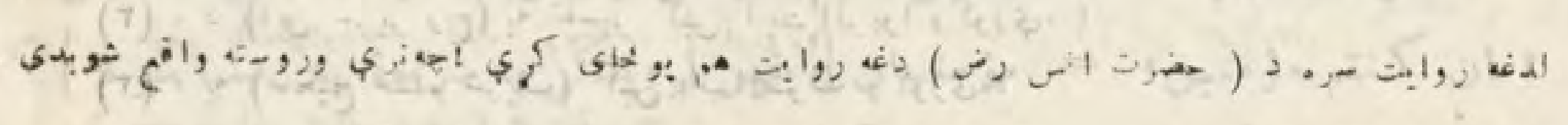

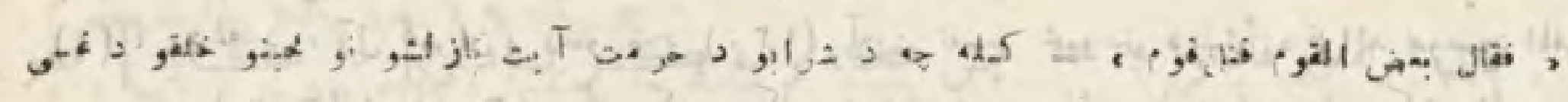

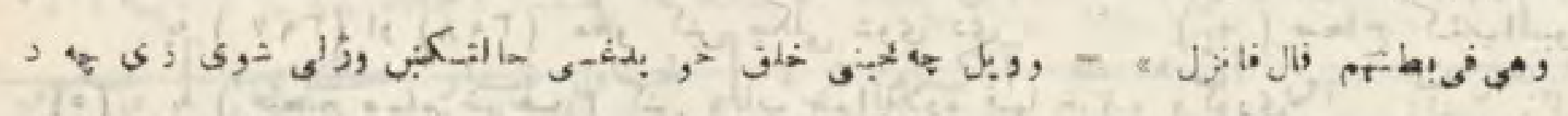

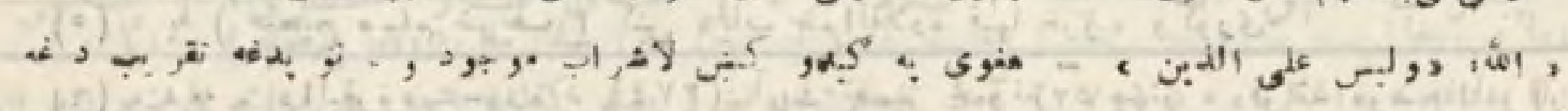
$[1=-g, 9045$, 


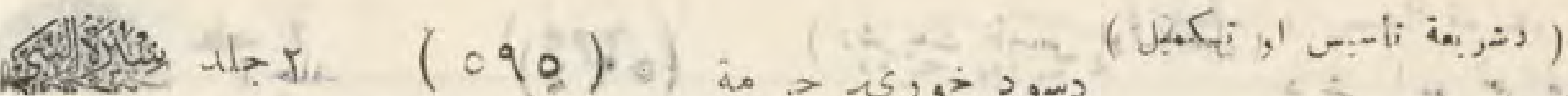

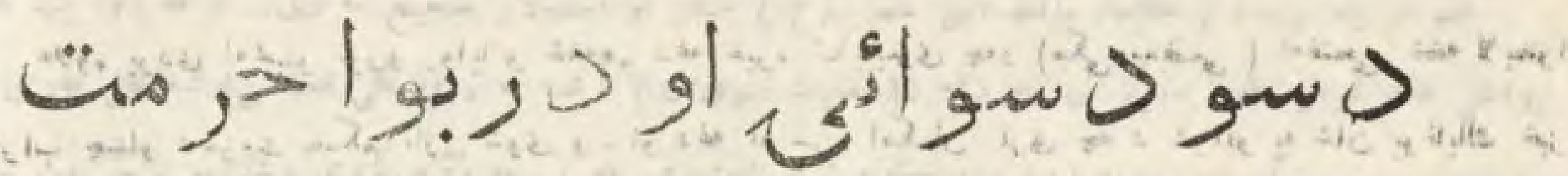

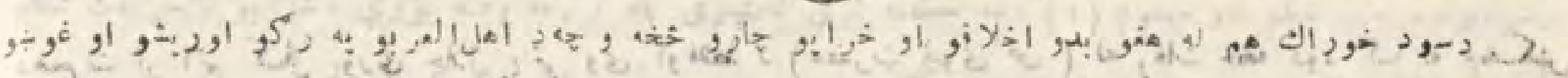

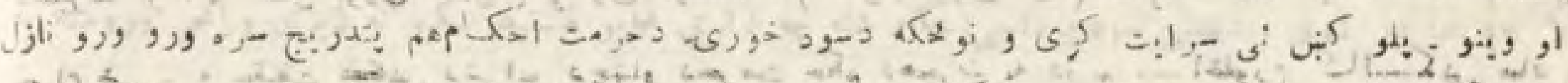

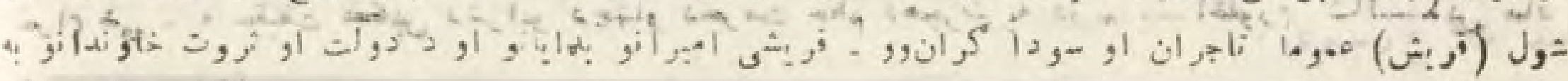

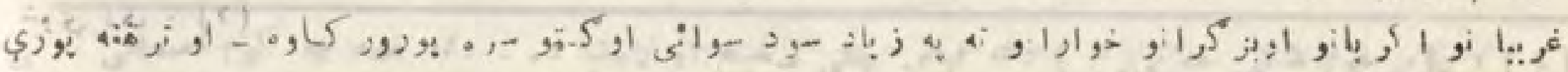

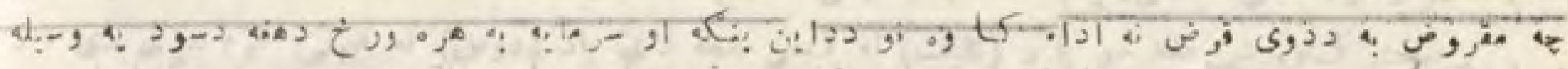

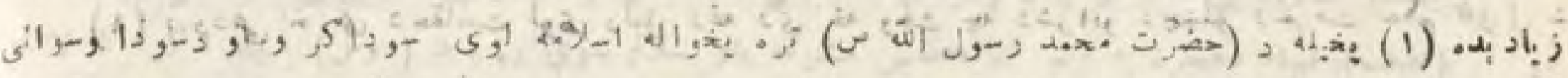

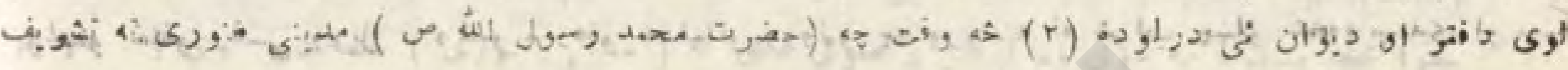

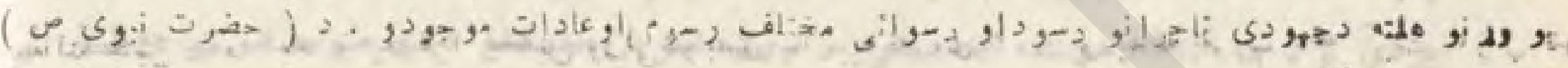

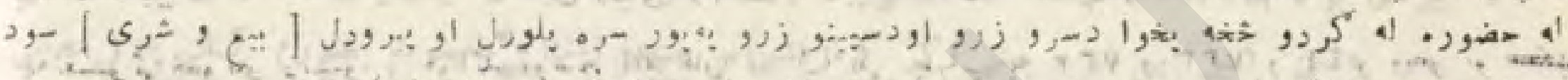
(z)
(r) -.,- 0 ,

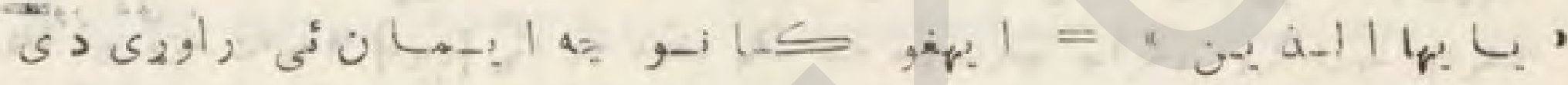

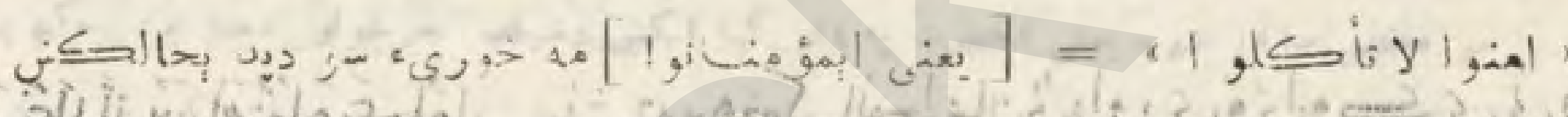

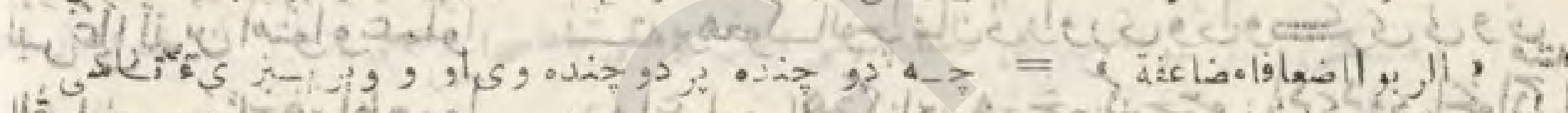

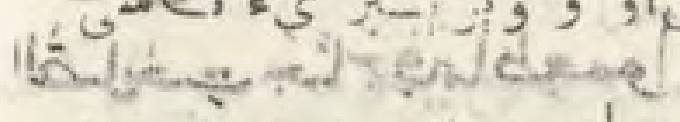

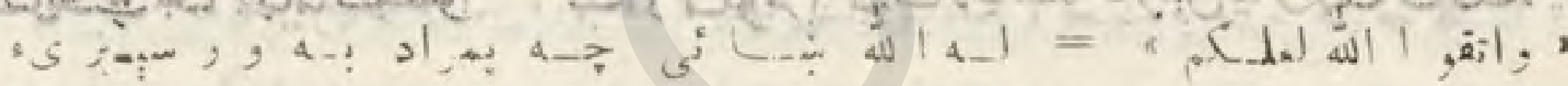

$$
\begin{aligned}
& \text { [ }
\end{aligned}
$$

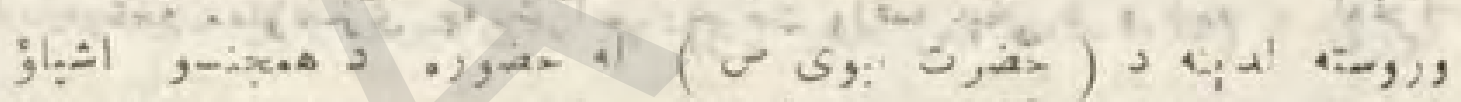

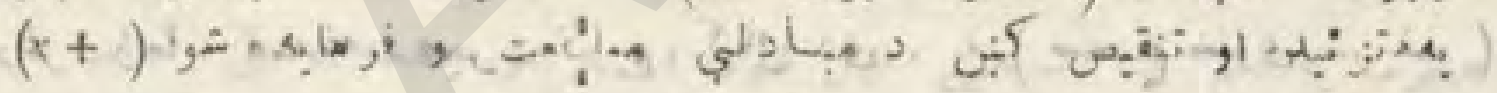

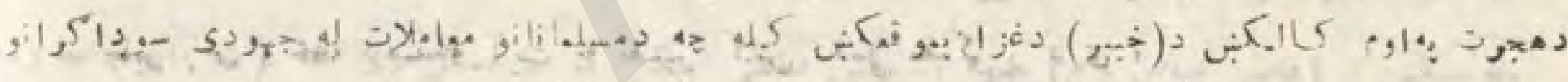

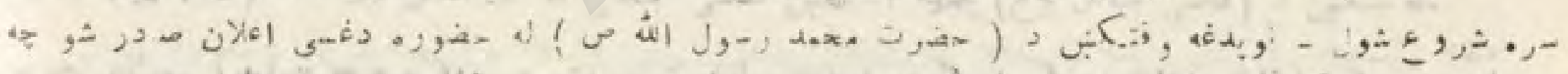

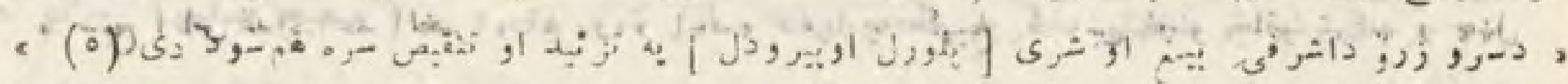

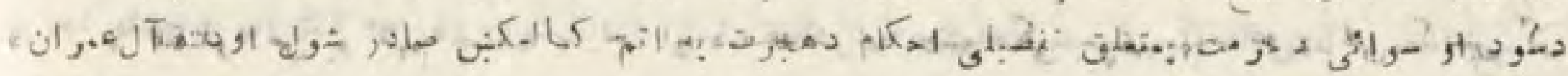

(1) 5 (1)

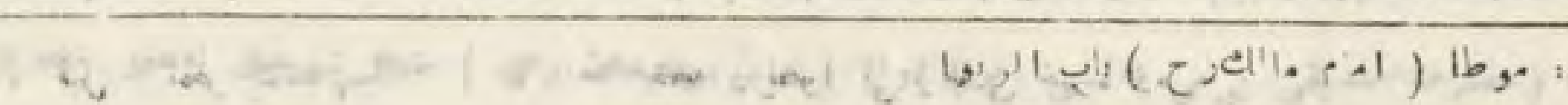

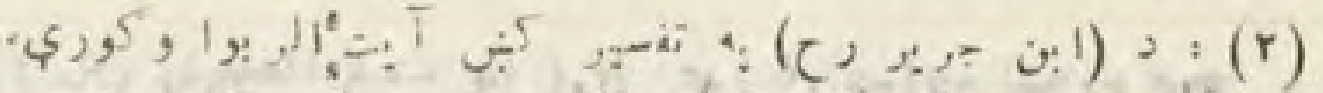

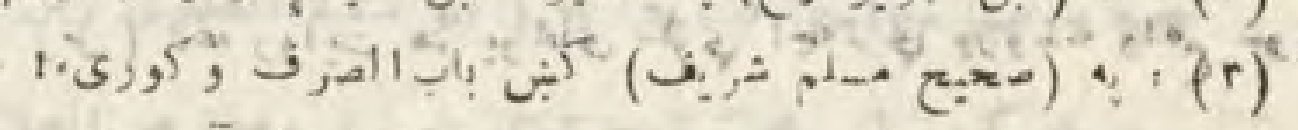

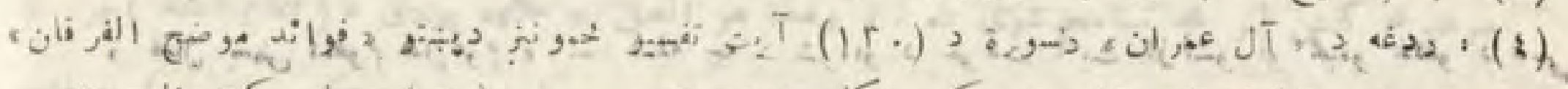

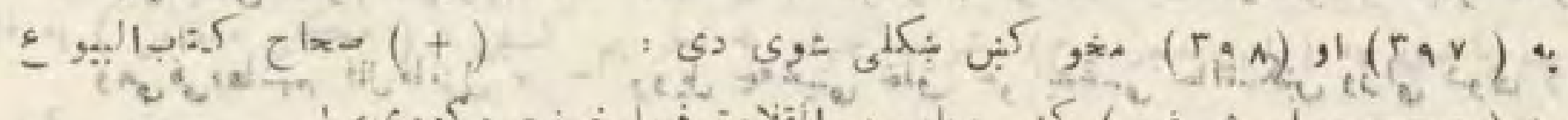

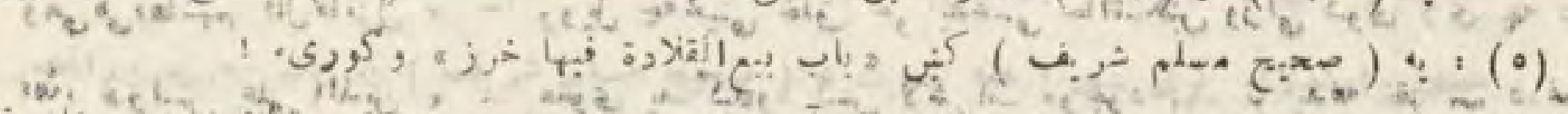

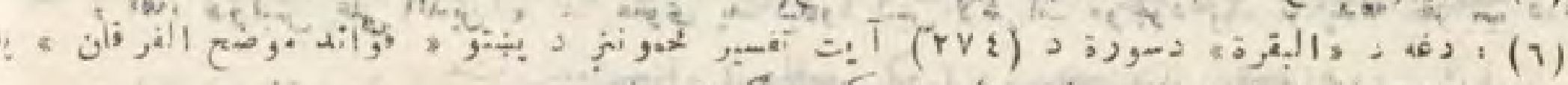

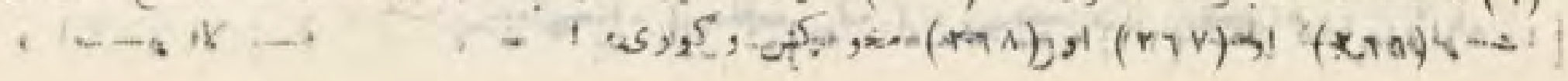




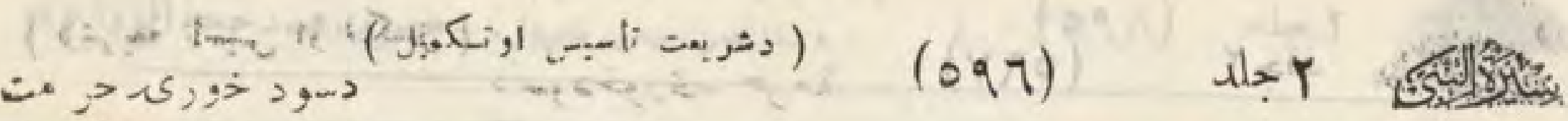

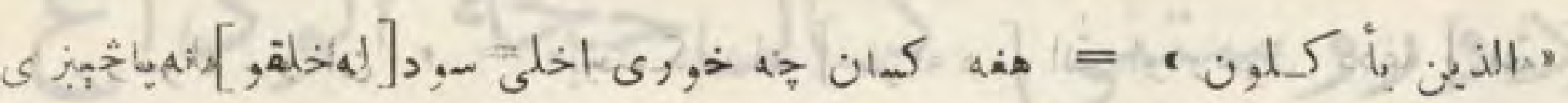

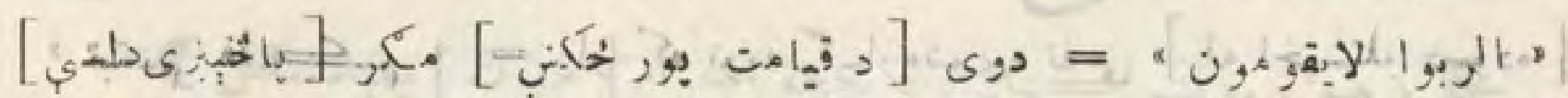
管 年

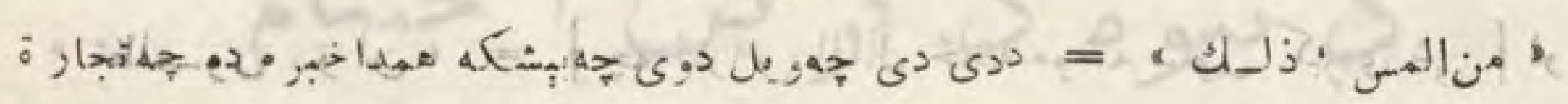

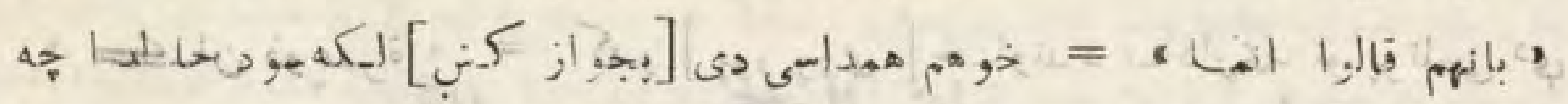

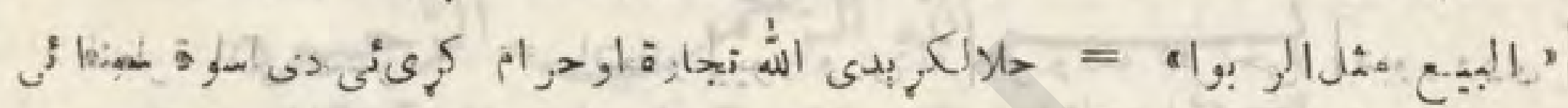

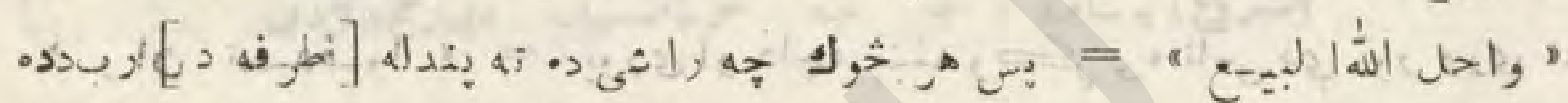

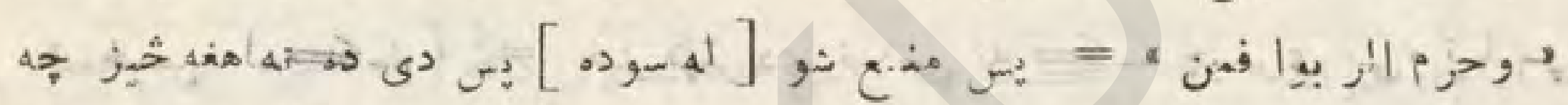

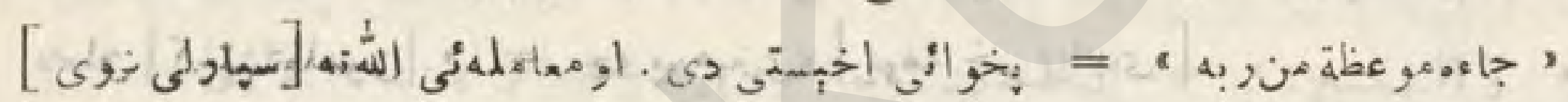

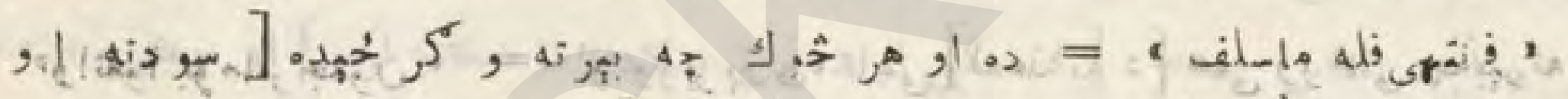

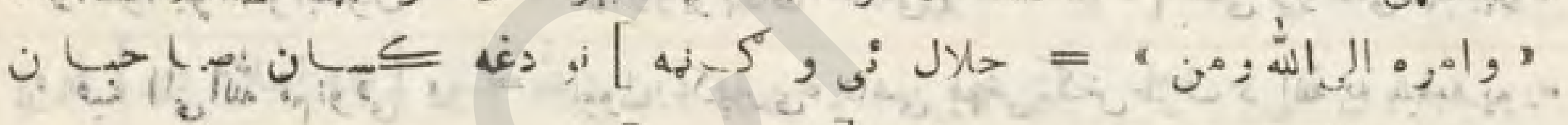

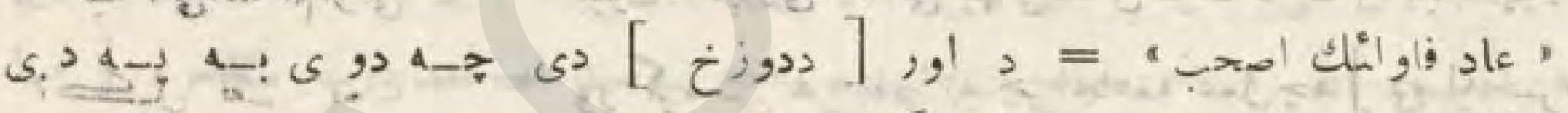

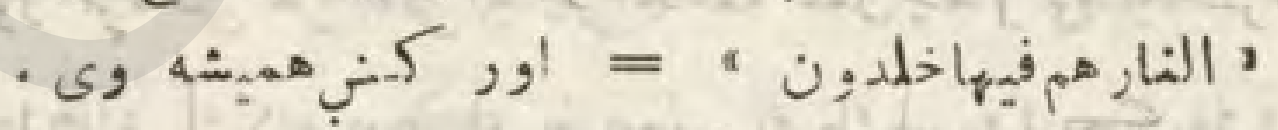

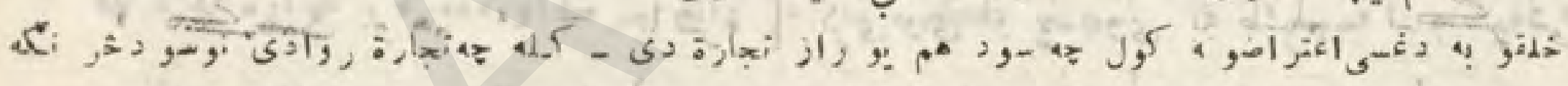

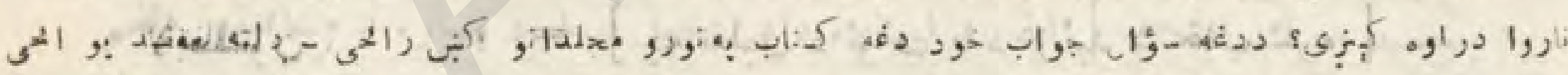

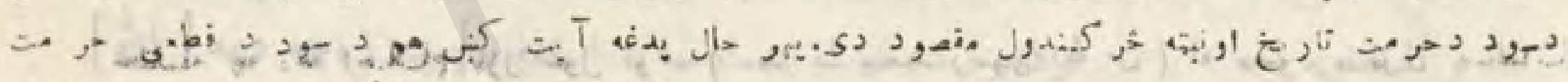

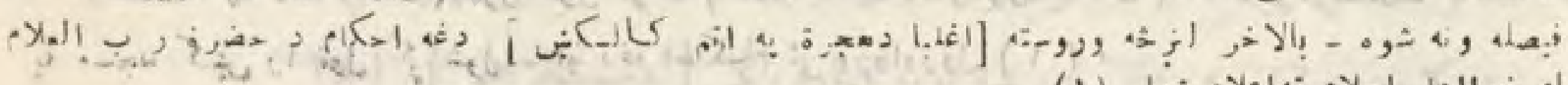

(1)

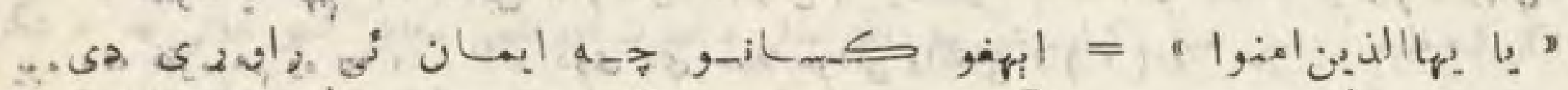

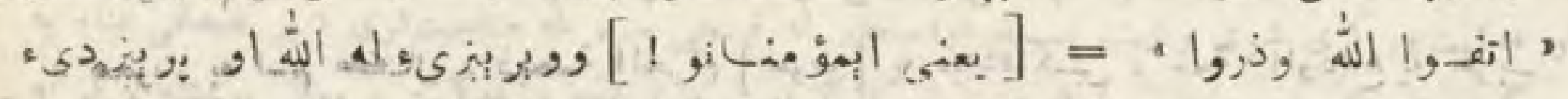
(

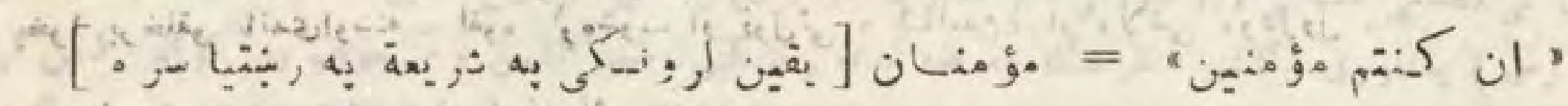

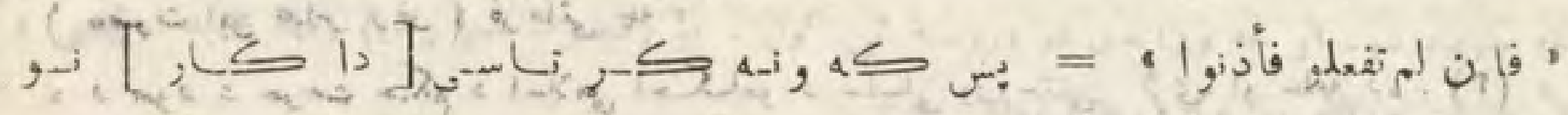

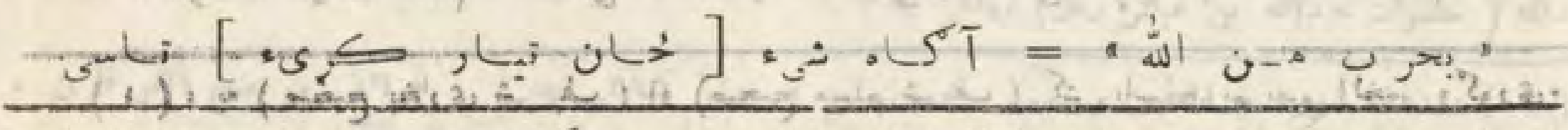
* $(\tau)=\because$ ( ) 
,

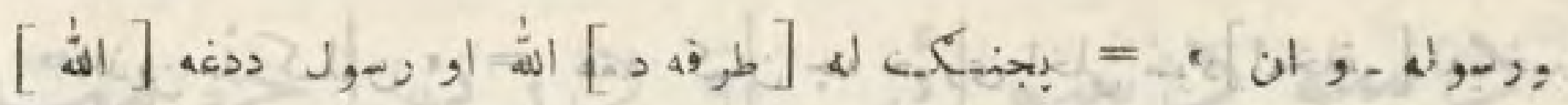

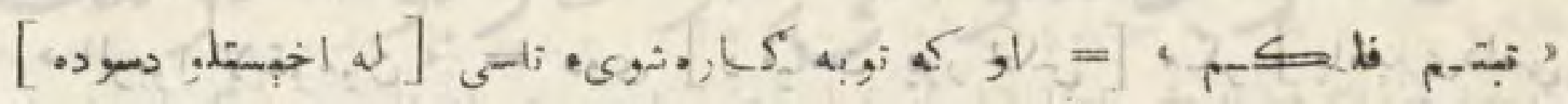

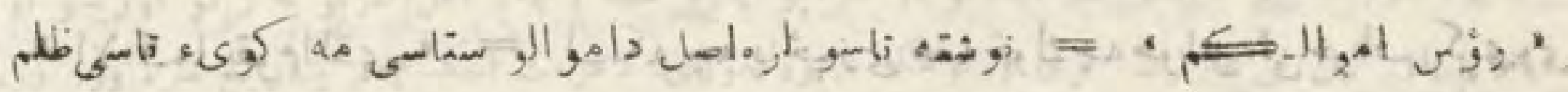

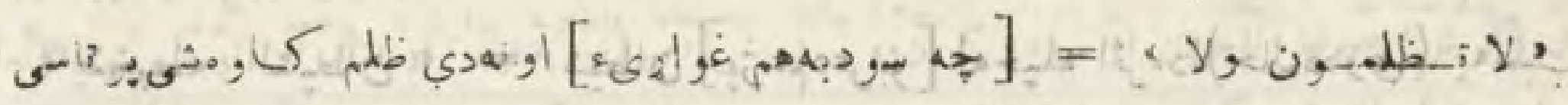

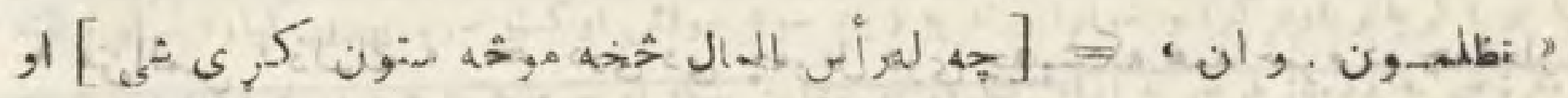
مد

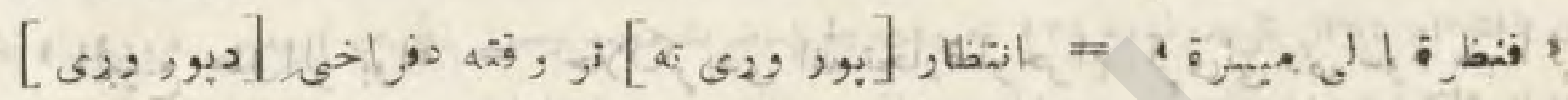
iا خ

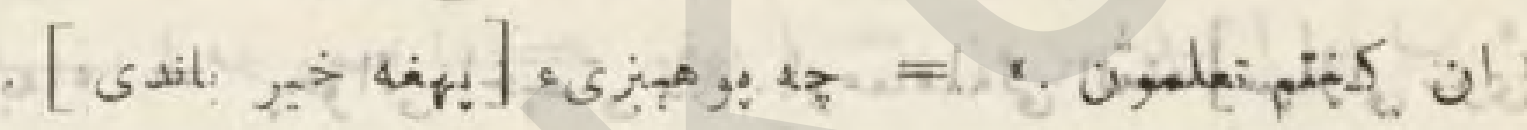

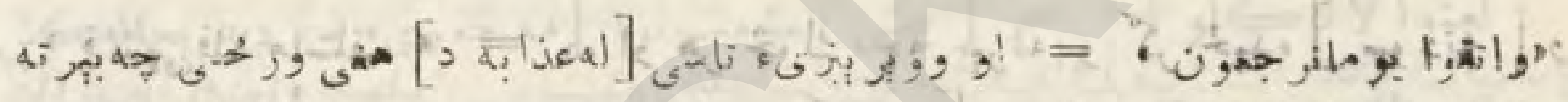

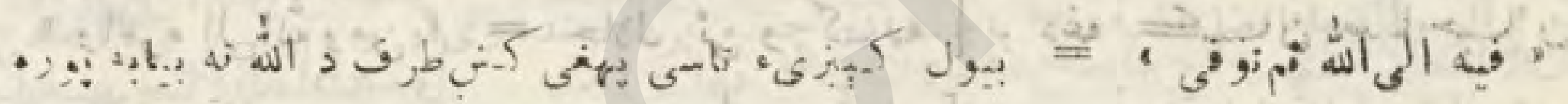

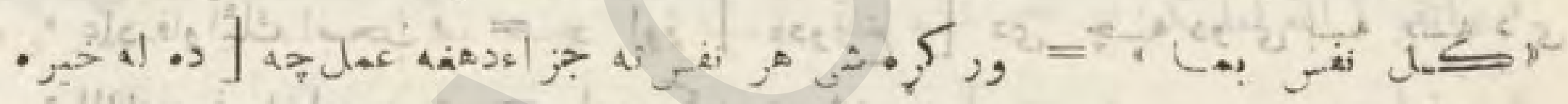

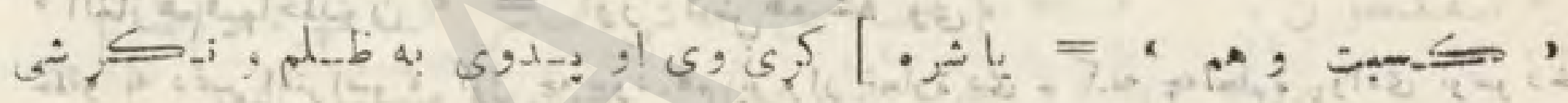

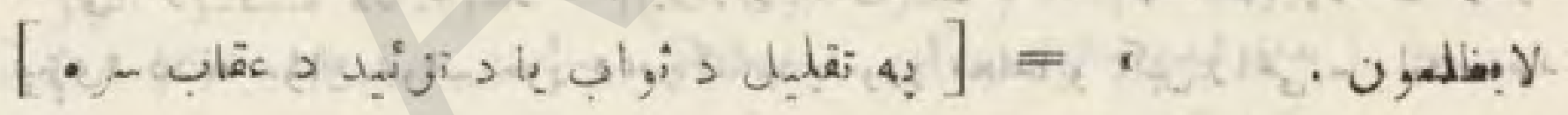

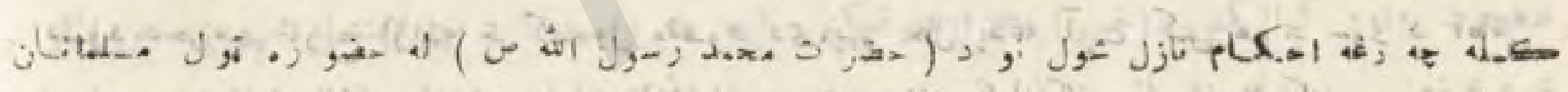

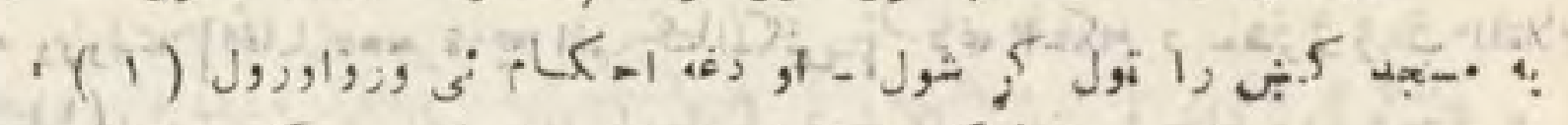

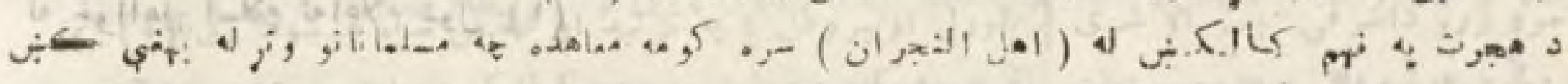

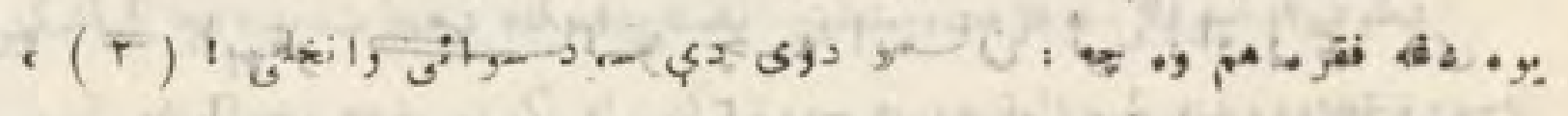

2

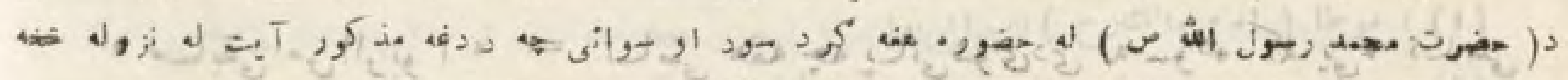

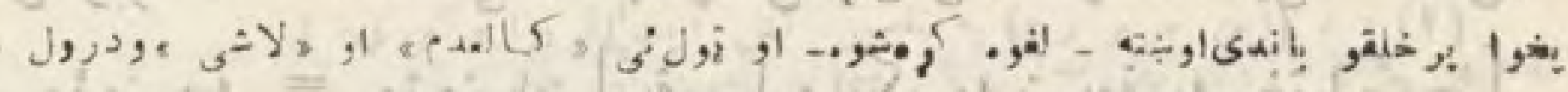

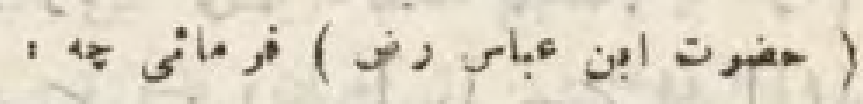

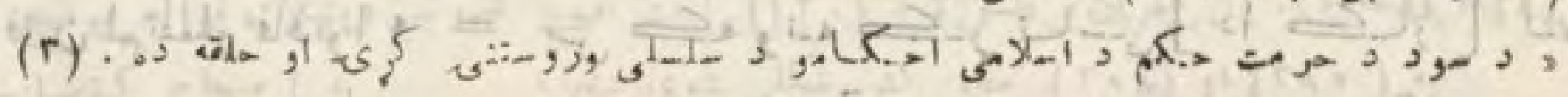

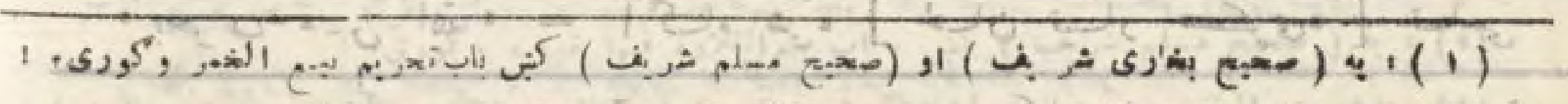

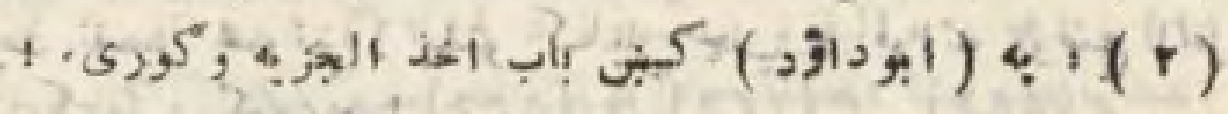
1. 


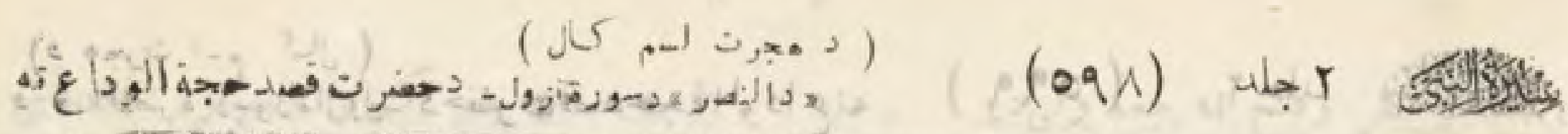

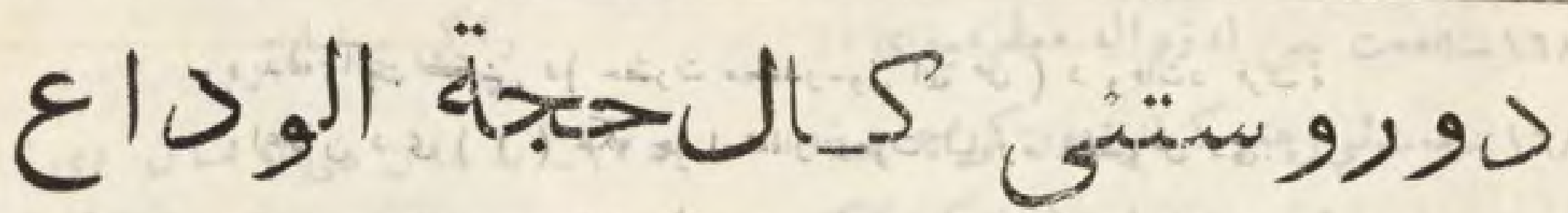

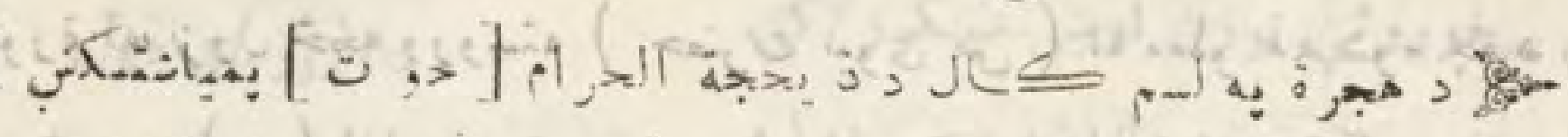

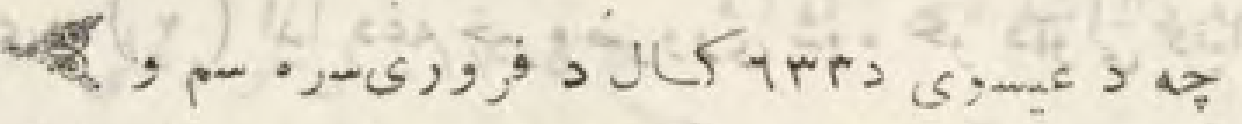
tris $>10,3090$

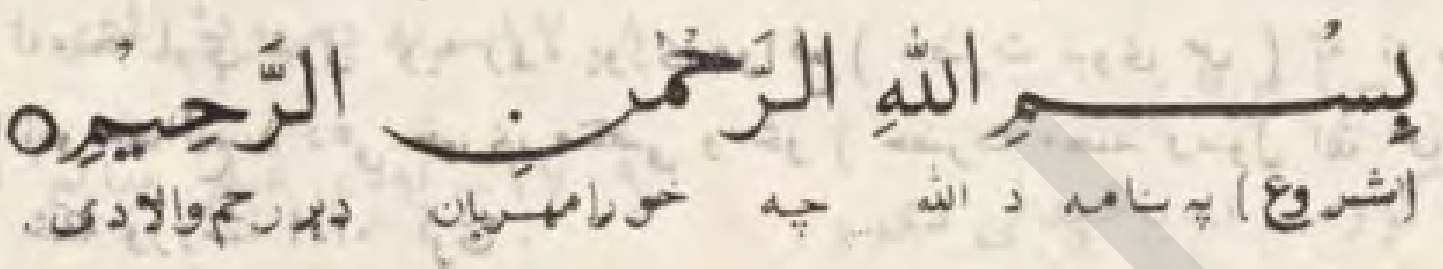

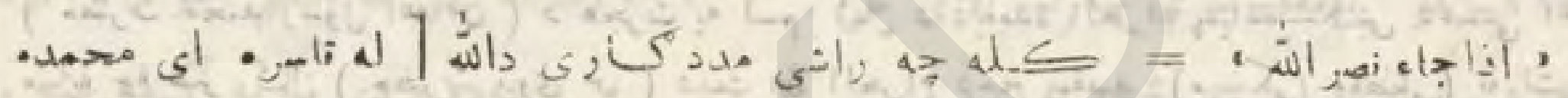

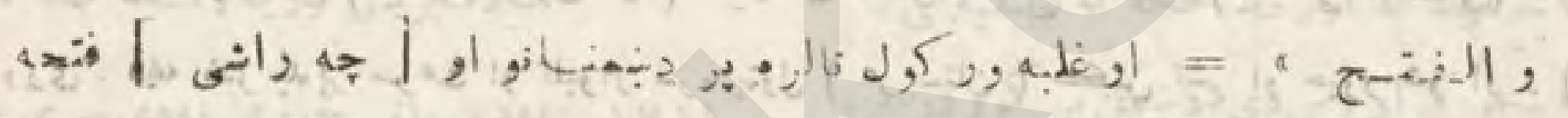

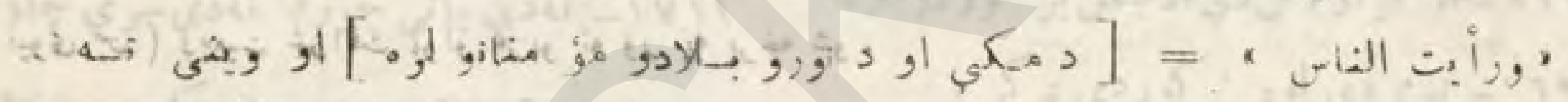

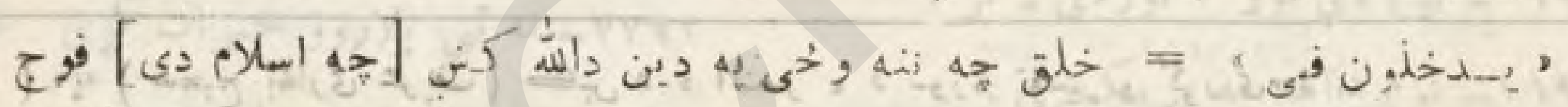

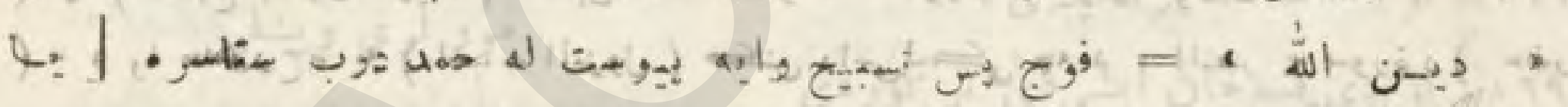

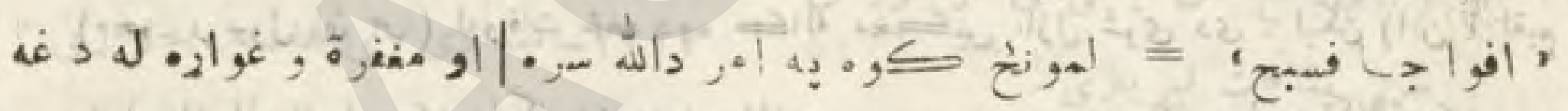

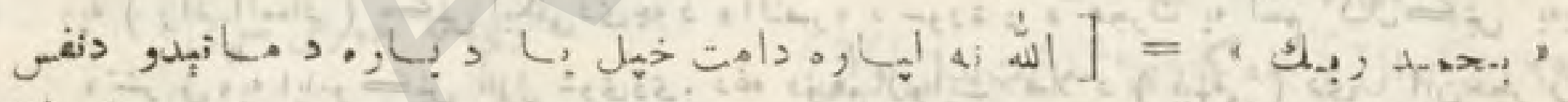

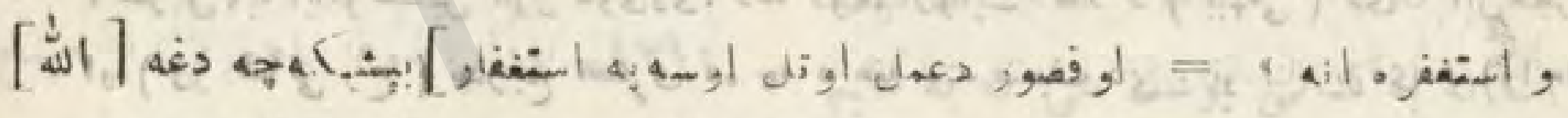

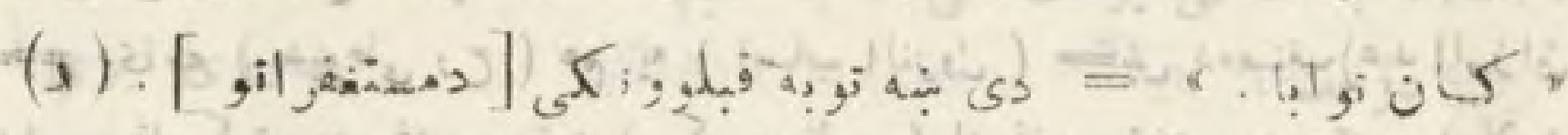

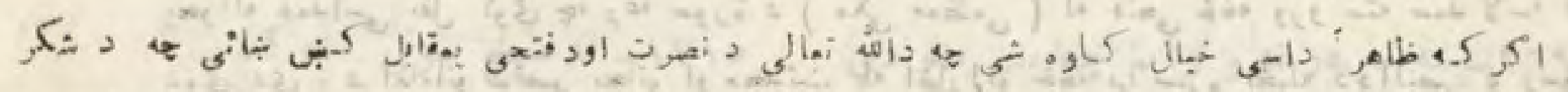

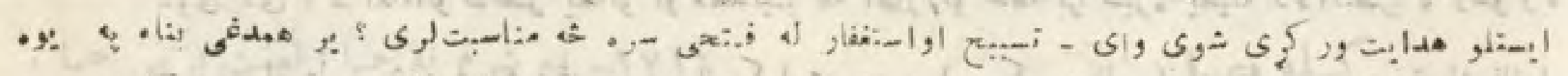
ه - ه

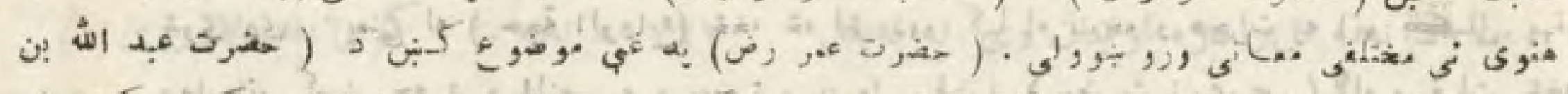

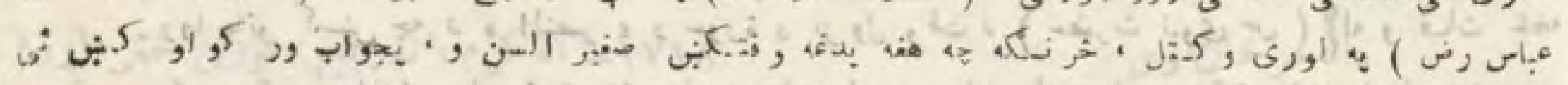
لز

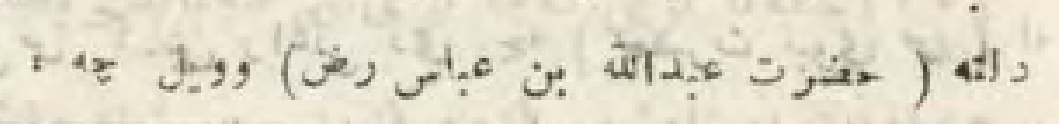

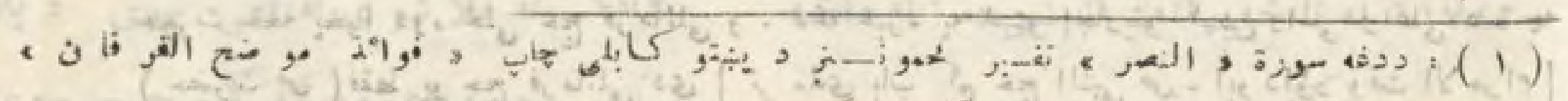
1 : 


\section{4.}

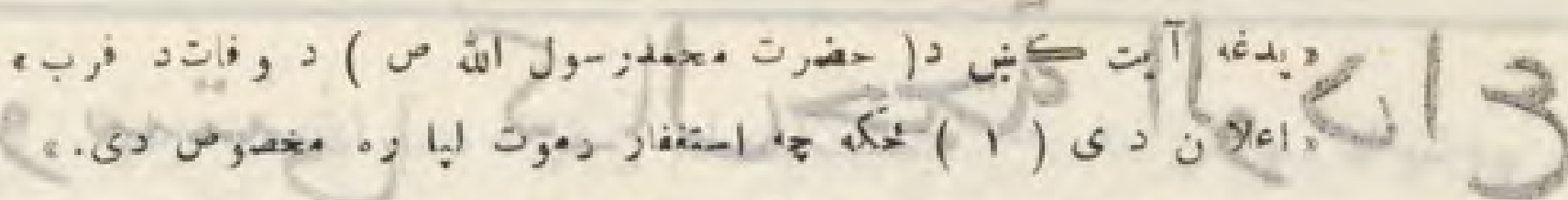

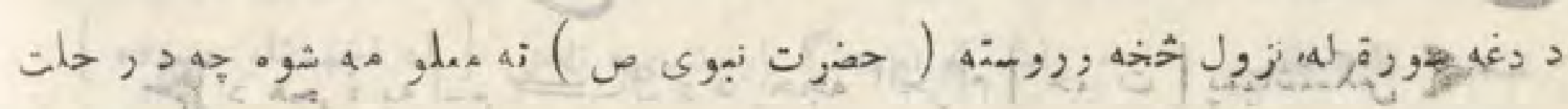

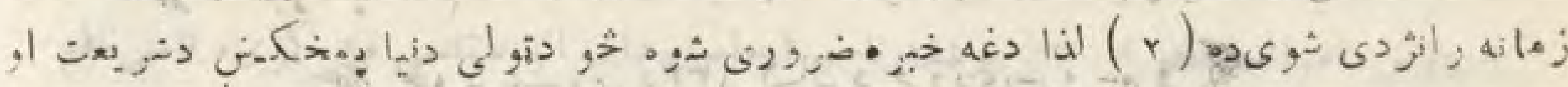

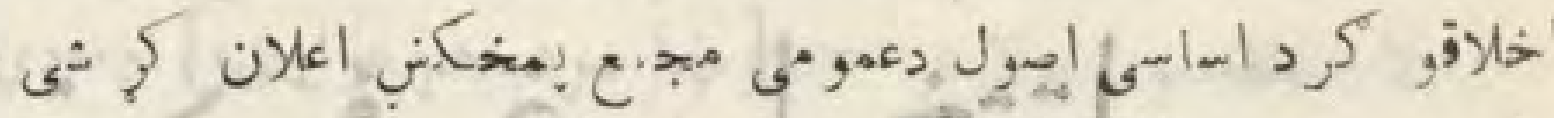

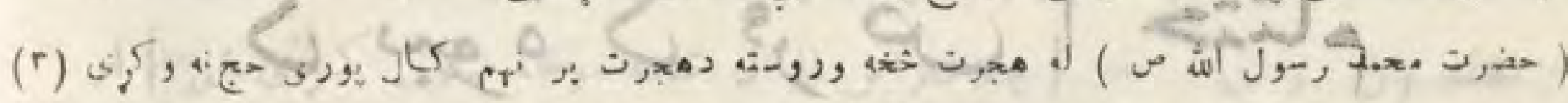

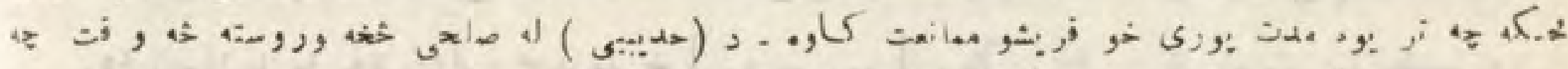

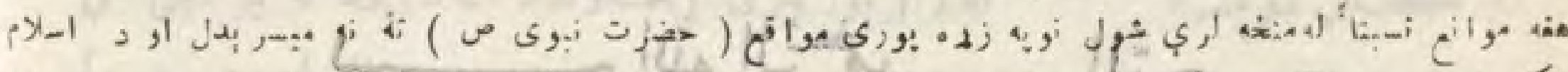

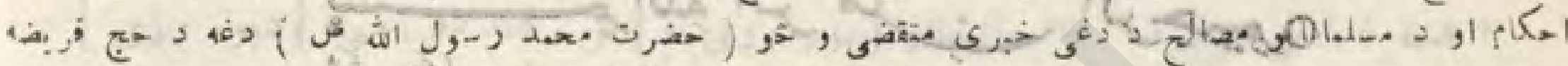

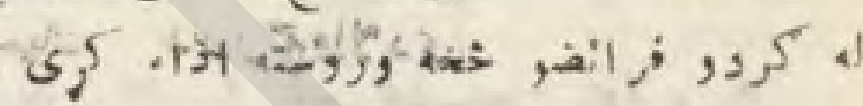

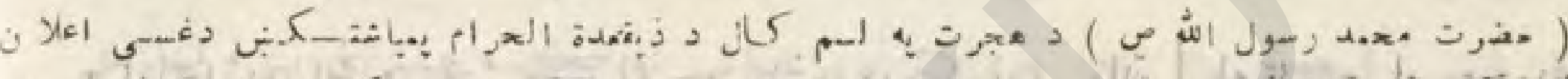

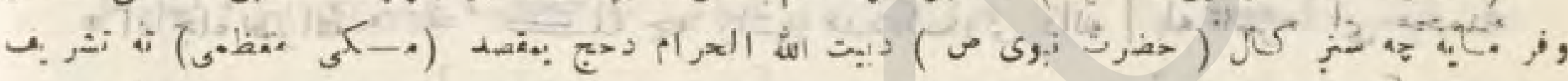

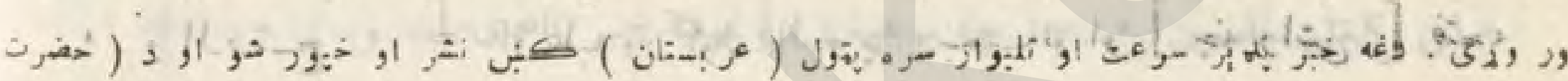

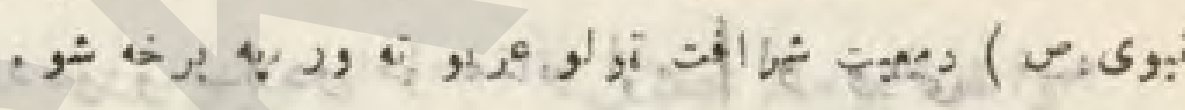

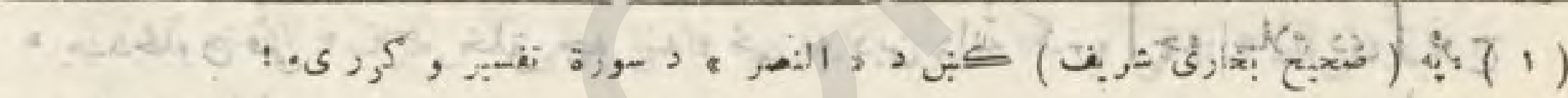

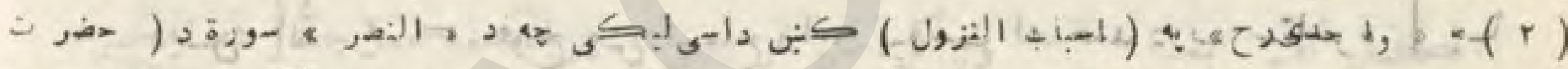

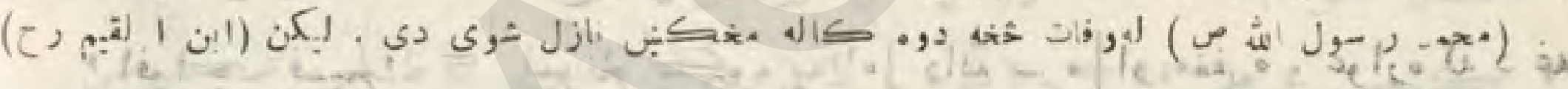

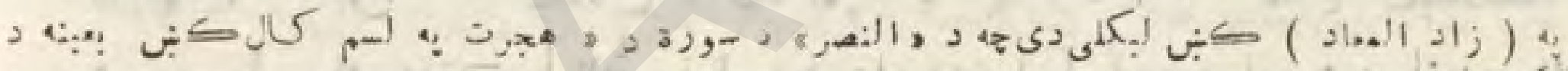

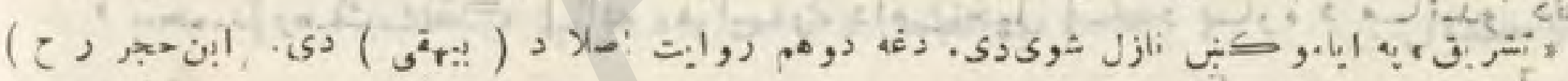

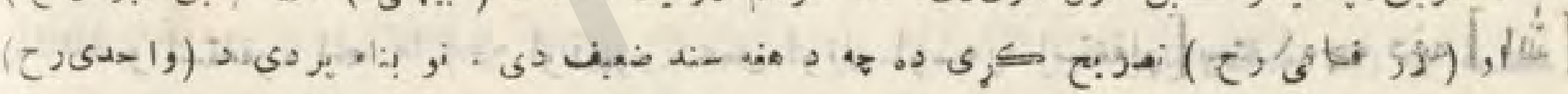
(ح)

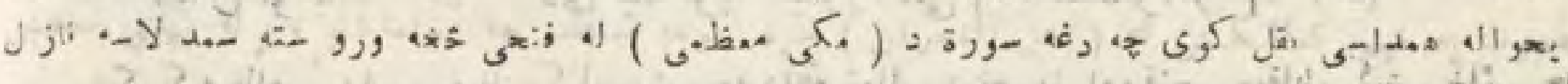
.

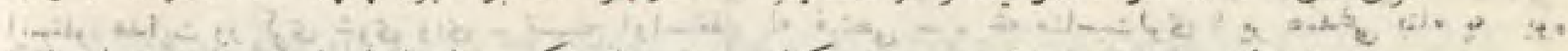

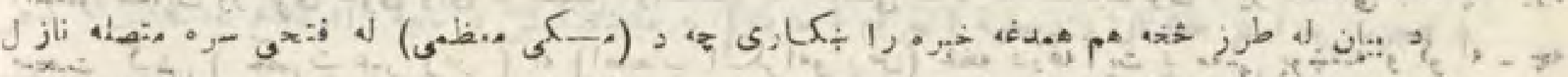

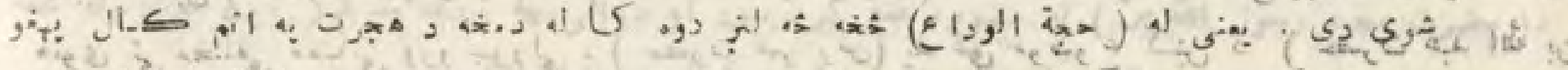

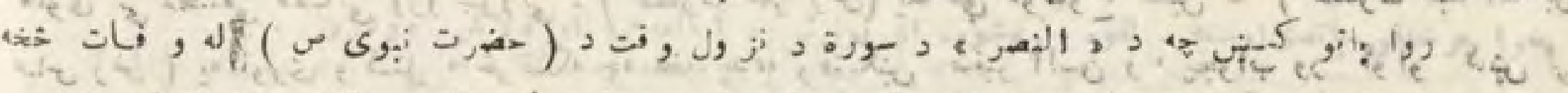

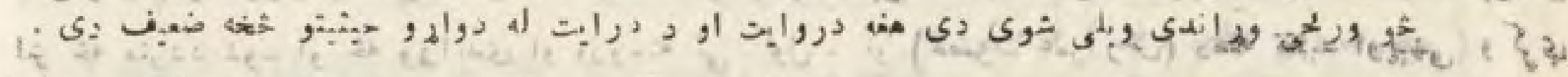

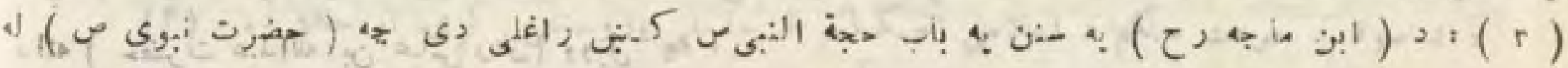

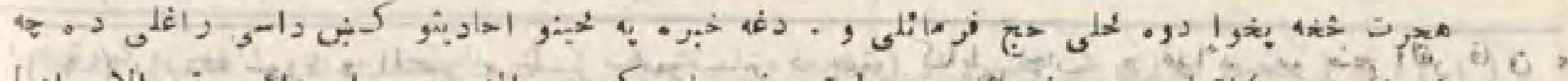

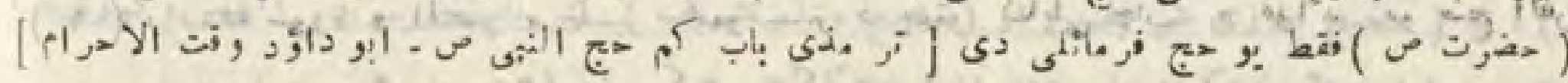
. जग 
s.

$$
\text { - }
$$

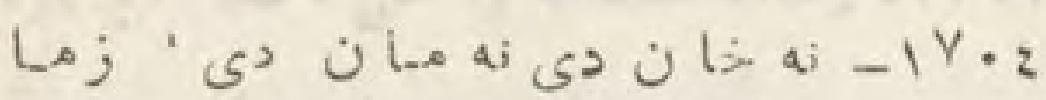

$$
\text { ا }
$$

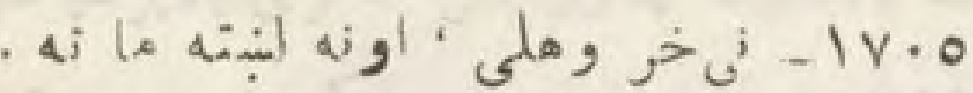
· . :ز

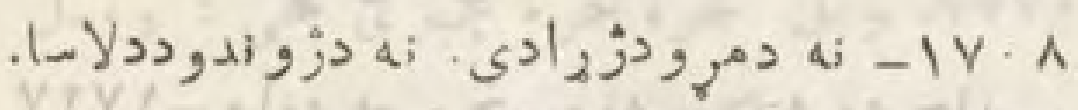

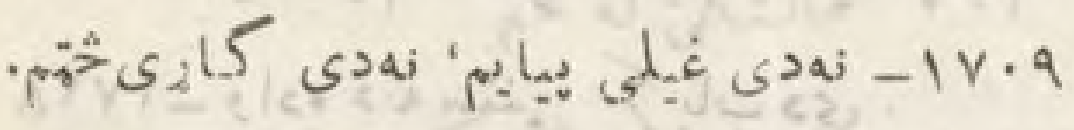
•

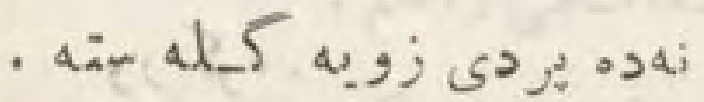

- V II

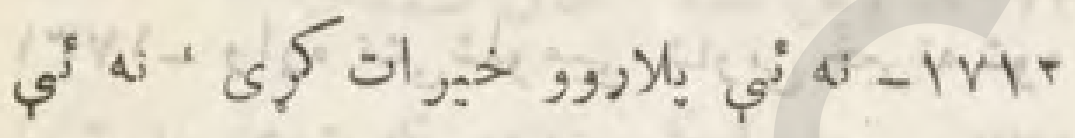

$$
\text { مور ارى و يشلى }
$$

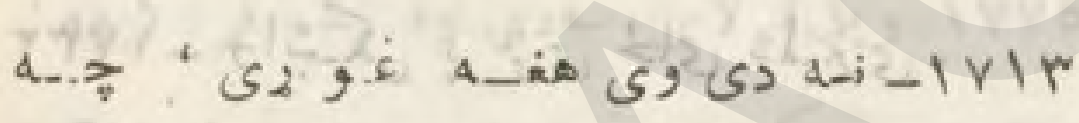
HVI

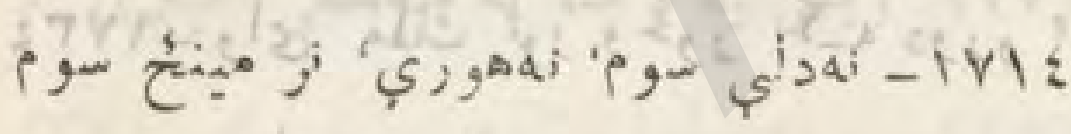

$$
\text { خأورى إئري }
$$

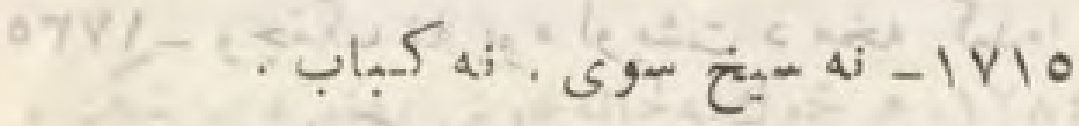

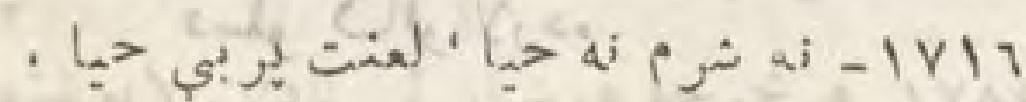

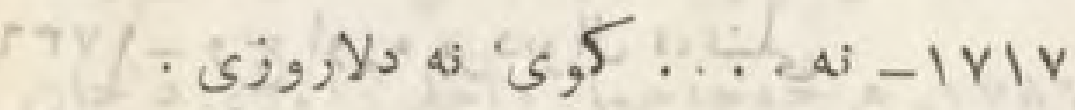
. AV? . . .

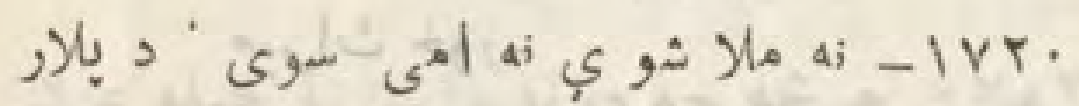
.

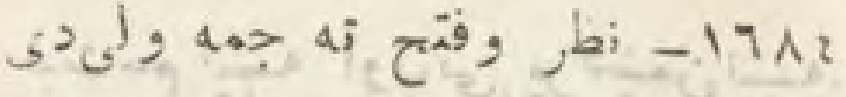

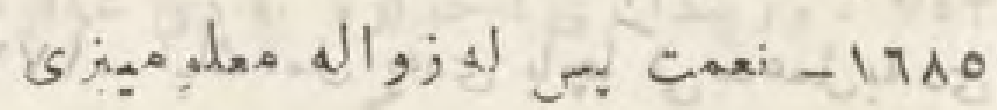
1111 - أعهت

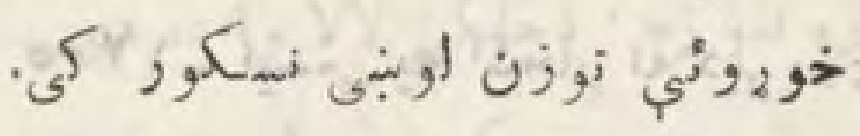

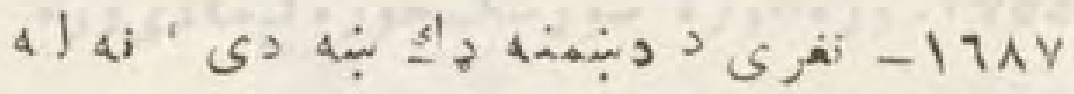

$$
\text { • }
$$

íو

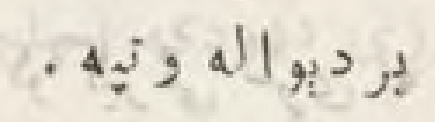

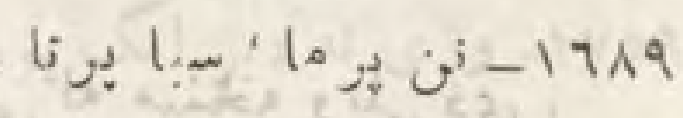

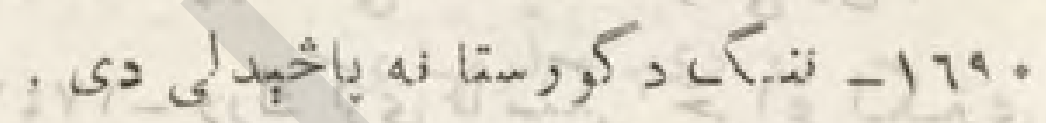

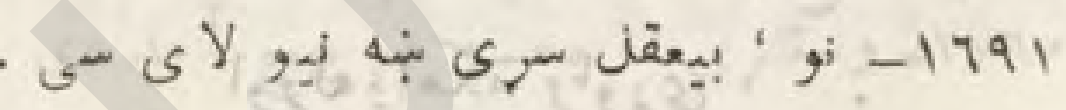

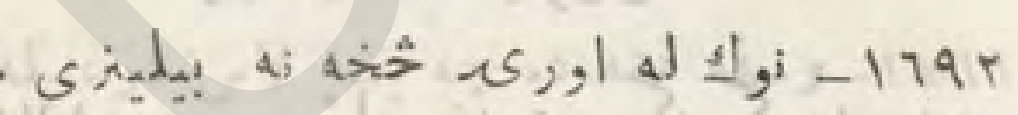
•

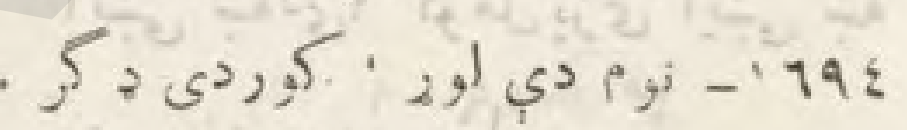

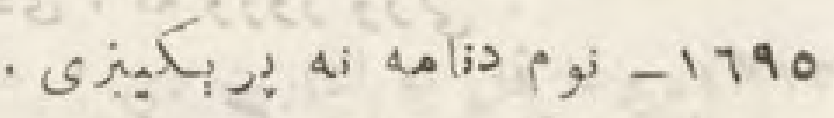

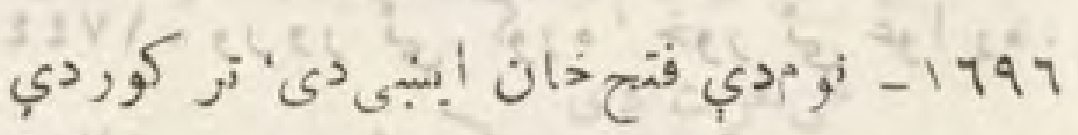

$$
\text { . }
$$

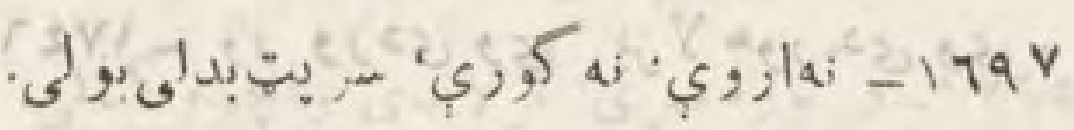

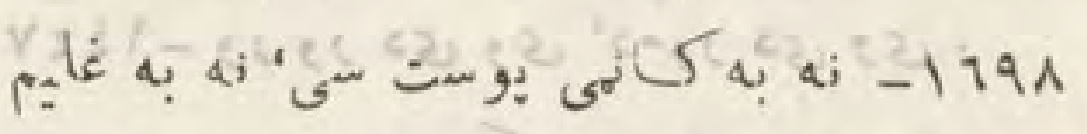

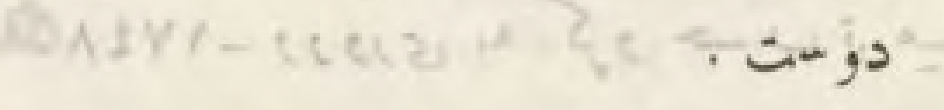
ئ i s a al_

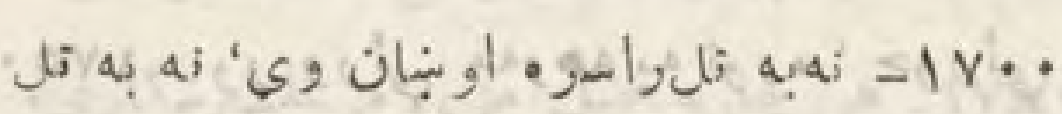

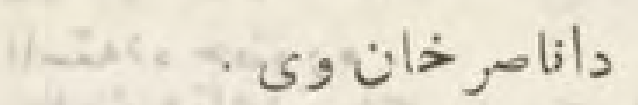

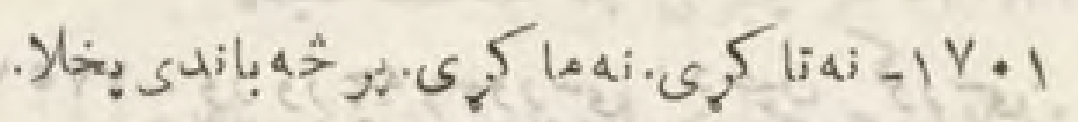

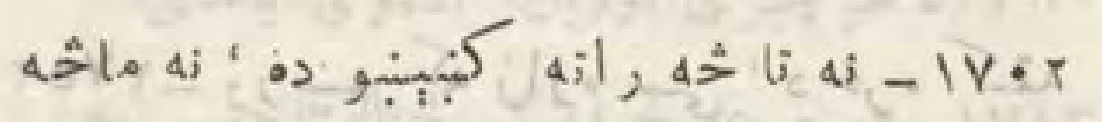

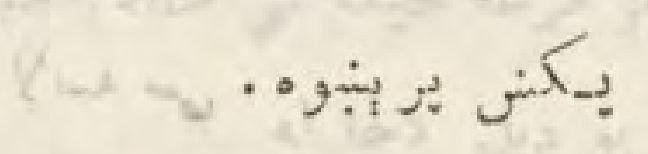


年

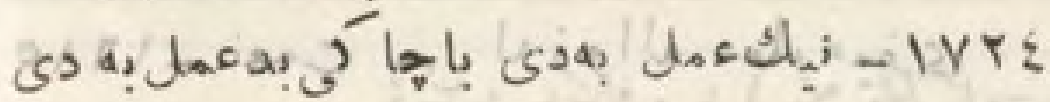

$$
\begin{aligned}
& \text { st, }
\end{aligned}
$$

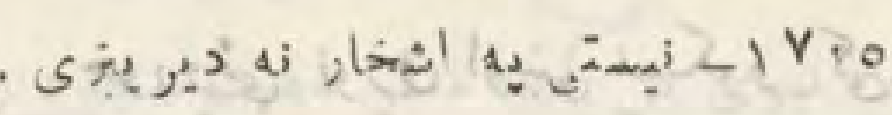$$
\text { Con og }
$$

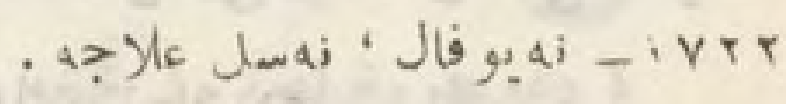

\section{9}

أ

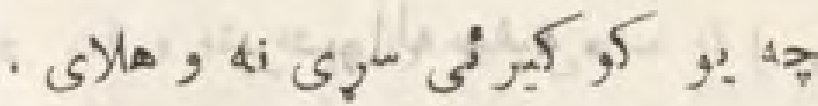

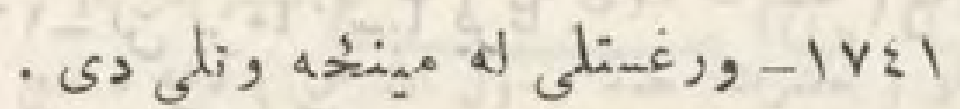

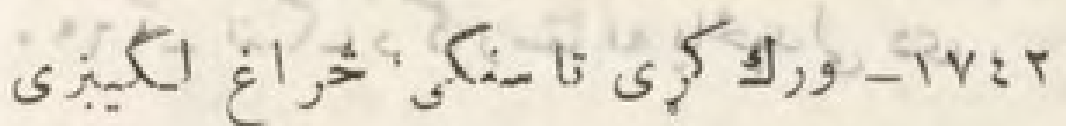

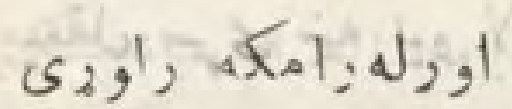

ك اينبى بنه

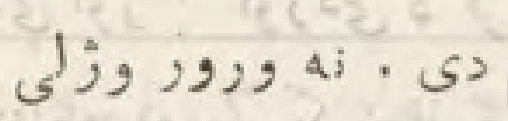

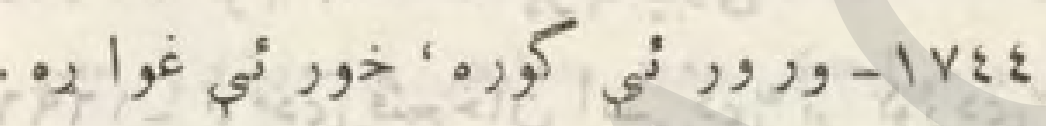

$$
\text { iv }
$$

.

$$
\text { . }
$$$$
\text { 1V々1 }
$$

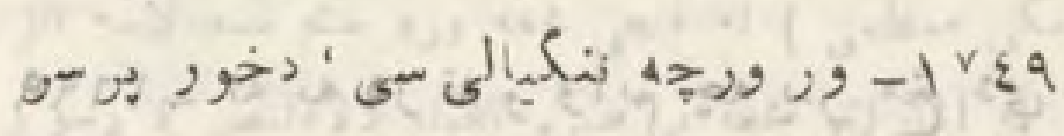

$$
\text { . }
$$

.

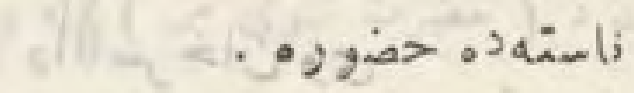

كورسن .

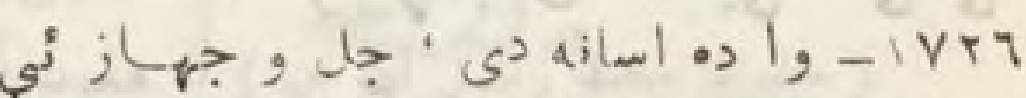
ज 15

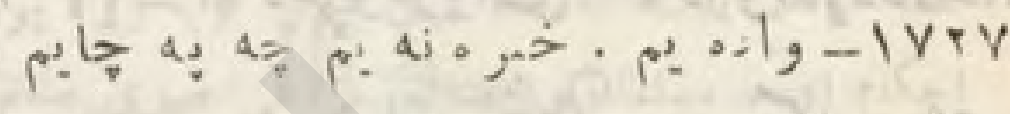

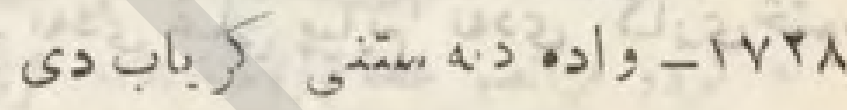

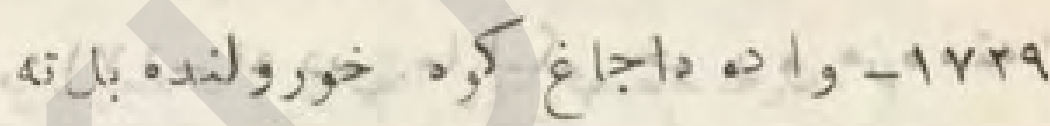
.

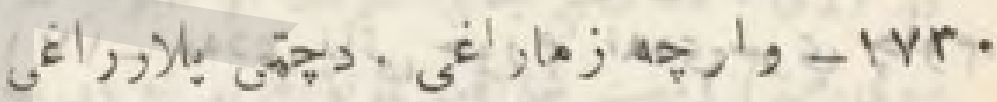

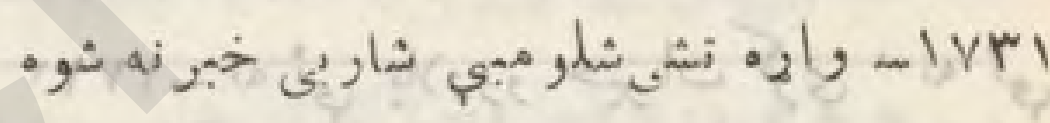
anles al

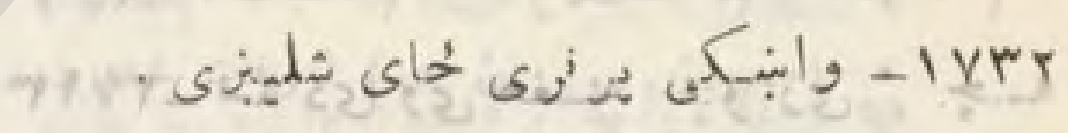

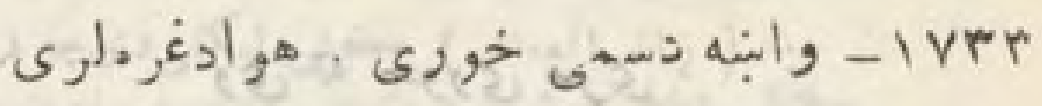
?

$$
\text { واى دورواى }
$$

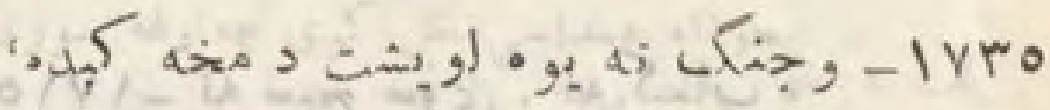

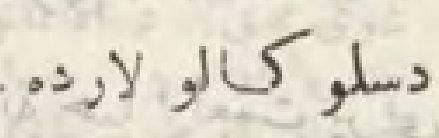

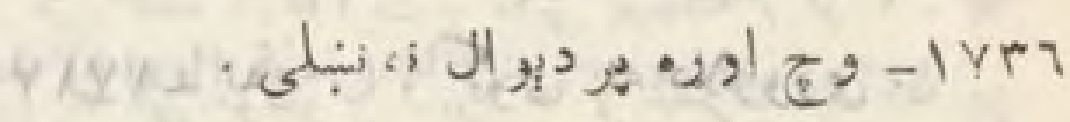
每 (v) so a

$$
\text { ميراث خورن }
$$

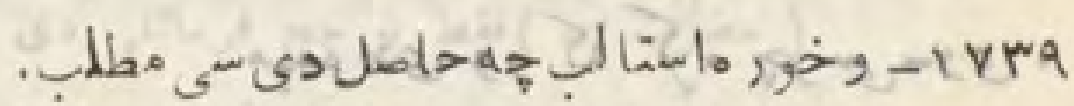


$01)$

ज जि

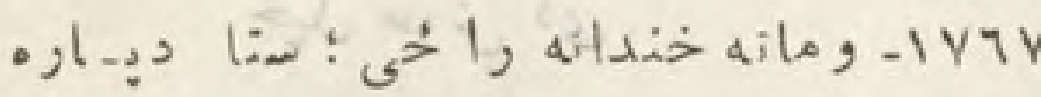

4. as $4 A$

4i $0 \hat{x}$

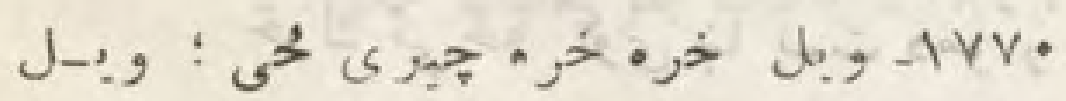
ماله

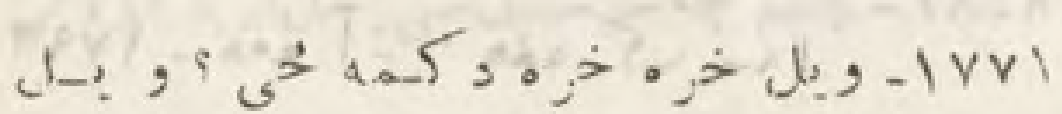

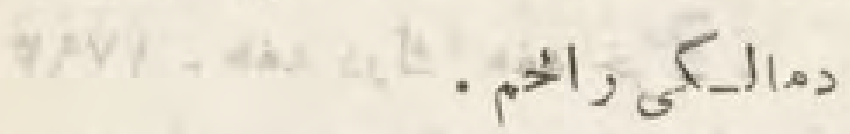

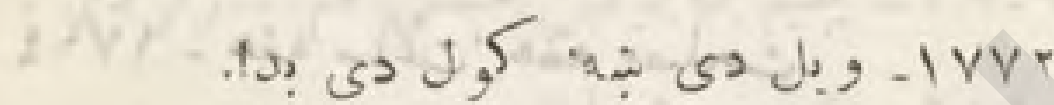

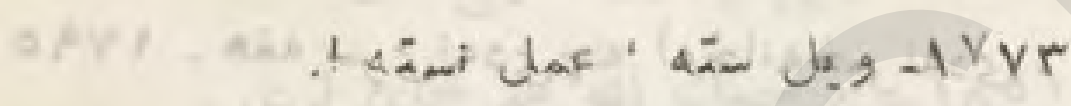
.

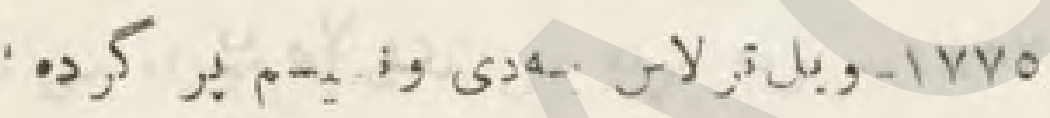

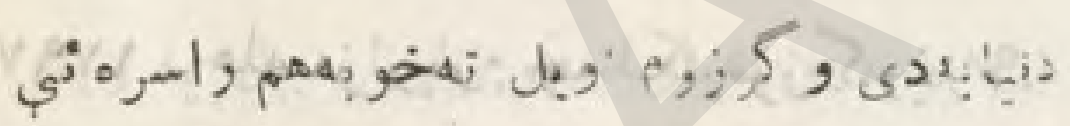

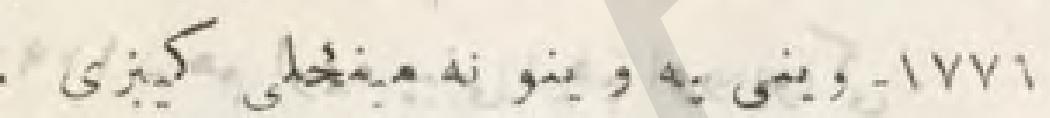

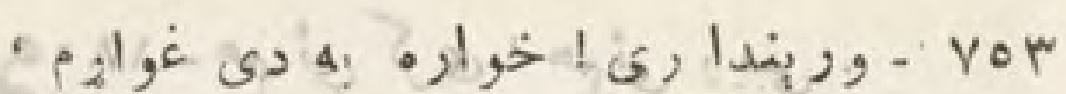
5 , ر. 29290

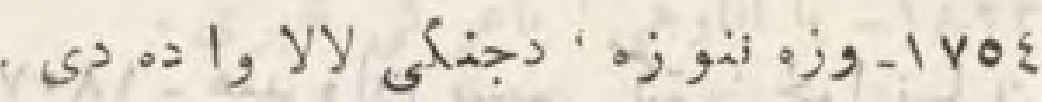

• voo

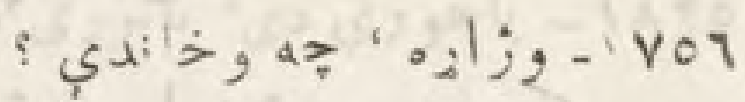
v vov

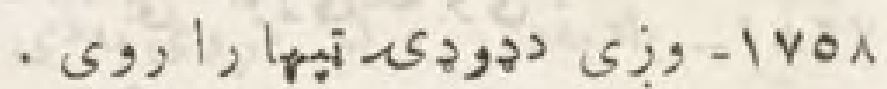

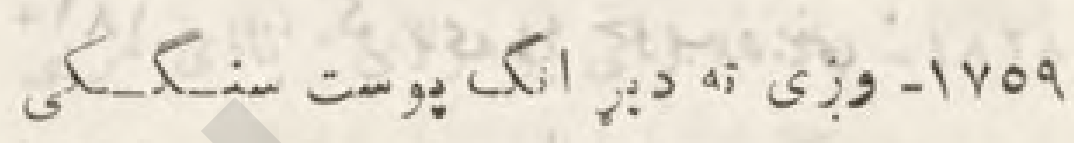

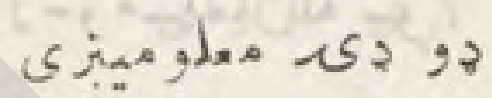

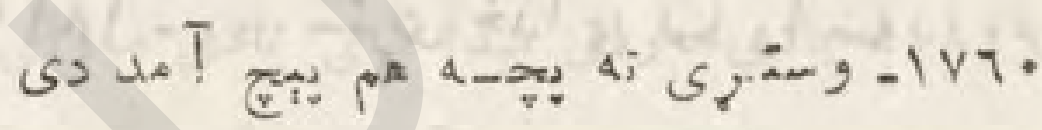
. . C, , $\Rightarrow 0,54$

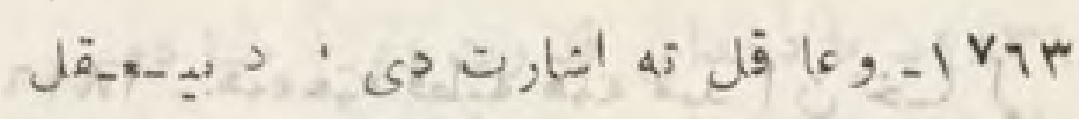
ي مئفرت $\therefore,>, j, 0.5,-1 \times 42$

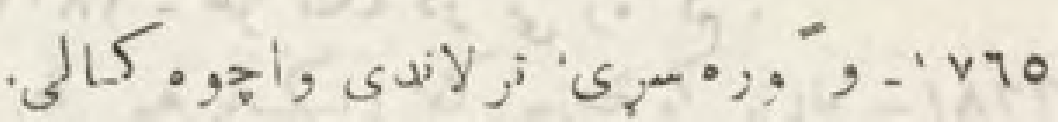

$\$$

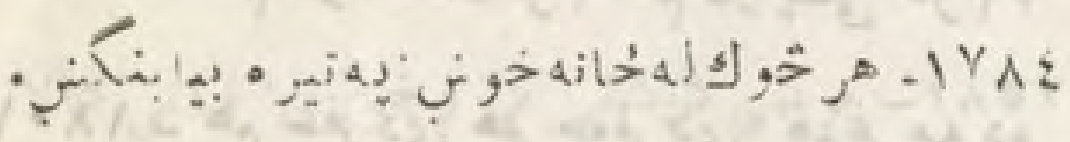

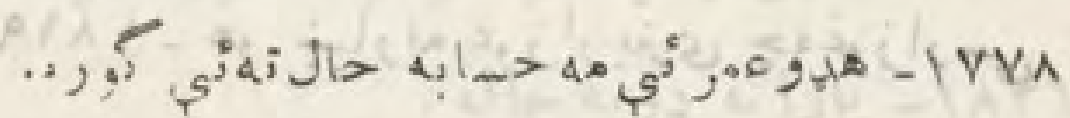

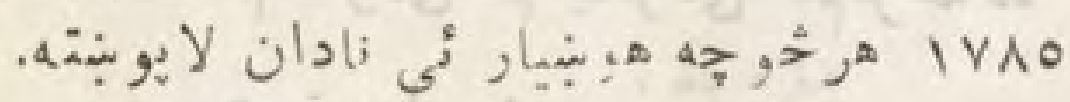

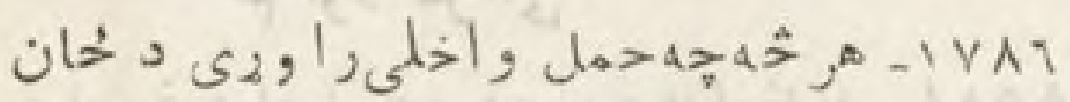

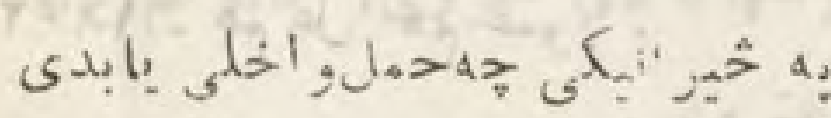

$$
\text { jo l. } \mathrm{s}_{2}, 1 \text {, }
$$

ك

$$
\text { ن بـ }
$$

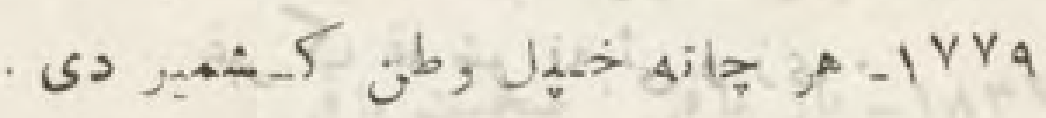
.

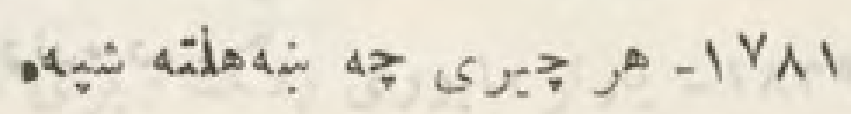

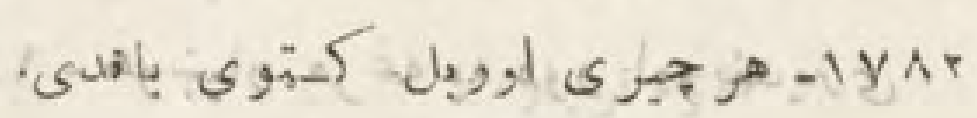
vasi at $\gg$ و و و 
Aor 0

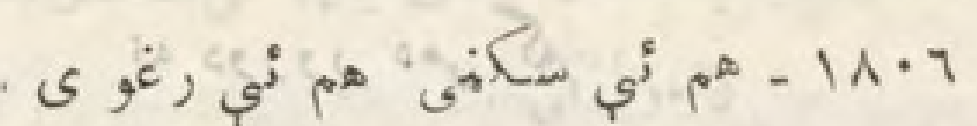

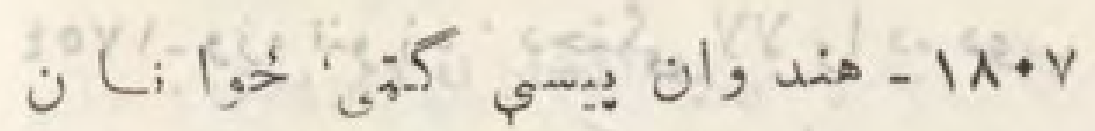

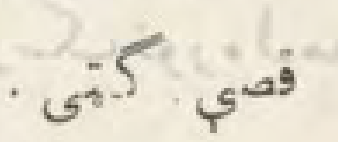

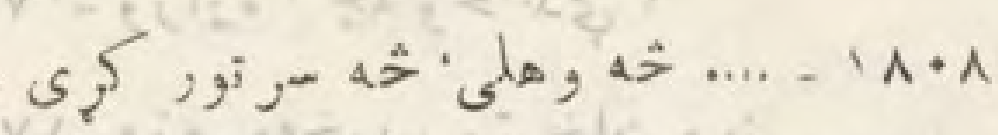

. ज, ب. . 11.9. ،

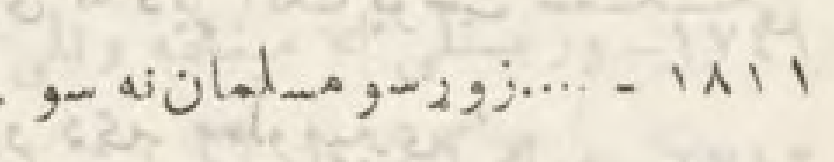

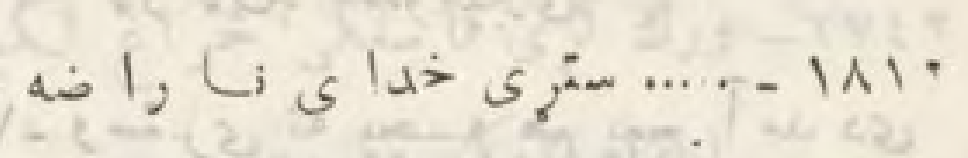

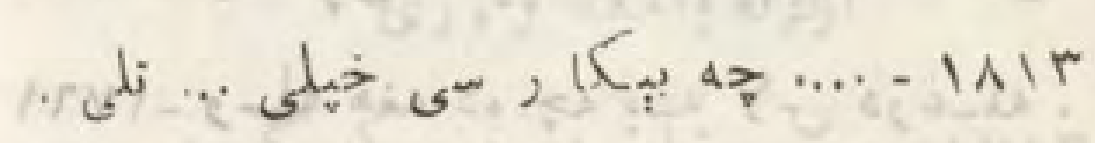

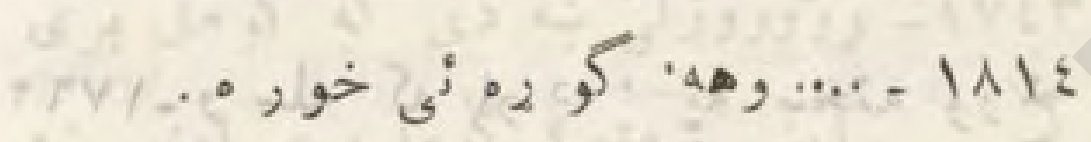

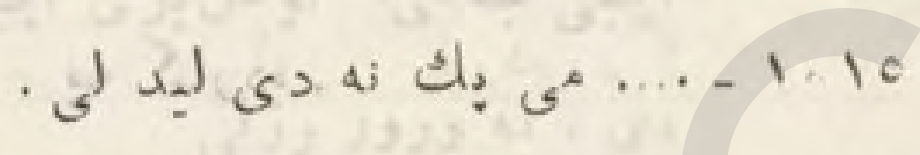
J

$$
\begin{aligned}
& \text { - ais suil vilg }
\end{aligned}
$$

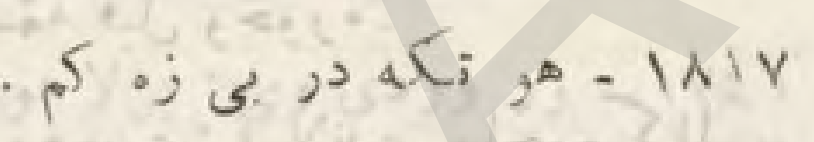

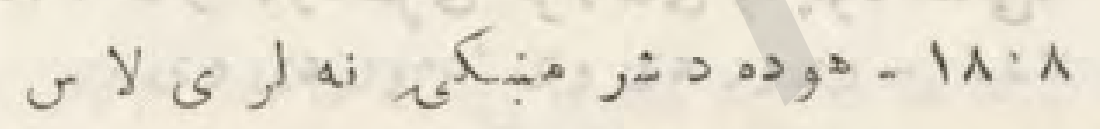

$$
\text { s }
$$

(

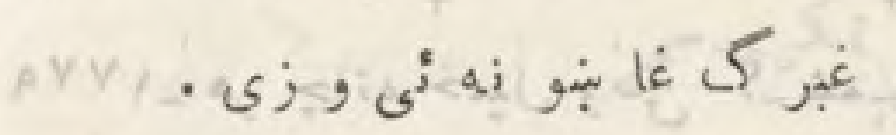

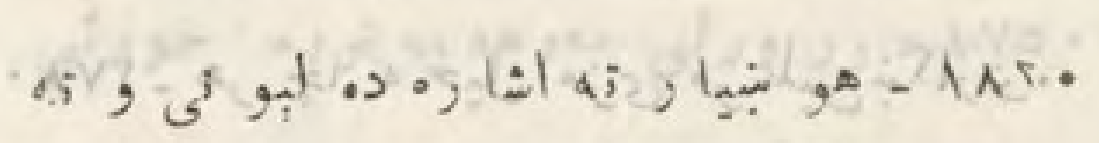

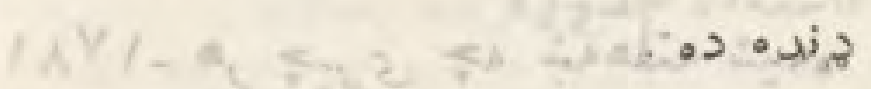

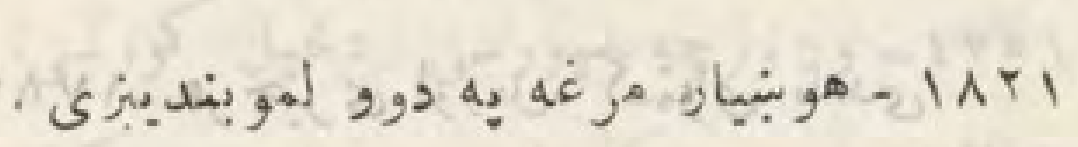
7 ك

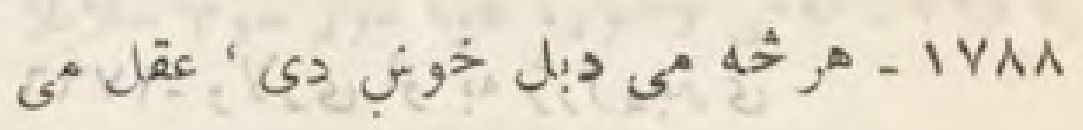

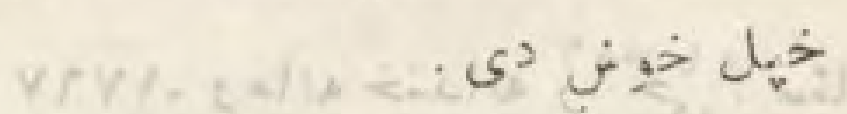

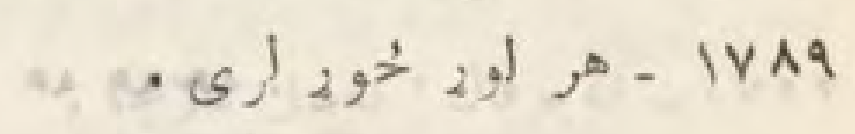

ul

$$
\text { ai } 1 ;, 13,9 \text { : }
$$

vوai- 4 in خو كأ

$$
\text { , }
$$

lan Co aid it ais - IVat

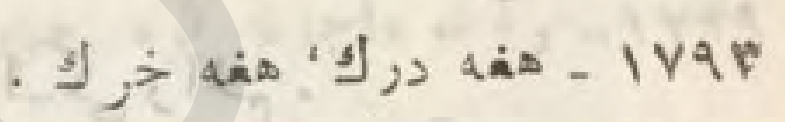

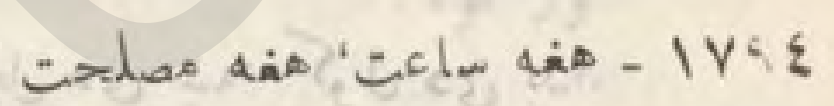

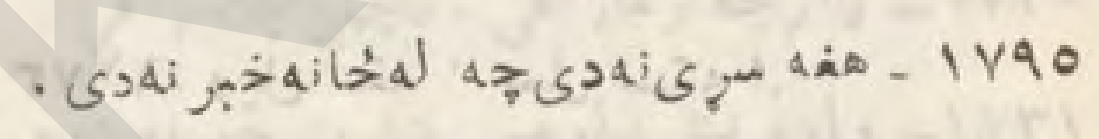

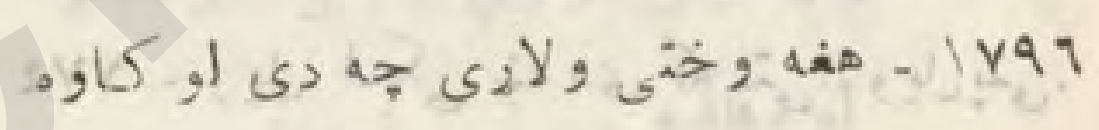

$$
v_{2} y_{2}, 4
$$

.ejo, vVV.

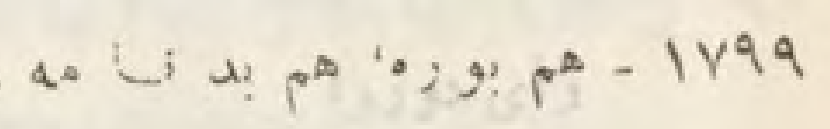

ه

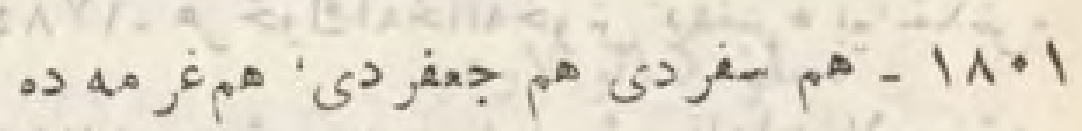

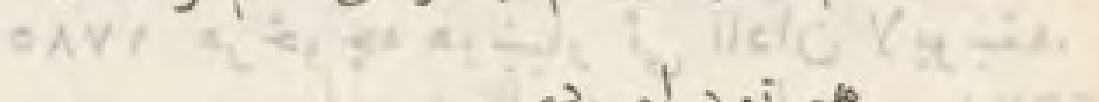
$\cdot v^{3} \pi^{2}>g^{20}$

$$
\text { - jacke cle }
$$

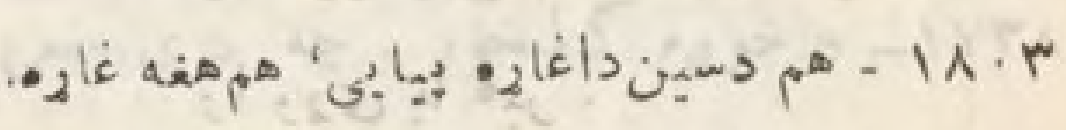

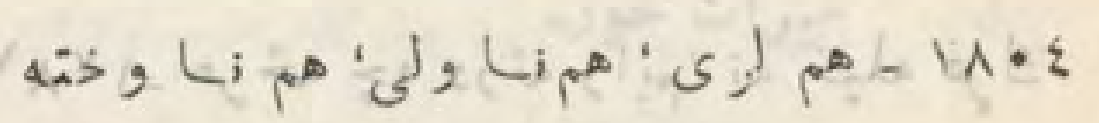

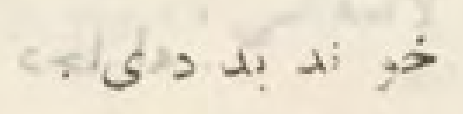




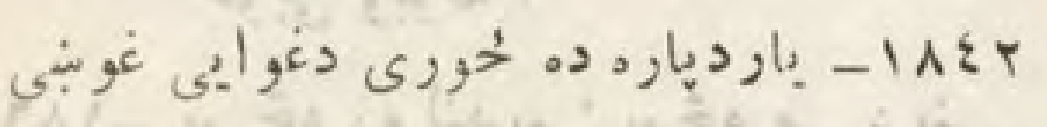

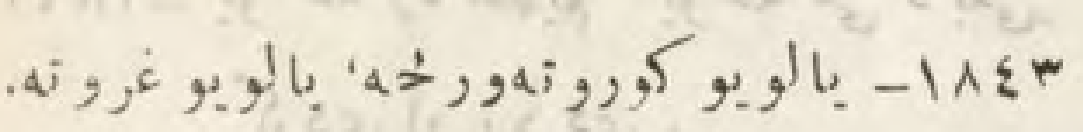

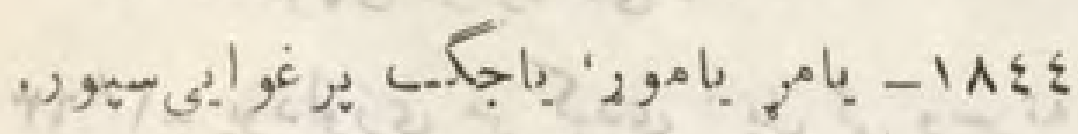
ى

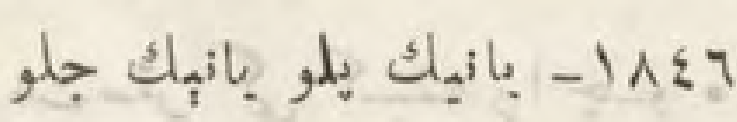

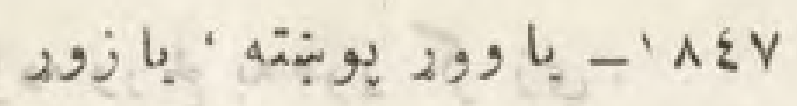

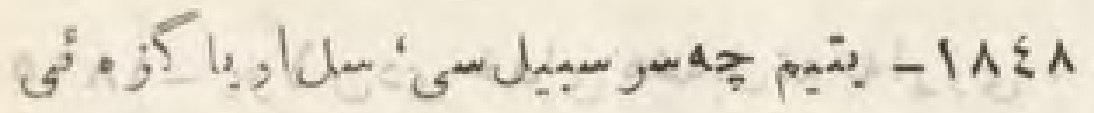

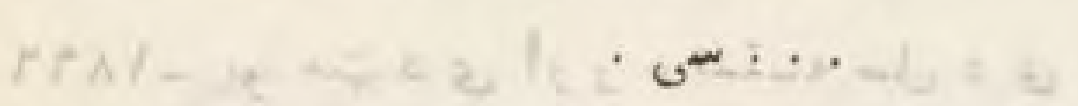

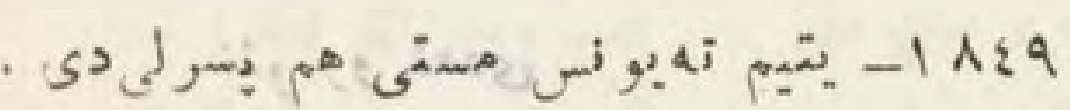

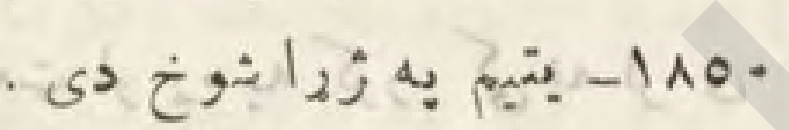

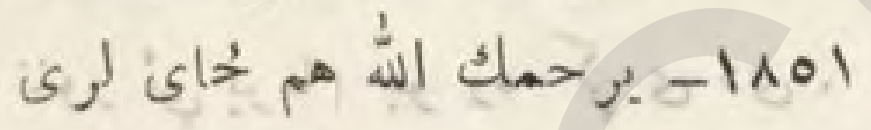

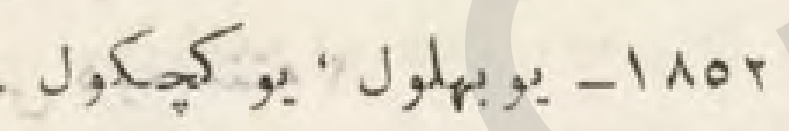

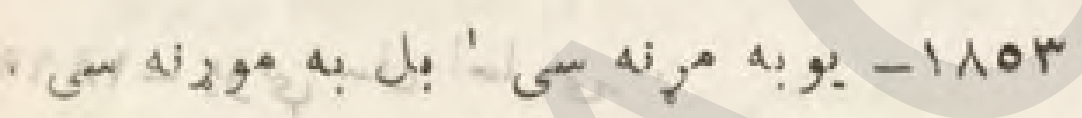

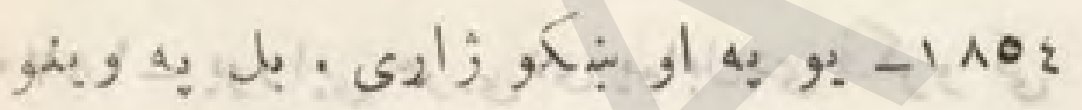

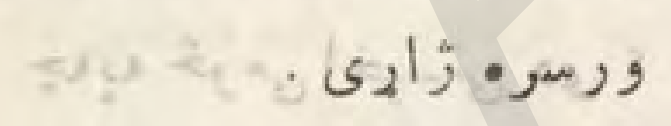

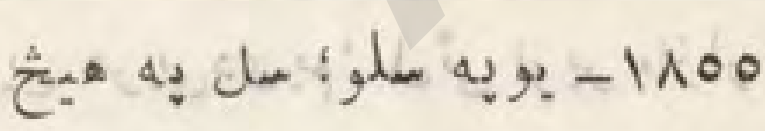

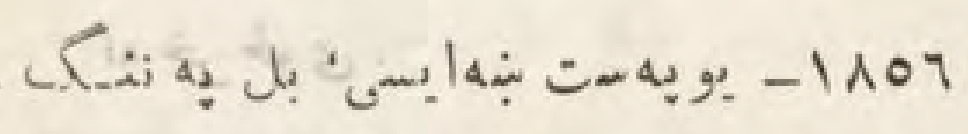
110V

$$
\text { - ob ojo }
$$

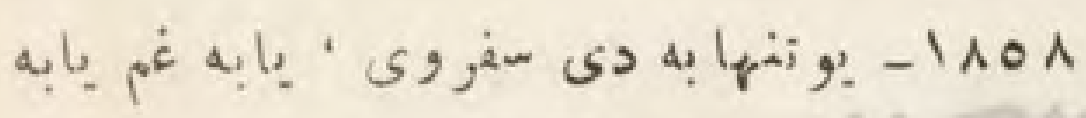

$$
\text { ا }
$$

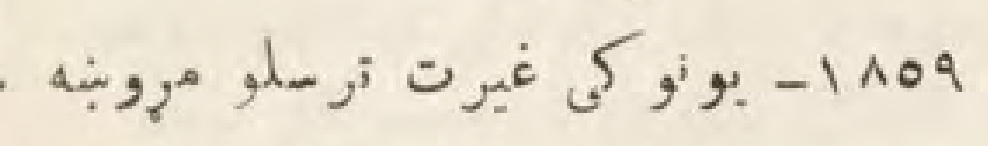

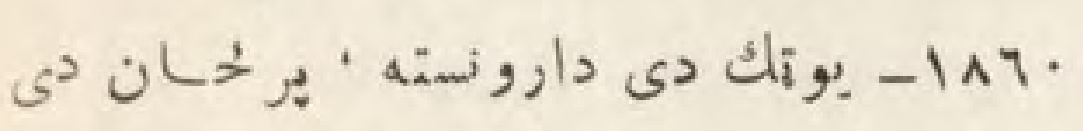

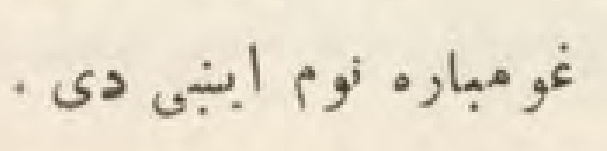

年

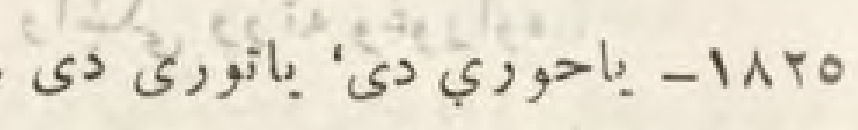
A

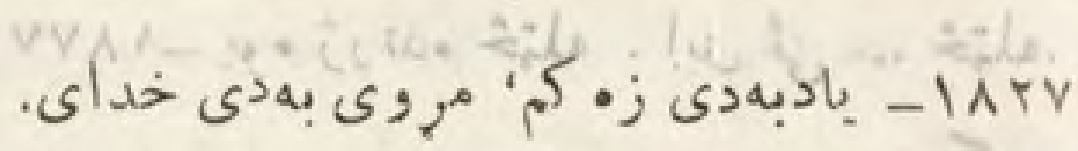

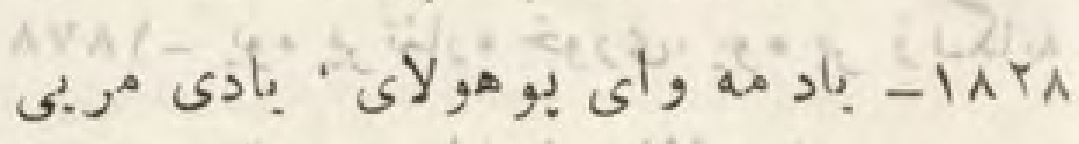

$$
\text { जो }
$$

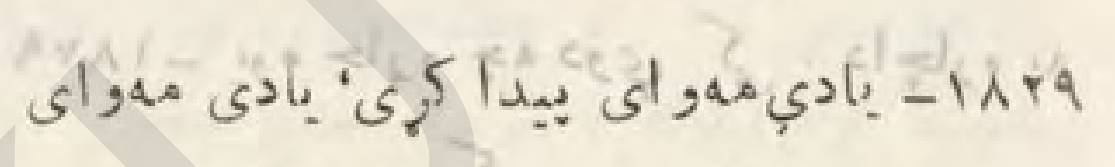

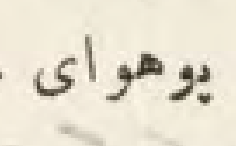

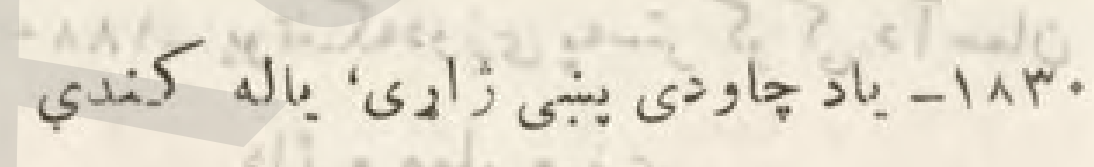

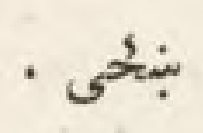

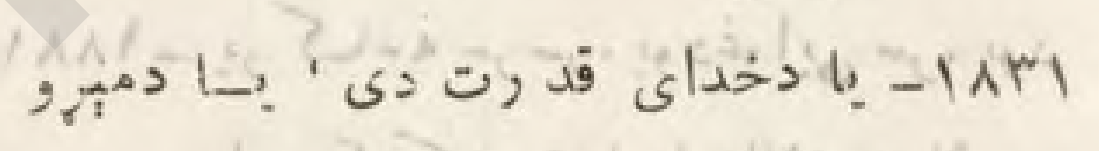

$$
\text { v ع }
$$

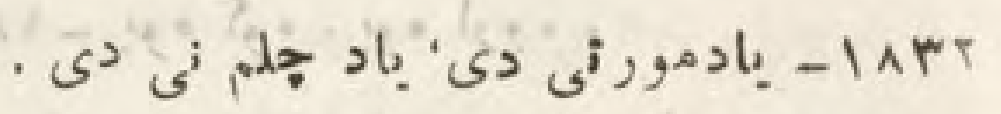 .

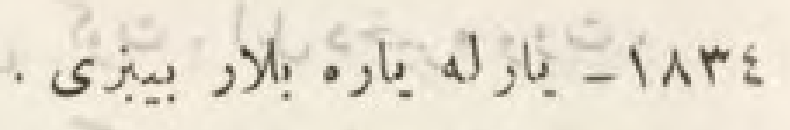

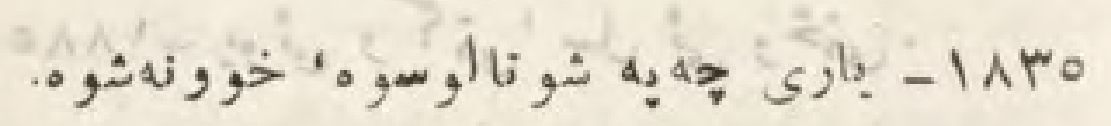

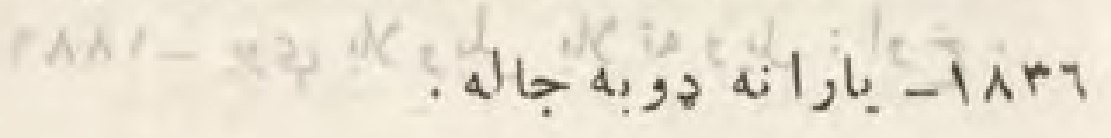
ل

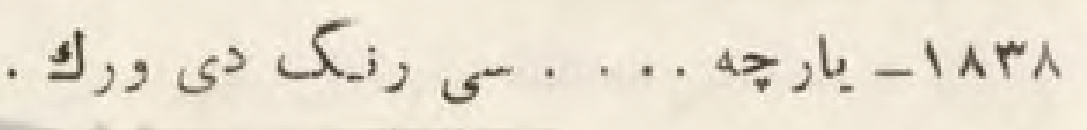

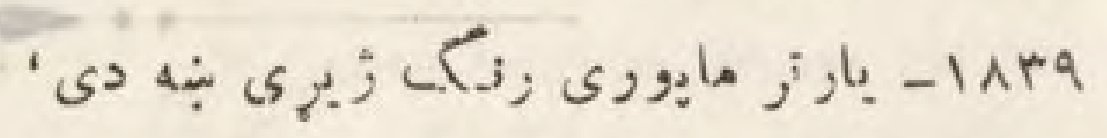

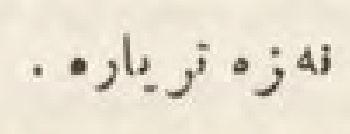

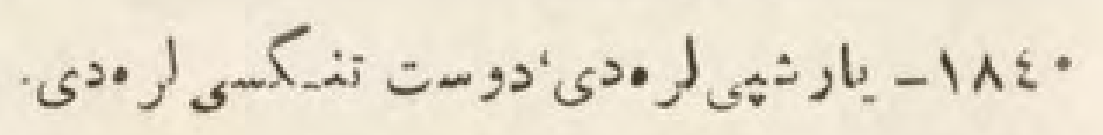

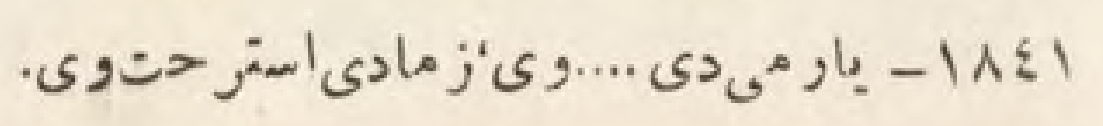


ا I یVP 罗

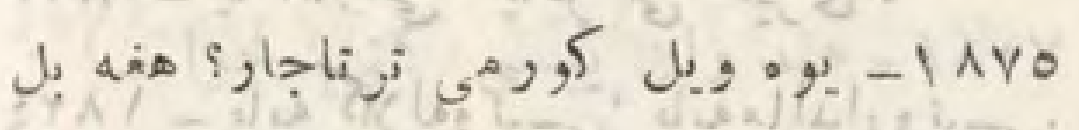
. ol

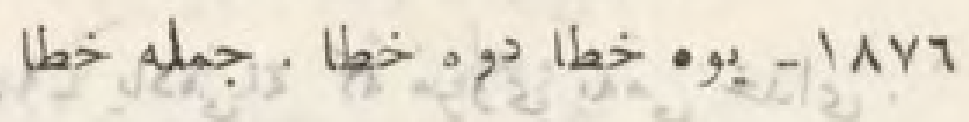
.

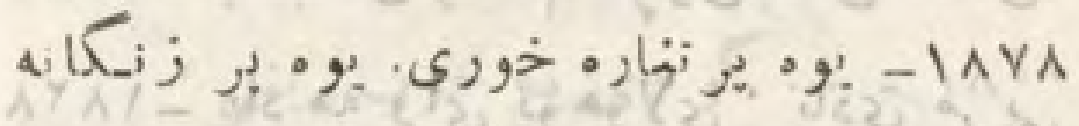
ن

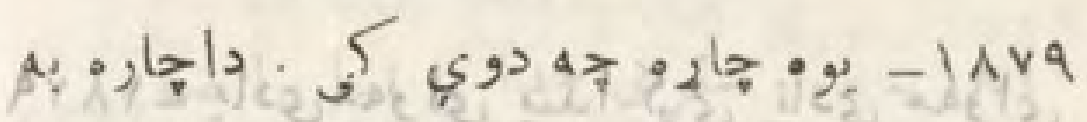
5 ك 5

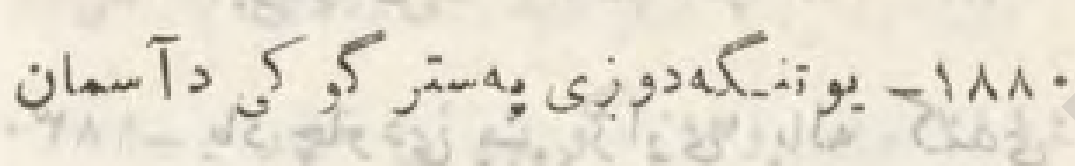

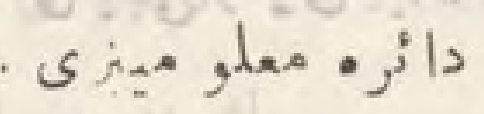

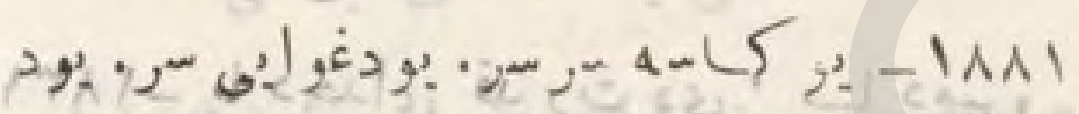

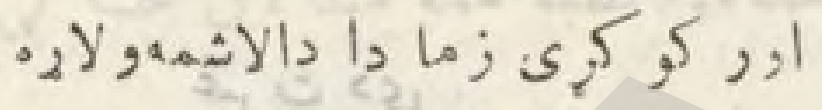

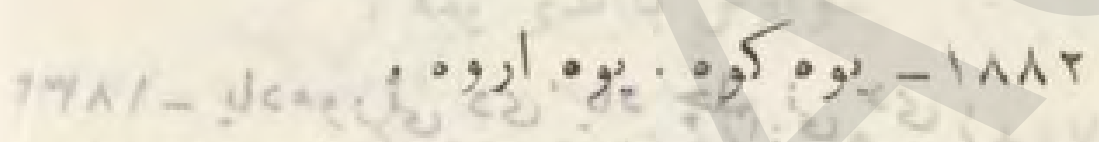

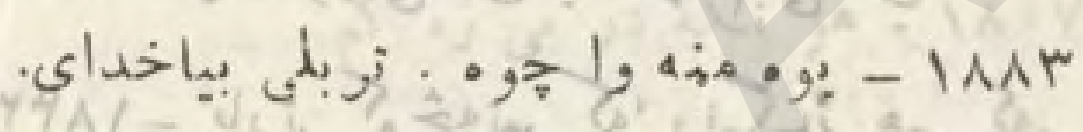

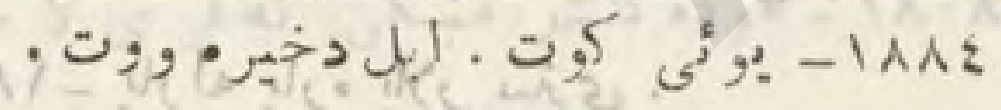
أخ
ك

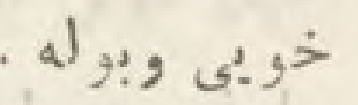

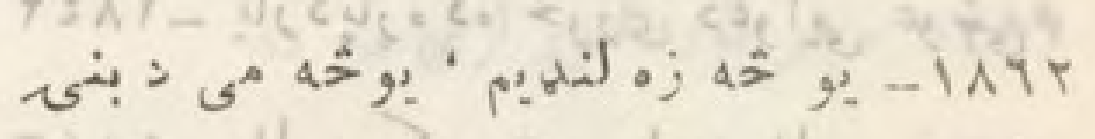

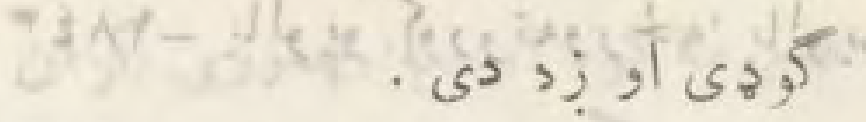

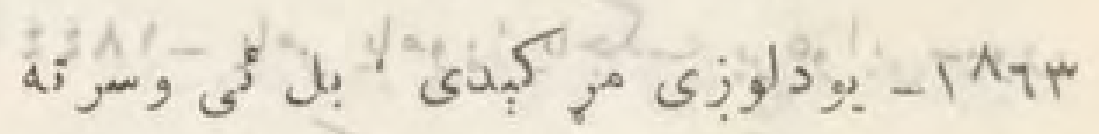

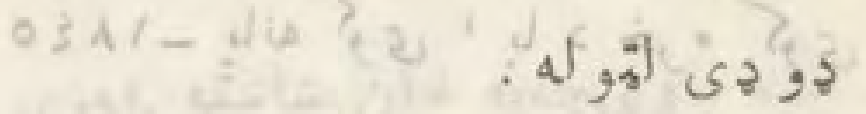

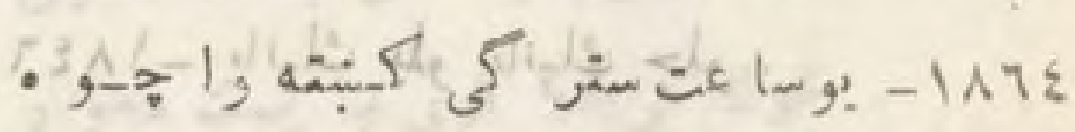
$v+x$ -

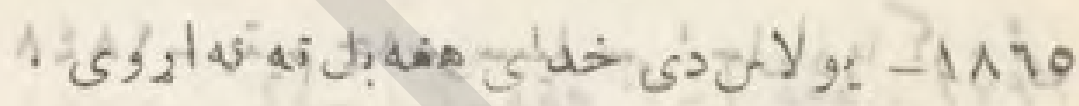

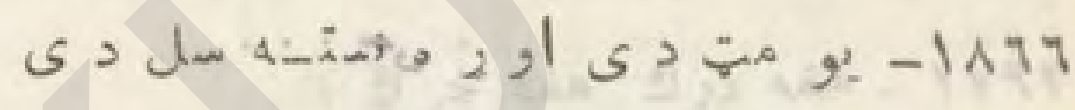

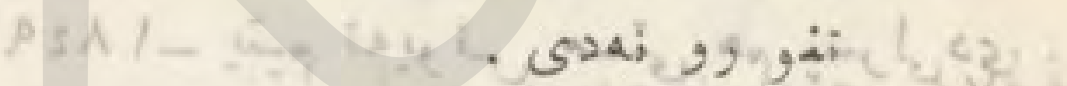

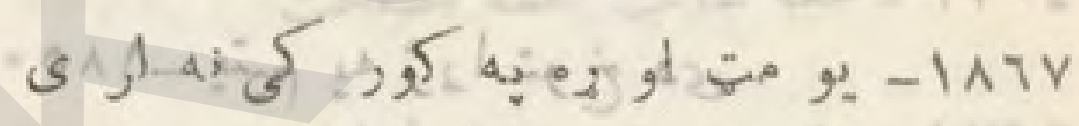
تصور كي

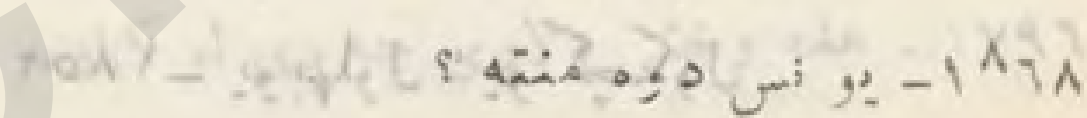

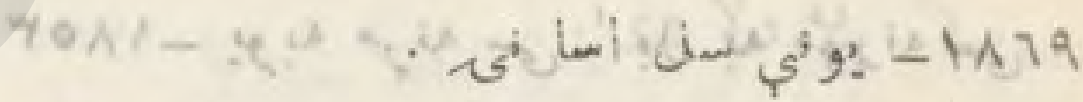

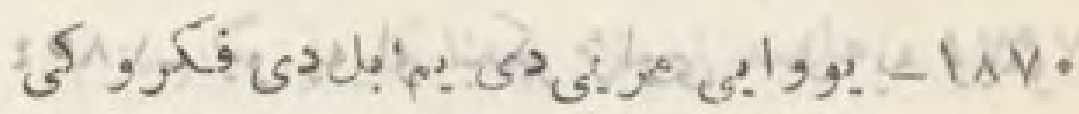

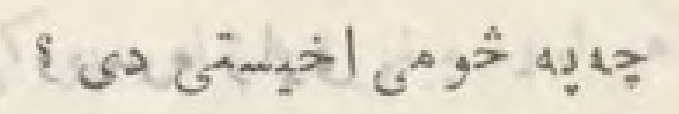

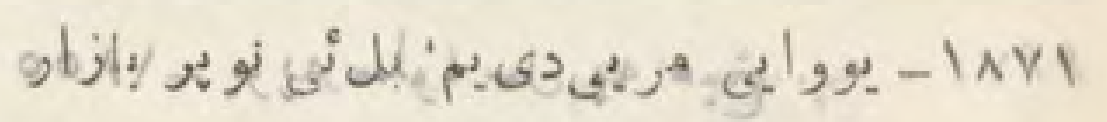

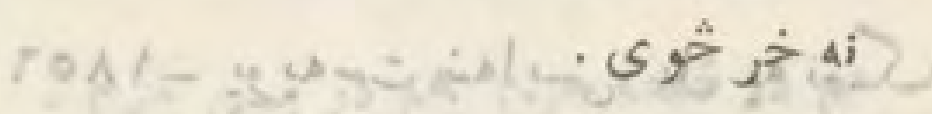

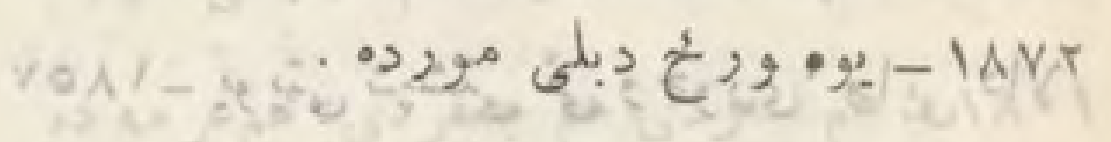

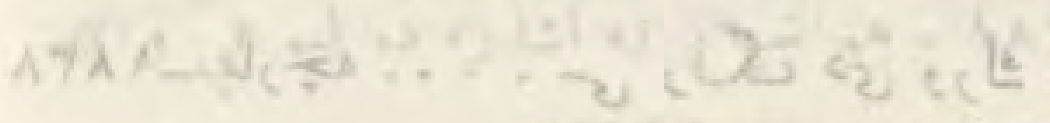




\section{كتابو زك}

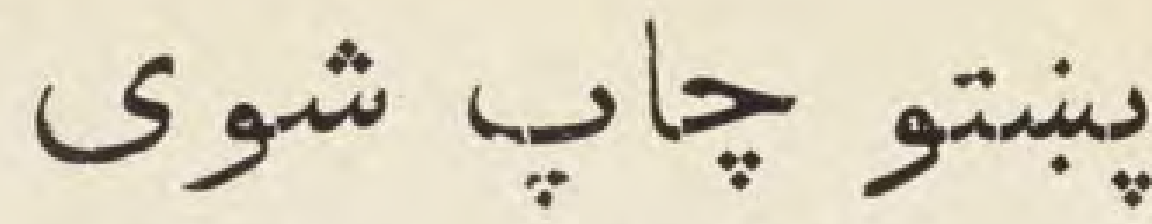

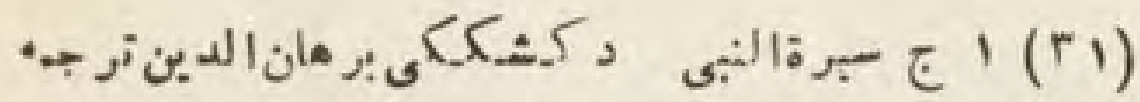

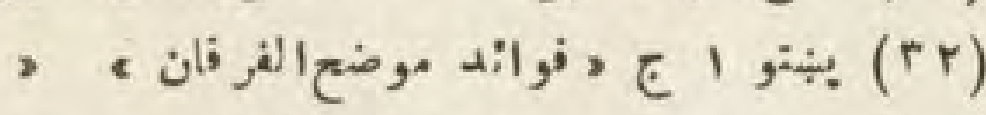

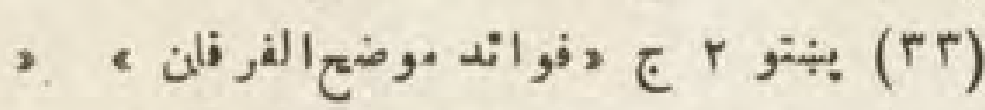

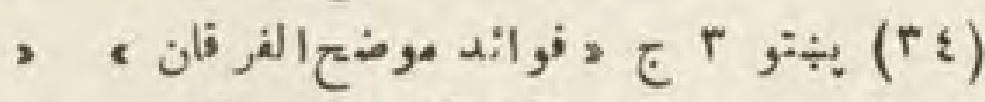

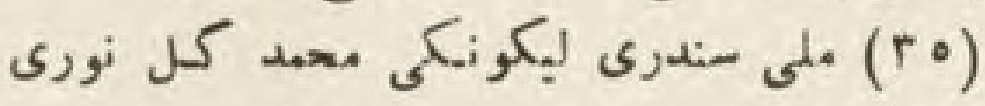

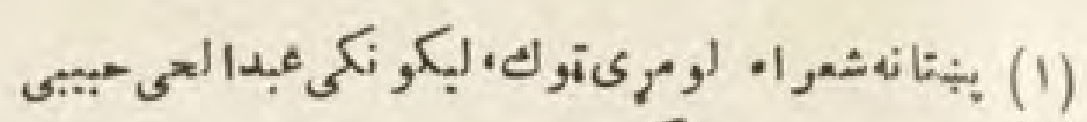

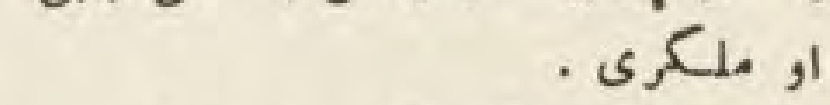

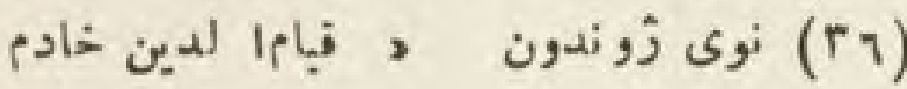

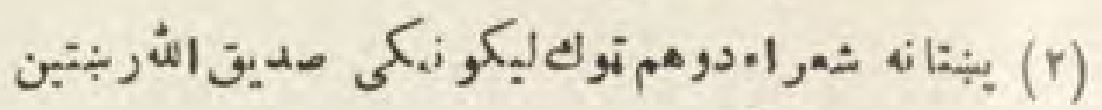

(rv)

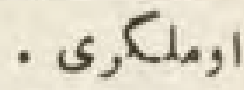

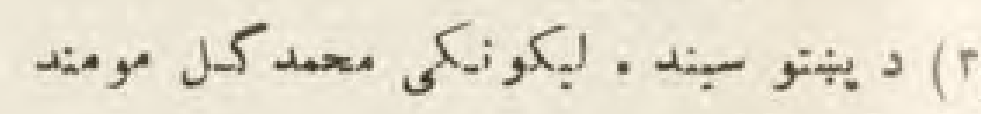

(rA)

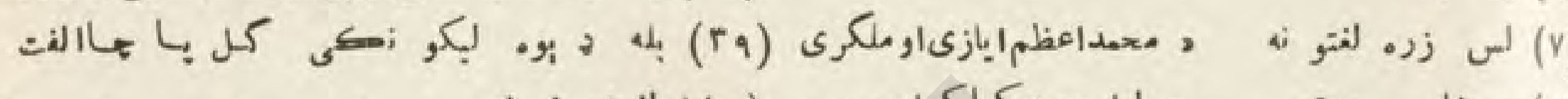

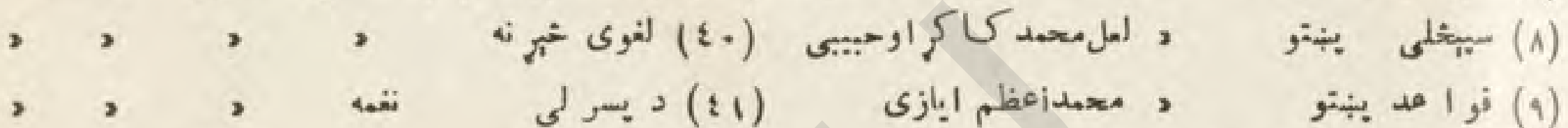

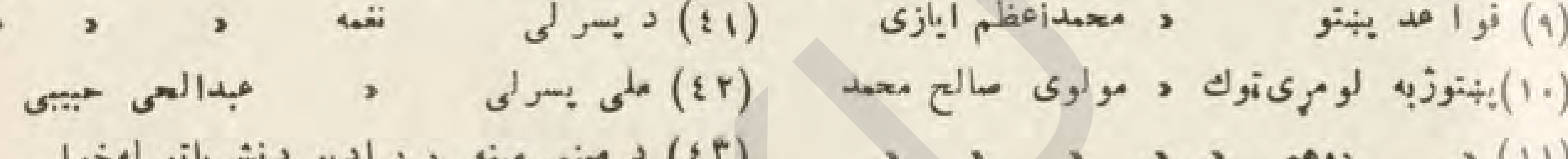

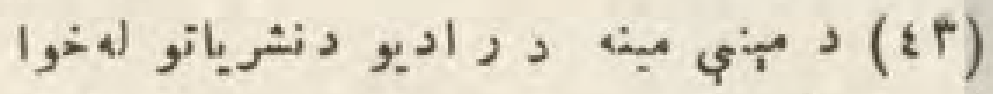

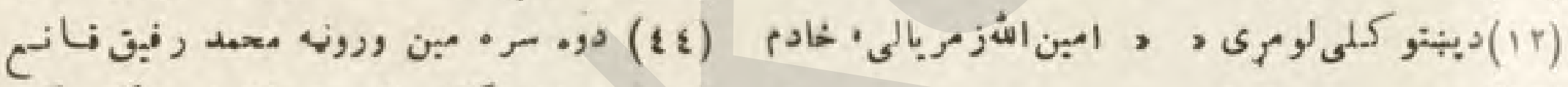

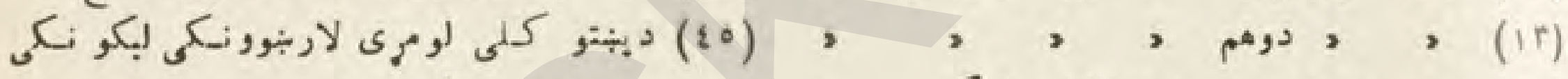

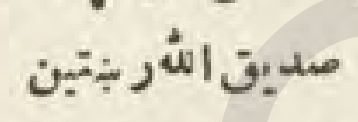

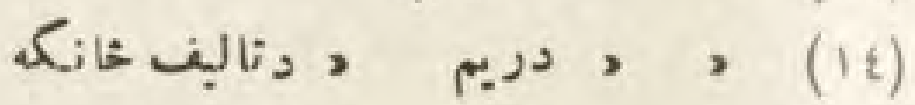

(

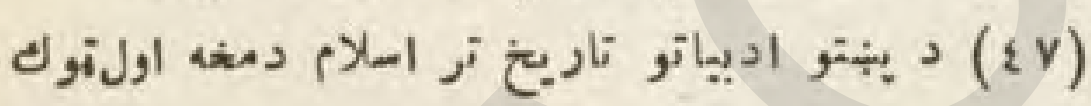

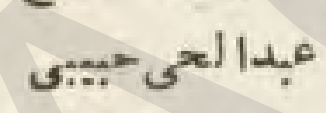

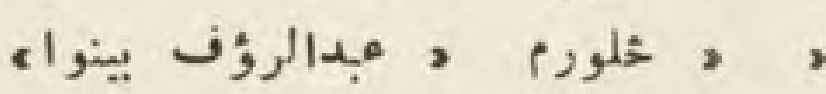

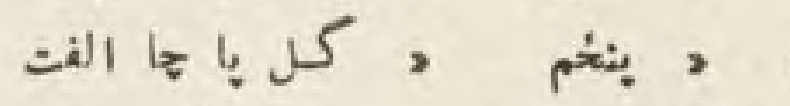

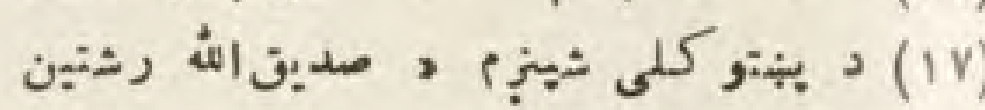

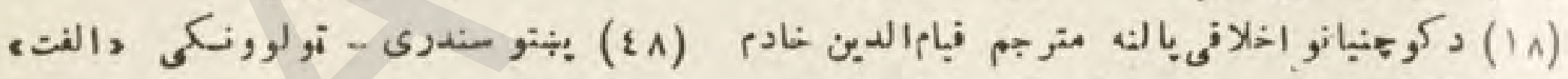

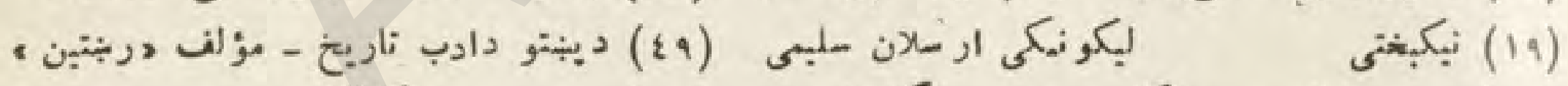

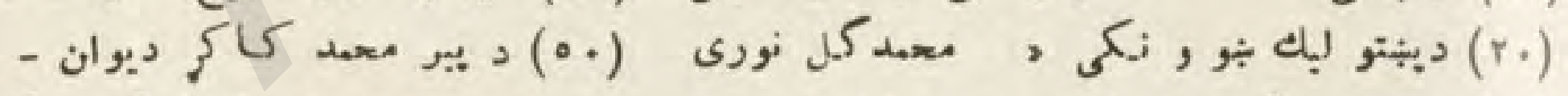

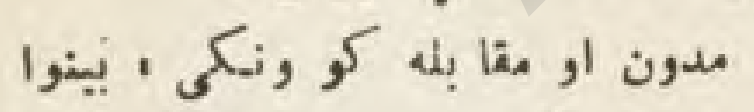

(ril)

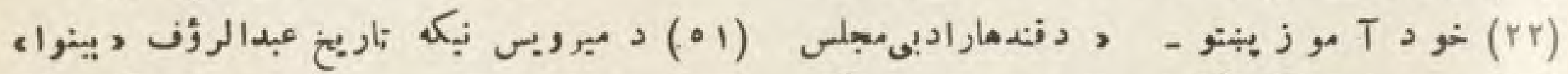
(Yr)

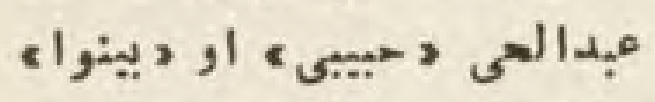

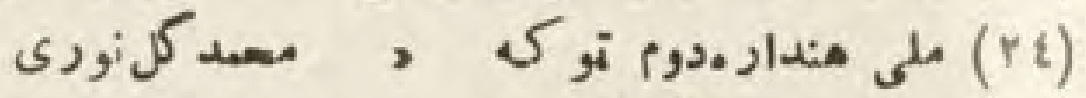

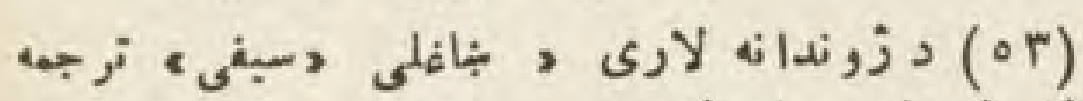

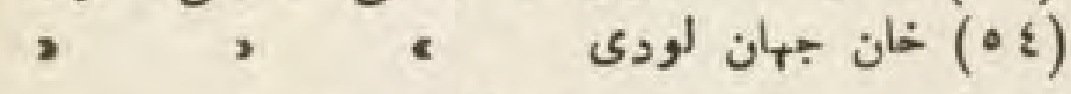

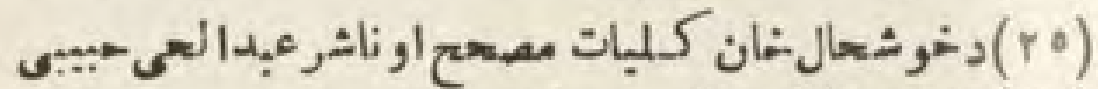

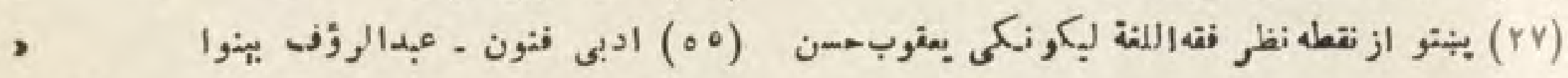

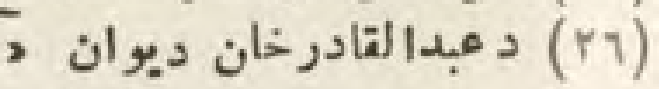

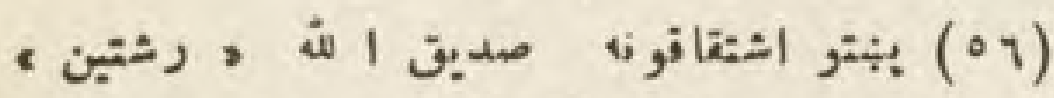

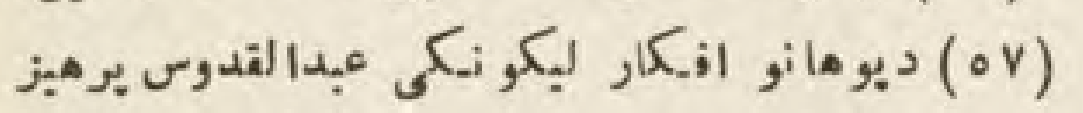

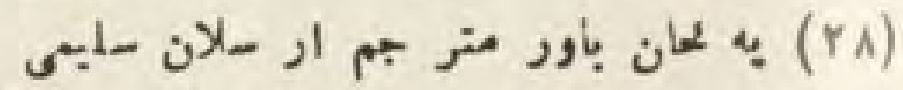

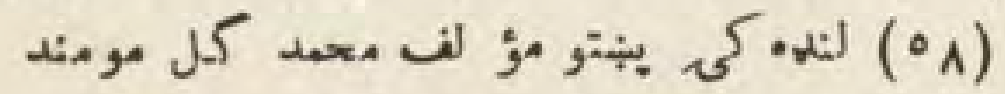

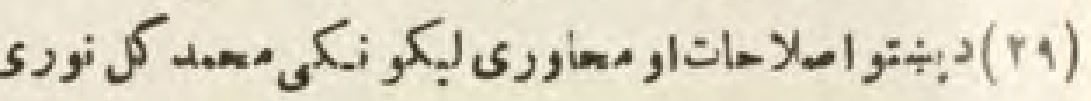

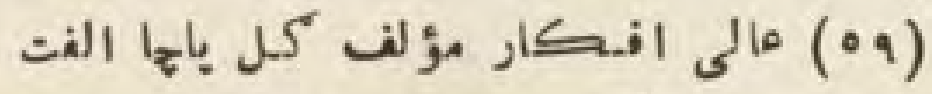

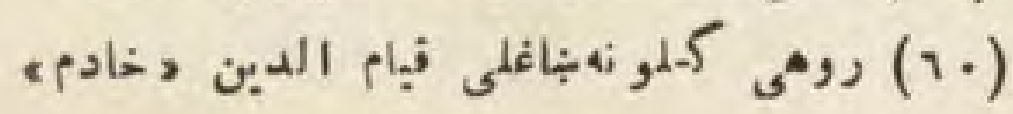




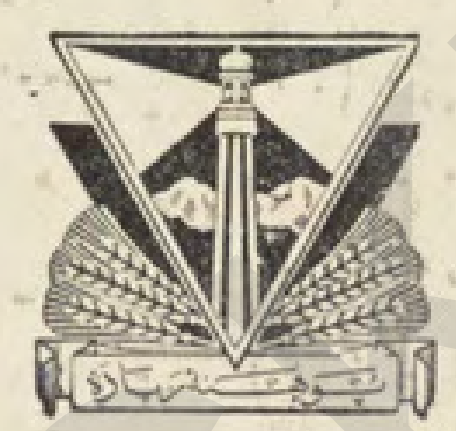

